University of Louisville

ThinkIR: The University of Louisville's Institutional Repository

Electronic Theses and Dissertations

$12-2006$

\title{
Geomorphic considerations for restoration of headwater streams impacted by mountaintop mining hollow fills.
}

Ben Mater 1982-

University of Louisville

Follow this and additional works at: https://ir.library.louisville.edu/etd

\section{Recommended Citation}

Mater, Ben 1982-, "Geomorphic considerations for restoration of headwater streams impacted by mountaintop mining hollow fills." (2006). Electronic Theses and Dissertations. Paper 917. https://doi.org/10.18297/etd/917

This Master's Thesis is brought to you for free and open access by ThinkIR: The University of Louisville's Institutional Repository. It has been accepted for inclusion in Electronic Theses and Dissertations by an authorized administrator of ThinkIR: The University of Louisville's Institutional Repository. This title appears here courtesy of the author, who has retained all other copyrights. For more information, please contact thinkir@louisville.edu. 


\title{
GEOMORPHIC CONSIDERATIONS FOR RESTORATION OF HEADWATER STREAMS IMPACTED BY MOUNTAINTOP MINING HOLLOW FILLS
}

\author{
By \\ Ben Mater \\ B.S., University of Louisville, 2006

\begin{abstract}
A Thesis
Submitted to the Faculty of the University of Louisville

J.B. Speed School of Engineering

in Partial Fulfillment of the Requirements

for the Professional Degree
\end{abstract}

MASTER OF ENGINEERING

Department of Civil and Environmental Engineering

December 2006 



\section{GEOMORPHIC CONSIDERATIONS FOR RESTORATION OF HEADWATER STREAMS IMPACTED BY MOUNTAINTOP MINING HOLLOW FILLS}

Submitted by:

Benjamin D. Mater

A Thesis Approved on

(Date)

by the Following Reading and Examination Committee:

Dr. Arthur C. Parola, Thesis Director

Dr. Mark N. French

Dr. Nageshwar R. Bhaskar

Dr. John S. Usher 


\section{ACKNOWLEDGEMENTS}

I would like to give sincere thanks to Dr. Bhaskar, Dr. French, and Dr. Usher who, without reservation, agreed to serve on my thesis reading committee. Also, special acknowledgement is due to my advisor, Dr. A.C. Parola for exposing me to the newly emerging, exciting field of stream restoration. I never thought that catching crawdads with solo cups in my backyard creek had the potential to evolve into a professional career.

Additional thanks to the Kentucky Division of Mine Permits for supplying critical data and tips on deciphering the language of coal mining permitting. The task of wading through piles of paper work and extracting relevant information would not have been possible without the help of this agency's ever-helpful employees including Mr. Richard Daye, Mrs. Ceci Mitchell, and Ms. Kristin Toth.

Also instrumental to the completion of this thesis was information provided by a University of Louisville Stream Institute investigation evaluating stream restoration techniques in headwaters impacted by hollow fill construction. Thanks to Stream Institute researchers William Vesely and Dr. Michael Croasdaile for their data collection efforts and to the Kentucky Division of Water and U.S. Environmental Protection Agency for funding the Stream Institute project.

To my friends and co-workers at the University of Louisville Stream Institute, I would also like to give thanks for providing valuable information, advice, friendship, and entertainment. Specifically I would like to thank Chandra Hansen for her expert advice 
regarding the nuances of technical writing and Dr. Michael Croasdaile for braving the briars and scorching heat of eastern Kentucky in early August.

Above all, I would like to thank my parents and family who have been unconditionally supportive of me throughout my collegiate career. Without them I may have never been exposed to the subtleties of nature I have grown to love and hope to preserve as a part of my future profession. 


\begin{abstract}
Within the Appalachian hills of eastern Kentucky, large-scale coal mining operations are directly altering the headwater landscape through the construction of hollow fills. These man-made landforms and their associated in-stream structures alter a longterm, continuous morphologic evolution driven by the natural interaction of erosive forces and material of the earth's surface. Post-mining channel morphology, hillslopes, and hollow fills continue to actively evolve in response to erosive forces. Aquatic ecosystem functionality and hollow fill stability may be jeopardized by this condition, yet they may be preserved through efforts to restore or re-create channel morphology more representative of the natural headwater stream. The success of such stream restoration efforts depends largely on the incorporation of geomorphic considerations. A field investigation of select headwaters impacted by hollow fill construction revealed active post-mining morphologic evolution of streams and the interrelated hillslopes driven by discernable geomorphic processes. Through an analysis of longitudinal stream profiles, the current study presents practical geomorphic considerations regarding discrepancies between permitted hollow fill plans and as-built hollow fills. Additionally, pre- and postmining longitudinal profiles are compared to investigate the physical differences that may instigate morphologic evolution. The examined hollow fills were constructed under regulations which pre-date those currently in place; the observations and considerations derived from them, however, will be useful in the development of stream restoration practices in mined areas.
\end{abstract}


TABLE OF CONTENTS

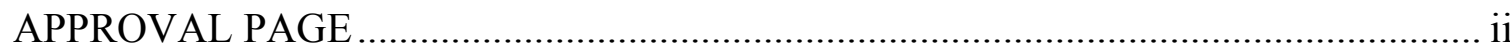

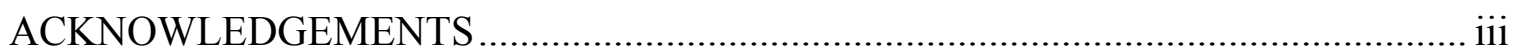

ABSTRACT .

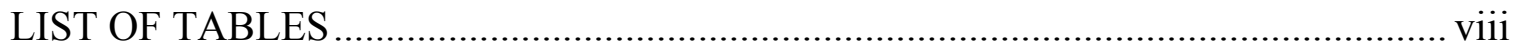

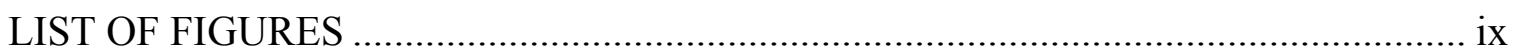

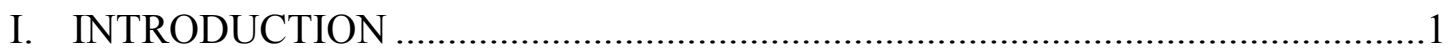

II. BACKGROUND AND LITERATURE REVIEW .............................................

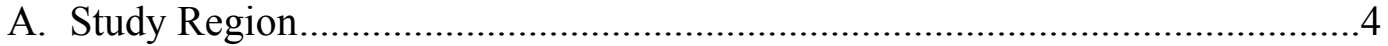

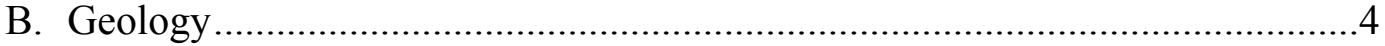

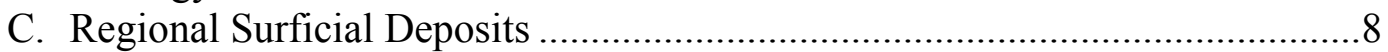

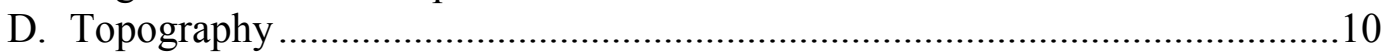

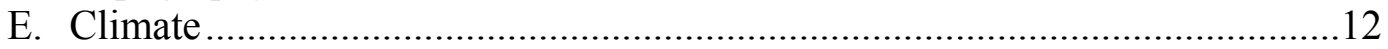

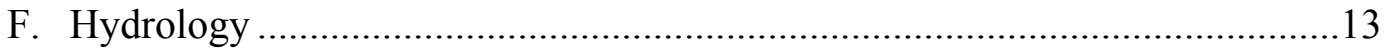

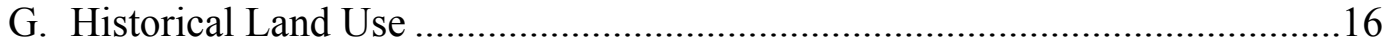

H. Headwater Streams and Their Morphology .................................................18

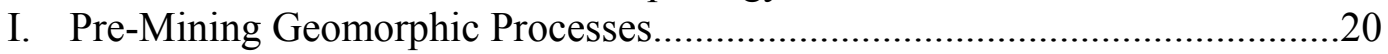

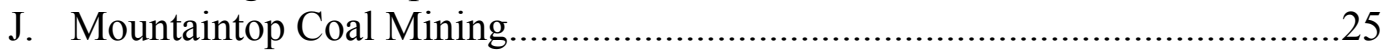

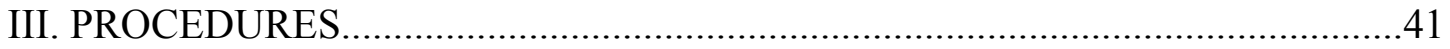

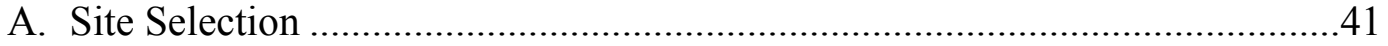

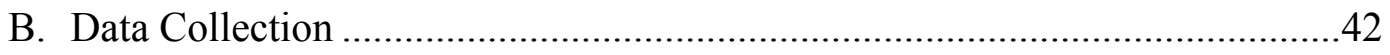

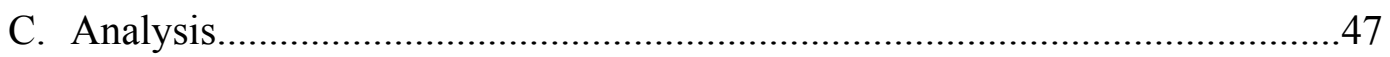

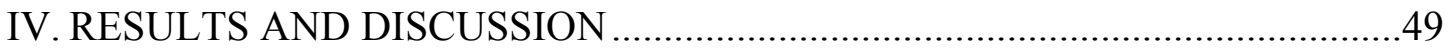

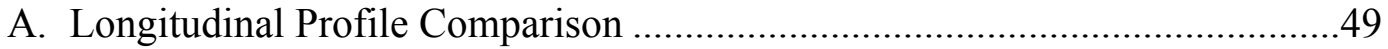

1. As-Built vs. Plan ...........................................................................

2. Post-Mining vs. Pre-Mining Groin Ditch Longitudinal Profiles ................59

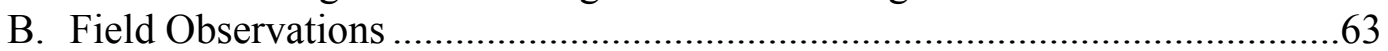

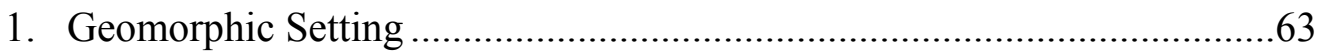

2. Geomorphic Processes .........................................................................

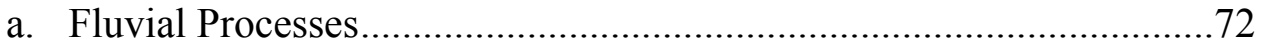

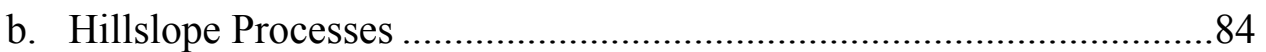

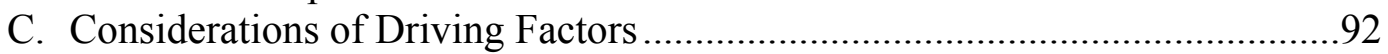

D. Considerations of Observed Processes …………......................................94

1. Fluvial Processes................................................................................

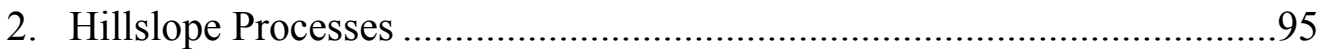

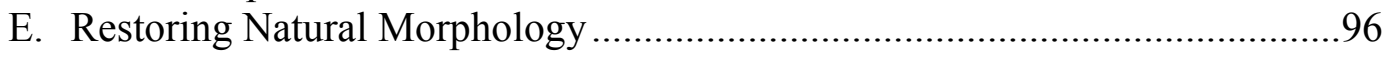

V. CONCLUSIONS AND RECOMMENDATIONS ……………….....................103 


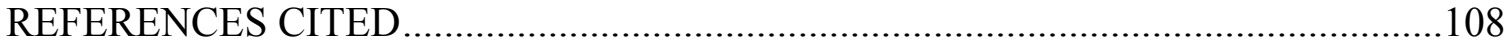

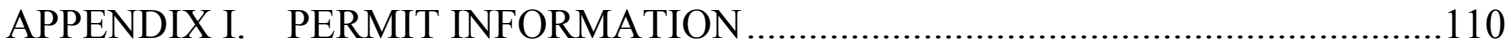

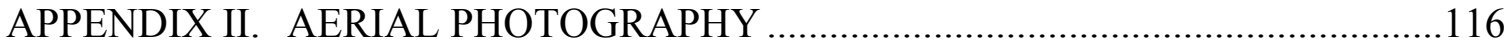

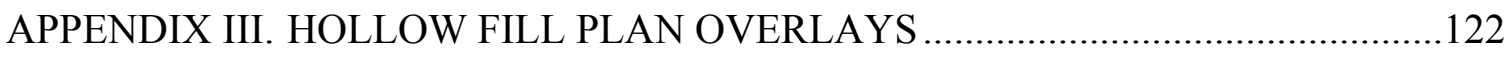

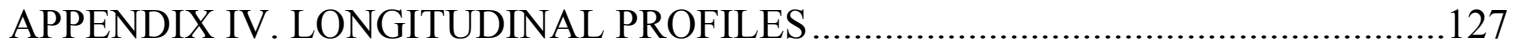

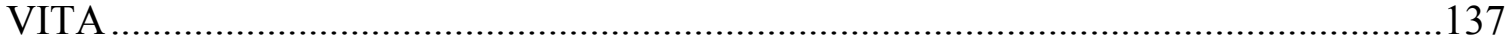




\section{LIST OF TABLES}

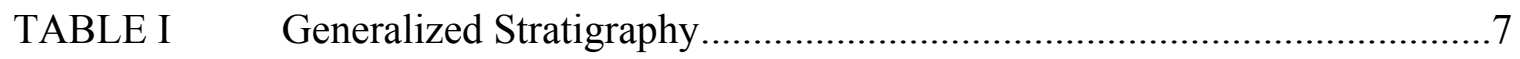

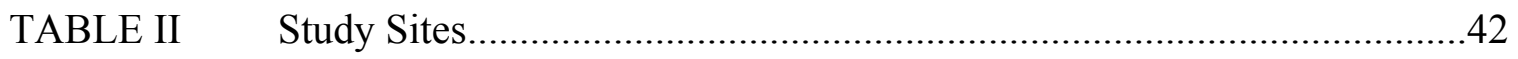

TABLE III Plan and As-Built Groin Ditch Dimensions and Average Slopes............53

TABLE IV Comparison of Approximate Original and Groin Ditch Local Slopes at Hollow Fill Toes ..............................................................................61

TABLE V General Permitting Information ........................................................113

TABLE VI Hollow Fill Permitting Information ..................................................114

TABLE VII Hollow Fill Drainage Areas .........................................................115 


\section{LIST OF FIGURES}

FIGURE 1 Physiographic Regions of Kentucky .................................................

FIGURE 2 Idealized Appalachian Groundwater Flow

(Ward and Wilmoth modified by Hobba, 1987, p. 157) ..........................15

FIGURE 3 Typical Sinuous Highwall Cut of Contour Mining Operation

(Carr, 1999, as displayed in USEPA, 2003) .26

FIGURE 4 Typical Area Mining Operation (Arch Coal, Inc., 1999, modified and displayed by USEPA, 2003, p. III.I-19).................................................27

FIGURE 5 End-dumping During Construction of a Durable Rock Fill (Arch Coal, Inc., 1999, as displayed in USEPA, 2003, p. III.K-7)...........30

FIGURE 6 Observed Durable Rock Fill in Construction near Study Sites.................30

FIGURE 7 Durable Rock Fill after Completion of Construction (Arch Coal, Inc., 1999, as displayed in USEPA, 2003, p. III.K-7)...........31

FIGURE 8 Permitted Design Plans of HF 11 from Permit No. 898-0349 Displaying Typical Durable Rock Fill Configuration and Surface (Groin Ditches) and Subsurface (Underdrain) Drainage ...........................32

FIGURE 9 Permitted Profile View of HF 11 from Permit No. 898-0349...................33

FIGURE 10 Permitted Cross Section at Crest of HF 11 from Permit No. 898-0349...33

FIGURE 11 Detail of Typical Durable Rock Fill Terrace Bench from Permit No. 898-0349 .34

FIGURE 12 Detail of Typical Groin Ditch Cross Section from Permit No. 898-0349 .35

FIGURE 13 Design Calculations for Sizing a Groin Ditch of HF 4 from Permit

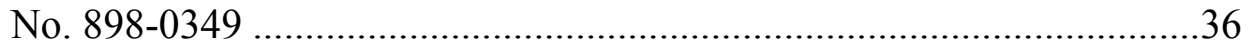

FIGURE 14 Detail Underdrain Cross Section from Permit No. 898-0349 ...................37

FIGURE 15 Design Drawing of Rock Check Dam at Toe of a Hollow Fill from Permit No. 897-0365 ..........................................................................

FIGURE 16 Rock Check Dam at HF 1 from Permit No. 898-0349..............................39

FIGURE 17 Design Drawing of a Sediment Pond and Embankment Downstream of HF 11 on Permit No. 898-0349

FIGURE 18 Sediment Pond Below HF 1 and HF 2 During Time of Use (Prior to Field Visit) 40

FIGURE 19 Map of Study Hollow Fill Locations: Permit No. 898-0349 
FIGURE 20 Map of Study Hollow Fill Locations: Permit No. 897-0365 ..................44

FIGURE 21 Hollow Fills Arches 1 and Arches 2 (Permit No. 897-0365)..................45

FIGURE 22 Overlay of Permitted Hollow Fill Design Plans for HF 11 onto Aerial Photograph ....................................................................................51

FIGURE 23 Comparative Plot of As-Built and Plan Longitudinal Profiles and Slopes for the East Groin Ditch on HF 11 ........................................52

FIGURE 24 Local Slopes of (a) Plan and (b) As-Built Groin Ditch Profiles ..............55

FIGURE 25 Comparison of Local Slopes for As-Built and Plan Groin Ditch Profiles

FIGURE 26 Correlation of Error in Measured As-Built Local Slopes (Percent

Difference from Actual Surveyed) with Measured As-Built Local Slopes....

FIGURE 27 Comparative Plot of Pre-Mining Headwater Stream and Groin Ditch Longitudinal Profiles for Arches 1.....................................................60

FIGURE 28 Typical Surveyed Groin Ditch Cross Section (HF 11) .........................64

FIGURE 29 Typical Boulder Substrate Lining Groin Ditches (HF 10 on Permit No. 898-0349)

FIGURE 30 Interstitial Spaces of Groin Ditch Lining Filled with Products of Weathering Rock (HF 10 on Permit No. 898-0349) ..............................65

FIGURE 31 Typical Rock Check Dam Structure (Arches 2) ....................................66

FIGURE 32 Extent of Post-Mining Longitudinal Stream Survey for HF 10 .............67

FIGURE 33 Reclaimed Sediment Pond Area (HF 11).......................................67

FIGURE 34 Channel Morphology for Stream Reaches Adjacent to but Not Directly Altered by Constructed Structures; Evidence of (a) Fluvial Organization and (b) Forced Deposition of Sediment Downstream of HF 11 (a) and HF 4 (b).

FIGURE 35 Surveyed Longitudinal Stream Profile Revealing Knickpoint Created by Former Sediment Pond Embankment and Impounded Wedge of Sediment (HF 11)

FIGURE 36 Surveyed Longitudinal Stream Profile Revealing Knickpoints Created by a Supplementary Sediment Pond and Rock Check Dam (HF 11) ......73

FIGURE 37 (a) 3-Dimensional, (b) Cross-Sectional, and (c) Longitudinal Views of Typical Channel Evolution after the Removal of a Small Dam (Doyle et al., 2003); Stages C or D are Similar to Observations at Reclaimed Sediment Ponds. 
FIGURE 38 (a) A Dramatic Example of a Vertical Headcut at Sediment Pond Downstream of HF 4 and HF 9: Headcut Represented by an Approximately 10-foot Vertical Face; (b) Vertical Face of Headcut in Material of Supplementary Sediment Pond (HF 11)

FIGURE 39 Reconstructed Channels on Sediment Pond Embankments

Downstream of (a) HF 11 and (b) HF 2 .78

FIGURE 40 Evidence of Mass Wasting and Bank Instability during Bed

Degradation of Reconstructed Stream Reach Across Reclaimed

Sediment Pond Area (HF 10)

FIGURE 41 High, Actively Eroding Bank Flanking Rock Check Dam Indicating

Bed Degradation Possibly After the Initiation and Passage of a Headcut (HF 11); (a) Perspective View, (b) Close-up View .80

FIGURE 42 Unstable Banks and Displaced Rip-Rap Indicating Failure of Large Rip-Rap Armoring to Prevent Bed Degradation at a Reconstructed Reach Across a Reclaimed Sediment Pond Area (HF 10).

FIGURE 43 Evidence of Undermining and Bank Instability Along Groin Ditches of (a) HF 2 and (b) HF 10 .83

FIGURE 44 Fine-Grained Sediment Deposit at Low-Gradient Reach of Reclaimed Sediment Pond Area Looking (a) Upstream and (b) Downstream from Head of Reconstructed Channel (HF 11)

FIGURE 45 (a) Newly Evolving Morphology at Head of Reclaimed Sediment Pond Resembling Wetlands and (b) a Small Meandering Channel Looking Downstream (HF 4,HF 9); Note That Figure 45a Represents the Morphology of Figure 44a Looking Upstream After the Passage of Approximately 3 Years....

FIGURE 46 Disturbed and Displaced Debris Indicating a Recent Landslide on a Hillside Adjacent to HF 11

FIGURE 47 Slope Debris (Soil and Rock) Introduced to the Adjacent Groin Ditch as a Result of the Landslide Indicated in Figure 46. .88

FIGURE 48 Evidence of Rill Erosion on a Backfilled Slope Adjacent to HF 11

FIGURE 49 (a) Avulsion from Groin Ditch Channel of Arches 2 and (b) Local Depression Capable of Supporting Cattails on HF 11, Indicating Possible Differential Fill Settlement.

FIGURE 50 Weathering Shale Boulder Lining a Groin Ditch of HF 2 and Slaking to Produce Fluvially-Mobile Sediment. 
FIGURE 51 Comparison of (a) Colluvial and (b) Groin Ditch Morphologies;

(a) Represents a Stream Within the Lilley Cornett Woods of Letcher County, Kentucky, at a Drainage Area of Approximately 19 Acres and an Approximate Slope of 30\%, Both Measurements Similar to Those of the Downstream Section of the Groin Ditch of a Hollow Fill Near Study Sites (Permit No. 898-0349)

FIGURE 52 (a) Drainage Area vs. Reach Slope for Channels in a Washington State Watershed; the Inflection Between Colluvial and Alluvial Morphologies may Reflect a Difference in Geomorphic Processes; (b) Idealized Longitudinal Profile from Hillslopes and Unchanneled Hollows Downslope through the Channel Network Showing the General Spatial Variation of Channel Types and Controls on Channel Processes in Mountain Streams (from Montgomery and Buffington, 1997, pp. 603-604)

FIGURE 53 Comparison of (a) Plane-Bed and (b) Reconstructed Channel Morphology (Looking Upstream) Observed Directly Downstream (a) and Across (b) the Reclaimed Sediment Pond of HF 11 .... 102

FIGURE 54 Aerial Photograph of HF 1 and HF 2 (Permit No. 898-0349) 117

FIGURE 55 Aerial Photograph of HF 5 (Permit No. 898-0349) ..............................118

FIGURE 56 Aerial Photograph of HF 4, 9, and 10 (Permit No. 898-0349)..............119

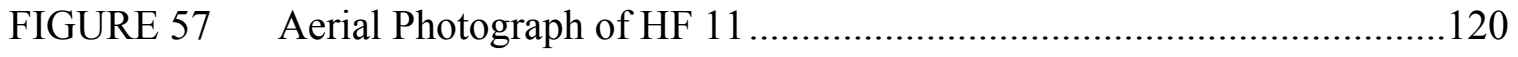

FIGURE 58 Aerial Photograph of Arches 1 and Arches 2 (Permit No. 897-0365) ...121

FIGURE 59 Permitted Hollow Fill Design Plans Overlain onto Aerial Photography: (a) HF 1; (b) HF 2

FIGURE 60 Permitted Hollow Fill Design Plans Overlain onto Aerial

Photography: (a) HF 4; (b) HF 5

FIGURE 61 Permitted Hollow Fill Design Plans Overlain onto Aerial Photography: (a) HF 9; (b) HF 10.

FIGURE 62 Permitted Hollow Fill Design Plans Overlain onto Aerial Photography: (a) Arches 1; (b) Arches 2

FIGURE 63 Comparison of Plan and As-Built Longitudinal Groin Ditch Profiles for the East Groin Ditch of HF 1

FIGURE 64 Comparison of Plan and As-Built Longitudinal Groin Ditch Profiles for the East Groin Ditch of HF 2 ...................................................... 128

FIGURE 65 Comparison of Plan and As-Built Longitudinal Groin Ditch Profiles for the West Groin Ditch of HF 4

FIGURE 66 Comparison of Plan and As-Built Longitudinal Groin Ditch Profiles for (a) North and (b) South Groin Ditches of HF 5 
FIGURE 67 Comparison of Plan and As-Built Longitudinal Groin Ditch Profiles for (a) North and (b) South Groin Ditches of HF 9

FIGURE 68 Comparison of Plan and As-Built Longitudinal Groin Ditch Profiles for (a) North and (b) South Groin Ditches of HF 10

FIGURE 69 Comparison of Plan and As-Built Groin Ditch and Pre-Mining Stream Longitudinal Profiles for (a) East and (b) West Groin Ditches of HF 11

FIGURE 70 Comparison of Plan and As-Built Longitudinal Groin Ditch Profiles for (a) North and (b) South Groin Ditches of Arches 1

FIGURE 71 Comparison of Plan and As-Built Longitudinal Groin Ditch Profiles for (a) North and (b) South Groin Ditches of Arches 2 .........................135

FIGURE 72 Extent of Post-Mining Longitudinal Stream Survey for HF 11 ..............136

FIGURE 73 Typical Flow Regime Hydrology of an Appalachian Headwater Stream; Longitudinal Profile from Narrows Branch of Blackberry Fork 


\section{INTRODUCTION}

Due to Americans' ever-increasing energy demands and technological advances in mining equipment, forms of mountaintop coal mining involving drastic topographic alteration have emerged in the Appalachian hills of eastern Kentucky. While of improved economic efficiency, such techniques often involve the removal of large portions of hilltops in an effort to expose the region's seams of highly valued, clean-burning, lowsulfur coal. After large-scale blasting and excavation have been utilized to expose coal seams, the overburden that formerly existed as overlying rock is deposited in adjacent or proximal valley heads as constructed fills. Such valley fills (also known as hollow fills in Kentucky) effectively bury the upstream-most, or headwater, reaches of streams.

These headwater streams and the interacting hillsides represent a physical environment governed by the interaction between characteristic erosional forces and the material on which they act. Various geomorphic processes constitute this reaction and are responsible for a continual evolution of the headwater landscape. Due to the affiliation of many geomorphic processes with flowing water, this evolution is manifested most lucidly by changing headwater stream morphology. Mountaintop mining and hollow fill construction may alter the rate and nature of morphologic evolution by altering stream flow or channel substrate or by directly changing the channel morphology itself. Consequently, the newly evolving post-mining stream morphology may not support the premining aquatic ecosystem. Additionally, hollow fills, representing man-made landforms responsive to changes in stream morphology, may similarly evolve in such a way that they present a hazard to the surrounding ecosystem and human community. Current 
mining reclamation practices lessen the severity of these consequences, yet may be augmented by further actions to re-create or restore impacted streams that consider altered substrate, streamflow, morphology, and most importantly, geomorphic processes. At present, such further efforts may be hindered by an incomplete understanding of postmining geomorphic processes.

The potential for stream restoration and the current knowledge gap are explicitly mentioned in the recent Draft Programmatic Environmental Impact Statement (USEPA, 2003) compiled by the U.S. Army Corps of Engineers (COE), the U.S. Environmental Protection Agency (EPA), the U.S. Department of Interior's Office of Surface Mining (OSM) and Fish and Wildlife Service (FWS), and the West Virginia Department of Environmental Protection (WVDEP): "Due to the current lack of data to support creation of viable streams on mining operations, studies exploring the amount of, or possibility for, creation of streams should be considered" (p. III.D-2). The interagency DEIS draws upon data collected by various studies and largely represents the state of knowledge regarding general aspects of the environment impacted by mountaintop mining and hollow fill construction. Of the various studies represented, only the USGS investigation performed by Wiley et al. (2001) specifically addresses geomorphic processes extant within headwater streams impacted by hollow fills. General findings of this investigation indicated an appreciable increase in fine sediment and little change in channel morphology of streams downstream of filled valleys. The geomorphic investigation of Wiley et al., however, makes no mention of geomorphic processes or morphologic changes occurring within the uppermost, directly impacted headwater stream reaches. To 
the understanding of the author, no published reports exist regarding the impact of mining and hollow fill construction on the geomorphic processes within these specific reaches.

The purpose of this study is to improve the geomorphic knowledge base necessary for the preservation of hollow fill stability and the re-creation and restoration of ecologically viable streams on and directly downstream of hollow fills associated with mountaintop coal mining operations. Specific objectives in the achievement of this purpose include (1) an analysis of longitudinal stream profile data, (2) field observation of geomorphic processes occurring in the presence of hollow fills, and (3) the development of considerations necessary to the success of future headwater stream re-creation or restoration efforts.

Longitudinal stream profile data from approved mining permits, aerial photography, USGS topographic maps, and previously collected field survey data were analyzed for geomorphically relevant aspects that may be of concern to stream restoration efforts. The analysis of post-fill processes was performed with the primary aid of data acquired through field visits and literature review. The examined hollow fills were constructed under regulations which pre-date those currently in place; the observations and considerations derived from them may be useful, however, in the development of stream restoration practices in mined areas. The relevance of post-mining geomorphic processes to stream ecology or hollow fill stability is also provided. 


\section{BACKGROUND AND LITERATURE REVIEW}

\section{A. Study Region}

The Eastern Kentucky Coal Field physiographic region of Kentucky (Figure 1) is associated with mountaintop mining operations and encompasses the headwater streams investigated as part of the current study. This region falls within the widespread Appalachian Plateaus province, which spans not only eastern Kentucky, but portions of West Virginia, Virginia, and Tennessee. The Eastern Kentucky Coal Field is characterized by steeply sloping, sinuous terrain and narrow valleys dissected by dendritic streams (Davis, 1924). The major rivers draining the area are the Kentucky, Licking, Big Sandy, and Cumberland. The water of these drainage systems and the geology over which it flows have served to sculpt the region's landforms. Factors that continue to affect geomorphic processes acting within the region's headwater stream systems include regional geology and surficial deposits, topography, climate, hydrology, and land use.

\section{B. Geology}

Through tectonic uplifting, denudation, and deposition, geomorphic processes sculpt the surface of the earth into a vast array of landforms. The geologic formations most often subjected to geomorphic processes within the Eastern Kentucky Coal Field are flat-lying clastic rocks deposited during the Pennsylvanian period 250-300 million years ago. During this time sediment eroding from the ancestral Appalachian mountains was 


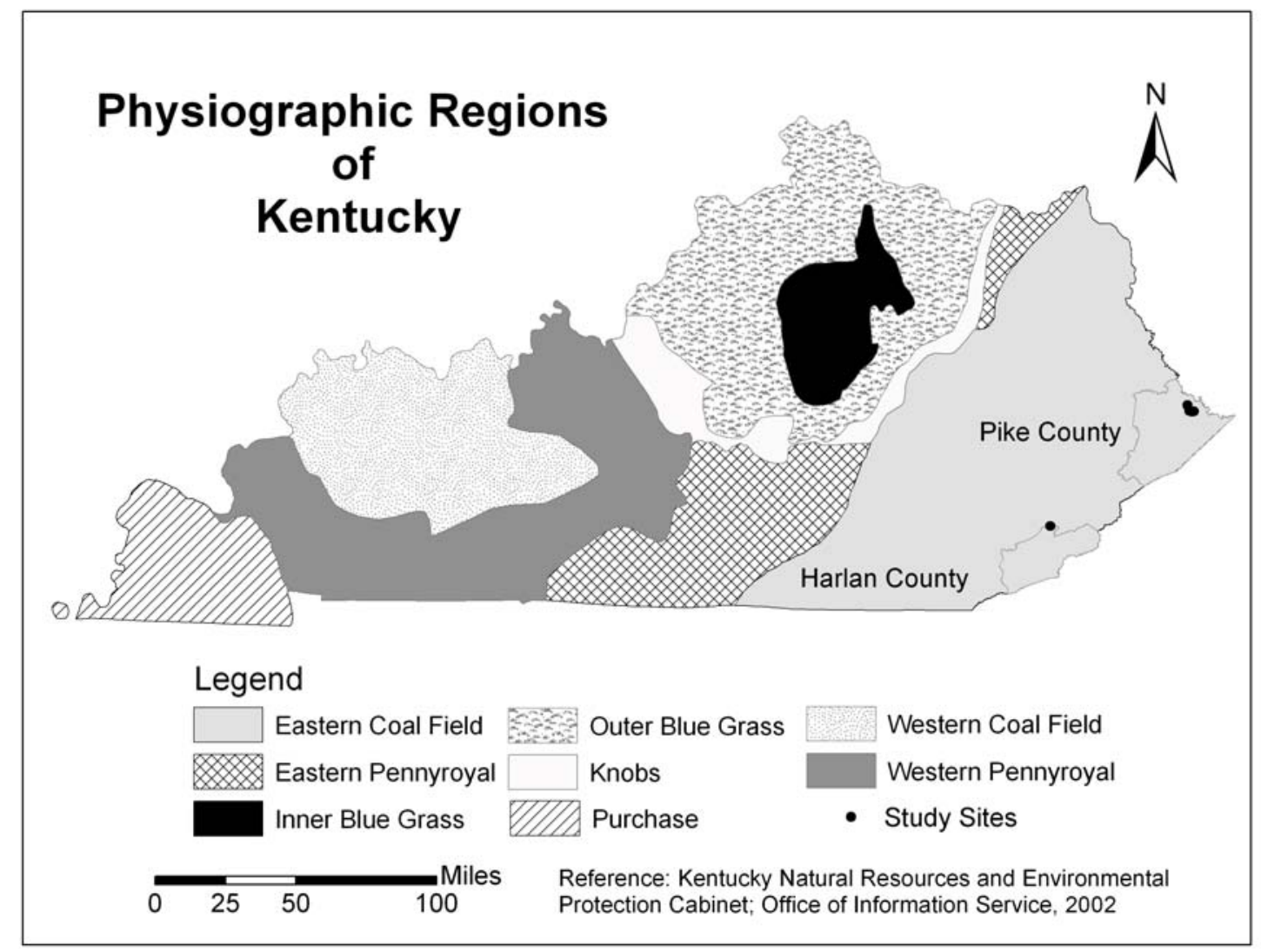

FIGURE 1- Physiographic Regions of Kentucky

deposited in a large inland sea extending over a region known as the Appalachian basin. Fluctuations in the level of this ancient sea, along with basin subsidence and changes in depositional environment, resulted in a cyclical layering of the region's coal-bearing lithology. Comprised of predominantly interbedded sandstone, shale, coal, and to a lesser extent, limestone, these repeated sequences of lithology are known as cyclothems (Brady et al., as cited in USEPA, 2003).

The region's low-sulfur coal, which is the target of mining operations, owes its properties to the environmental conditions under which its predecessor, peat, was deposited and decayed. The vegetation from which this peat evolved inhabited swampy regions bordering the inland sea of the Appalachian basin. Such areas were divided into 
fluvial or deltaic depositional environments which, along with the influences of subsidence, governed the quality and nature of the resulting coal deposits (Horne et al., 1978). The lateral extent of these deposits may be attributed to the migration of coastal swamps as sea levels fluctuated (USEPA, 2003).

Erosion of the Appalachian mountain precursors continued into and throughout the Mesozoic era, wearing the early mountains down to nearly level plains. Present day topography was established only after regional uplifting and rejuvenation of erosion during the Cenozoic era (USEPA, 2003). Due to relatively little deformation of the original layered lithology, the hills of the Eastern Kentucky Coal Field are a highly dissected upland plateau (Outerbridge, 1987).

The Pennsylvanian stratigraphy of the Eastern Kentucky Coal Field includes the Breathitt and Lee formations. Orthoquartzitic sandstone, possibly deposited as channel fills or sandbars is the primary constituent of the older Lee formation (Rice et al. and Horne et al., as cited in Outerbridge, 1987). The erosion-resistant quality of this rock type is responsible for its presence in prominent cliff outcroppings and river knickpoints. Additionally, this resistant rock generally provides stable terrain (Outerbridge, 1987). Overlying the Lee formation is the Breathitt formation consisting of less resistant subgraywacke sandstone interbedded with siltstone, shale, and coal. The Breathitt formation is of significance to this study due to its multiple coal beds that are the target of most mining operations. The relatively greater thickness and higher elevation of this formation also contribute to its significance as a subject of geomorphic processes. Table I represents the typical stratigraphy of the region provided by the US Geological Survey (USGS) as presented by Outerbridge (1987). 


\section{TABLE I}

\section{GENERALIZED STRATIGRAPHY}

\begin{tabular}{|c|c|c|c|c|}
\hline System & Series & Formation & Facies & Description \\
\hline \multirow{5}{*}{ 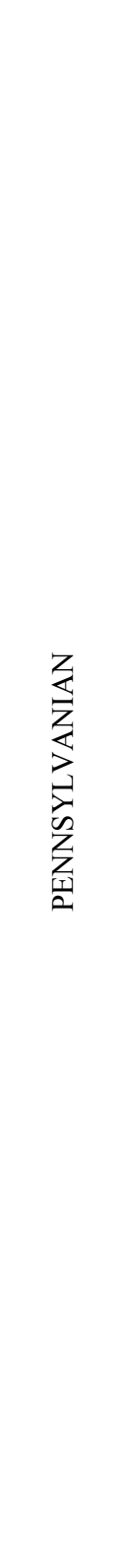 } & \multirow{5}{*}{ 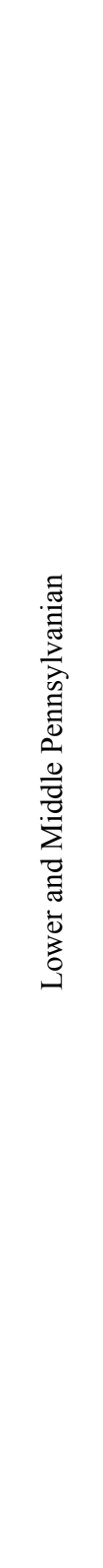 } & \multirow{4}{*}{ 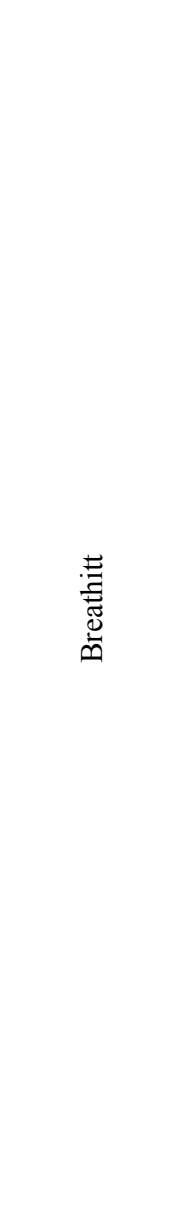 } & \multirow{2}{*}{ 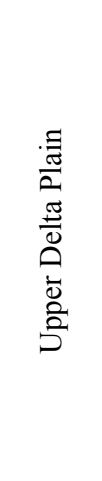 } & $\begin{array}{l}\text { Sandstone, siltstone, shale, and coal; sandstone, gray, weathers } \\
\text { yellowish-brown, in locally large channel-fill deposits, interbedded with } \\
\text { siltstone and shale; siltstone and shale, gray, weathers green to } \\
\text { yellowish-brown; coal beds generally less than } 1 \mathrm{~m} \text { thick. Forms } \\
\text { rounded to craggy hills with rockfalls and abundant debris flows and } \\
\text { avalanches. }\end{array}$ \\
\hline & & & & $\begin{array}{l}\text { Sandstone, siltstone, shale, and coal; sandstone, gray, weathers } \\
\text { yellowish-brown, commonly in large channel-fill deposits which } \\
\text { contain quartz-pebble conglomerate interbedded with siltstone and } \\
\text { shale; siltstone and shale, medium-dark-gray weathers yellowish- } \\
\text { brown; coal beds as much as } 6 \text { m thick. Forms very steep craggy hills } \\
\text { with rockfalls and abundant debris flows and avalanches }\end{array}$ \\
\hline & & & 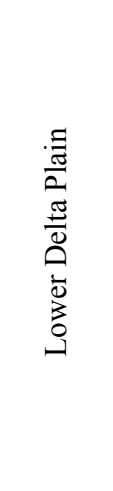 & $\begin{array}{l}\text { Sandstone, siltstone, shale, and coal; sandstone, gray, weathers } \\
\text { yellowish-brown, commonly in channel-fill deposits, interbedded with } \\
\text { siltstone and shale; siltstone and shale, medium-dark gray, weather } \\
\text { yellowish-brown; coal beds generally less than } 3 \mathrm{~m} \text { thick. Forms steep } \\
\text { craggy hills with rockfalls and abundant debris flows and debris } \\
\text { avalanches. } \\
\text { Thin limestone beds occur throughout the stratigraphic column above } \\
\text { the top of the Lee Formation but aggregate less than } 1 \text { percent of the } \\
\text { column; gray to black, weather gray; these rocks have no effect on } \\
\text { topography or landslides. } \\
\text { Orthoquartzites of the Lee Formation intertongue with adjacent } \\
\text { formations. }\end{array}$ \\
\hline & & & 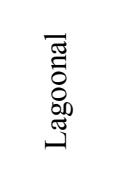 & $\begin{array}{l}\text { Siltstone, shale, sandstone, and coal; siltstone and shale, dark-gray, } \\
\text { weathers yellowish-brown, in units up to } 20 \mathrm{~m} \text { thick, commonly } \\
\text { interbedded with sandstone laminae; sandstone, gray, weathers } \\
\text { yellowish-brown, also in local channel fills; coal beds generally less tan } \\
2 \mathrm{~m} \text { thick. Forms rounded hills with debris flows and debris avalanches. }\end{array}$ \\
\hline & & $\underset{\Xi}{\stackrel{\Xi}{\leftrightarrows}}$ & 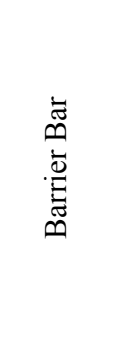 & $\begin{array}{l}\text { Sandstone, conglomerate, siltstone, shale, and coal; sandstone } \\
\text { orthoquartzitic, light-gray to white, weather white to pink to brown, in } \\
\text { thick channel-fill-like deposits commonly with basal quartz-pebble } \\
\text { conglomerate as much as } 3 \mathrm{~m} \text { thick; interbedded with dark-gray } \\
\text { siltstone and shale that weathers yellowish-brown; coal beds generally } \\
\text { less than } 2 \mathrm{~m} \text { thick. Sandstone forms cliffs, as much as } 90 \mathrm{~m} \text { thick and } \\
\text { mesas. Forms generally stable terrain and stabilizes overlying beds } \\
\text { except at cliffs where rockfalls litter slopes below with boulders up to } \\
\text { about } 10 \mathrm{~m} \text { across. }\end{array}$ \\
\hline 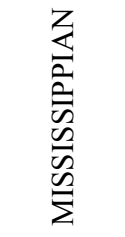 & 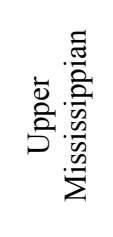 & 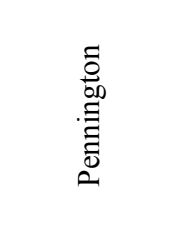 & 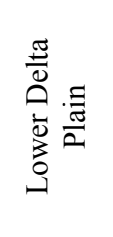 & $\begin{array}{l}\text { Sandstone, siltstone, shale, and limestone; sandstone, reddish-gray to } \\
\text { gray, weathers yellowish-brown to red, in channel fills, interbedded } \\
\text { with siltstone and shale; siltstone and shale, reddish-gray, weathers } \\
\text { yellowish-brown to red, with interbedded thin gray, yellow-weathering } \\
\text { limestone beds. Forms very abundant earth flows and debris flows. }\end{array}$ \\
\hline
\end{tabular}


With the exception of the Pine Mountain thrust fault, the structure of the region's geology remains in a relatively undisturbed state of limited dip, faults, or folding. Unlike the Valley and Ridge province to the east, the Appalachian basin region was spared the rock warping forces induced by continental collisions during the formation of Pangea. The flat-lying structure is only mildly deformed into a broad shallow syncline spanning eastern Kentucky, southern West Virginia, Virginia, and Tennessee. Rocks dip gradually with existing localized anticlines. In addition to these slight deformations, the geological structure of the Eastern Kentucky Coal Field includes abundant stress relief joints. As erosion dissects the uplifted Appalachian plateau, large amounts of sediment are removed from underlying rock. The newly exposed rock is relieved of the confining pressure of its overburden and subsequently expands. Due to the low tensile strength of rock, a network of stress relief joints form. This network consists of vertical joints along valley walls and horizontal joints between bedding planes along valley floors. The interconnectedness of these joints provides a significant conduit for groundwater flow (Wyrick and Borchers, as cited in Outerbridge, 1987) and reflects an inherent interrelationship between geomorphic forces, geology, and hydrology.

\section{C. $\underline{\text { Regional Surficial Deposits }}$}

The forces of weathering are in constant action against bedrock. The gradual loss of structural rock integrity due to such sources produces residual loose rock and soil on the land surface that lends itself to deformation and transportation brought on by geomorphic processes. Surficial deposits may be grouped into three categories based on the geomorphic process responsible for their origin or deposition: residuum, colluvium, and alluvium. These processes vary from hilltop to stream channel with those responsible 
for the production of residuum predominantly occupying the uppermost elevations of this spectrum. Weathering of bedrock geology on hilltops and along ridge crests produces inplace deposits of residual materials. The depth of weathering and the resulting residuum is often dependent on bedrock permeability. In the Eastern Kentucky Coal Field, low permeable shale layers often limit the infiltration of water which is largely responsible for degradation of rock integrity (Outerbridge, 1987). Residual soils of the region vary from soft clay produced by weathered shale to sandy loam produced by friable sandstone (Outerbridge, 1987; USDA, 1990, 1992). In comparison with colluvium of hillsides and alluvium of valley bottoms, residuum of hilltops and ridges is relatively young, serving as a source of material for other forms of deposits.

Colluvial materials consist of loose debris transported from hilltops and slopes under the influence of gravity and water. Deposits of this unconsolidated material cover all but the steepest hillsides of the region, thickening and coarsening in the down-slope direction due to natural sorting by gravity and increasing contributing drainage area (Outerbridge, 1987; Hack and Goodlett, 1960). Soils produced through the weathering of colluvium are deep sandy or loamy soils with varying amounts of rock fragments (USDA, 1990, 1992). Accumulation of colluvium and the soils it parents may induce sudden mass movement events and creep on steep hillslopes (Hack and Goodlett, 1960).

Although sparse or non-existent in headwater channels, alluvium constitutes the third form of surficial deposit. Such deposits accumulate as sediment originating from upland areas is transported and deposited through fluvial action to form stream floodplains and terraces. The Eastern Kentucky Coal Field's deep, well-drained loamy and sandy soils are a product of weathered alluvial deposits (USDA, 1990, 1992). 


\section{Topography}

The geology and surficial deposits of the Eastern Kentucky Coal Field respond characteristically to imposed geomorphic processes to produce the landforms of the region. Based on the response of bedrock to geomorphic processes, Outerbridge's (1987) physiographic delineation of the Appalachian Plateaus province describes the topography of the study region as characterized by narrow and sinuous ridges and valleys. Geomorphic processes extant within the region have heavily dissected the flat-lying beds of Breathitt geology with dendritically patterned streams that remove sediment from the forming landscape of headwater regions. The resulting topography more truly represents a dissected plateau than a mountain range resulting from differential tectonic uplift and geologic deformation. In comparison with true and geologically youthful mountain ranges, the Appalachian hills of Kentucky are typically of less relief. However, at the scale of the first-order basin, which is frequently impacted by hollow filling, the classification retains relevance.

Topography specific to headwater regions may be presented in the form of a subdivided first-order valley. As presented by Hack and Goodlett (1960) in a study focused in the Valley and Ridge province of the central Appalachians, the topography of valleys containing first-order streams may be subdivided based on slope and its effect on the downslope movement of water. Variations may exist between Hack and Goodlett's topographic characteristics and those generally found in eastern Kentucky. Such discrepancies may be present due to the fact that the topography studied by Hack and Goodlett has been influenced by significant geologic deformation and is therefore more representative of true mountains than the dissected plateau topography of eastern Kentucky. 
Hack and Goodlett's four-to-five topographically distinct slope areas include nose, side slope, hollow, channelway, and the possibly present foot slope. Each topographic unit is described as follows:

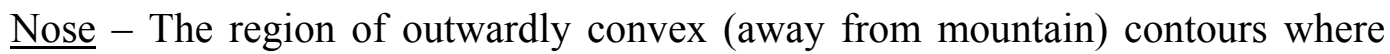
runoff is proportional to a function of the radius of curvature of the contours. This is the driest area of the valley with divergent flow paths and a lack of channelways.

Side slope - The region downhill of the nose where contours are straight and runoff is proportional to a linear function of slope length (assuming no channelways or infiltration).

$\underline{\text { Hollow }}$ - The region of outwardly concave contours where runoff is proportional to a power function of slope length. The channel head is contained within this region of the valley.

Channelway - This region consists of the stream channel itself and is characterized by a narrow strip of sharp, outwardly concave contours with runoff proportional to a power function of channel length.

Foot slope - This region represents an area of outwardly concave contours bordering the channel way and downstream of the hollow. The slope of the foot slope is gentler than that of the side slope. This area was found to be not always present as Hack and Goodlett found that the side slope commonly abuts directly on the channel.

This classification reflects the concentrating or diffusing effects of headwater topography on runoff or seepage behavior. Geomorphic processes related to slope stability are heavily influenced by this behavior. 


\section{E. Climate}

The temperate climate of the study region is characterized by warm, humid summers and moderately cold winters (USEPA, 2003). Normal annual precipitation falls within the range of 40 to 50 inches (NOAA, 2005). The hilly relief of the region influences localized temperatures and rainfall (USDA, 1990, 1992).

Climate heavily governs geomorphic processes through its effect on weathering and water supply in the hydrologic cycle. An example of the correlation between climate and geomorphic processes is the phenomenon of asymmetric valleys investigated by Hack and Goodlett (1960). The directional trend in prevailing weather patterns results in slopes of different moisture conditions. Moisture-driven geomorphic processes were found to vary with these localized climatic conditions as evident in the asymmetric valleys they had formed. Slopes with elevated moisture conditions were found to be steep and governed by creep, while drier slopes were found to be gentler and governed by slope wash and rill erosion. Assuming an unvarying influence of geology, this provides one of many examples in which climate may influence geomorphic processes.

Geomorphic dependence on climate is also generated indirectly through weathering rates. Along with subdued topography, the climate of the study region controls the growth of soil-retaining vegetation. The soil retained by this vegetation may increase infiltration and subsequent groundwater flow, thereby accelerating weathering. As previously discussed, increased weathering would result in the creation of greater volumes of surficial deposits susceptible to movement by geomorphic processes (USDA, 1990). 


\section{F. Hydrology}

Water provides the primary driving force necessary for the sculpting of landforms through direct sediment entrainment or simply its non-lotic presence (Leopold et al., 1992). Groundwater and its interaction with area geology are particularly important to flow-dependent geomorphic processes because surface- and groundwater interaction directly affects flow regime. In the Eastern Kentucky Coal Field, the uppermost reaches of most headwater streams are characterized by an ephemeral flow regime. Within this zone, stream flow is entirely dependent on storm water runoff and is completely without a baseflow component provided by effluent groundwater (Ponce, 1984).

Proceeding in the downstream direction, flow regime transitions from ephemeral to intermittent. Although varying legal definitions exist (see, for example, USEPA, 2003, Appendix B), intermittent stream reaches are often considered to be those that flow only certain times of the year in response to both storm runoff and groundwater. The transition from ephemeral to intermittent flow regime occurs at the intersection of the stream channel with the maximum groundwater table elevation. This transition point varies with long-term fluctuations in ground water levels (Ponce, 1984).

The sporadic presence of groundwater baseflow in intermittent reaches becomes continuous at the transition to a perennial flow regime. Streams with perennial flow have a constant contribution of flow from effluent groundwater throughout the year (Ponce, 1984). The transition from intermittent to perennial flow regimes may be considered to be the lowest elevation at which the groundwater table intersects the stream channel throughout the course of seasonal fluctuations. 
A recent study by Paybins (2003) identified transition points between flow regimes in a mountaintop coal mining region of southern West Virginia. The transition points were then compared to drainage areas giving widely varying results and only weak correlation. The variance of the study results were attributed to "local climatic and drainage basin conditions at a first-order stream scale" (Paybins, 2003, p. 18). A specific drainage basin condition mentioned in the study was basin stratigraphy, which directly affects the nature of groundwater flow.

Groundwater flow within the region considered by Paybins is similar to that of the Eastern Kentucky Coal Field due to related rock types and structure. The primary conduit of groundwater flow is the intersecting network of horizontal and vertical stress relief fractures. This secondary form of porosity is accompanied by primary porosity in the form of the hydraulic conductivity of the rocks themselves. The influence of fractured horizontal rock layers of different conductivity on groundwater flow may be seen in the variation of flow regime transition points. For example, relatively permeable sandstone underlain by a shale layer aquitard may produce a point of groundwater effluence where the stratigraphic interface intersects the ground surface. Stress relief or similar fractures further complicate this concept by providing breaks in relatively impermeable rock layers. Figure 2 displays a schematic, as presented by Ward and Wilmoth and modified by Hobba (1987), of groundwater flow through semi-perched and perched aquifers resulting from this system of fractured stratigraphy. According to Hobba (1987), the delineation of semi-perched from perched aquifer systems is governed by saturated thickness of the aquifer, with semi-perched representing the completely saturated condition. 


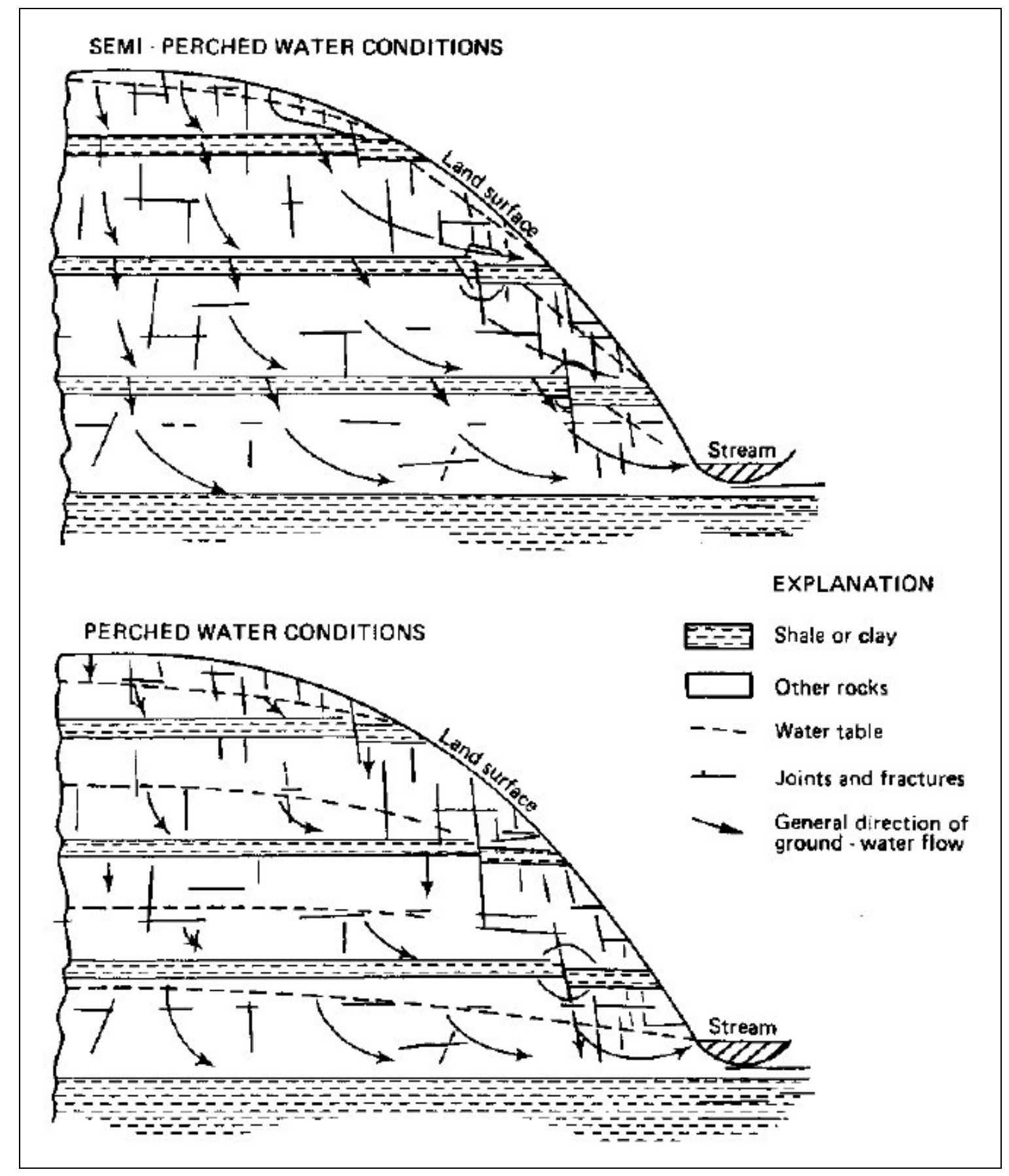

FIGURE 2 - Idealized Appalachian Groundwater Flow

(Ward and Wilmoth modified by Hobba, 1987, p. 157) 


\section{G. Historical Land Use}

From the dense network of streams and rivers to the mixed mesophytic forests and the underlying minerals, the Eastern Kentucky Coal Field hosts a bountiful supply of perhaps the most valued natural resources in North America. Human recognition of this natural wealth and the subsequent exploitation through practices such logging, farming, and mining have resulted in ecologic impacts of varying magnitude. Thus, the "premining" state of headwater streams and valleys is not necessarily their "natural" state. Implications of historical land use practices must be considered in the context of observed pre-mining geomorphic processes so as to avoid attributing undue responsibility for these implications to the coal mining and valley filling operations currently under study.

Early use of eastern Kentucky's natural resources by Native Americans was augmented as Euro-Americans began to infiltrate the region during the mid-eighteenth century through the Cumberland Gap and tributaries of the region's larger rivers (Raitz and Ulack, 1984). Rugged topography of the region led to sparse settlements occupying coves and hollows. Early land use consisted primarily of subsistence farming and involved the clearing of bottomland and hillside forests for pasture land and cultivation. Selective timber harvesting was undertaken to supplement the income of these family farms (Eller, 1995).

Industrialization of Appalachia began in the later years of the nineteenth century and brought with it increased exploitation of regional natural resources and, consequently, greater alteration of the land. Of significant initial impact was the transition of the mature forests of the mid-eighteenth century to the second- and third-growth stands 
of today. Acting as the springboard of this woodland alteration was the penetration of railroads into remote areas of the region circa 1890 . Selective harvesting of timber by denizens was overtaken by large-scale, ecologically unsustainable operations headed by outside interests. Logging economics fostered the swift conversion from towering oak, chestnut, maple, tulip poplar, or walnut to building lumber, cross-ties, firewood, and furniture. Business boomed most remarkably from 1890-1920 but still continues today (Eller, 1995). Early in the history of this plundering of the region's timber was a lack of conservational practices and regard for future vitality of the forest. However, recent legislation such as the Kentucky Agricultural Water Quality Plan of 1994 and the Kentucky Forest Conservation Act of 1998 (KYDF, 2006) have put significant emphasis on more ecologically benign techniques though the development of best management practices (BMPs).

Road building, often associated with logging, is another anthropogenic alteration to the land that may have significant consequences. The effects of cut-and-fill earthwork operations associated with road building are similar to logging and can lead to slope instability (Wohl, 2000). The construction of crossings or straightening of channels along roadsides can also alter stream morphology.

Depletion of timber reserves and an increased conservational awareness led to a shifting of economic gears toward the newly emerging coal industry early in the twentieth century. This industry has evolved throughout the region's history to that existing today. With evolved efficiency, current coal mining has allowed for the remining of former mine sites to extract coal reserves whose removal was formerly considered infeasible (USEPA, 2003). Often predating modern environmentally 
protective requirements such as the Surface Mining Reclamation and Control Act of 1977 (SMCRA), these old mines may have induced morphologic impacts of a different nature and magnitude that should be differentiated from those currently under consideration.

Despite recent measures to lessen ecologic impacts of anthropogenic land use, the scars of past agriculture, logging, mining, and road building may still persist along with present, yet perhaps lessened, impacts. As a practice common to these land uses, clearing a landscape of significant vegetal cover leaves soils exposed to erosion, increases runoff through the reduction of infiltration, interception, and evapotranspiration, and may increase the potential for landsliding (Wohl, 2000). Such processes largely alter the supplied sediment load and runoff to result in channel aggradation, bank erosion, loss of pool habitat and woody debris, and an increased potential for over-bank flow and increased channel evolution during flood events (Madsen, as cited in Wohl, 2000).

The delicate dependence of headwater stream morphology on sediment and water supply has been recognized by researchers such as Montgomery and Buffington (1997), with specific responses to alterations in headwater land use noted by researchers such as Price and Leigh (2006). Alterations due to mountaintop mining and hollow fill construction do not stand alone and should not be evaluated without regard for the possibility of alterations incurred through historical anthropogenic land uses such as agriculture, logging, road building, or even past mining.

\section{H. Headwater Streams and Their Morphology}

The streams disturbed in the construction of hollow fills constitute the uppermost extensions of the larger drainage network. For the purposes of this study, these streams may be referred to as headwater streams and represent the channel reaches for which 
direct post-mining restoration efforts would be of significant benefit to both local and downstream ecology, as well as hollow fill stability. Reaches of particular interest are those buried during construction of hollow fills. Consideration will also be given to stream reaches in the vicinity of sediment control ponds constructed downstream of hollow fills.

Despite being of relatively small size, headwater streams are numerous, comprising up to $80 \%$ of a drainage network's total stream length (Schumm, and Shreve, as cited in Benda et al., 2005). Due to the relative abundance and upstream-most position of headwater streams in the drainage network, these streams have a significant impact on various aspects of downstream ecology (Doppelt, as cited in USEPA, 2003). Major ecological functions performed by headwater streams include providing a unique interfacial environment between aquatic and terrestrial habitats; storing, processing and supplying nutrients and organic matter; and moderating stream flow, sediment load, and temperature. Headwater streams not only provide a unique habitat for indigenous and sometimes rare species, but they also influence water quality, sediment supply, and flow to downstream environments (Gomi et al., 2002). The importance of the ecologic functions of headwater streams underscores the need for restoration to reaches impacted by practices such as mountaintop mining and hollow fill construction. Consideration for channel morphology is key to the success of such efforts due to its influence on stream ecology (Wohl, 2000).

Channel morphology is largely a reflection of acting geomorphic processes. In low-gradient, alluvial rivers, morphology is relatively self-formed in the sense that the acting geomorphic processes are fluvial in nature. The development of headwater stream 
morphology, on the other hand, is subject to external controls such as spatially varying substrate, tectonic uplift, and bedrock interaction in addition to fluvial processes. These additional controls on channel morphology result in high spatial variability of headwater channel forms (Wohl, 2000).

\section{Pre-Mining Geomorphic Processes}

Pre-mining geomorphic processes vary from colluvial to fluvial in nature and collectively govern the transport of sediment through a down-gradient series of storage elements within the headwater system. As bedrock weathers on noses and side slopes, residual material is made available for movement. This residual material, either saprolite or soil, may be stored as a mantle layer directly over the parent bedrock. Accumulation of material in the mantle is balanced by the first geomorphic transport processes in the series that ultimately leads to deposition in higher-order streams. These hillslope processes remove sediment from mantle storage at the location of production and result in the down-gradient deposition of colluvium. Due to a lack of significant alluvial floodplain deposits in narrow headwater valleys, existent streams often lack a buffer zone from adjacent hillslopes. This lack of spatial isolation results in the deposition of colluvium directly within the hollow and channel way as well as along foot and side slopes (Hack and Goodlett, 1960).

The availability of direct sediment introduction in the form of colluvium signifies an intimate coupling of headwater streams and the adjacent hillslopes. In addition to providing sediment, hillslopes provide hydrologic control on streamflow through their response to precipitation. This stream flow, in turn, governs channel morphology. Slope stability is geometrically influenced by the base level imposed by this morphology. 
Changes in base level induced by evolving morphology physically alter slopes and the related response to precipitation, thus completing the cycle (Knighton, 1998). The interdependence of headwater streams and hillslopes is evident through recognition of this feedback loop.

In addition to minor transport by sheetwash (perhaps not minor in disturbed sites (Knighton, 1998)), geomorphic processes shaping hillslopes and introducing sediment to headwater streams predominately take the form of mass movement events. Mass movements of residuum and colluvium within headwater systems have, in a breadth of literature, been classified under various labels with varying definitions, including creep, landslides, debris flows and avalanches, slumps (Outerbridge, 1987), earthflows, debris slides, and soil creep (Dietrich et al., 1982). Driven by the force of gravity, the various forms of mass movement can be generally grouped on the basis of rate of movement. For the purposes of this study, events occurring rapidly on an episodic basis will be considered generally as landslides. The slow continuous movement of material will be considered creep.

In a discussion of zero-order basin topographic development, Tsukamoto and Minematsu (1987) point out the relation of these processes to their position along the hillslope profile. The convex uppermost section of the profile is dominated by in-place residuum. As the slope transitions from convex to planar to concave, creep gains in influence, evident in the general down-gradient thickening of a slowly moving mass of material. As creep and weathering continue, the depth of this mass increases to a critical point of instability for a given slope gradient, thus inducing sudden and episodic land sliding. If these landslides occur along the convex or planar portions of the hillslope 
profile, they contribute to the downhill storage of colluvium along the concave portion. Further landsliding may be induced within this concave section of the profile as colluvial storage increases and creep contribution from uphill sources continues. Additionally, the occurrence of landsliding may be exacerbated on convergent slopes which concentrate saturated interflow and groundwater flow (Tsukamoto and Minematsu, 1987).

In a physiographic study of the Appalachian Plateau, Outerbridge (1987) points out the dominant role of both episodic and continuous mass movement events in the introduction of sediment to streams. Convergent slopes of the region store the majority of slope debris and serve as initiation sites for episodic debris avalanches. As described by Outerbridge, the debris avalanches within the region are linear features up to $10 \mathrm{~m}$ (32.8 ft) wide and about $1 \mathrm{~km}(0.62$ miles) long. Direct deposition of sediment into channelways by this form of mass movement is accompanied by slumps in the toes of avalanche deposits. Outerbridge also notes the role of creep in sediment introduction to streams of the Appalachian Plateau.

Considering the convergent slopes (e.g., Hack and Goodlett's hollows and Tsukamoto and Minematsu's zero-order basins) from which channels originate, the down-gradient series of sediment transport and storage processes begins to demonstrate fluvial influence at the channel head. Dietrich and Dunne (1993) define the channel head to be "the upstream boundary of concentrated water flow and sediment transport between definable banks" (p. 178). At this point, the down-gradient trend of increasing runoff erosion potential relative to sediment supply reaches a critical point manifested by the transition from unchannelized stored colluvium to a morphologically identifiable channel. While also influenced by climate and land use, the position of the channel head may 
fluctuate in response to sudden changes in the volume of colluvium stored at the upper extent of a headwater stream. Such episodic changes may be brought on by landsliding as described above. The introduction of landslide debris may bury the upper extent of a stream, effectively moving the channel head downstream. Subsequent headward advancement of the channel head may occur through the action of various fluvial processes that evacuate stored colluvium and deliver pulses of sediment to downstream reaches (Dietrich and Dunne, 1993).

Fluvial processes entraining, transporting, and depositing sediment are governed by channel slope, hydrology, and substrate. Characteristic of headwater streams are steep gradients, shallow flow, and the presence of large sediment clasts (Montgomery and Buffington, 1997) that affect fluvial sediment transport due to their influence on stream hydraulics. Large particles and shallow flow result in an increased relative roughness. As roughness elements increase in size relative to flow depth, the shape, spacing, and location of individual clasts may begin to affect stream hydraulics and sediment transport in complex ways and cause a deviation from uniform flow. For example, local supercritical flow or hydraulic jumps may occur in the vicinity of large particles on steep slopes (Lisle, 1987). Locations of supercritical flow may result in focused areas of erosion, while hydraulic jumps may decrease flow energy (Chow, 1959).

Despite localized supercritical flow and steep channel gradients, the backwater effects induced by large clasts of colluvium and shallow flow generally limit bedload entrainment and transport capacity in headwater streams. As discussed by Montgomery and Buffington (1997), chronic efficacy may be limited to the extent that bedforms no longer demonstrate fluvial organization in headwater reaches. Only rare storm events 
may be capable of producing runoff with depths sufficient for fluvial sediment transport of these large roughness elements.

In addition to limiting fluvial organization of bed material, low sediment transport competence may lead to a net increase in material storage within the hollow of the headwater system (Hack and Goodlett, 1960). Instability may result at some critical depth and result in a sudden debris flow as described by Benda and Dunne (1987). The large amount of material transported during debris flows has led several researchers (i.e., Benda and Dunne, 1987; Gomi et al. 2002), to suggest their domination of fluvial sediment transport processes within headwater channels. It is important to note, however, that these researchers focused primarily on regions of high relief. The comparatively subdued topography of the Appalachian Plateau may limit the frequency of debris flows and favor sediment transport by fluvial processes.

Whether through fluvial bedload transport or episodic debris flows, sediment is eventually removed from storage within the hollow, channel way, or foot slopes of the headwater system and deposited as yet another form of storage. This downstream form may be considered alluvial and consists of elements including bedform, floodplain, terrace, or debris fan deposits. In these lower reaches and the remaining downstream extension of the drainage network, the introduction of sediment and organization of stream morphology becomes dominated by fluvial rather than colluvial processes (Gomi et al., 2002). While limited and sporadic, alluvial storage exists within the lower reaches of the headwater streams considered in this study.

Through erosion, transportation, and deposition, the array of colluvial and fluvial geomorphic processes of headwater streams plays a major role in sculpting the landscape. 
As a physical product of these processes, the longitudinal profile of a river may give insight to their nature. Of particular relevance is the role of the profile in setting a boundary condition for hillslope processes (Knighton, 1998). This is of significant importance in headwater reaches where hillslopes and streams are intimately related.

As presented by Knighton, the longitudinal profile of a river may be described by the relationship of channel elevation to distance downstream. This relationship is often modeled as exponential, logarithmic, or power forms (Snow and Slingerland, as cited in Knighton, 1998), all three of which share the commonality of a smooth concave upward shape. In the profile of a natural river, the smoothness modeled by these relations is often obscured by small-scale convexities caused by the outcropping of resistant bedrock strata, introduction of a coarser sediment load, tectonic activity, or effects of historical changes in base level (Knighton, 1998). If the smooth, concave shape of a river profile is considered to be an indication of quasi-equilibrium as described by Sinha and Parker (1998), deviations such as convexities may represent locations of active geomorphic activity.

\section{J. Mountaintop Coal Mining}

The coal of the Appalachian Plateau has been mined by various techniques dating back to pick-and-shovel methods of the early eighteenth century (USEPA, 2003). Currently, the coal mining industry is trending away from underground methods and toward surface methods that involve the removal of large quantities of overburden (rock overlying coal deposits) to access coal reserves. Technological advancement in mining equipment has spurred this trend and made surface mining techniques more economically feasible (USEPA, 2003). Of particular interest in this study are the surface mining techniques resulting in the necessity for hollow fills as overburden disposal sites. Such 
techniques may be grouped under the term "mountaintop mining." Specific methods encompassed by this term include contour mining, area mining, and mountaintop removal mining. These three methods are described in the USEPA's Draft Programmatic Environmental Impact Statement (2003) and are briefly summarized below.

Of the three methods, contour mining has the least impact on the landscape. Overburden removal is limited to hillsides and involves the excavation of coal along an outcropping. Excavation proceeds inward toward the center of the mountain as coal is removed from the seam at the base of a highwall cut. The highwall follows the contour of the coal seam (Figure 3) and may extend laterally around the hillside.

Alteration of the landscape is significantly greater with the method of area mining (Figure 4), which cuts a straight highwall perpendicular to the direction of advancement.

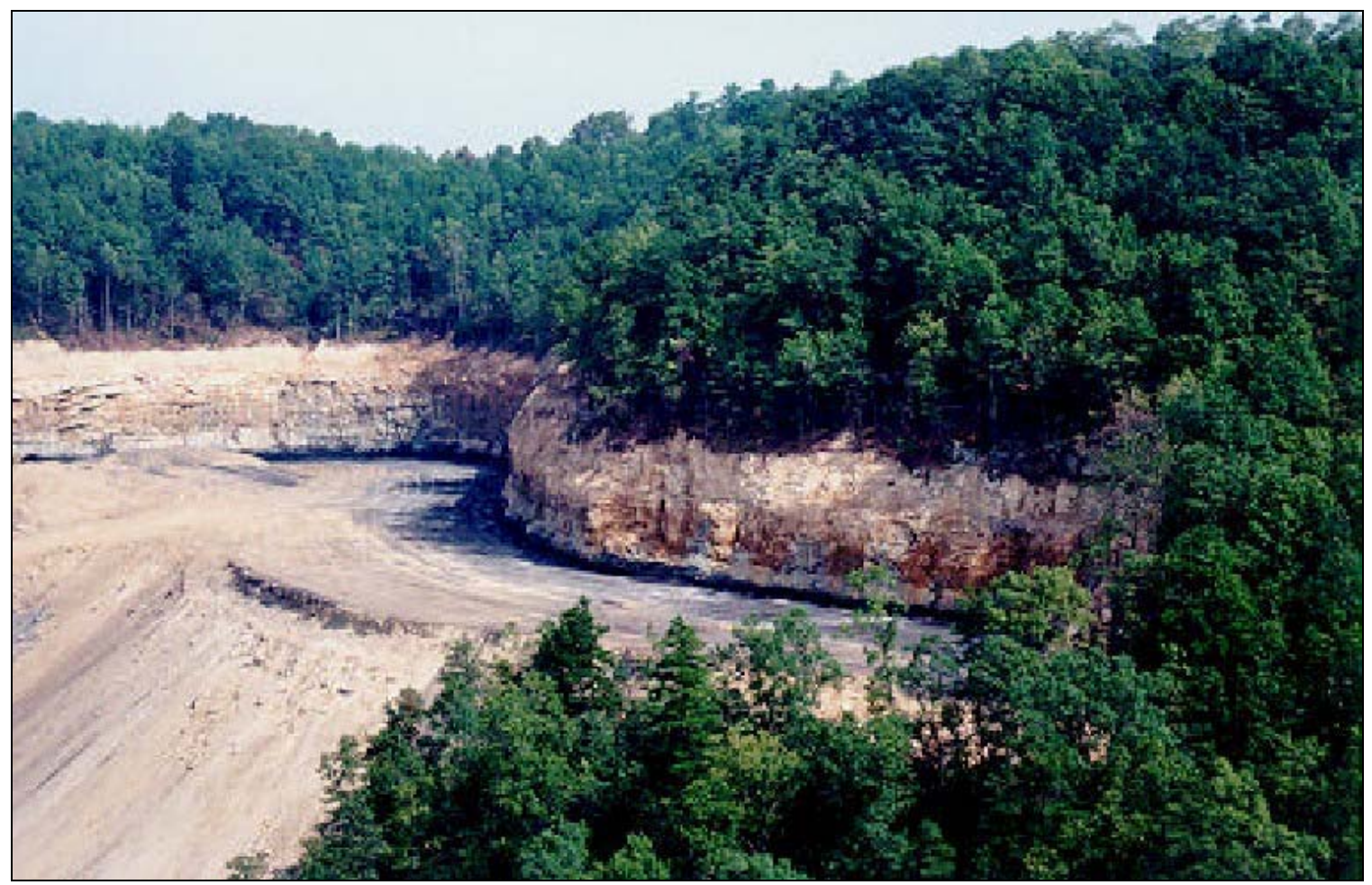

FIGURE 3 - Typical Sinuous Highwall Cut of Contour Mining Operation (Carr, 1999, as displayed in USEPA, 2003) 


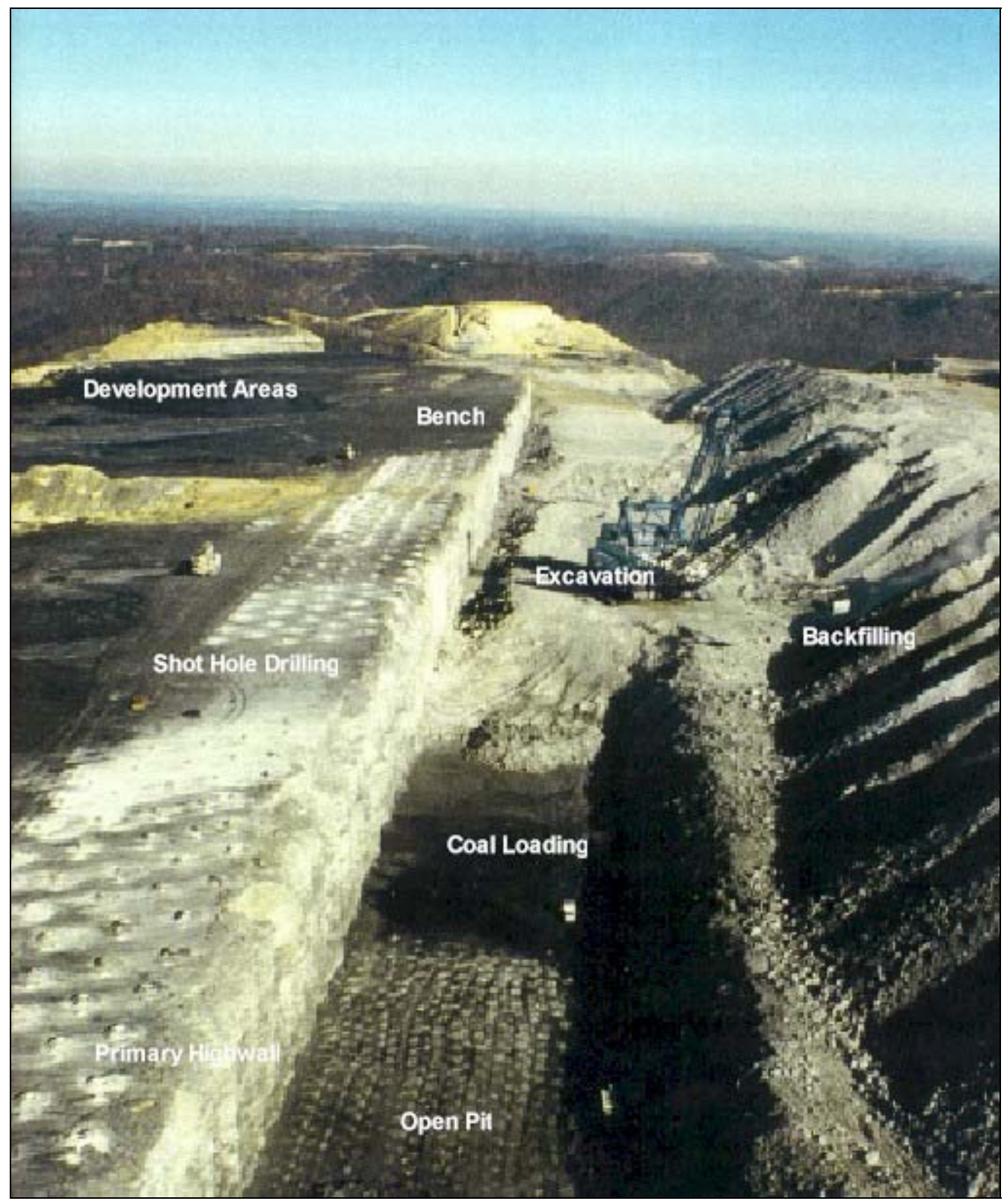

FIGURE 4 - Typical Area Mining Operation

(Arch Coal, Inc., 1999, modified and displayed by USEPA, 2003, p. III.I-19)

The highwall spans the entire width of the hill and progresses across it, leaving a level plateau in its wake and large volumes of overburden to dispose of as hollow fill or as backfill onto the leveled ground. Highwall progression is economically limited by the ratio of overburden removed to coal recovered. When mining economics allow for the excavation to progress across the entire mountain, ultimately removing all of the coal 
reserves as well as the mountaintop itself, area mining may be specifically referred to as mountaintop removal mining. In practice, "mountaintop removal" often takes on a broader meaning to encompass other methods characterized by the removal of significant amounts of overburden.

Characteristic of all mountaintop mining methods is the removal of overburden to access coal reserves. Once removed through blasting and excavation (often with dragline excavators in area or mountaintop removal operations), the formerly consolidated rock that existed as overburden is referred to as unconsolidated spoil. Under the Surface Mining Control and Reclamation Act of 1977 (SMCRA), which applies to all of the fills in this study, this spoil is to be returned to the benches and plateaus created during mining so as to return the landscape to its approximate original contour (AOC) as defined by the law (405 KAR 1:010):

"Approximate original contour" means that surface configuration achieved by backfilling and grading of the mined area so that the reclaimed area, including any terracing or access roads, (when not necessary to support its approved post-mining use) closely resembles the general surface configuration of the land prior to mining and blends into and complements the drainage pattern of the surrounding terrain, with all highwalls and spoil piles eliminated; water impoundments may be permitted where the cabinet determines that they are in compliance with 405 KAR 1:220.

Variance from the AOC requirement may be legally approved only in circumstances in which a post-mining land use for the flattened land has been proposed and meets the requirements of 405 KAR 1:240.

The spoil disposed of in achieving AOC is referred to as backfill. Despite backfilling, excess spoil may exist due to increased volume by bulking of the once consolidated bedrock and limits on stable backfilled gradients. Spoil not used in backfilling operations is often deposited in adjacent valleys as hollow fills. As previously 
mentioned, this form of spoil disposal directly impacts headwater reaches and is the subject of focus for this study. Although generally referred to here as hollow fill, the spoil occupying headwater systems is commonly described using other terms as well, especially "head-of-hollow fill," "hollow fill," "valley fill," or "durable rock fill." Depending on the source, these terms may represent different forms of excess spoil disposal structures. The U.S. Office of Surface Mining (OSM) regulations outlined in Kentucky Administrative Regulations (i.e., 405 KAR 1:141) defines "head-of-hollow fill" as

a fill structure consisting of any material, other than coal processing waste and organic material, placed in the uppermost reaches of a hollow where side slopes of the existing hollow measured at the steepest point are greater than twenty (20) degrees or the average slope of the profile of the hollow from the toe of the fill to the top of the fill is greater than ten (10) degrees.

"Valley fill" is defined as

a fill structure consisting of any material other than coal processing waste and organic material that is placed in a valley where side slopes of the existing valley measured at the steepest point are greater than twenty (20) degrees or the average slope of the profile of the valley from the toe of the fill to the top of the fill is greater than ten (10) degrees.

Durable rock fill structures are an alternative to head-of-hollow fills or valley fills and are not strictly defined in 405 KAR 1:141. While resembling the previously defined structures, these fills are often constructed in a different fashion. A common method of construction involves the end-dumping of spoil to form a single lift (Figures 5 and 6) as opposed to the multiple, thinner horizontal lifts used in head-of-hollow or valley fill construction. Once all excess spoil has been end-dumped into a valley, the final configuration (Figure 7) is achieved through grading by bulldozers. 


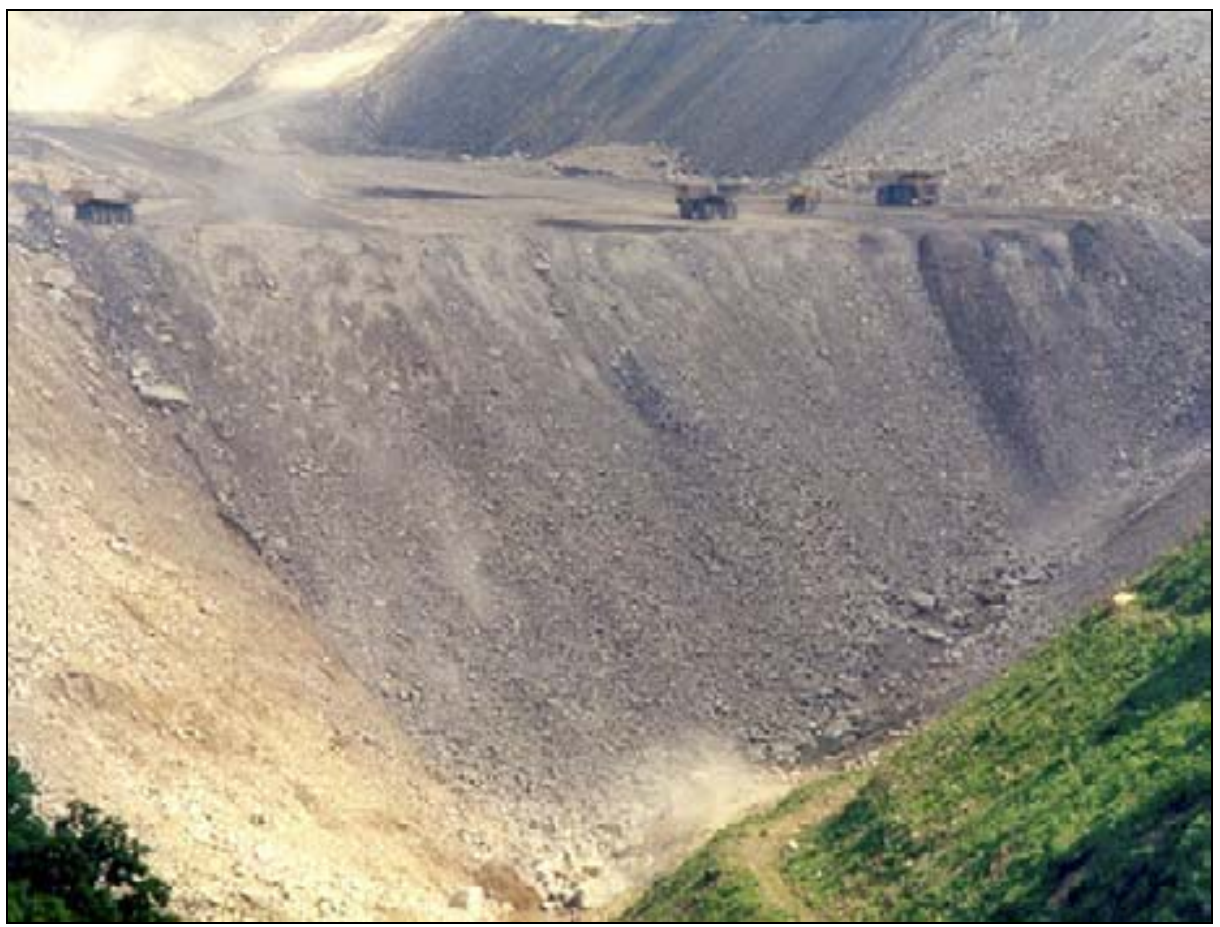

FIGURE 5 - End-dumping During Construction of a Durable Rock Fill (Arch Coal, Inc., 1999, as displayed in USEPA, 2003, p. III.K-7)

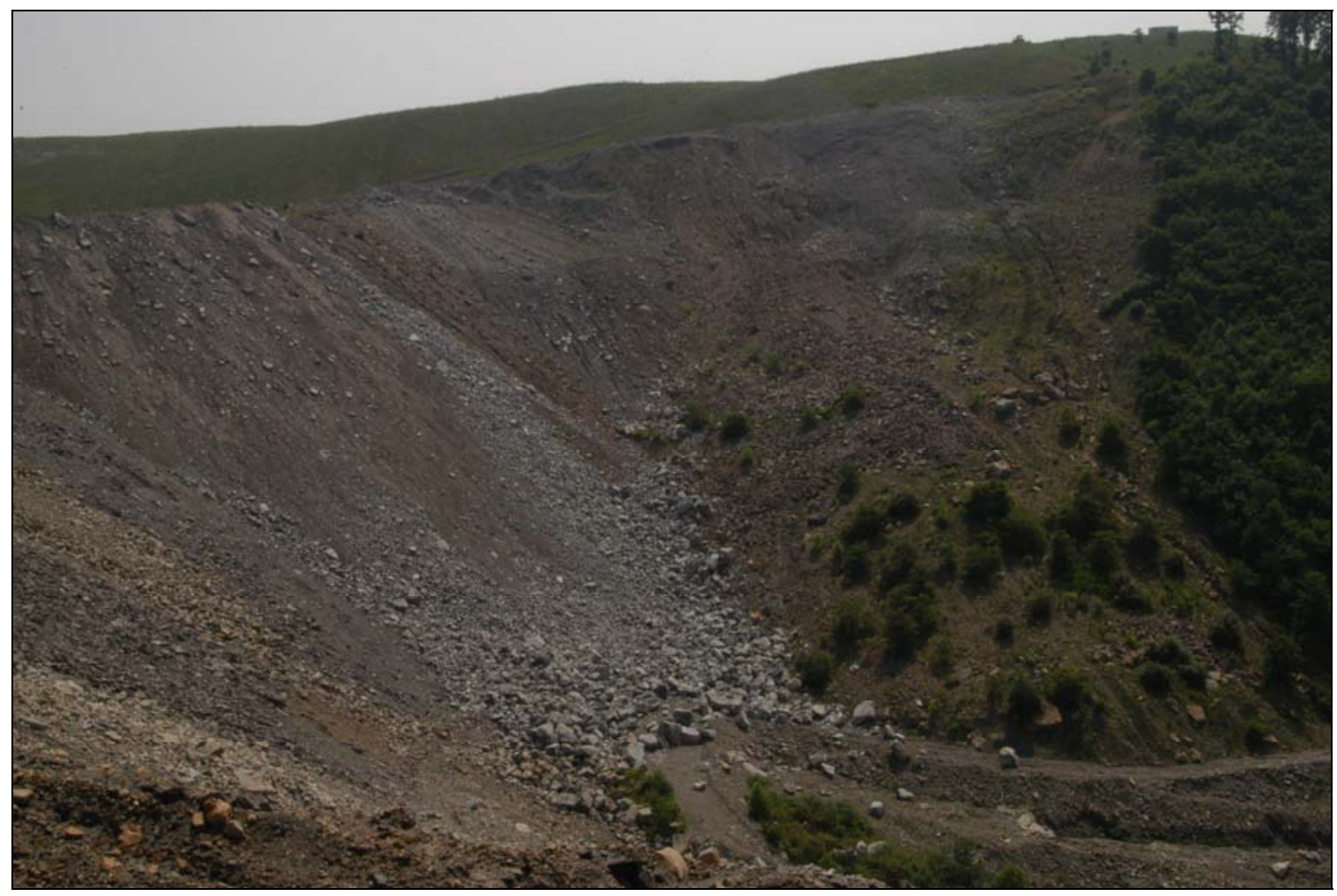

FIGURE 6 - Observed Durable Rock Fill in Construction near Study Sites 


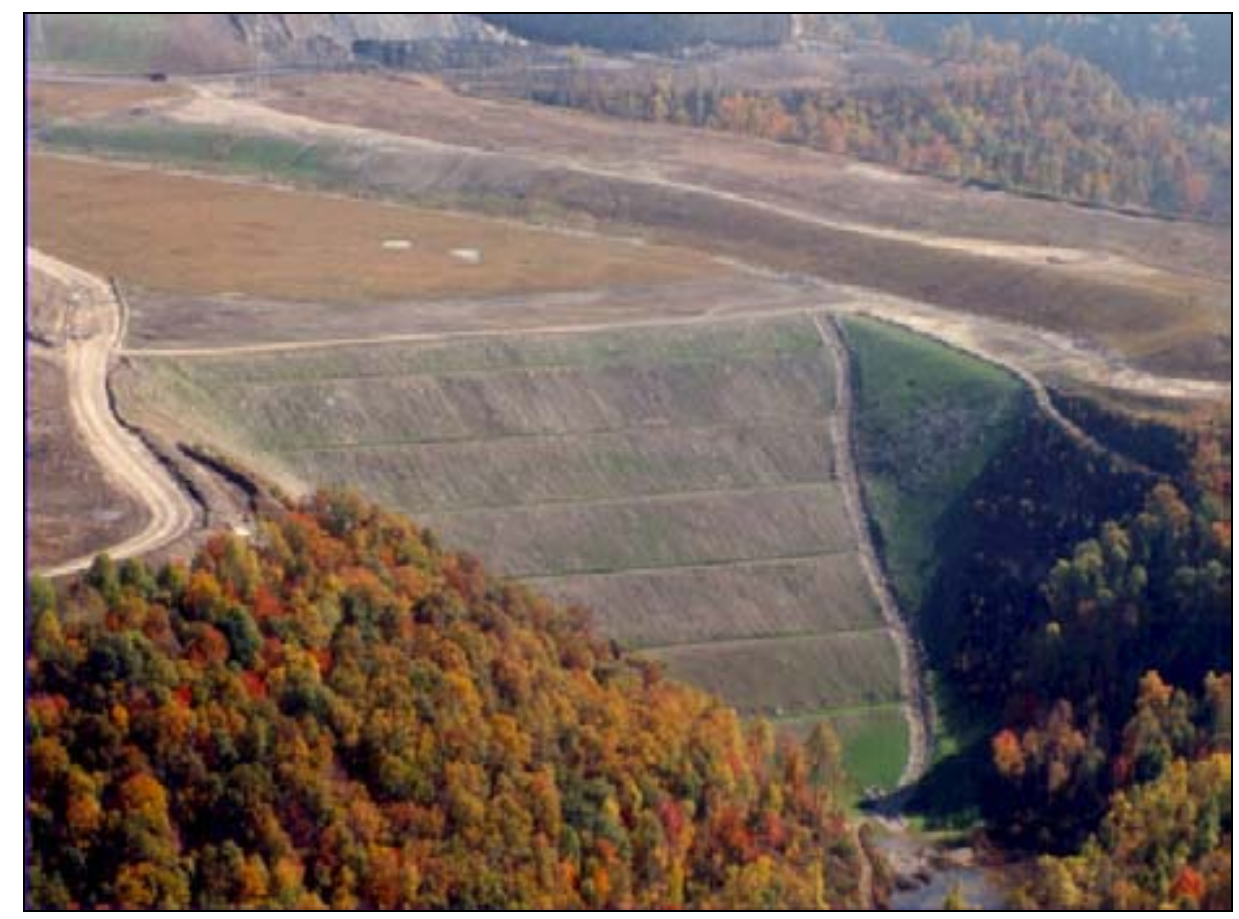

FIGURE 7 - Durable Rock Fill after Completion of Construction (Arch Coal, Inc., 1999, as displayed in USEPA, 2003, p. III.K-7)

Due to the relative frequency and presence of durable rock fills (generally referred to as hollow fills) within the analyzed headwater systems of this study, the typical physical attributes and construction procedures of this form of fill will be discussed. As the name implies, the material composing durable rock fills is required by law to be predominately resistant rock, such as hard sandstone, as determined by the slake index and durability tests. Nondurable rock such as shale is limited to no more than twenty (20) percent of the total fill volume (405 KAR 1:141). The common configuration of a durable rock fill and typical dimensions as described by 405 KAR 1:141 are shown in plan, profile, and cross-sectional-views of Figures 8, 9, and 10, taken from permitted design plans submitted by Summitt Engineering, Inc., for Holston Mining, Inc.

Fills are configured to prevent excess erosion, infiltration of surface water, and accumulation of subsurface water. Erosion is limited by a terraced face (shown in 


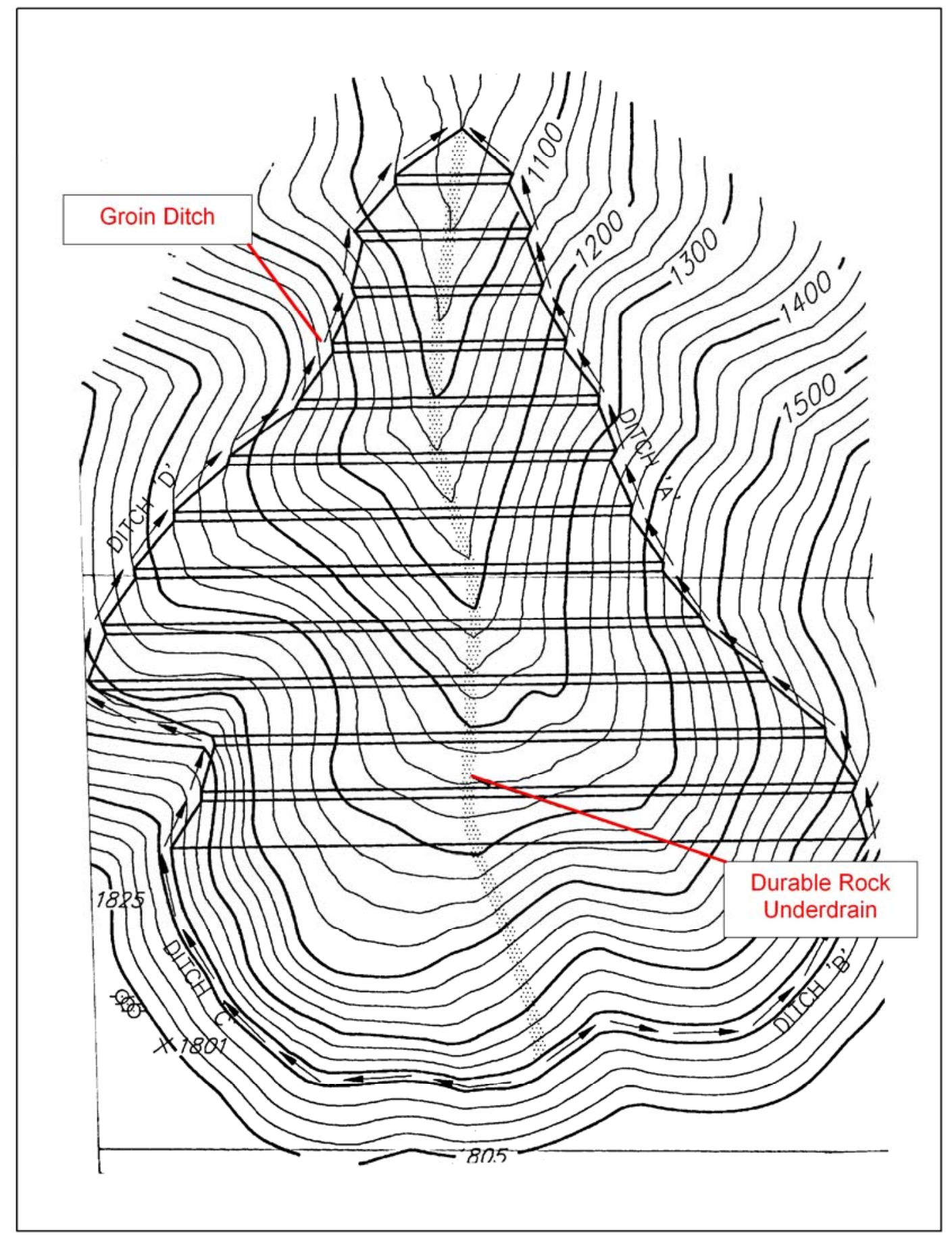

FIGURE 8 - Permitted Design Plans of HF 11 from Permit No. 898-0349 Displaying Typical Durable Rock Fill Configuration and Surface (Groin Ditches) and Subsurface (Underdrain) Drainage 


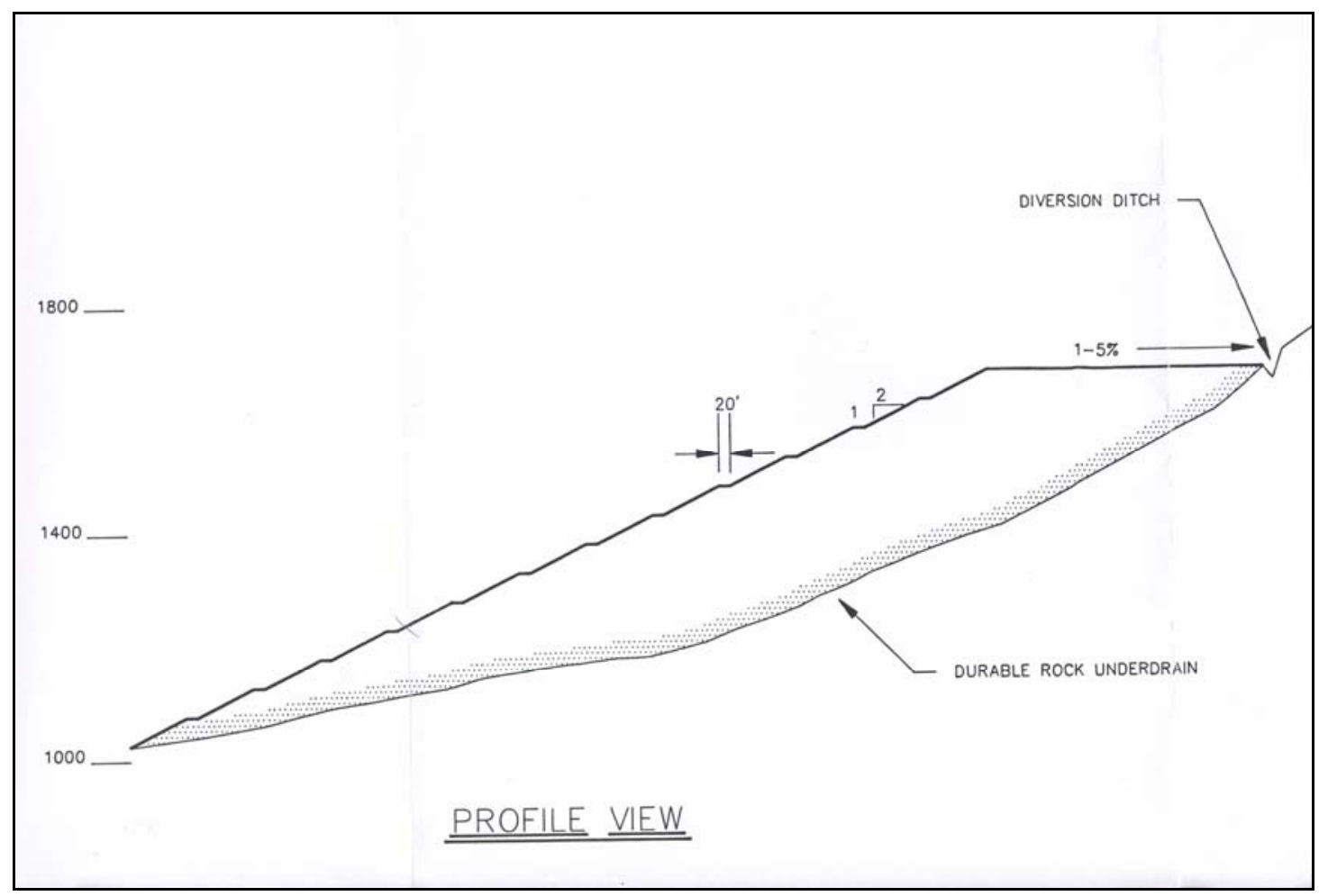

FIGURE 9 - Permitted Profile View of HF 11 from Permit No. 898-0349

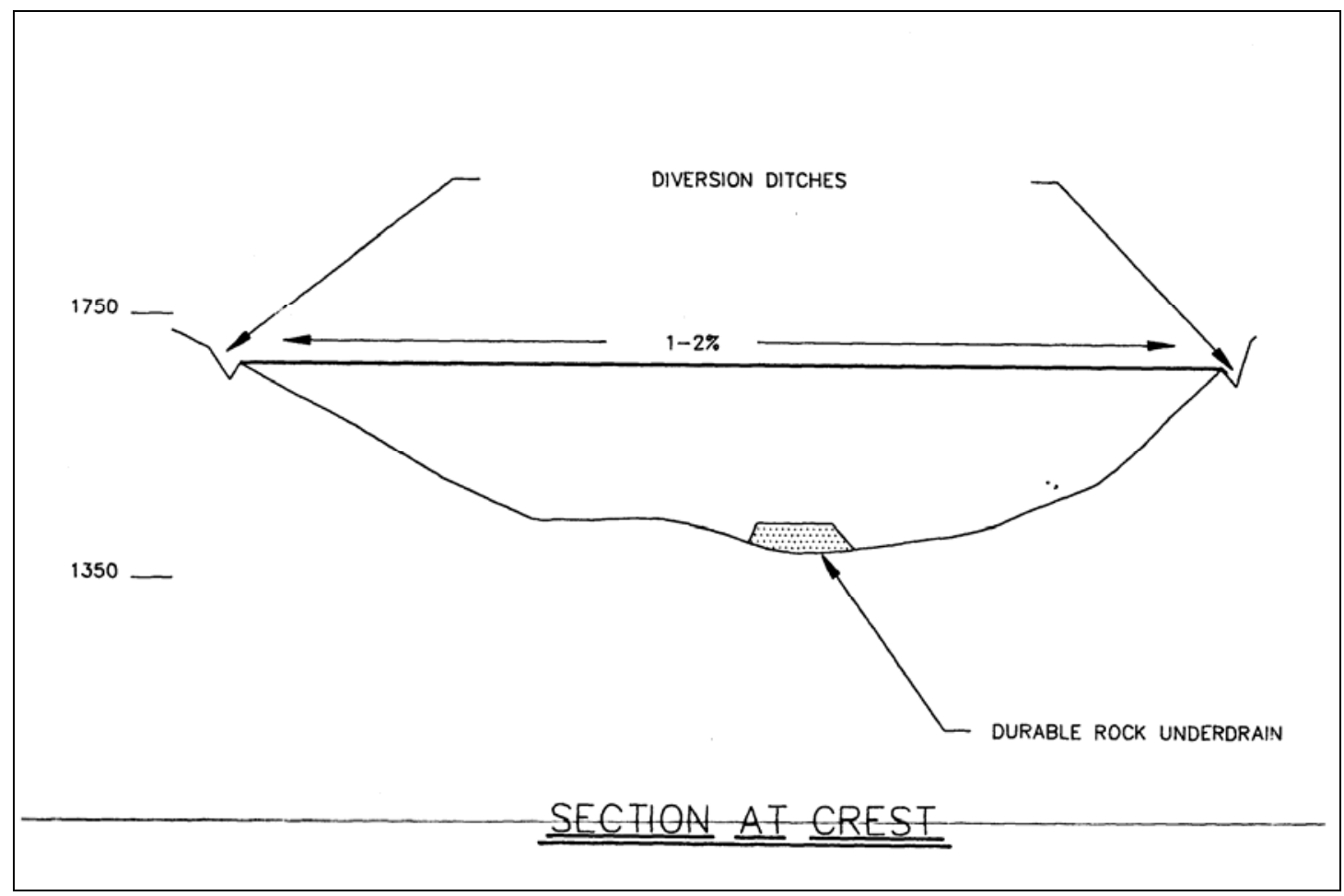

FIGURE 10 - Permitted Cross Section at Crest of HF 11 from Permit No. 898-0349 
Figures 9 and 11) that intercepts overland flow in down-slope increments before erosive potential is realized. Overland flow accumulating on back-sloping benches (detailed in Figure 11) is conveyed off the face of the fill by the lateral slopes shown in the cross section of Figure 10. The slopes of terrace faces and benches prevent ponding of surface water, thus limiting infiltration into fill material.

Runoff from the fill face is channelized in boulder-lined drains, known as groin ditches, which border the fill. Groin ditches are constructed along the intersection of the fill and the natural hillslope (Figure 12) and collect and convey the surface water shed from both. As required by 405 KAR 1:141, these permanent diversion channels are to be constructed off the fill and to dimensions capable of conveying runoff from the 100-year 24-hour precipitation event. Designing for this rare hydrologic event decreases the

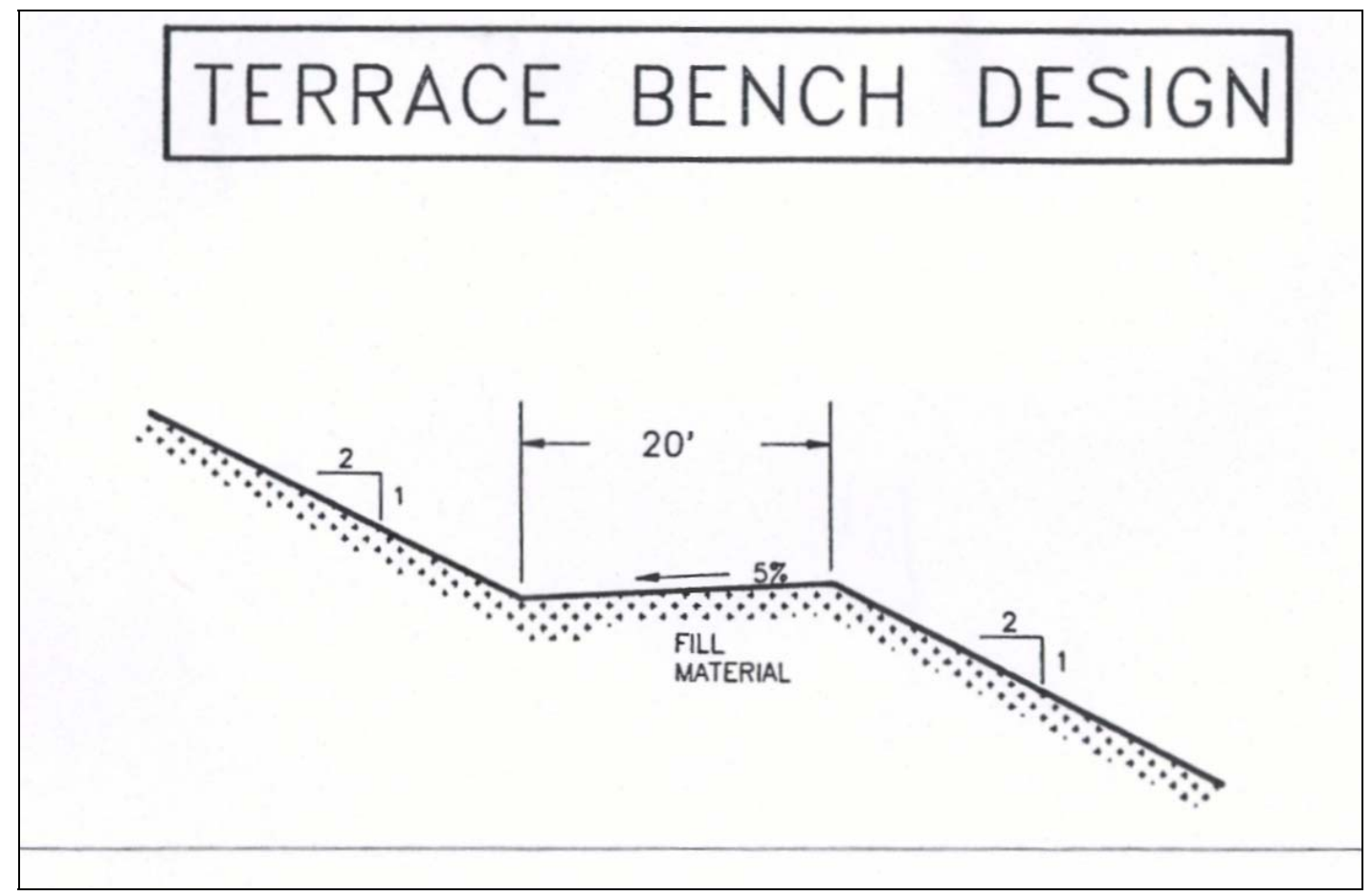

FIGURE 11 - Detail of Typical Durable Rock Fill Terrace Bench from Permit No. 898-0349 


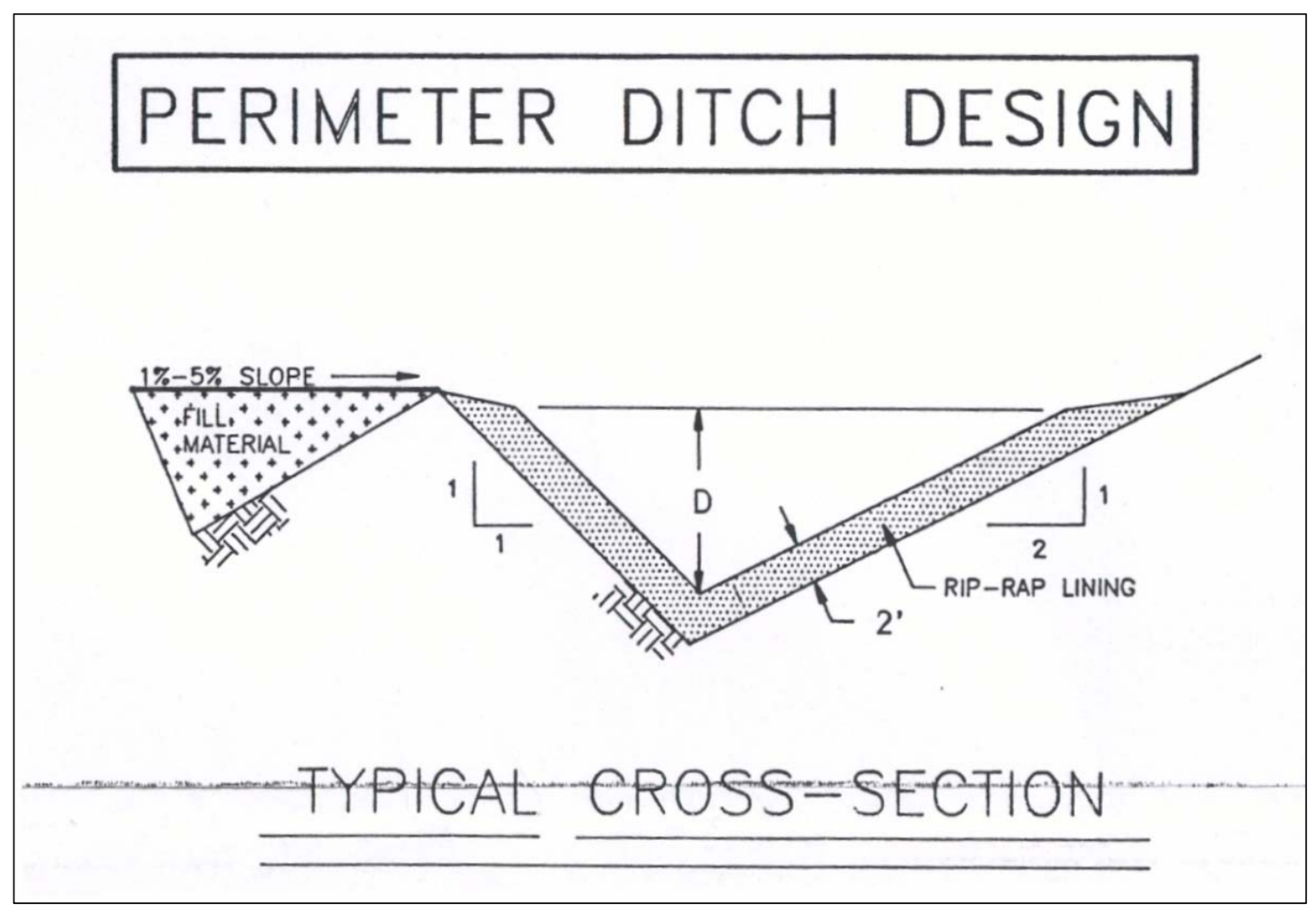

FIGURE 12 - Detail of Typical Groin Ditch Cross Section from Permit No. 898-0349

possibility of erosive surface flow overtopping groin ditch banks and flowing down the face of the fill. In examined permit applications, design flow rates were calculated using the rational method (Figure 13a). Manning's formula, which assumes uniform flow, was then used with proposed channel gradients and cross-sectional geometry to calculate the required depths (Figure 13b).

The accumulation of subsurface water within the fill is limited by subsurface drains known as underdrains or French drains (Figure 14). Underdrains extend from the toe of the fill upstream along natural or man-made watercourses in the foundation material to the fill crest. Drains are to be constructed of durable rock protected from clogging through gradation of the rock, filter material, and the exclusion of non-durable 
(a)

ATTACHMENT 32.2. B

DIVERSION DITCH DESIGN METHODOLOGY

The diversion ditches for Hollow Fill NO. IV were designed using the Rational Method $Q=C I A$.

$\mathrm{C}=$ see attached page .

$\mathrm{I}=$ Intensity $-8.08 \mathrm{in} / \mathrm{hr}-$ for $100 \mathrm{yr} / 24 \mathrm{hr}$ precipitation event.

$A=$ Area in acres.

DITCH DESIGN CALCULATIONS

Ditch Number

A

B

C

D

(b)

)

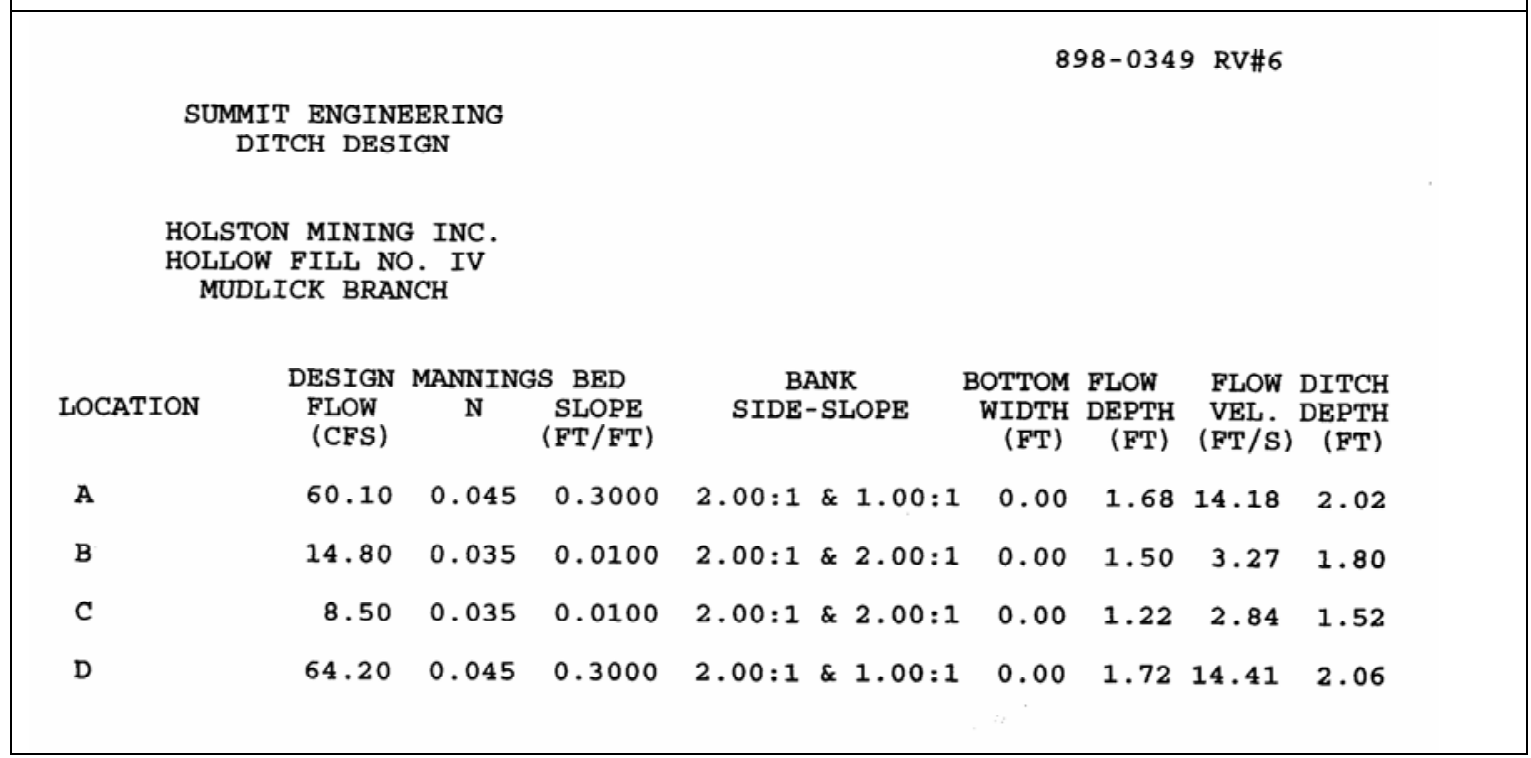

FIGURE 13 - Design Calculations for Sizing a Groin Ditch of HF 4 from Permit No. 898-0349
A Q (cfs)

$24.79 \quad 60.1$

$3.50 \quad 8.5$

$\begin{array}{lllll}0.30 & 8.08 & 6.10 & 14.8\end{array}$

$\begin{array}{llll}0.30 & 8.08 & 26.48 & 64.2\end{array}$ 


\section{FRENCH DRAIN DESIGN}

FRENCH DRAINS MUST BE A MINIMUM OF 8' HIGH $\times 16$ ' WIDE, $10 \%$ ROCK LESS THAN 12" AND NO SINGLE ROCK LARGER THAN $25 \%$ OF THE WIDTH OF THE DRAIN.

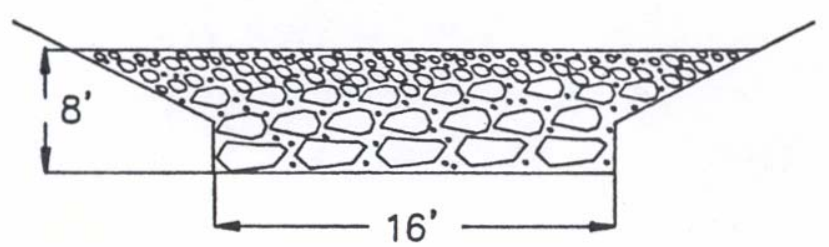

FIGURE 14 - Detail Underdrain Cross Section from Permit No. 898-0349

rock. Commonly, a single drain is constructed along the longitudinal axis of the fill with lateral tributary drains extending to any potential natural seeps or springs as necessary. Without underdrains, subsurface water may accumulate within the fill material and reduce the shear strength of fill material. Loss of material shear strength would increase the potential for structural failure of the fill. The prevention of subsurface water accumulation by underdrains is augmented by the minimization of infiltration provided by grading of the fill face and the presence of groin ditches.

In addition to the hollow fill itself, sediment control structures are erected within the headwater system. During construction of the fill, non-vegetated earth is exposed to weathering elements and prone to subsequent erosion. In an effort to minimize the introduction of excess sediment to downstream waterways, rock check dams and sediment ponds are installed.

The surface drains of a fill terminate at a confluence with each other and the natural stream channel at the fill's toe. At this point a rock check dam is often constructed 
as a preliminary measure for sediment retention (405 KAR 16:070 §1(2)). Check dams are typically constructed of large boulders of blasted material, as can be seen in Figures 15 and 16. The increased area of disturbance of larger fills may lead to the necessity of multiple such structures in series (Reclamation Advisory Memorandum (RAM) \#135).

The primary site of sediment detention is a sediment pond located downstream of a fill or multiple fills (Figures 17 and 18). As is the case with the fills of this study, such basins may be created by constructing an embankment across the natural drainage way. Throughout the course of mining and fill construction, the disturbed area contributes sediment that fills the pond. Ponds are to be maintained throughout this period of time and are to be removed along with the impounded sediment only after all backfilling, grading, and re-vegetation have been completed within the disturbed area upstream (405 KAR 16:070).

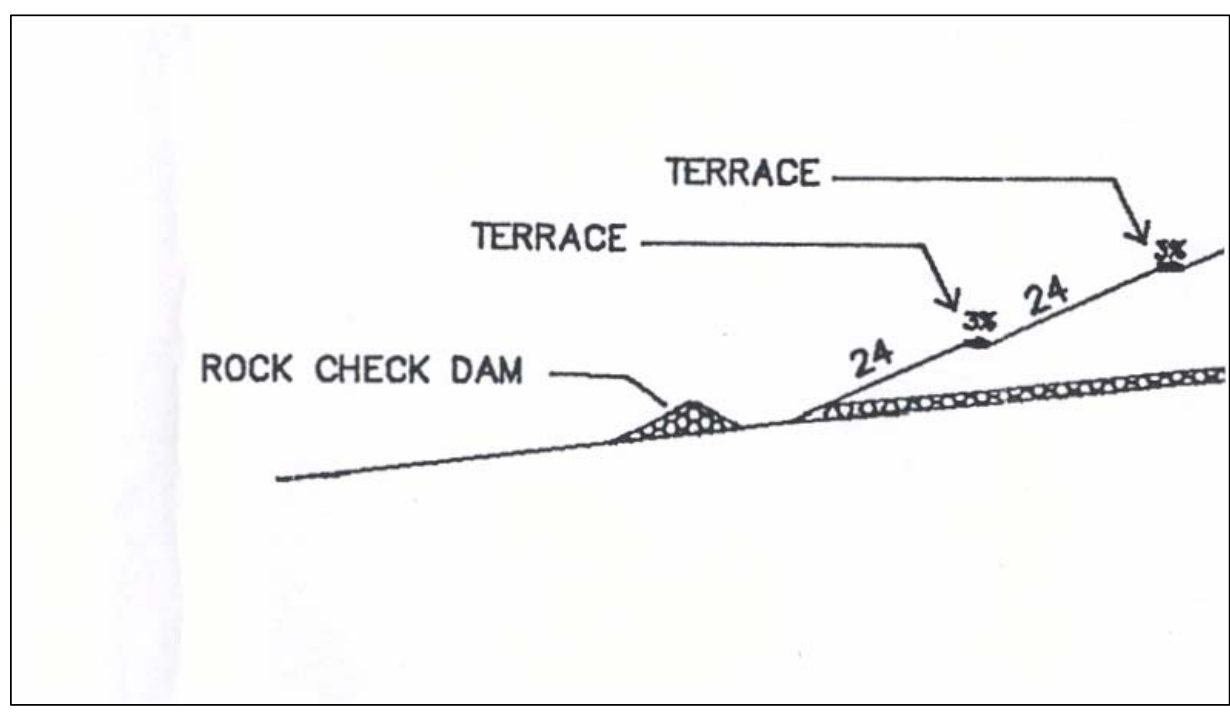

FIGURE 15 - Design Drawing of Rock Check Dam at Toe of a Hollow Fill from Permit No. 897-0367 


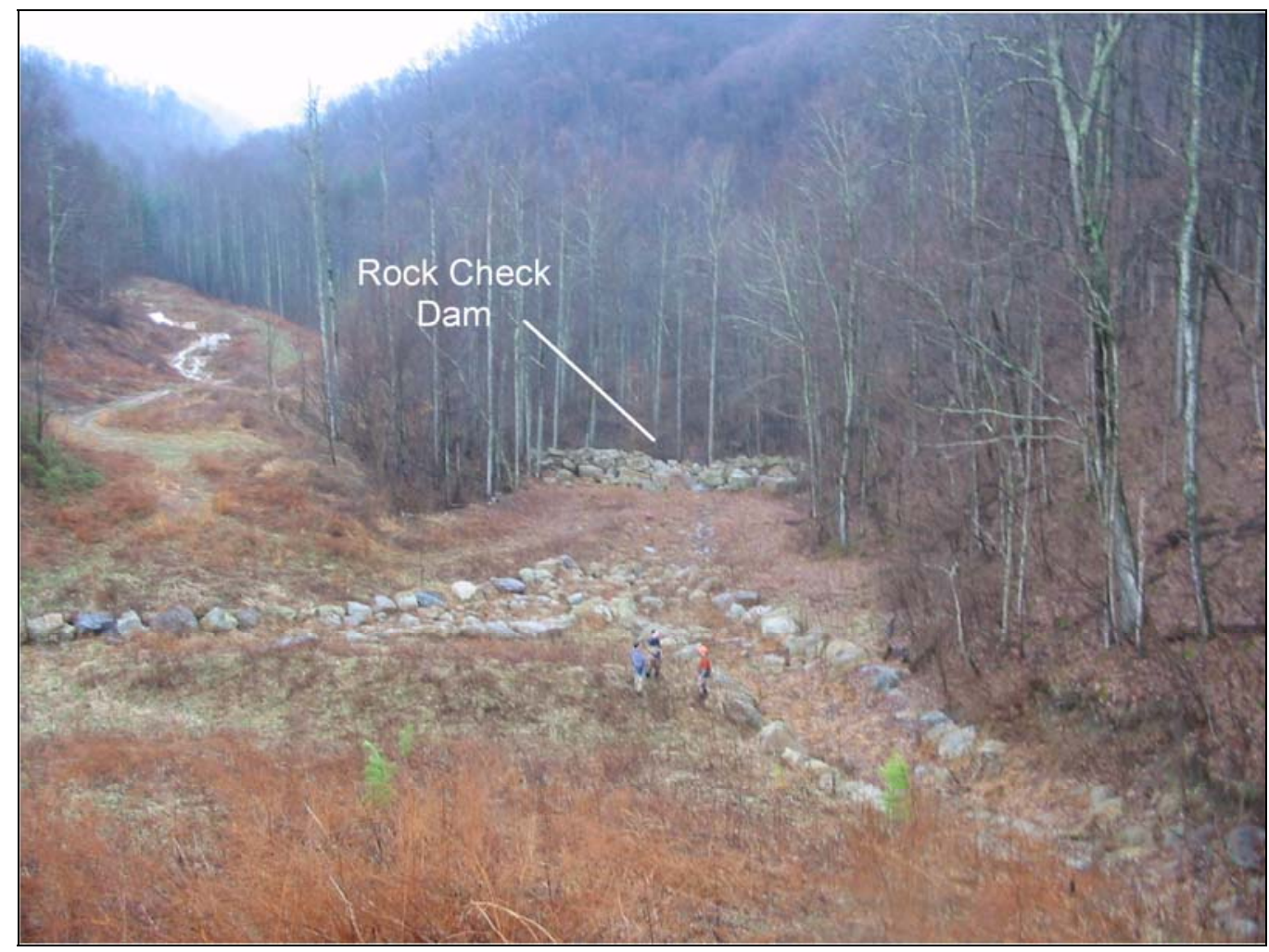

FIGURE 16 - Rock Check Dam at HF 1 from Permit No. 898-0349

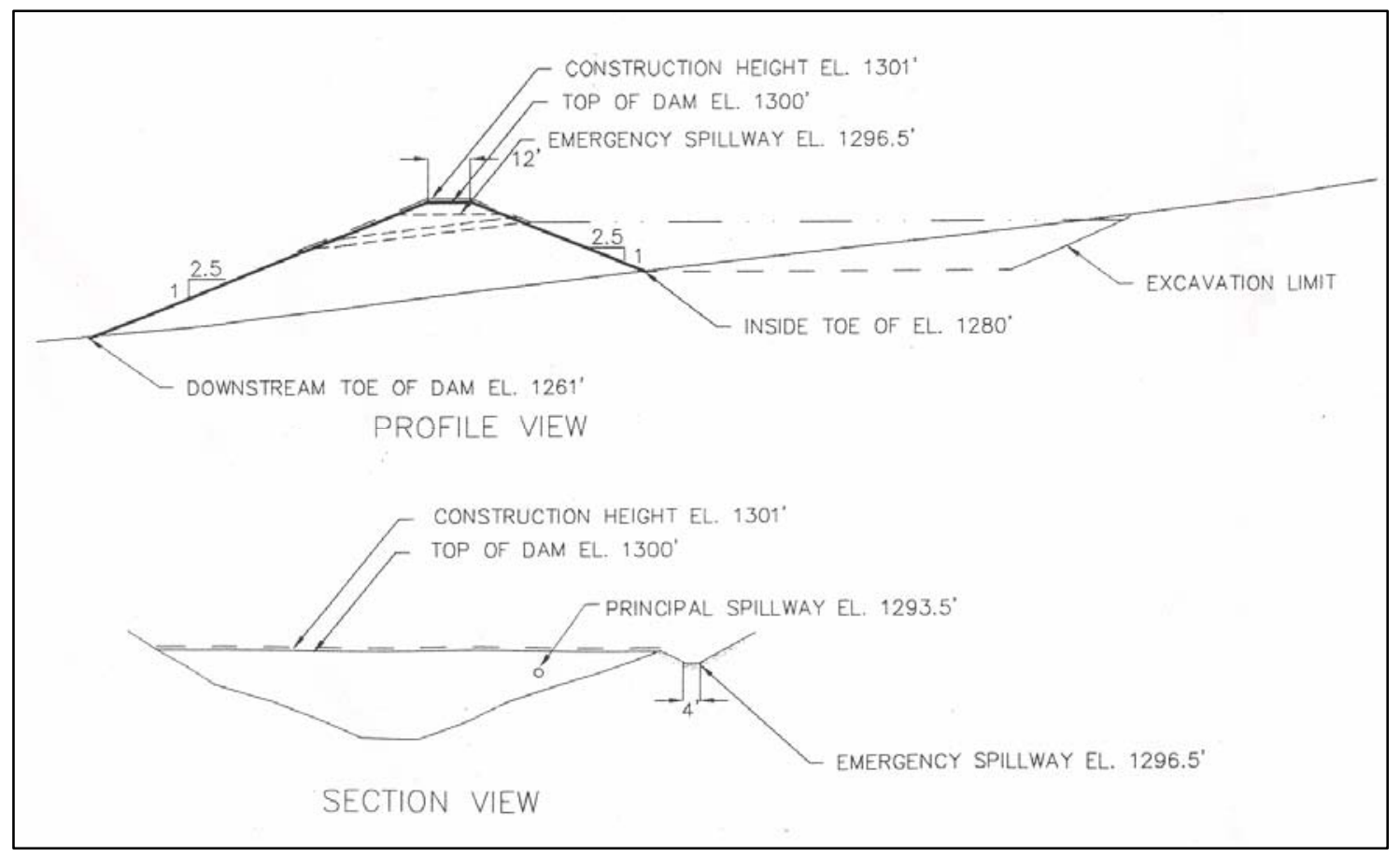

FIGURE 17 - Design Drawing of a Sediment Pond and Embankment Downstream of HF 11 on Permit No. 898-0349 


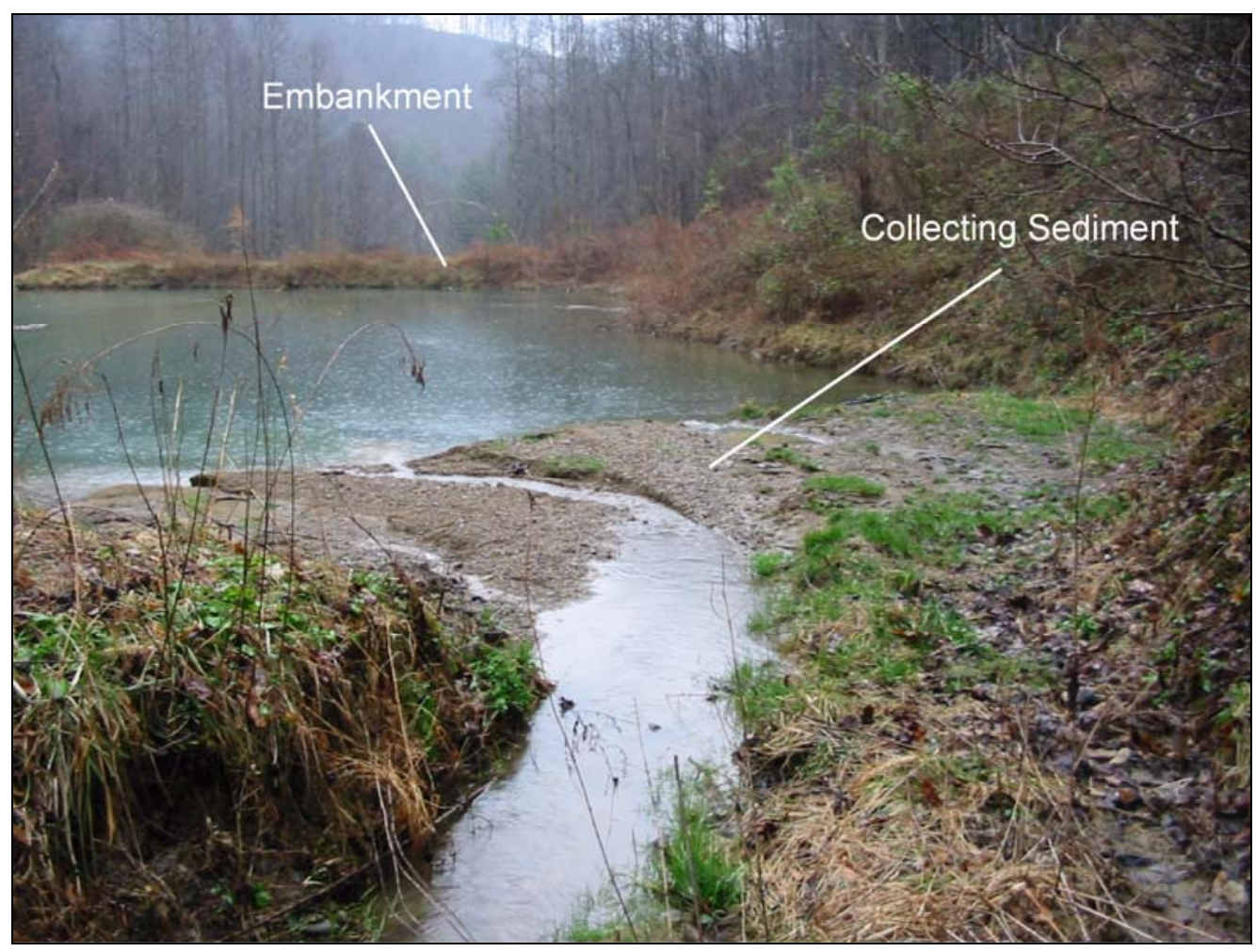

FIGURE 18 - Sediment Pond Below HF 1 and HF 2 During Time of Use (Prior to Field Visit) 


\section{PROCEDURES}

Geomorphic conditions and processes existing within the headwater environments impacted by mountaintop mining and hollow fill construction were evaluated based on a selection of filled valleys in the Eastern Kentucky Coal Field. Data relevant to the development of stream restoration considerations were collected both remotely via mining permit files and aerial photography and directly via field investigation.

\section{A. Site Selection}

The selection of study sites preceded the collection of objective-relevant data. Preliminary filled headwater locations were chosen from a list compiled during the course of a recent study performed by the University of Louisville Stream Institute focusing on the morphology of eastern Kentucky's headwater streams. The selection of these initial candidates was based upon their association with hollow fills discernible from aerial photography. Aerial photography was made available through the Kentucky Division of Geographic Information and viewed using ESRI's ArcGIS software. The number of prospective sites was then reduced according to the current mining status of the sites. Site status was determined using the Surface Mining Information System (SMIS) online database maintained by the Kentucky Environmental and Public Protection Cabinet's (EPPC) Division of Mine Permits (KYDMP, 2006). Sites with active mining coinciding with the date of aerial photography were disregarded in favor of those in the phases of bond release or with permits completely released and with 
presumably completed hollow fills. The process ultimately narrowed the list to two permitted sites with a total of nine hollow fills (Table II).

Streams tributary to the Tug Fork of the Big Sandy River in Pike County drain land most recently mined by Holston Mining, Inc., under permit number 898-0349 (Figure 19). Originally granted to the Eastern Coal Corporation in September of 1983 under permit number 898-0028, permission for coal extraction was transferred to Holston Mining, Inc., in February of 1992. Hollow fills of specific interest under this permit are displayed in Appendix II.

The headwater reaches of Arches Branch in Harlan County have been filled by Nally \& Hamilton Enterprises, Inc., under permit number 897-0365 (Figure 20). This permit was originally granted in December of 1994. Two hollow fills were of particular interest within the permitted area and are shown in Figure 21 and Appendix II.

\section{B. Data Collection}

Data used in the development of stream restoration considerations were primarily acquired from mining permit records made available by the Kentucky Division of Mine

TABLE II

\section{STUDY SITES}

\begin{tabular}{|c|c|c|c|c|}
\hline Permit No. & \multirow{2}{*}{ County } & $\begin{array}{c}\text { Hollow } \\
\text { Fill ID }\end{array}$ & Impacted Headwater & Date Permitted \\
\hline \multirow{4}{*}{$898-0349$} & \multirow{4}{*}{ Pike } & HF 1 & Murphys Frk. & $2 / 12 / 1987$ \\
\cline { 3 - 5 } & & HF 2 & Murphys Frk. & $1 / 20 / 1989$ \\
\cline { 3 - 5 } & & HF 4 & Mudlick Br. of Blackberry Frk. & $6 / 8 / 2000$ \\
\cline { 3 - 5 } & & HF 5 & Unnamed Tributary to Narrows Br. & $1 / 20 / 1989$ \\
\cline { 3 - 5 } & & HF 9 & Mudlick Br. of Blackberry Frk. & $10 / 12 / 1992$ \\
\cline { 3 - 5 } & & HF 10 & Narrows Br. & $10 / 12 / 1992$ \\
\cline { 3 - 5 } & HF 11 & Mudlick Br. of Pond Cr. & $1 / 29 / 1994$ \\
\hline \multirow{2}{*}{$897-0365$} & \multirow{2}{*}{ Harlan } & Arches 1 & Unnamed Tributary to Arches Br. & $12 / 22 / 1994$ \\
\cline { 3 - 5 } & & Arches 2 & Unnamed Tributary to Arches Br. & $12 / 1994$ \\
\hline
\end{tabular}




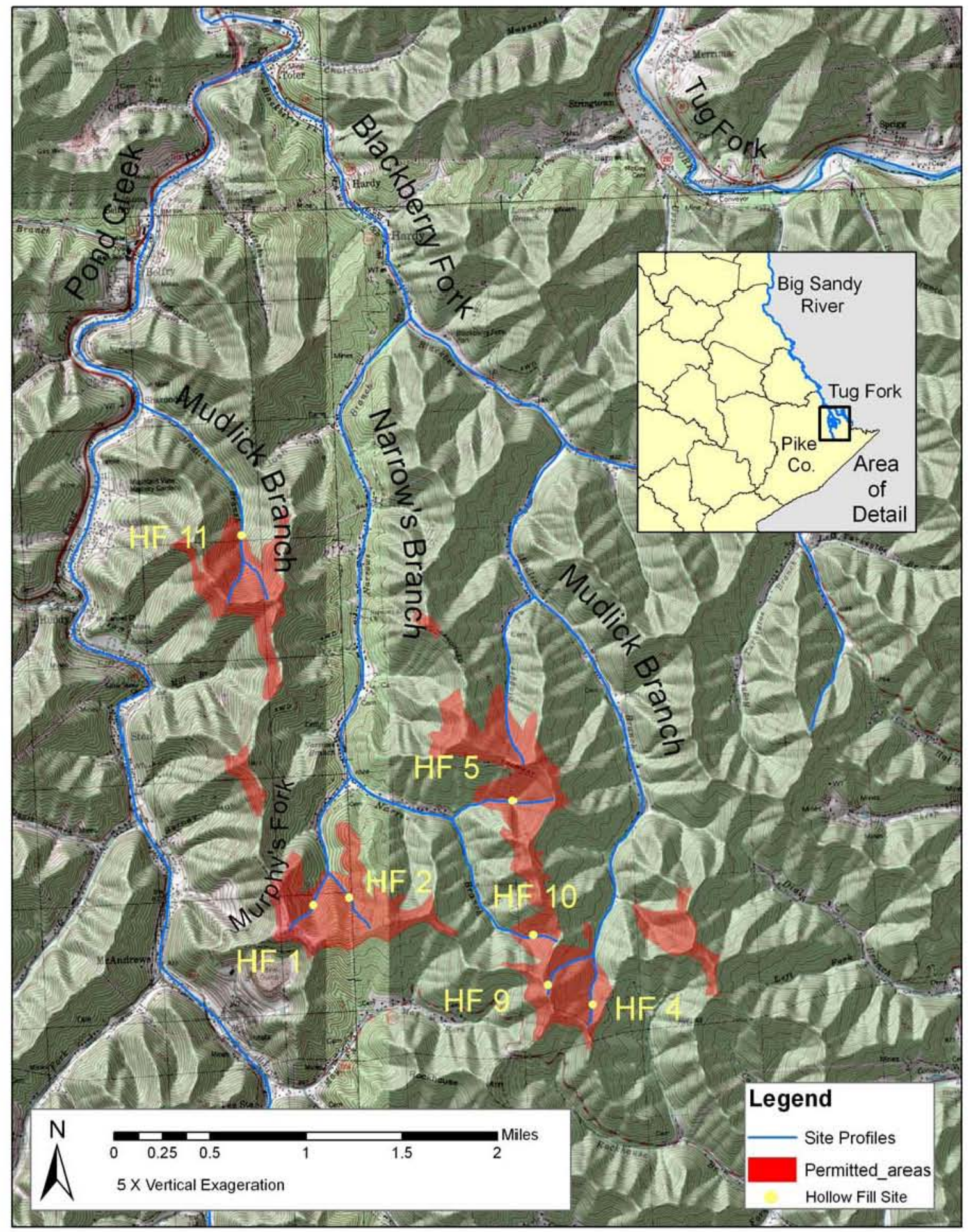

FIGURE 19 - Map of Study Hollow Fill Locations: Permit No. 898-0349 


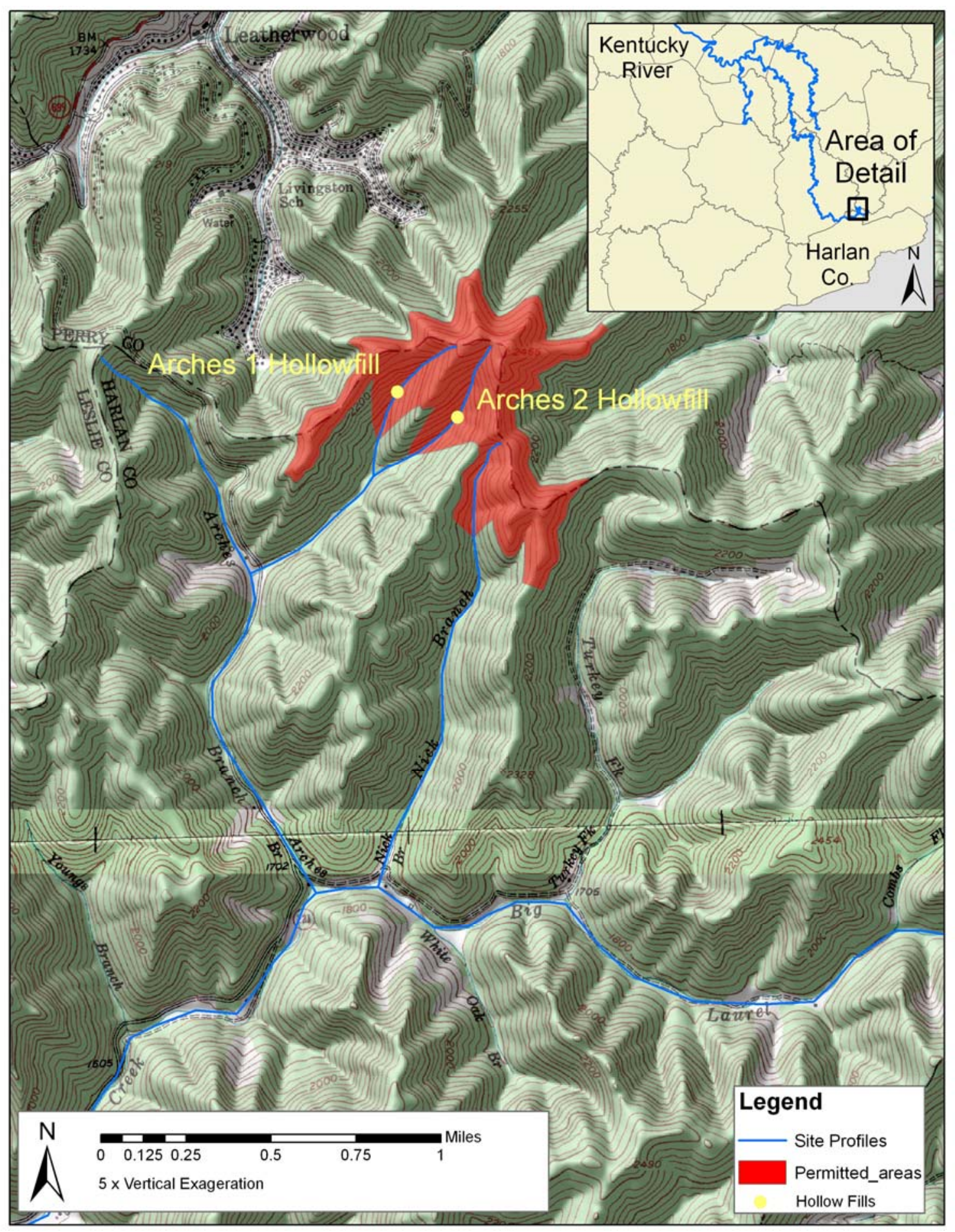

FIGURE 20 - Map of Study Hollow Fill Locations: Permit No. 897-0365 


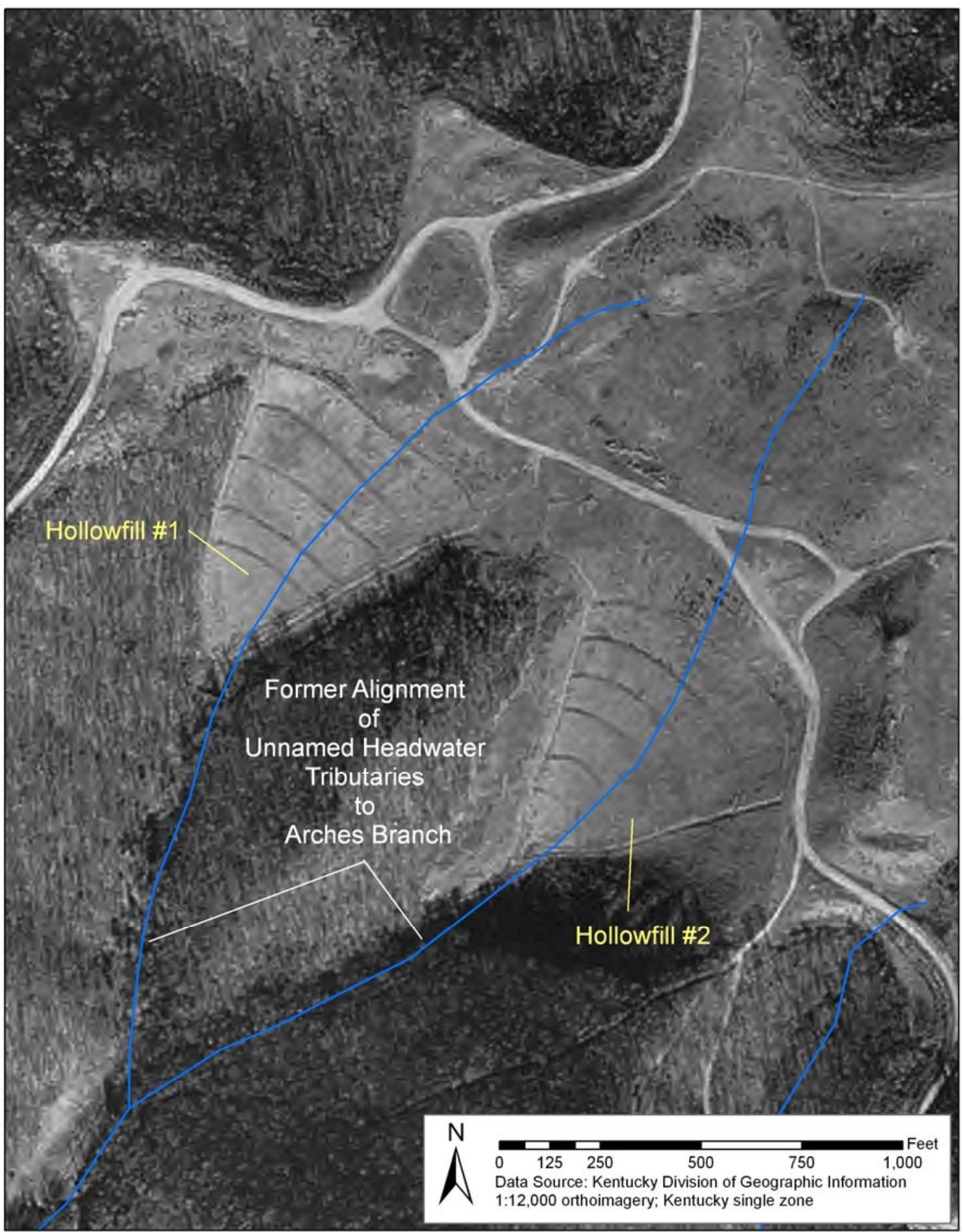

FIGURE 21 - Hollow Fills Arches 1 and Arches 2: Permit No. 897-0365 
Permits, state administrative regulations, topographic map-based longitudinal channel profiles, and field observations. Three longitudinal profiles were generated for each study site: pre-mining, post-mining plan, and post-mining as-built. The pre-mining profiles were generated with the aid of ArcGIS from 1:24,000 7.5-minute U.S. Geological Survey topographic quadrangles. The profiles generated from these quadrangles were assumed to be representative of headwater stream configurations at the time hollow fill construction began.

Post-mining plan profiles were generated using information gathered from mining permit applications approved by the Division of Mine Permits. Specifically, scaled hollow fill construction plans, complete with elevation contour lines, provided the data needed to generate profiles of the drainage ways proposed to replace the buried headwater streams. These replacement drainage ways are referred to as "diversions" in mining literature. Additional information related to hollow fill and drainage system design was also collected from these files. Only information from the most recently revised or amended edition of approved permits was extracted for analysis.

Also representing longitudinal configurations of stream diversions are postmining as-built profiles. However, as-built profiles differ from plan profiles in that they are intended to represent the post-mining drainage ways in their constructed, rather than proposed, state. Aerial photography and superimposed contour lines were used to generate approximate estimates of these profiles using ArcGIS. Because investigated longitudinal profiles are not specifically permitted, deviations between as-built and plan conditions do not necessarily reflect a lack of proper regulation or improper hollow fill construction practice. 
For a limited number of hollow fills in the study area, topographic field survey data were available from the University of Louisville Stream Institute study previously mentioned. Longitudinal profiles generated from this data were assumed to represent post-mining configurations with a greater degree of detail than those generated using the method discussed above. Survey-generated profiles not only encompass constructed diversions, but also indirectly impacted stream reaches. Additionally, survey data include stream and constructed drainage way cross-section information to supplement morphologic discussion.

Data collection continued with field visits to several of the study sites. During field reconnaissance, geomorphic processes associated with the impacted headwater streams were observed and documented with photography. Photographs taken during the previously cited study were also examined.

\section{Analysis}

The analysis of the collected data was undertaken in two basic phases. The first stage entailed a comparison of the generated longitudinal profiles to determine if geomorphically relevant discrepancies in slopes or concavity exist. Second, the processes responsible for geomorphic conditions observed during field visits were hypothesized. Both phases of the analysis highlight reasons for considering profile discrepancies or the observed processes during headwater stream restoration or re-creation efforts.

The comparison of profiles was subdivided into analyses of (1) plan versus asbuilt configurations and (2) pre-mining verses post-mining configurations. In both comparisons, profile discrepancies were detected through comparisons of plotted profiles and their associated slopes. The accuracy of the as-built profile generation method using 
aerial photography was analyzed through a comparison with survey-generated profiles assumed to be representative of the actual as-built groin ditch. The analysis of field observations was facilitated by literature review and the highly detailed survey-generated longitudinal profiles when available or applicable. 


\section{RESULTS AND DISCUSSION}

\section{A. Longitudinal Profile Comparison}

The characteristics of a stream's longitudinal profile reflect the geomorphic processes sculpting the landscape. Stream re-creation efforts addressing geomorphic processes should therefore consider such characteristics. Of particular importance is longitudinal slope which heavily influences fluvial transport sediment, a driving mechanism behind geomorphic processes.

\section{As-Built vs. Plan}

The conversion from intact, or bank, volume to loose volume of overburden may be a source of error in predicting the ultimate required size of hollow fills during the design phase. Typical percentages of expansion, or bulking factors, are often assumed in estimating the required volume of hollow fills and range from $25 \%$ to $40 \%$ for sandstone and $15 \%$ to $25 \%$ for shale after compaction (Meikle and Fincham, 1999). According to USEPA (2003), an industry average bulking factor is $25 \%$. Factors such as local overburden lithology may contribute to the variability in bulking factor estimates and the resulting lack of precise hollow fill volume predictions. The use of these approximate values by mining companies in designing fills may result in deviation of constructed fill configuration from that originally permitted. This deviation is allowed as long as it falls within a margin in which the achievement of structural stability can be proven. Specifically, under RAM \#135, the toe of a constructed hollow fill is allowed to fall between two planned points that define an acceptable range: the downstream-most point 
is established based on the maximum anticipated spoil volume, while the upstream-most point is the point above which stability cannot be achieved. Evidence of this variation is displayed through overlaying permitted design plans onto aerial photographs, as shown in Figure 22. Other overlays may be found in Appendix III.

If, during the course of construction, alteration of fill configuration beyond the margin of allowance becomes necessary, the mining company is required to submit a revised or amended design to be re-approved by the Division of Mine Permits. Overlays used in this study were taken from the final permitted revisions or amendments.

A lack of precision in predicting hollow fill configuration becomes a consideration in stream restoration because of the associated potential variability in groin ditch slope from the permitted to as-built conditions. Variation in fill volume or configuration would alter the alignment of the fill-hillside interface where groin ditches are typically constructed. In steeply sloping hollows, even a small alteration in this alignment may have a large impact on channel slope. Given only permitted hollow fill design plans, efforts to design ecologically viable and morphologically stable stream reaches as alternatives to typical groin ditches would be hampered by the inability to accurately predict this slope. The success of such efforts may be increased, however, by a knowledge of the expected range in as-built slopes on which stream construction is to be based.

The magnitude of the variation between as-built slope and plan slope was evaluated from longitudinal plots of the respective groin ditch channels. As-built profiles were generated from the intersection of superimposed topographic contour lines with groin ditches along hollow fill boundaries as displayed in geo-referenced aerial photographs. Superimposed contour lines were generated from USGS topographic maps 


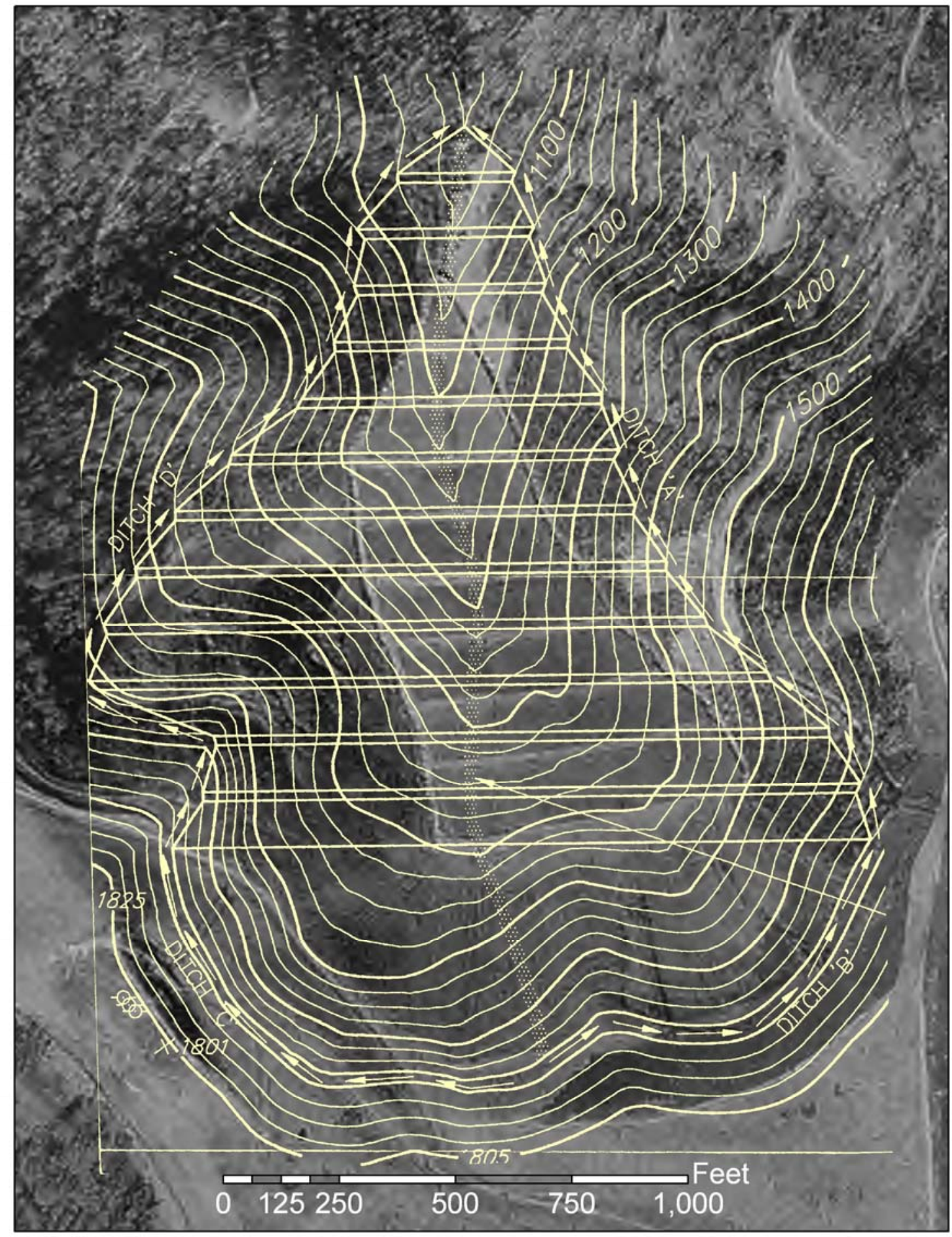

FIGURE 22 - Overlay of Permitted Hollow Fill Design Plans for HF 11 onto Aerial Photograph 
and assumed to represent the topography of hillsides adjacent to hollow fills. The accuracy of this method was checked through comparison with profiles generated from available field survey data for two hollow fills. Plan profiles were constructed from permitted hollow fill design plans. Slopes and profiles are displayed in Appendix IV with a representative displayed here as Figure 23.

Average slope was calculated (Table III) by using the downstream- and upstreammost points on the generally linear profiles. The difference of as-built average slopes from those originally anticipated ranged from approximately $-6 \%$ to $+7 \%$ with an average difference of approximately $0 \%$ and a standard deviation in the differences of approximately 4\%. Despite altered fill sizes and configurations, approximated average

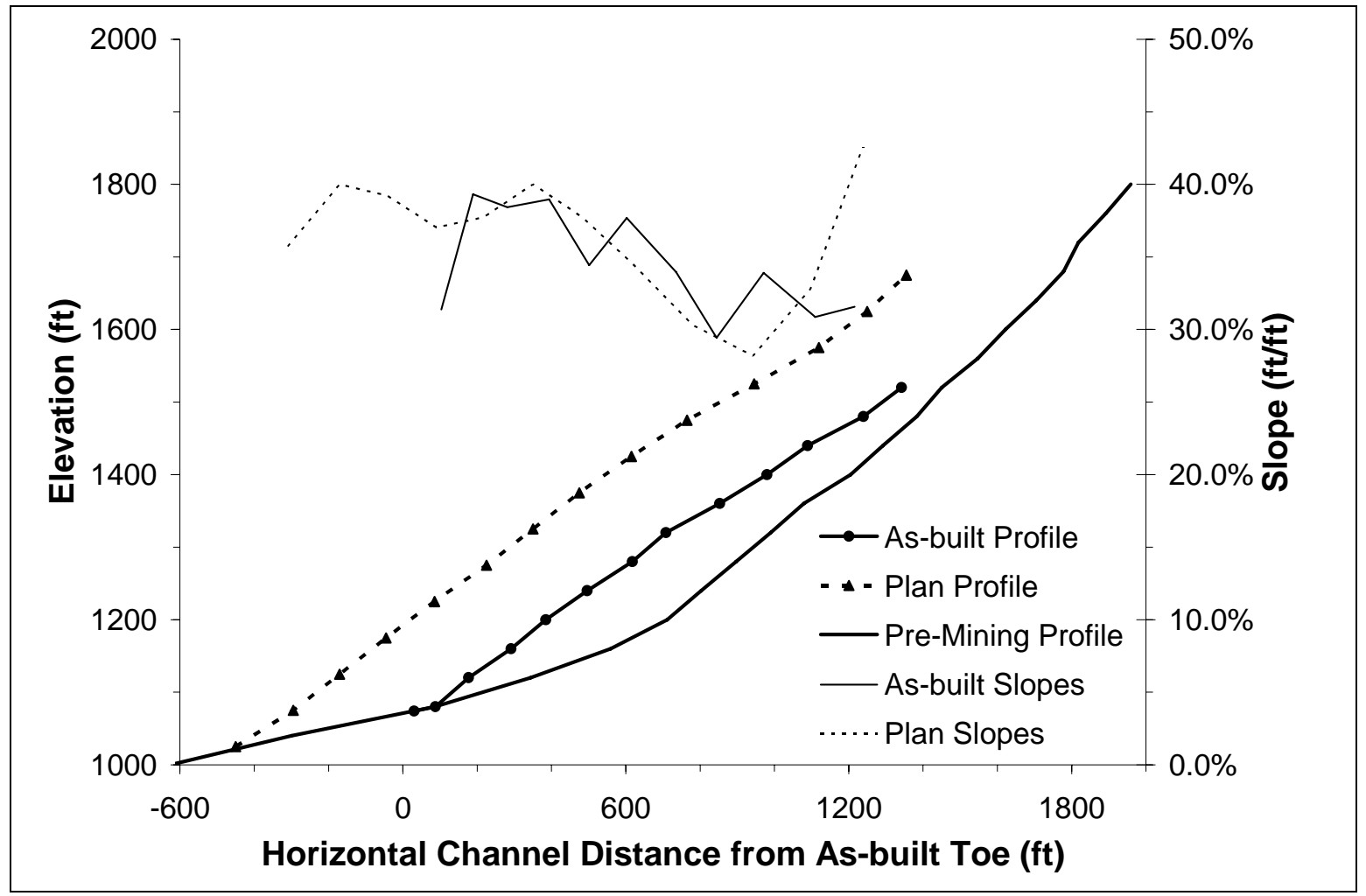

FIGURE 23 - Comparative Plot of As-Built and Plan Longitudinal Profiles and Slopes for the East Groin Ditch on HF 11 
TABLE III

PLAN AND AS-BUILT GROIN DITCH DIMENSIONS AND AVERAGE SLOPES

\begin{tabular}{|c|c|c|c|c|c|c|c|c|}
\hline \multirow{2}{*}{$\begin{array}{l}\text { Hollow } \\
\text { Fill ID }\end{array}$} & \multirow{2}{*}{$\begin{array}{l}\text { Groin } \\
\text { Ditch ID }\end{array}$} & \multicolumn{2}{|c|}{ Horizontal Length (ft) } & \multicolumn{2}{|c|}{$\begin{array}{l}\text { Change in } \\
\text { Elevation (ft) }\end{array}$} & \multicolumn{2}{|c|}{ Average Slope (ft/ft) } & \multirow{2}{*}{$\begin{array}{c}\text { Slope } \\
\text { Difference } \\
\text { from } \\
\text { Plan (ft/ft) }\end{array}$} \\
\hline & & Plan & As-Built & Plan & As-Built & Plan & As-Built & \\
\hline \multirow{2}{*}{ HF1 } & $E$ & 1660 & 1486 & 550 & 534 & $33 \%$ & $36 \%$ & $-3 \%$ \\
\hline & $\mathrm{W}$ & NA & NA & 550 & $\mathrm{NA}$ & NA & NA & NA \\
\hline \multirow{2}{*}{ HF2 } & $E$ & 1610 & 1578 & 575 & 633 & $36 \%$ & $40 \%$ & $-4 \%$ \\
\hline & W & $\mathrm{NA}$ & $\mathrm{NA}$ & 550 & $\mathrm{NA}$ & NA & $\mathrm{NA}$ & NA \\
\hline \multirow{2}{*}{ HF4 } & $E$ & $\mathrm{NA}$ & NA & 300 & NA & NA & NA & NA \\
\hline & W & 820 & 881 & 300 & 260 & $37 \%$ & $29 \%$ & $7 \%$ \\
\hline \multirow{2}{*}{ HF5 } & $\mathrm{N}$ & 1530 & 1360 & 500 & 470 & $33 \%$ & $35 \%$ & $-2 \%$ \\
\hline & $\mathrm{S}$ & 1490 & 1669 & 500 & 590 & $34 \%$ & $35 \%$ & $-2 \%$ \\
\hline \multirow{2}{*}{ HF9 } & $\mathrm{N}$ & 1425 & 1406 & 475 & 460 & $33 \%$ & $33 \%$ & $1 \%$ \\
\hline & $\mathrm{S}$ & 1250 & 1232 & 475 & 460 & $38 \%$ & $37 \%$ & $1 \%$ \\
\hline \multirow{2}{*}{ HF10 } & $\mathrm{N}$ & 1185 & 1153 & 425 & 333 & $36 \%$ & $29 \%$ & $7 \%$ \\
\hline & $\mathrm{S}$ & 1330 & 1262 & 425 & 373 & $32 \%$ & $30 \%$ & $2 \%$ \\
\hline \multirow{2}{*}{ HF11 } & $E$ & 1805 & 1343 & 650 & 446 & $36 \%$ & $33 \%$ & $3 \%$ \\
\hline & $\mathrm{W}$ & 2035 & 1313 & 650 & 331 & $32 \%$ & $25 \%$ & $7 \%$ \\
\hline \multirow{2}{*}{ Arches1 } & $\mathrm{N}$ & 950 & 729 & 320 & 260 & $34 \%$ & $36 \%$ & $-2 \%$ \\
\hline & $\mathrm{S}$ & 945 & 650 & 320 & 260 & $34 \%$ & $40 \%$ & $-6 \%$ \\
\hline \multirow{2}{*}{ Arches2 } & $\mathrm{N}$ & 940 & 690 & 320 & 260 & $34 \%$ & $38 \%$ & $-4 \%$ \\
\hline & $\mathrm{S}$ & 945 & 675 & 320 & 260 & $34 \%$ & $39 \%$ & $-5 \%$ \\
\hline & & & & \multicolumn{2}{|c|}{ Average } & $34 \%$ & $34 \%$ & $0 \%$ \\
\hline & & & & \multicolumn{2}{|c|}{ Standard Deviation } & $2 \%$ & $4 \%$ & $4 \%$ \\
\hline
\end{tabular}

slopes are not significantly different based on the mean and standard deviation of their differences $(\alpha=0.05)$; evidence is not sufficient to reject the hypothesis that the average as-built and plan slopes are the same assuming a normal distribution of their differences. With $99 \%$ confidence, differences in slopes can be expected to fall within the range of approximately $-3.4 \%$ to $+3.4 \%$.

As can be seen in the figures of Appendix IV, both plan and constructed groin ditch profiles are generally linear in nature. Assuming that the associated uniformity of the slopes of these profiles is the intention of their design, the average slopes of Table III may be a fair approximation. However, these generalized slopes overlook the possibility 
of significant local variations along the profile. To address this issue, slopes were calculated using a two-segment moving average method to smooth over possibly erroneous extremes while still detecting localized values. The spacing of available profile data points resulted in localized slopes averaged over distances comparable to the approximately 100-foot spacing of hollow fill terraces. Local differences were calculated at $20 \%, 40 \%$, and $80 \%$ of the total groin ditch lengths.

Figure 24 summarizes plan and as-built slopes, respectively, for normalized ditch lengths. A visual comparison of these plots reveals generally increased variability from linearity of local as-built slopes along the length of a given groin ditch; as-built slopes seem to be less longitudinally uniform than plan slopes which correspond to permitted conditions. This longitudinal fluctuation is reflected in localized slope differences between as-built and plan profiles (Figure 25).

With the exception of a noticeably decreased range at around $40 \%$ of the normalized groin ditch length, discrepancy from the plan local slopes appears to be poorly correlated with position. Overlooking any such correlation and considering the entire set of local discrepancies, values ranged from approximately $-15 \%$ to $+24 \%$ (absolute slope). The bulk of the total data set, as described by its first and third quartiles, fell between approximately $-4 \%$ and $+7 \%$. This apparent condition was not recognized in the analysis of overall average slopes.

Another trend that is consistent from permitted to constructed conditions is the concave nature of the profiles at the fill toes. This general concavity is indicated by the large number of positively sloping initial line segments of Figure 24. The upstream segments of constructed ditches, on the other hand, exhibit the opposite tendency: the 
(a)

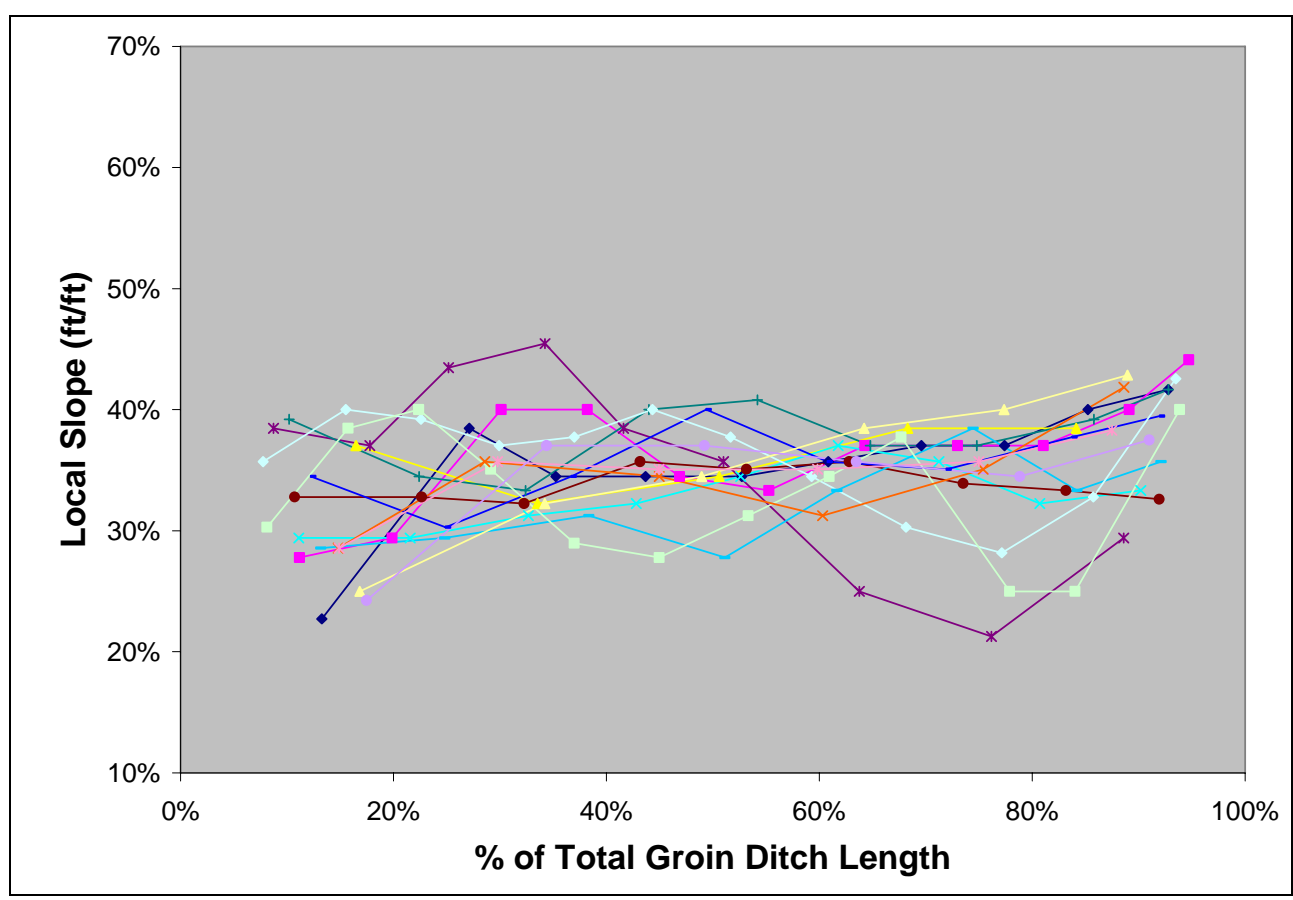

(b)

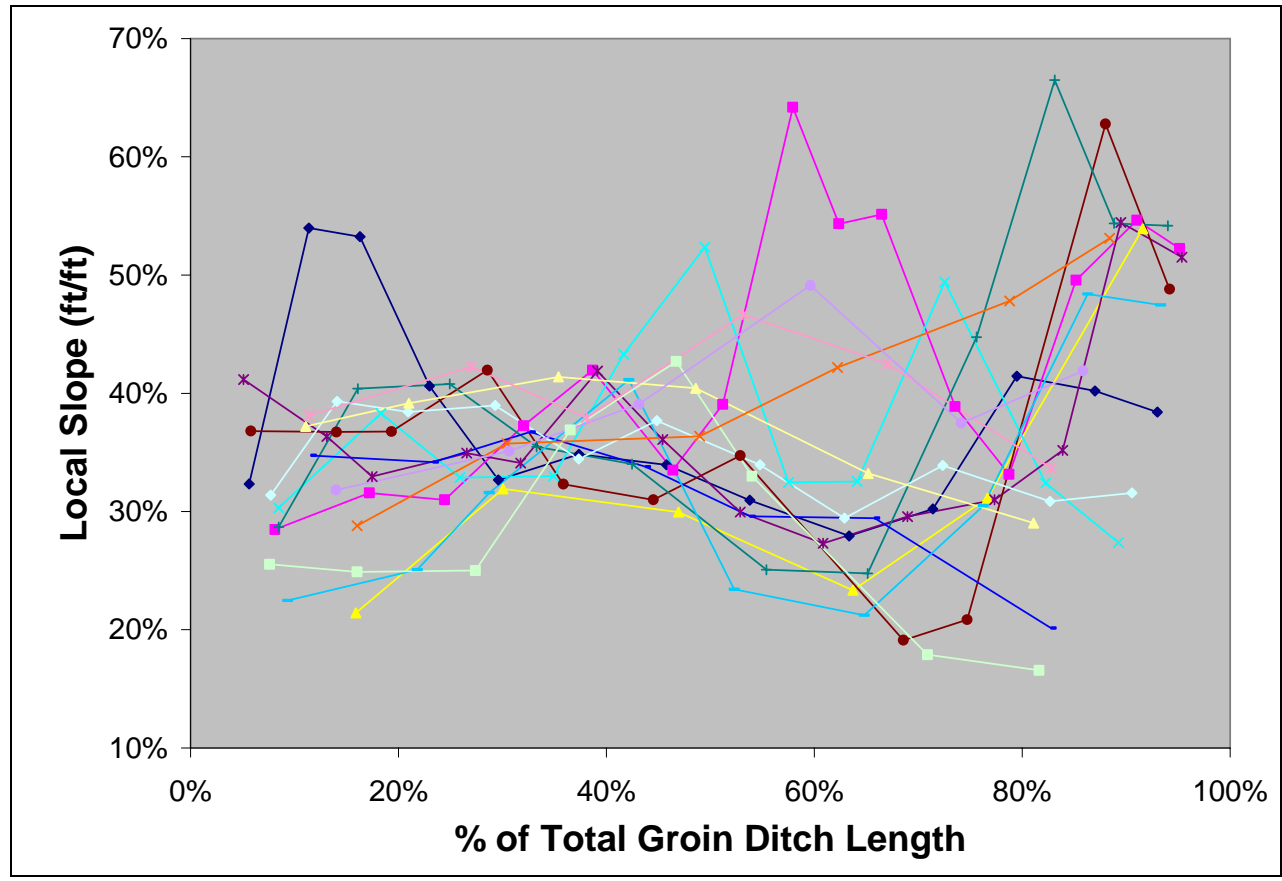

\begin{tabular}{|cccc|}
\hline$\rightarrow$ HF1 E & - HF2 E & HF4 W & HF5 N \\
- HF5 S & - HF9 N & HF9S & - HF10 N \\
HF10S & HF11 E & HF11 W & Arches1 N \\
- Arches1S & Arches2 N & Arches2 S & \\
\hline
\end{tabular}

FIGURE 24 - Local Slopes of (a) Plan and (b) As-Built Groin Ditch Profiles; 0\% of Total Groin Ditch Length Corresponds to Hollow Fill Toe 


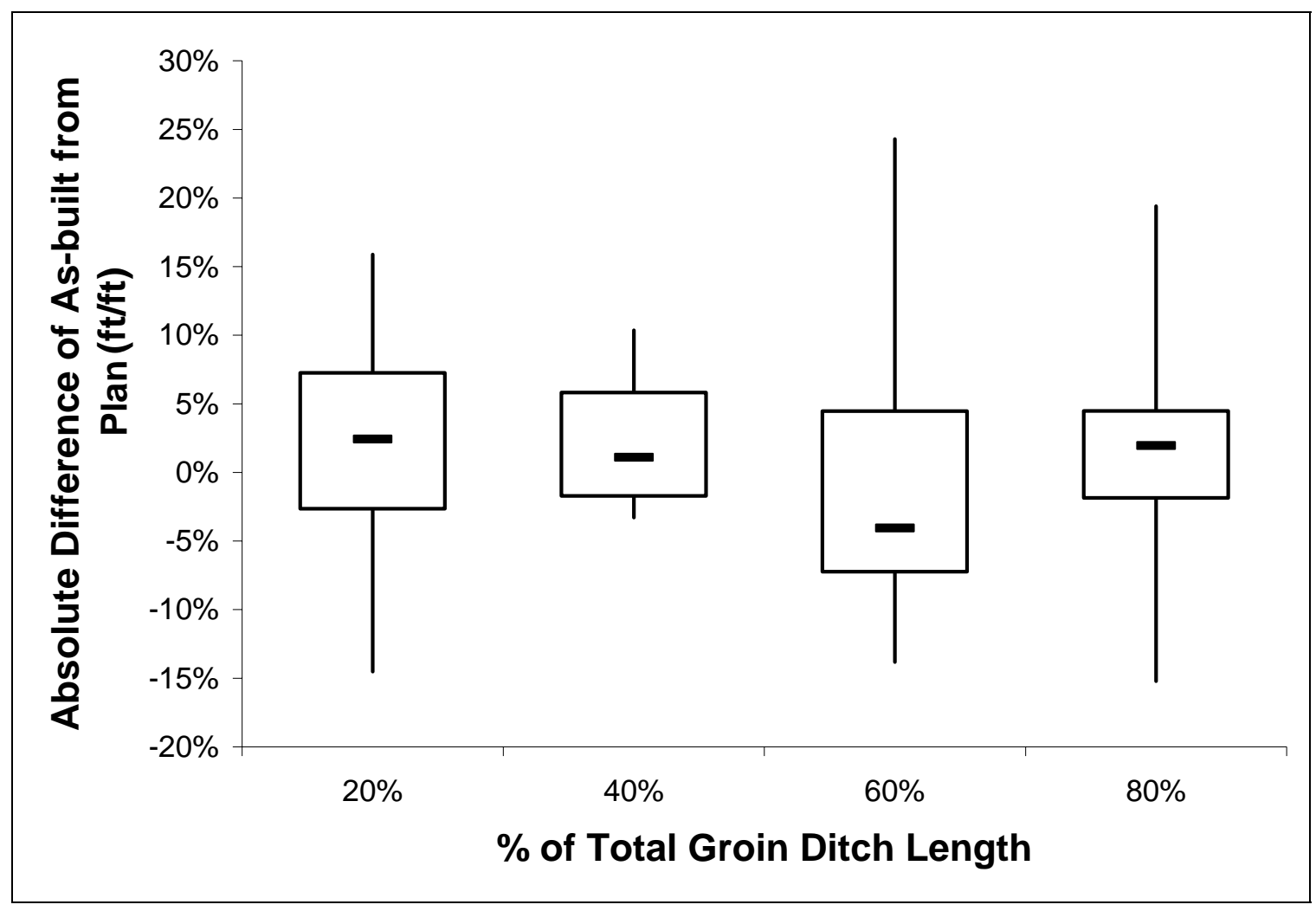

FIGURE 25 - Comparison of Local Slopes for As-Built and Plan Groin Ditch Profiles

large number of negatively sloping terminal line segments of Figure $24 \mathrm{a}$ indicates that the upstream-most region of constructed ditches are convex.

A possible explanation for the increased variability observed in as-built slopes may be tied to inconsistencies between actual topography and that for which hollow fills were designed. Also, adjustment of fill size may result in the need to accommodate smallscale variations in valley topography at the fill-hillside interface. Much of this local variability may be unrelated to longitudinal position with the exception of the possible groin ditch concavity at the toe of both the permitted and the constructed fills and possible convexity at the upstream portion of constructed groin ditches. The toe concavity and upstream convexity may be related to the footslope concavity and nose 
convexity of the natural hillsides, but the small sample size of this study prohibits any further investigation of that possibility.

The most significant source of error in the calculation of slopes for plan profiles may be associated with measurements of small-sized, large-scale plan drawings lacking detail. Yet another source of error associated with plan profiles may be the decision to ignore the short small-slope channel sections drawn to coincide with terrace benches. This decision was made due to the potential for error in measuring these small features and the lack of field evidence supporting such a stepped profile.

Potential sources of error associated with as-built profiles may also be of concern. Of most significance may be the resolution of aerial photography. Difficulty in identifying the head, channel, and termination of groin ditches led to error in calculated slope values. Errors may also have developed from the scale of the 40 -foot interval contour lines and geographical coincidence between these lines and aerial photographs onto which they were overlaid. To lessen the magnitude of errors associated with as-built profile generation, slopes were calculated using a two-segment moving average.

The method of as-built profile generation from aerial photography was tested for accuracy through comparison with a limited amount of data collected from total station field surveys. Surveyed longitudinal profiles are significantly more detailed and accurate than their aerial photography-derived counterparts because they are composed of large numbers of physically collected data points. Of these numerous data points, only those that closely corresponded longitudinally with the few data points available from the aerial photograph analysis were chosen for comparison. Using these points, local slopes of the surveyed profiles were calculated with the two-segment moving average technique for 
consistency. The percent difference of aerial photograph-generated slopes from those of the survey represents mesurement error. This error was found to correlate with aerial photograph-generated slopes, indicating bias toward extreme values; relatively high aerial photograph-generated slopes correspond to large positive error, and relatively low aerial photograph-generated slopes correspond with large negative error (Figure 26).

The correlation between error and aerial photograph-generated as-built slope values may be more accurately defined with additional survey data. With such data, measurement bias of the aerial photograph method could be more truthfully determined and corrected for. The lack of extensive survey data thwarted efforts to correct for bias in the method-generated slopes of this study.

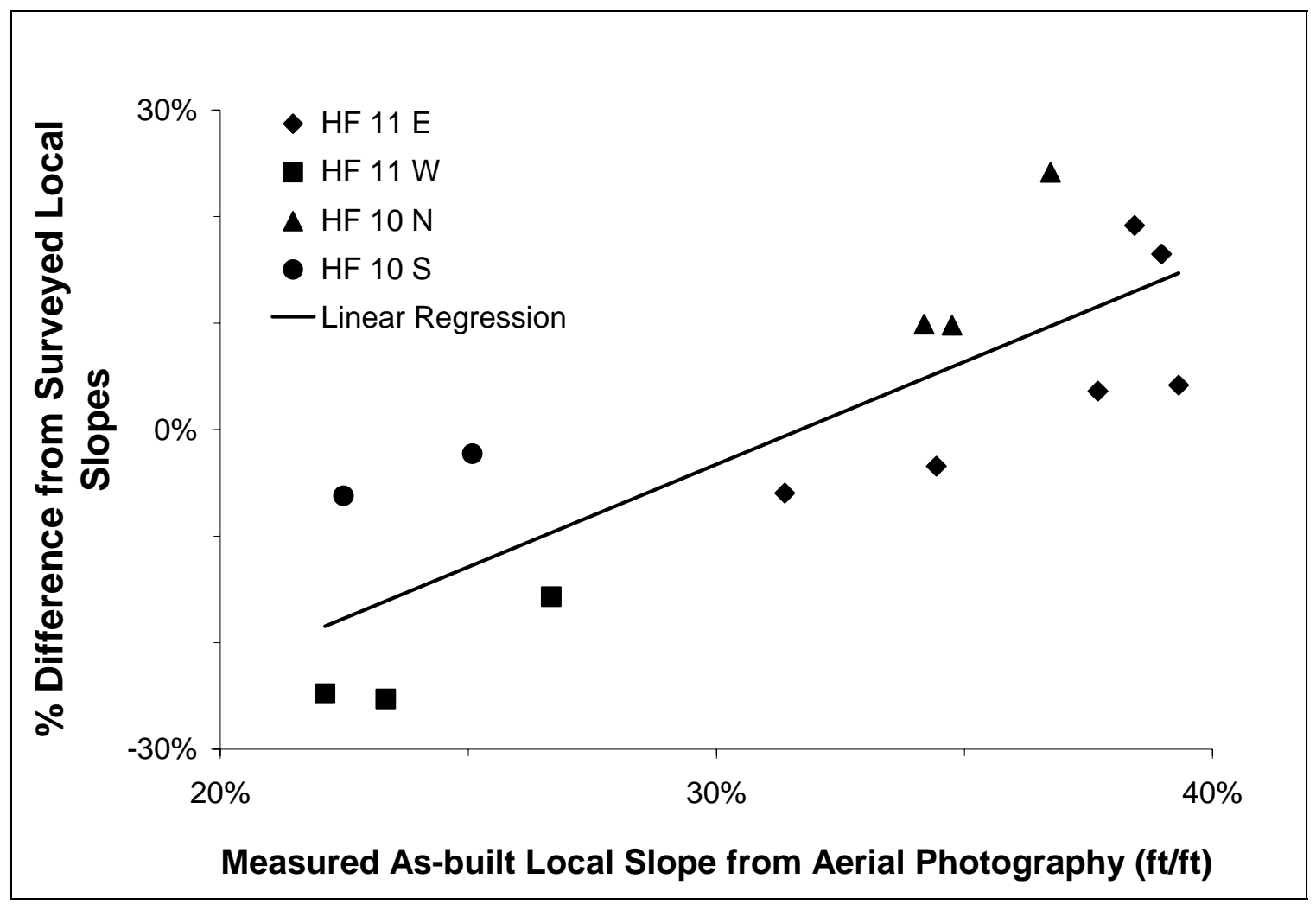

FIGURE 26 - Correlation of Error in Measured As-Built Local Slopes (Percent Difference from Actual Surveyed) with Measured As-Built Local Slopes 
The findings regarding discrepancies between plan and as-built slopes may be helpful in stream restoration efforts to the extent that they give a general idea of the magnitude of the variability to be expected between slopes of permitted hollow fill configurations and those actually constructed. Average as-built slopes may be expected to be very close to those of design plans (within $\pm 7 \%$ ), but local variations along a given as-built profile may be greater than planned and large local slope discrepancies (as great as $\pm 24 \%$ ) may exist. Further research on a larger number of hollow fills using more intensive methods of as-built slope determination, such as field surveying, may better define this potential range.

\section{Pre-mining vs. Post-mining}

Post-mining groin ditch longitudinal profiles vary dramatically from the profile of the preexisting headwater stream. Bulldozers preempt geomorphic processes in setting the slope and convexity of these newly imposed profiles. However, such alterations may be only of short-term stability due to the persistence of precipitation, gravity, and weathering in determining the sediment load, sediment size, and discharge that are the main factors controlling channel gradient (Knighton, 1998). Hollow fill designs that consider the influence of these factors on channel form will promote the long-term morphologic stability of the ditches. Geomorphic implications may be most significant at hollow fill toes or former sediment pond embankments, where slope discrepancies are greatest.

A comparison of plotted pre- and post-mining longitudinal profiles reveals the dissimilarities resulting from hollow fill construction. Stream profiles previous to hollow fill construction were generated from 1:24,000, 7.5-minute USGS topographic maps that 
predate mining operations pertinent to this study. Post-mining groin ditch profiles (e.g., Figure 27) were generated from aerial photography overlain with contour lines in ArcGIS.

Most apparent in the comparison of pre- to post-mining longitudinal profiles is the loss of overall profile concavity. The primarily uniformly sloping groin ditch profiles stand in stark contrast to the generally concave profiles of the original headwater streams. With the exception of small-scale convexities, original slope generally increases in the upstream direction indicating upward concavity. This trend continues upstream until slopes begin to flatten near the ridge. The small-scale convexities are most likely a result of the spatially varying substrate, tectonic uplift, and bedrock interaction characteristic of

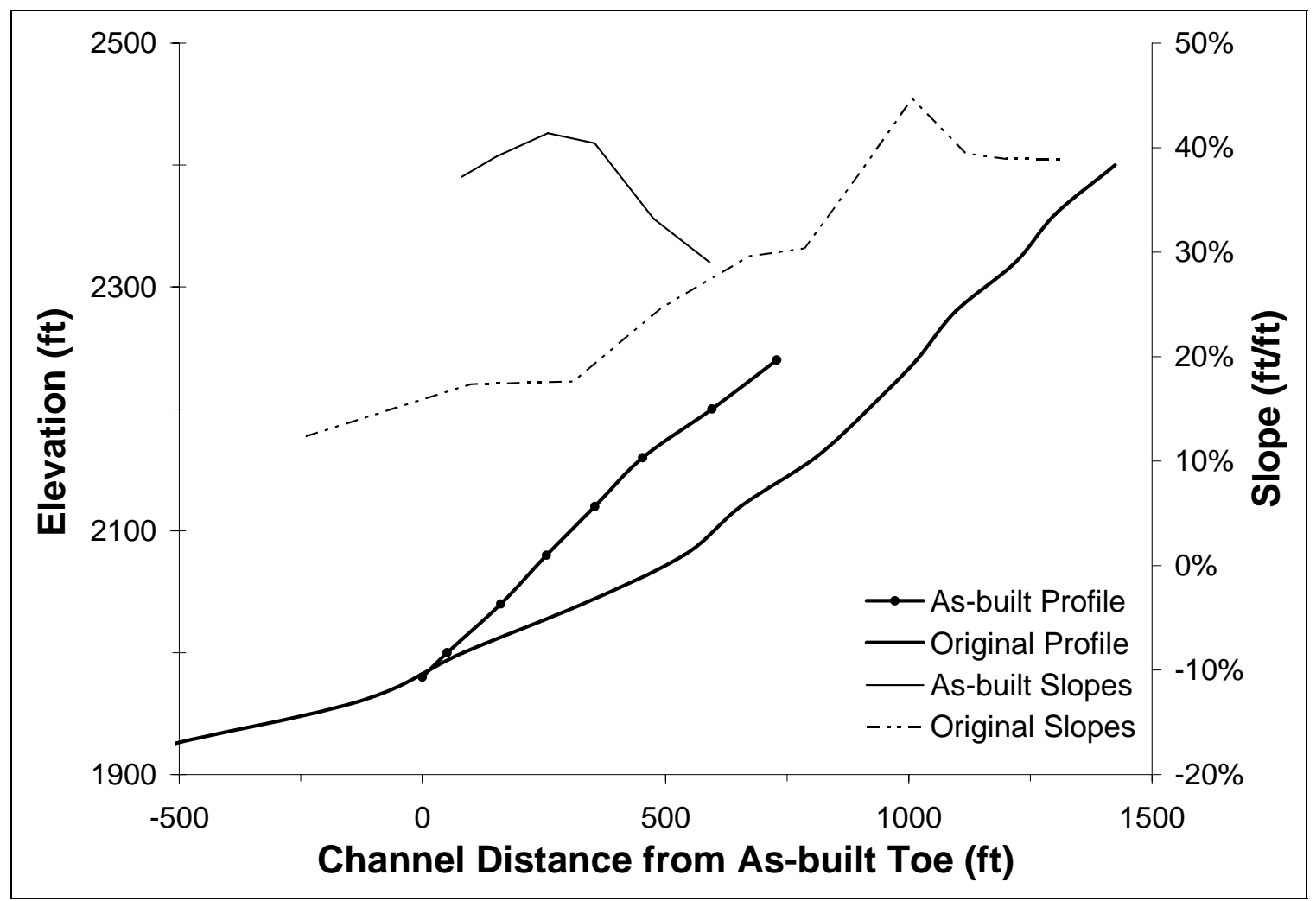

FIGURE 27 - Comparative Plot of Pre-Mining Headwater Stream and Groin Ditch Longitudinal Profiles for Arches 1 
headwater streams (Wohl, 2000). Post-mining groin ditch slope, on the other hand, appears to remain relatively consistent in the upstream direction, or it exhibits random variation.

The transition from anthropogenic-imposed to geomorphic-imposed slopes occurs at the toe of hollow fills. Because natural channel gradient tends to decrease in the downstream direction, slope discrepancies are generally highest at this location (Table IV).

On average, groin ditch slopes were found to be $122 \%$ higher than original slopes measured at the location of the as-built hollow fill toe. Stream restoration efforts should

\section{TABLE IV}

COMPARISON OF APPROXIMATE ORIGINAL AND GROIN DITCH LOCAL SLOPES AT HOLLOW FILL TOES

\begin{tabular}{|c|c|c|c|c|}
\hline $\begin{array}{c}\text { Hollow Fill } \\
\text { ID }\end{array}$ & $\begin{array}{l}\text { Original } \\
\text { Slope (ft/ft) }\end{array}$ & Groin Ditch ID & $\begin{array}{l}\text { Groin Ditch } \\
\text { Slope (ft/ft) }\end{array}$ & $\begin{array}{l}\% \text { Difference } \\
\text { from Original }\end{array}$ \\
\hline \multirow{2}{*}{ HF1 } & \multirow{2}{*}{$14 \%$} & $E$ & $32 \%$ & $125 \%$ \\
\hline & & W & NA & NA \\
\hline \multirow{2}{*}{ HF2 } & \multirow{2}{*}{$12 \%$} & $E$ & $28 \%$ & $132 \%$ \\
\hline & & $W$ & NA & NA \\
\hline \multirow{2}{*}{ HF4 } & \multirow{2}{*}{$11 \%$} & $E$ & NA & NA \\
\hline & & W & $21 \%$ & $89 \%$ \\
\hline \multirow{2}{*}{ HF5 } & \multirow{2}{*}{$15 \%$} & $\mathrm{~N}$ & $30 \%$ & $107 \%$ \\
\hline & & $\mathrm{S}$ & $41 \%$ & $182 \%$ \\
\hline \multirow{2}{*}{ HF9 } & \multirow{2}{*}{$22 \%$} & $\mathrm{~N}$ & $37 \%$ & $70 \%$ \\
\hline & & $S$ & $29 \%$ & $32 \%$ \\
\hline \multirow{2}{*}{ HF10 } & \multirow{2}{*}{$12 \%$} & $\mathrm{~N}$ & $35 \%$ & $196 \%$ \\
\hline & & $\mathrm{S}$ & $22 \%$ & $92 \%$ \\
\hline \multirow{2}{*}{ HF11 } & \multirow{2}{*}{$12 \%$} & $E$ & $31 \%$ & $152 \%$ \\
\hline & & W & $26 \%$ & $105 \%$ \\
\hline \multirow{2}{*}{ Arches1 } & \multirow{2}{*}{$17 \%$} & $\mathrm{~N}$ & $37 \%$ & $114 \%$ \\
\hline & & $S$ & $29 \%$ & $66 \%$ \\
\hline \multirow{2}{*}{ Arches2 } & \multirow{2}{*}{$12 \%$} & $\mathrm{~N}$ & $38 \%$ & $208 \%$ \\
\hline & & $S$ & $32 \%$ & $157 \%$ \\
\hline & & & Average & $122 \%$ \\
\hline & & & $\begin{array}{l}\text { Standard } \\
\text { Deviation }\end{array}$ & $50 \%$ \\
\hline
\end{tabular}


incorporate consideration for this increase and the possibility of morphologic instability within groin ditches upstream and the stream channel downstream of the transition. Furthermore, due to their downstream-most location, these reaches convey relatively more runoff from a larger catchment area than reaches further upstream. Like increased slopes, the higher discharge rates at these reaches may increase a stream's ability to transport sediment and, subsequently, alter its morphology and exacerbate the potential for altered physical evolution.

Original slope and concavity are generally a result of geomorphic processes responding to increasing discharge and decreasing particle size in the downstream direction (Leopold et al., 1992). The persistence of geomorphic processes will cause the evolution of the post-mining channels despite the presence of armored groin ditches. However, groin ditch profiles may not return to the exact form of their pre-mining predecessor because of alterations in discharge and sediment supply incurred through mining practices. A specific attributable practice may be the subdivision of headwater drainage area resulting from the construction of two groin ditches. The area previously drained by a single main channel is drained by twin channels, resulting in a potentially reduced discharge conveyed by a given groin ditch. Additional alterations may result from changes to land cover characteristics that control overland flow and soil erosion, changes to catchment topography that also affect overland flow, changes to channel substrate, and the introduction of an altered source of sediment in the form of the hollow fill and backfill areas. While such alterations should be of concern in comparing pre- and post-mining profiles, the key consideration remains: post-mining profiles are not set by geomorphic processes and morphologic evolution is a potential repercussion. 


\section{B. Field Observations}

After a mountaintop is mined and its valleys filled, the topography and land surface are left in a radically altered state subject to correspondingly altered geomorphic processes. Newly imposed channel slopes, convexities, morphology, substrate, hydrology, and other factors of geomorphic influence in the mined and filled headwater stream catchment may influence several examples of active landform evolution observed through field examination.

\section{Geomorphic Setting}

In addition to imposed groin ditch longitudinal profiles, other aspects of the postmining physical setting may govern geomorphic processes. Field examination revealed several of these physical aspects associated with groin ditches, rock check dams, and channels reconstructed through reclaimed sediment pond areas. These in-stream structures and diversions were observed to present morphology differing drastically from that of the typical native headwater channel. Altered groin ditch longitudinal profiles were accompanied by differences in bed substrate, longitudinal slope, and cross-sectional geometry of reconstructed reaches downstream of the hollow fill. The physical characteristics of stream reaches adjacent to those directly impacted were observed for purposes of comparison. These adjacent reaches may reflect geomorphic processes influenced by in-stream structures and reconstructed channels.

Groin ditches observed in this study were constructed along the interface of the fill and the natural hillside and had relatively uniform morphology along their lengths (see surveyed cross section in Figure 28). Groin ditches are designed for a single flow rate despite a continuously varying drainage area along their lengths. The substrate of 
groin ditches is predominately large boulders of blasted sandstone or shale (Figure 29). Interstices of the boulder lining are commonly filled with fragments produced by the weathering of these rocks (Figure 30). In accordance with the longitudinal profile analysis findings, slopes were observed to be relatively constant with small-scale variations.

Downstream of the hollow fill, the morphological setting is also directly altered from its pre-mining condition due to the construction of rock check dams (Figure 31) and sediment ponds within the headwater stream channel. Rock check dams remain in place after the completion of construction, while sediment ponds are only intended to be temporary diversions. In the observed sites, rock check dams remained along with remnants of sediment pond embankments and impounded material.

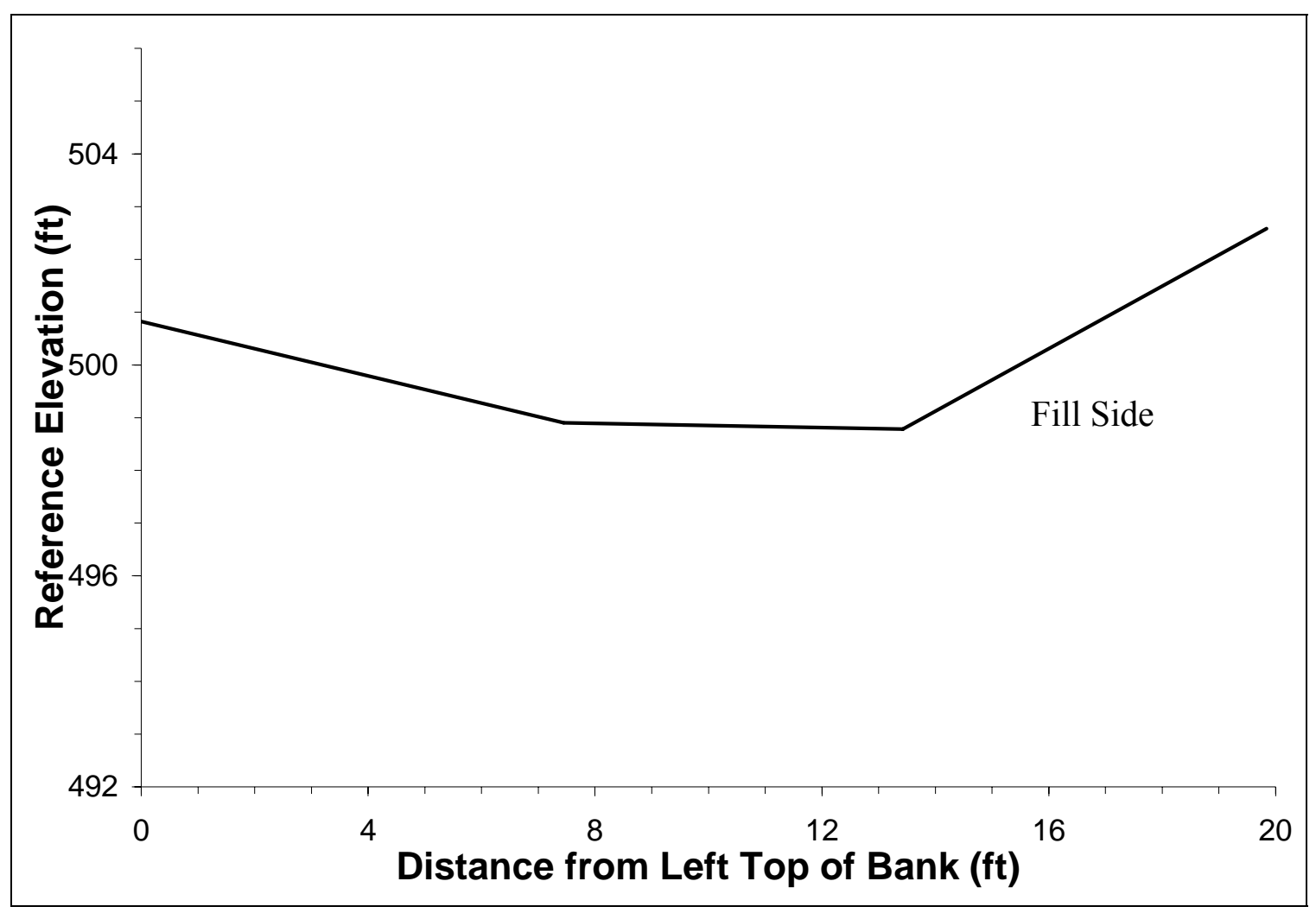

FIGURE 28 - Typical Surveyed Groin Ditch Cross Section (HF 11) 


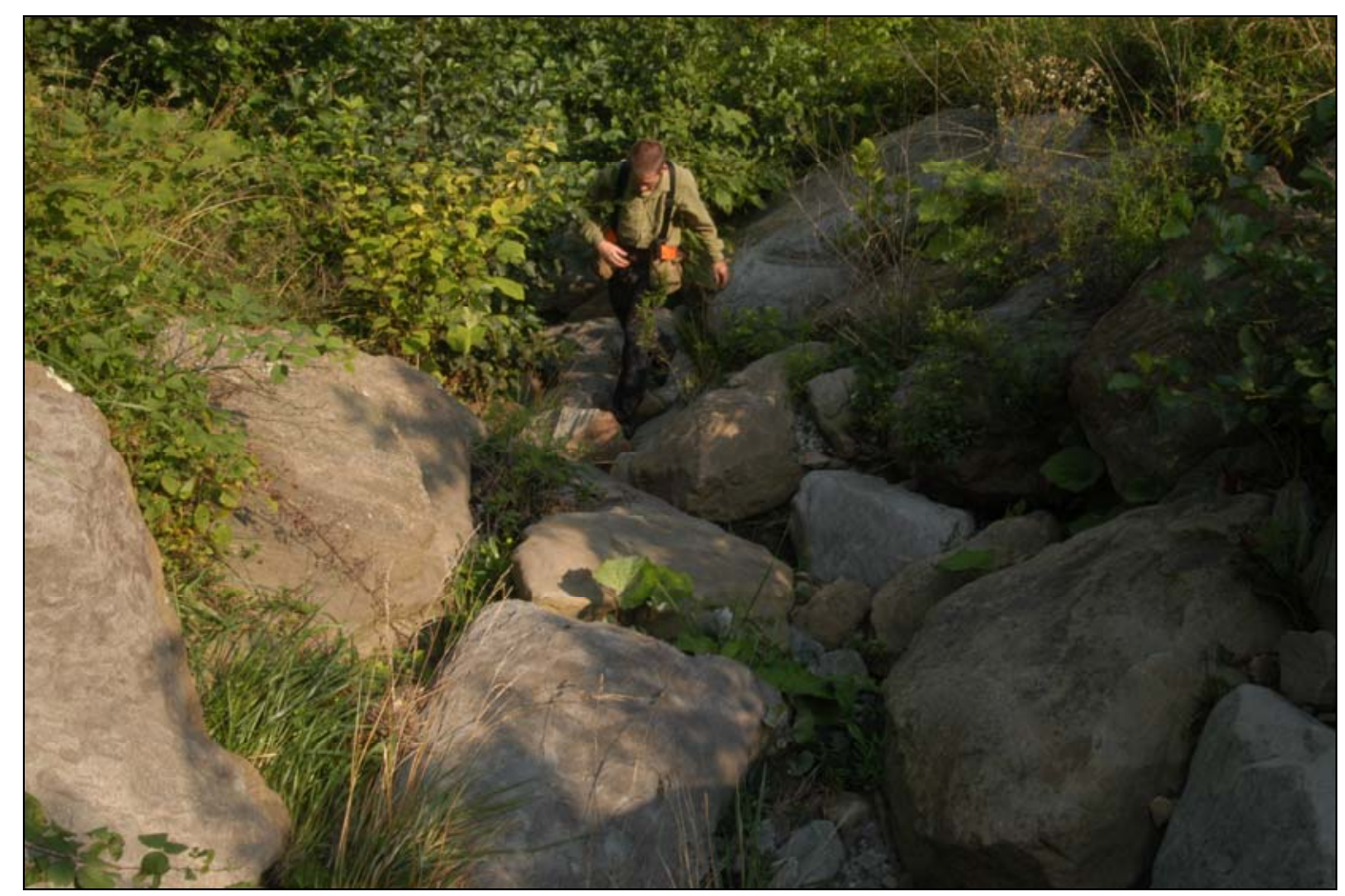

FIGURE 29 - Typical Boulder Substrate Lining Groin Ditches (HF 10 on Permit No. 898-0349)

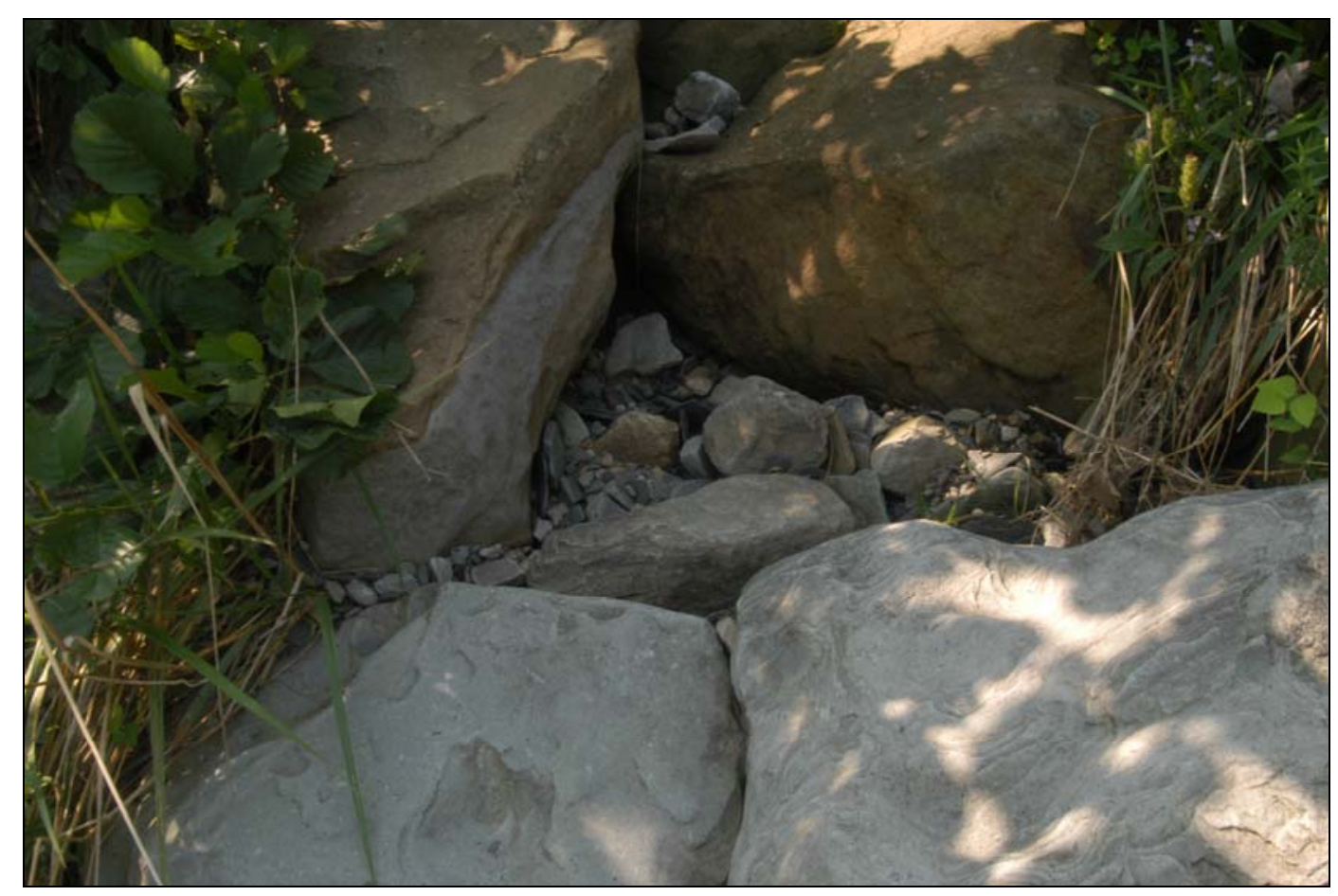

FIGURE 30 - Interstitial Spaces of Groin Ditch Lining Filled with Products of Weathering Rock (HF 10 on Permit No. 898-0349) 


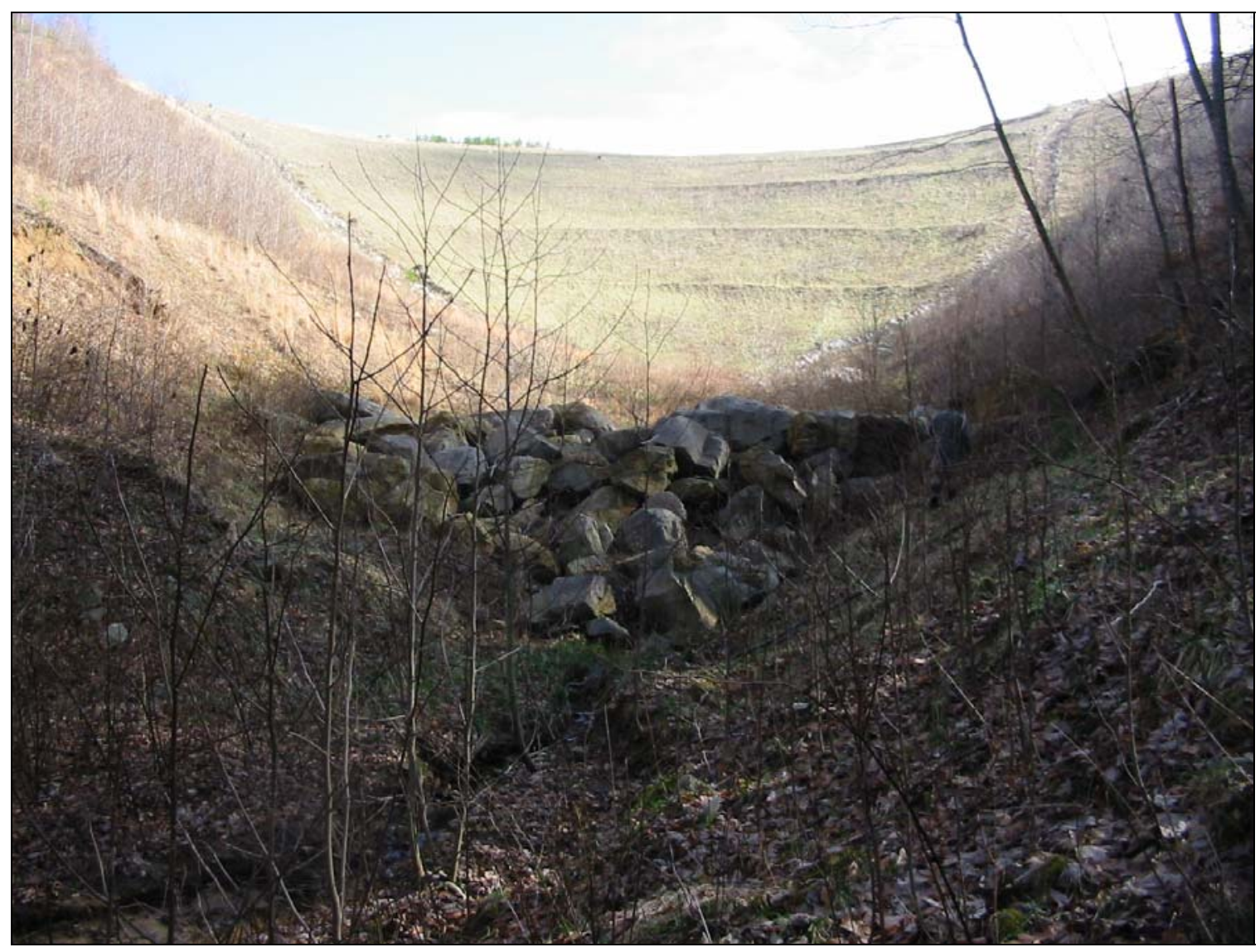

FIGURE 31 - Typical Rock Check Dam Structure (Arches 2)

The pond areas observed in the field and represented here were inactive. Rather than an impoundment of water, ponds displayed evidence of dewatering, reworking of the collected sediment wedge, and reconstruction of a drainage way through the former pond area. In the surveyed longitudinal stream profile (Figure 32), the pond area is represented by a profile convexity. This hump is a result of the reconstruction of the drainage way across the sediment wedge retained by the pond. Morphology of reconstructed drainage ways differed significantly from proximal reaches not directly impacted. As can be seen in Figure 33, channels were often reconstructed as straight, rip-rapped ditches. 


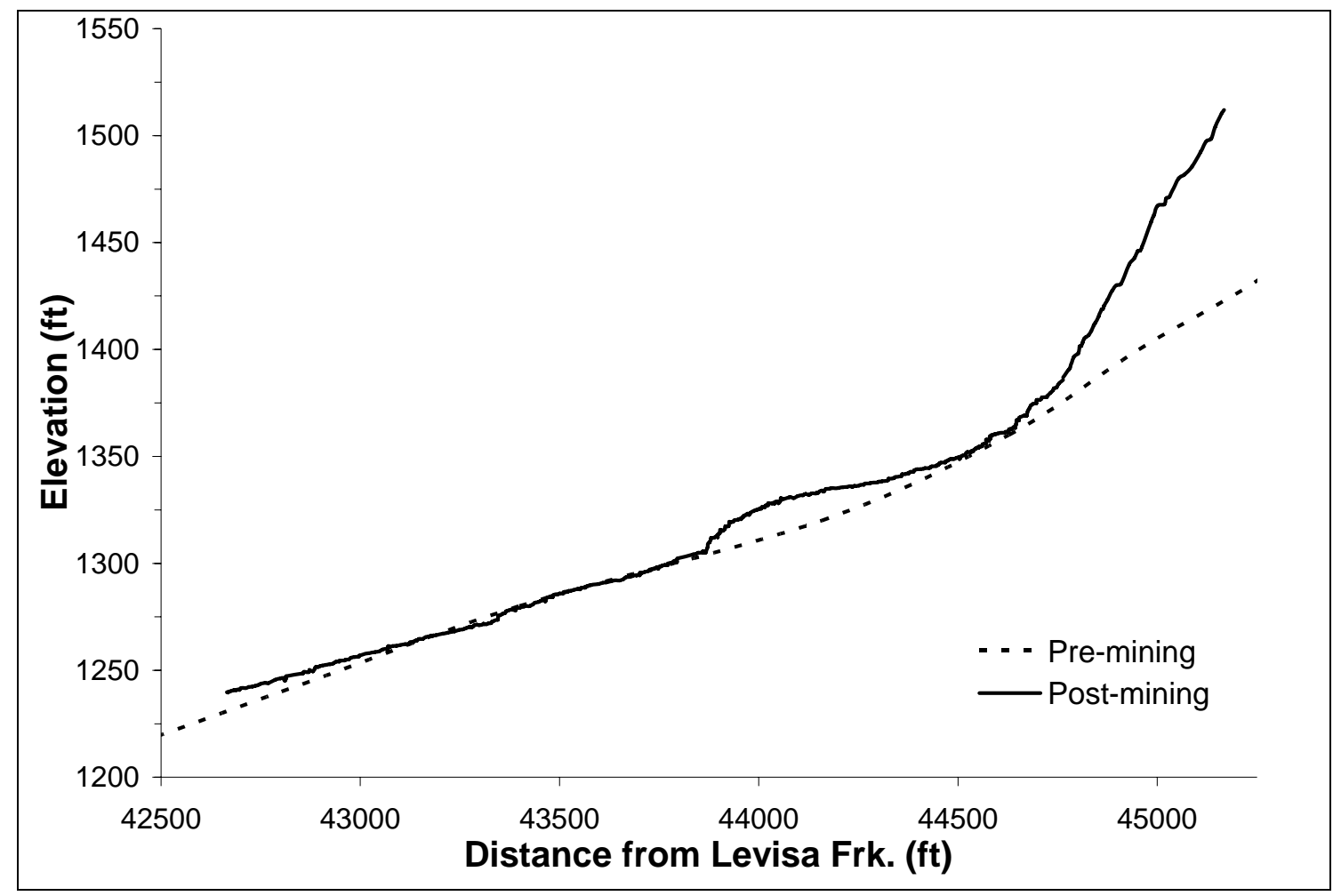

FIGURE 32 - Extent of Post-Mining Longitudinal Stream Survey for HF 10

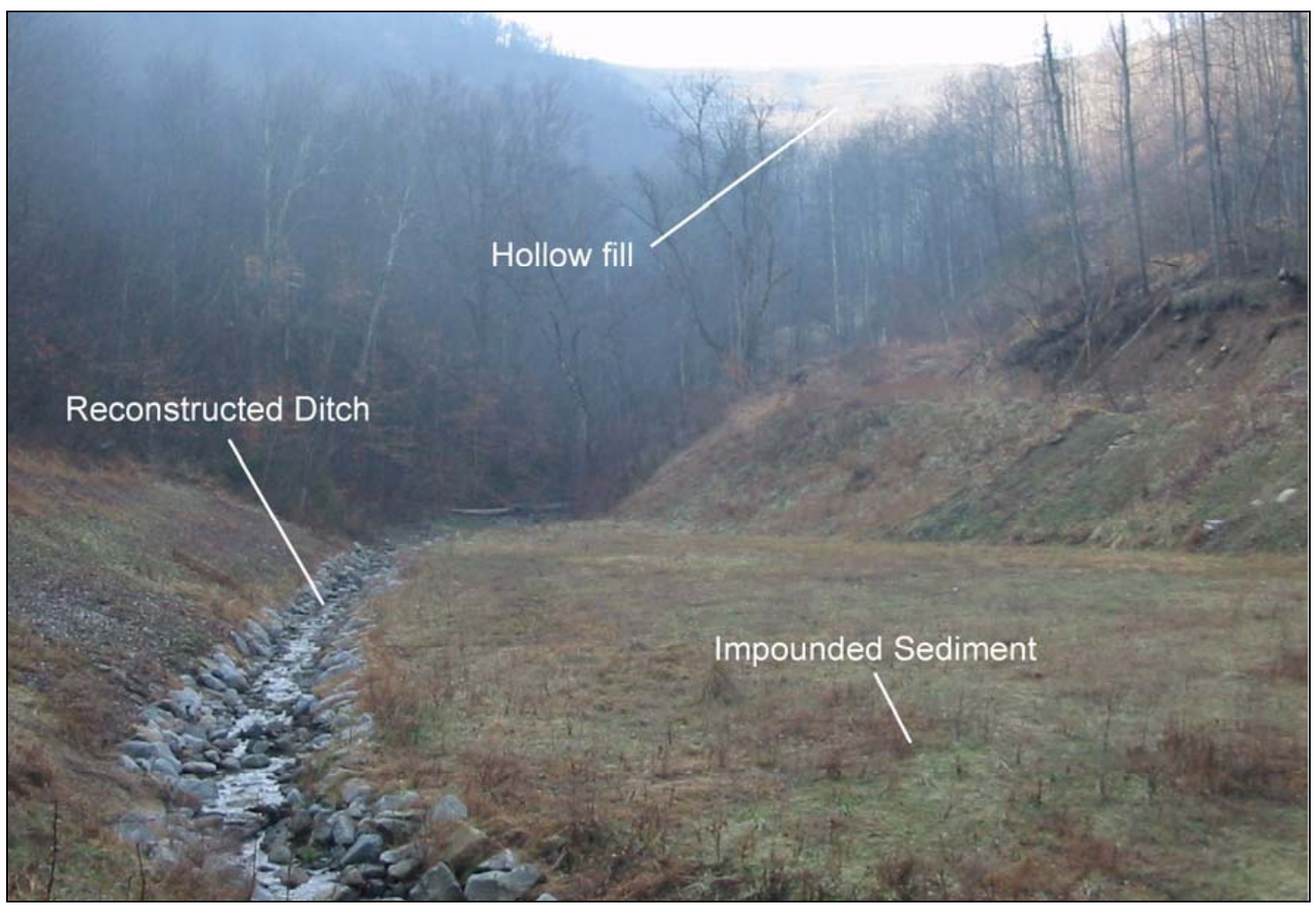

FIGURE 33 - Reclaimed Sediment Pond Area (HF 11) 
Stream channel morphology not directly modified by fill, check dam, or sediment pond construction was observed downstream of sediment ponds as well as upstream to the downstream-most rock check dam. Fluvial organization of the bed appeared limited due to relatively large clasts of colluvium. However, evidence of alluvial deposition was observed, as can be seen in Figure 34. Forced deposition was also observed behind flowobstructing objects such as the log shown in Figure 34b.

Hydrologic observations of the current study were related to stream flow regime. Effluent baseflow was observed at the toe of all fills visited despite the lack of recent rainfall, time of year (early August), and relatively small drainage areas (25.3-77.4 acres). Although not extensively investigated, the latter of these factors was inferred through a comparison of observed streamflow to drainage area. Specifically, HF 1 and HF 2 were associated with 42.2- and 45.3-acre drainage areas and both yielded streamflow. However, surface flow was not observed in a nearby, unfilled tributary stream with a drainage area of 63.2 acres. These findings possibly corroborate those of recent study by the U.S. Geological Survey (USGS) in cooperation with the West Virginia Department of Environmental Protection (WVDEP) (Wiley et al., 2001), in which durations of both base flow and low flow were found to be generally greater for streams below hollow fills than for streams in un-mined sites.

The thick, porous nature of the hollow fill deposit may create a condition favorable for the storage of groundwater and the consequent increase in base flow effluence noted by Wiley et al. (2001). This aquifer-like behavior may result in the displacement of regime transition zones. For example, if a fill is placed entirely within the ephemeral region of a headwater stream, the intermittent transition zone may be 
(a)

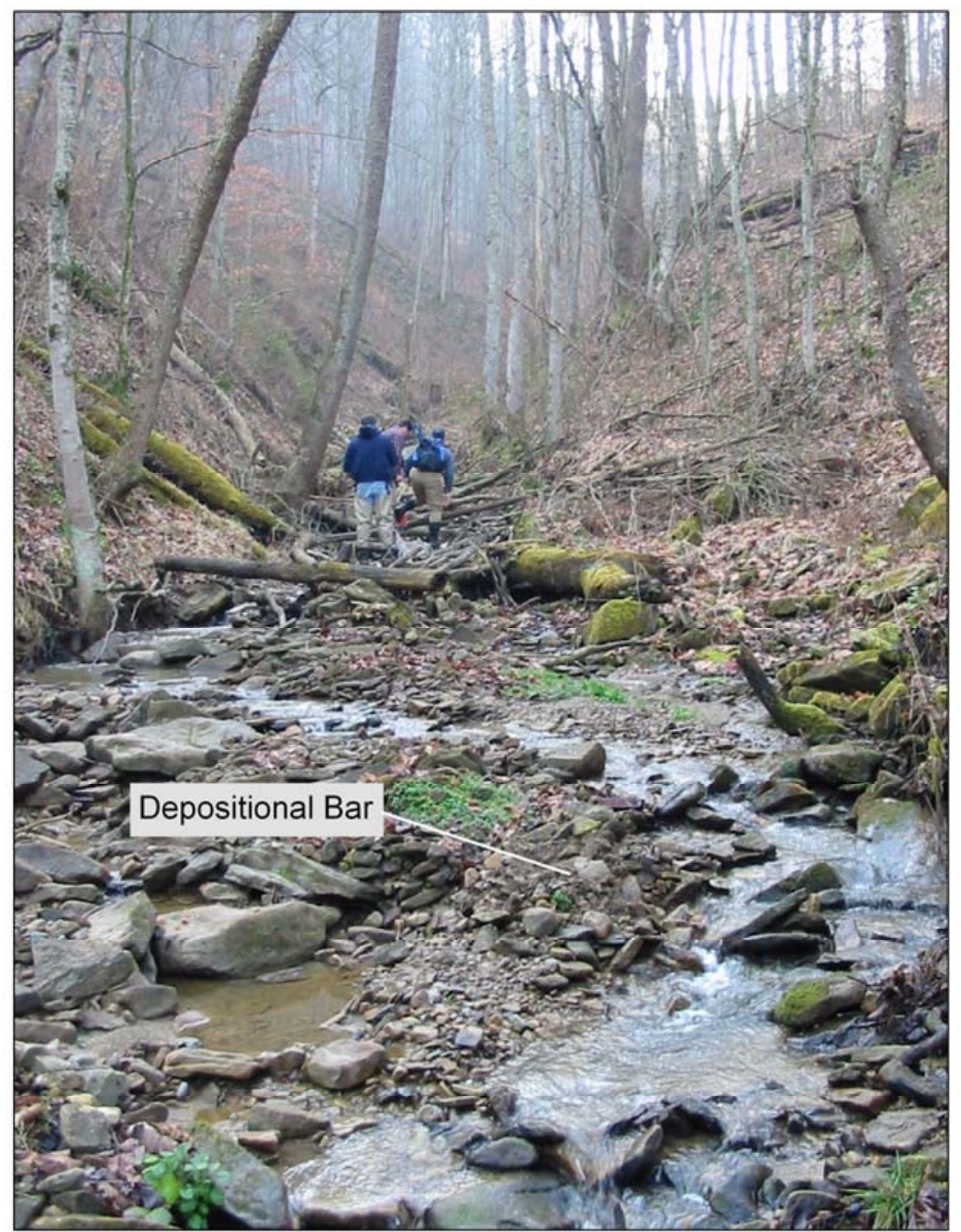

(b)

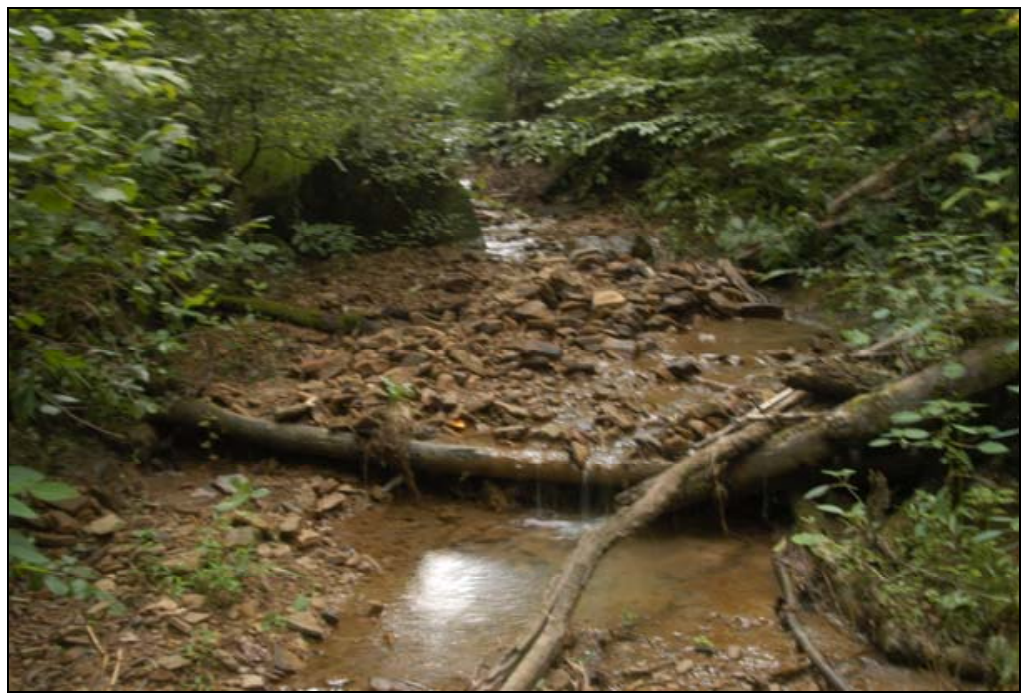

FIGURE 34 - Channel Morphology for Stream Reaches Adjacent to but Not Directly Altered by Constructed Structures; Evidence of (a) Fluvial Organization and (b) Forced Deposition of Sediment Downstream of HF 11 (a) and HF 4 (b) 
moved upstream to the base of the fill where stored water is being released. While increased baseflow and displacement of the flow regime transition zones are not geomorphic processes per se, they characterize an altered interaction between ground and surface water that should be of consideration to stream restoration efforts on and downstream of hollow fills.

\section{Geomorphic Processes}

Both fluvial and hillslope geomorphic processes were observed to be responsible for the characteristics of the landform evolution instigated by mining and hollow fill impacts. These processes warrant consideration during stream restoration planning due to the potentially detrimental short- or long-term impacts they may have on headwater stream ecology and fill stability. Direct changes to stream morphology as a result of groin ditch, rock check dam, or sediment pond construction may result in a stream with an altered sediment transport capacity. Depending on the altered channel substrate, hydrology, and other factors driving geomorphic processes, this new sediment transport capacity may instigate morphologic evolution different from that originally occurring in the pre-mining headwater stream. Further geomorphic implications may arise from altered sediment supply rates and load composition from natural hillsides or areas disturbed by mining processes and hollow fill construction. Observed fluvial geomorphic processes of importance are

1. Headcutting at former pond embankments

2. Headward propagation of morphologic instabilities

3. Headcutting near rock check dams

4. Sediment deposition at head of pond areas

5. Bank instability/incision downstream of fills

6. Bank instability along groin ditches 
Notable observed hillslope geomorphic processes include

1. Mass movement of hillslope debris into groin ditches

2. Rill erosion on hillsides and backfilled slopes

3. Fill subsidence

4. Weathering of nondurable rock lining groin ditches

The observed fluvial geomorphic processes are primarily related to vertical stability of channel form. The process of headcutting within the altered stream reaches at reclaimed sediment pond embankments and rock check dams is indicative of bed erosion, or degradation. Headward propagation of this vertical instability resulted in the observed stream incision and subsequent lateral bank instability of groin ditches and downstream channels alike. Also indicating vertical instability was the deposition of sediment observed at the low-gradient region of the reclaimed sediment pond area. This process signified channel aggradation, or elevation of the stream bed.

Hillslope processes observed adjacent to groin ditch and stream channels are governed by structural slope stability, surface flow erosivity, and erodibility of both natural hillside material and mining spoil of backfills and hollow fills. On hillslopes adjacent to hollow fills, these processes may be occurring naturally or as a result of certain mining-related disturbances to their governing factors. Erosion or subsidence of the hollow fill itself is a function of the constituent material and geometric fill configuration.

While delineated spatially, observed hillslope and channel processes retain the interdependency characteristic of the pre-mining condition. As an example, vertical stability of groin ditches of downstream impacted reaches directly affects hillslope baselevels and, therefore, the dependent magnitude and frequency of mass movement events. 
In turn, mass movements of hillslope material may alter channel morphology through the introduction of sediment.

a. Fluvial Processes. Observed fluvial processes related to vertical channel instability were found to correspond with facets of longitudinal stream profiles. Convexities in the streams' longitudinal profiles at the reclaimed sediment ponds are a result of the remnant embankment (dam) and the sediment wedge collected during the functional life of the pond. The convexity at rock check dam locations may result from a similarly collected sediment wedge acting as the base level for subsequently constructed groin ditches. In both locations, the profile of the stream (see Figures 35 and 36) would undergo a sudden drop from the upstream level of the collected sediment mass to the downstream level of the original channel bed. The abrupt breaks in the slope associated with these convexities may be referred to as knickpoints (Knighton, 1998; Leopold et al., 1992; Wohl, 2000).

Due to the sudden increase in channel slope, knickpoints may be areas of locally elevated average shear stress applied to the stream bed. This direct relation of shear stress to channel slope is demonstrated by Equation 1, with average boundary shear stress, $\tau_{b}$ $\left(\mathrm{lb} / \mathrm{ft}^{2}\right)$, serving as a close approximation to average bed shear stress and friction slope, $S_{f}$ (ft/ft), largely a function of channel slope (Chow, 1959; Henderson, 1966):

$$
\tau_{b}=\gamma R_{h} S_{f}
$$

In Equation $1, R_{h}$ is the hydraulic radius ( $\mathrm{ft}$ ) and $\gamma$ is the unit weight of water $\left(\mathrm{lb} / \mathrm{ft}^{3}\right)$.

The increased average bed shear stress at the former pond embankment and rock check dam drop greatly enhances the potential of the stream to entrain and transport 


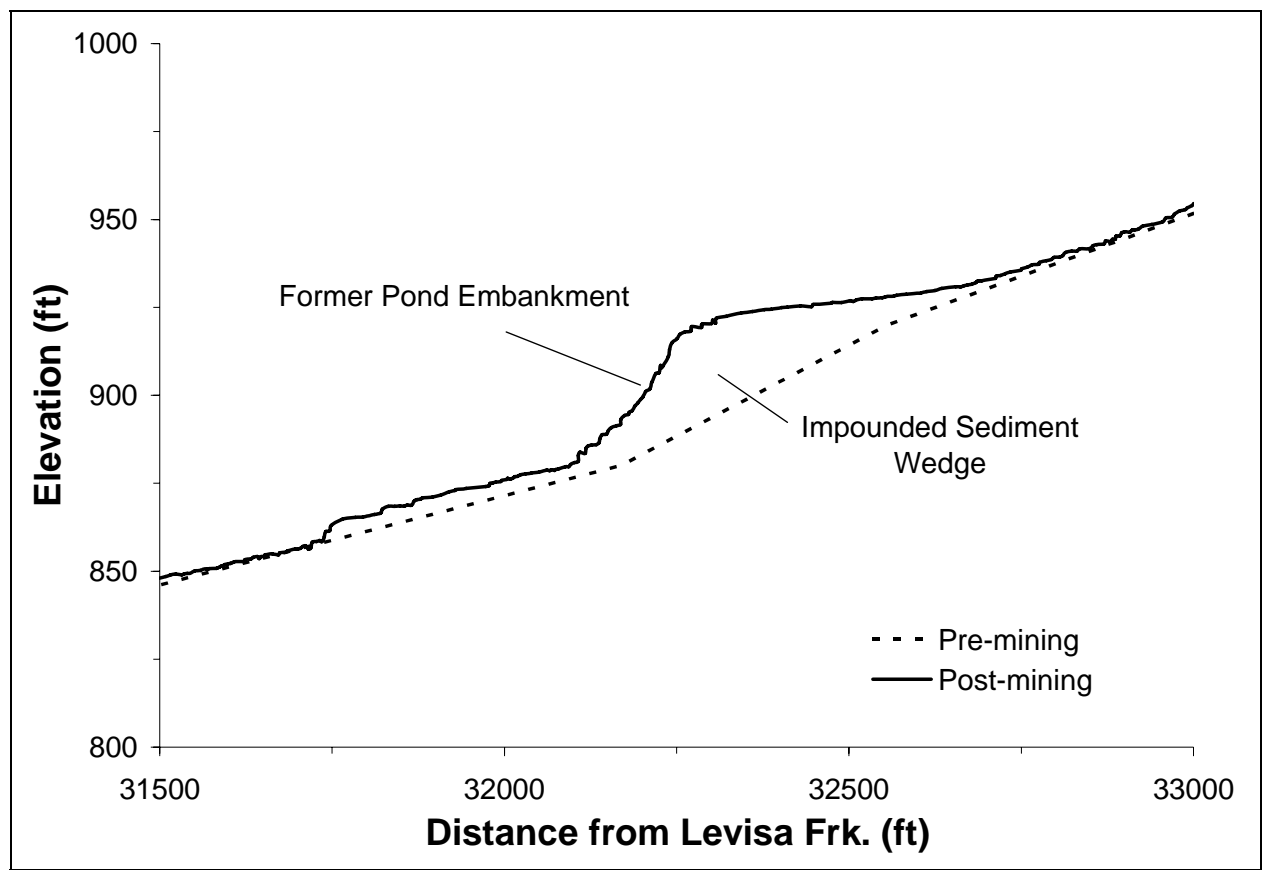

FIGURE 35 - Surveyed Longitudinal Stream Profile Revealing Knickpoint Created by Former Sediment Pond Embankment and Impounded Wedge of Sediment (HF 11)

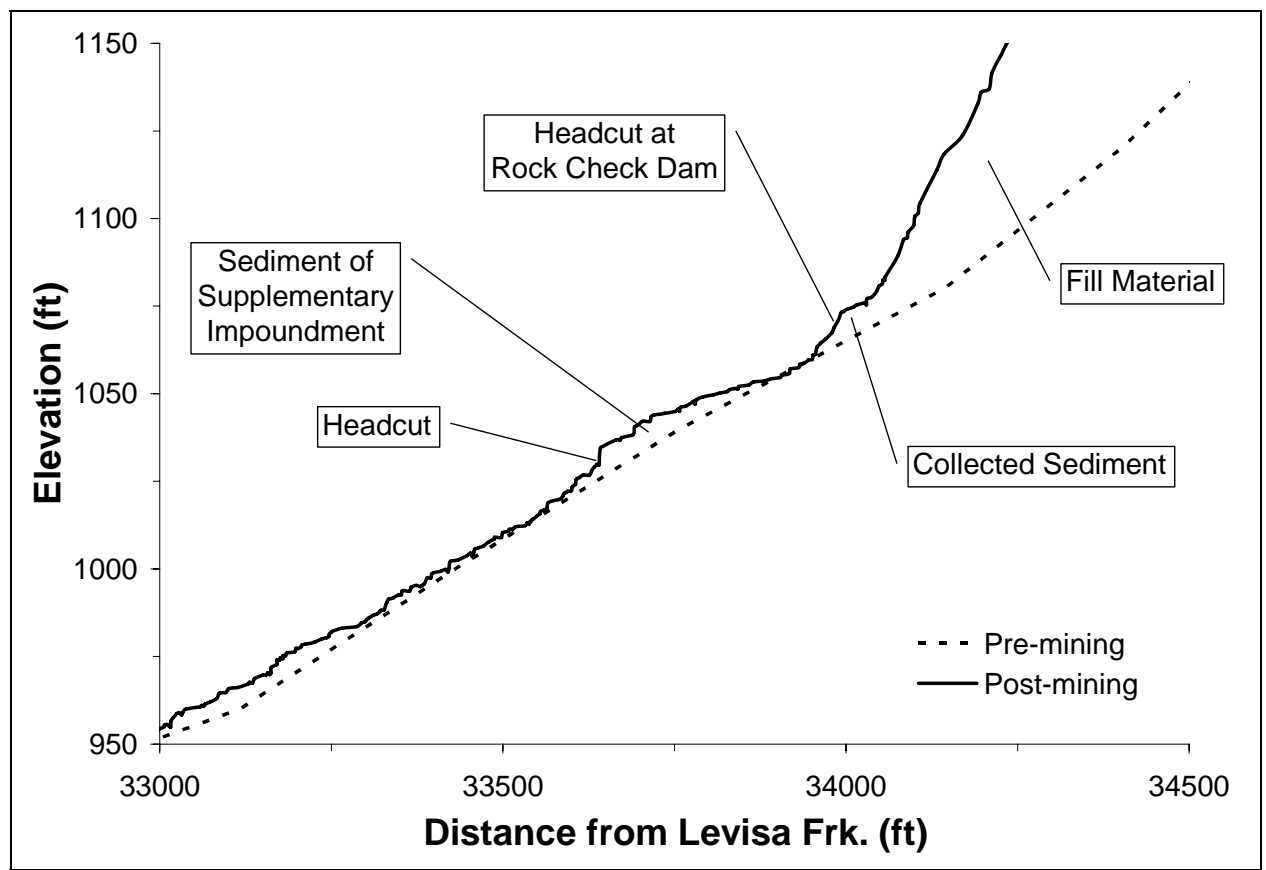

FIGURE 36 - Surveyed Longitudinal Stream Profile Revealing Knickpoints Created by a Supplementary Sediment Pond and Rock Check Dam (HF 11) 
material. This directly related potential can be seen in Equation 2, which relates the bedload sediment transport capacity per unit width in a dimensionless form, $q_{b}{ }^{*}$, to average bed shear stress also represented in a dimensionless form, $\tau^{*}$ (Parker, 2006):

$$
q_{b}^{*}=11.2\left(\tau^{*}\right)^{1.5}\left(1-\frac{\tau_{C}^{*}}{\tau^{*}}\right)^{4.5}, \tau_{C}^{*}=0.03
$$

$q_{b}{ }^{*}$ is more specifically referred to as the Einstein bedload number defined by

$$
q_{b}^{*}=\frac{q_{b}}{\sqrt{\operatorname{Rg} D} D}
$$

and $\tau^{*}$, known as Shields stress, is defined by

$$
\tau^{*}=\frac{\tau_{b e d}}{\rho \operatorname{Rg} D}
$$

The critical Shields stress, $\tau_{C}{ }^{*}$, required to initiate sediment movement is calibrated to be 0.03 under the assumption of fully turbulent flow and insignificant longitudinal slope (for knickpoints with significant longitudinal slope this value may be adjusted). In Equation 3, $q_{b}$ is the volumetric bedload sediment transport capacity per unit stream width $\left(\mathrm{ft}^{3} / \mathrm{s} / \mathrm{ft}\right), R$ is the specific gravity of the sediment, $g$ is the acceleration due to gravity $\left(\mathrm{ft} / \mathrm{s}^{2}\right), D$ is the representative sediment grain size $(\mathrm{ft}), \tau_{\text {bed }}$ is the average bed shear stress (approximately equivalent to $\tau_{b}$ in Equation 1 ), and $\rho$ is the density of water (slugs $/ \mathrm{ft}^{3}$ ).

The above equations indicate that increasing average shear stress may lead to increased sediment transport capacity; however, the nature of bed material also plays a role. While capacity to transport sediment may be increased along the high gradient reaches of the knickpoints, realization of an increased actual rate requires the presence of 
mobile sediment. The combination of a high sediment transport capacity and mobile sediment may cause the stream to incise through vertical degradation of the bed. The sediment transport equation presented here applies to fully turbulent flow in gravel-bed streams. This may not strictly be the case for stream reaches of the present study, but the basic concept of the positive correlation between shear stress and sediment transport applies nonetheless.

During the incision process initiated by locally high shear stresses, the knickpoint may migrate upstream in the form of a headcut, as described by Leopold et al. (1992). At reclaimed sediment ponds, headcutting may be a constituent mechanism of channel evolution similar to that occurring after the removal of a small dam as presented by Doyle et al. (2003): the channel evolves through a sequence of degradation, degradation and widening, aggradation and widening, and finally, quasi-equilibrium (Figure 37).

The physical appearance of a headcut may take on various forms ranging from abrupt drops in the channel bed (Figure 38) to less pronounced erosional faces, depending on the material through which the stream is incising (Leopold et al., 1992; Wohl, 2000). With the exception of a sediment pond below HF 4 and HF 9 (Figure 38a), large rip-rap was used at the observed embankments to armor this high gradient reach and thus protect the underlying finer-grained, mobile material from erosion (Figure 39). At all sites, large boulders were used to construct rock check dams. While the large rocks lining sediment pond channels and composing rock check dams may be relatively immobile, erosion of underlying material may occur, resulting in headcut initiation. Channel morphology left in the wake of a migrating headcut may be characterized by lowered bed elevations and subsequently larger bank heights and steeper bank angles. This new, incised geometry 
(a)
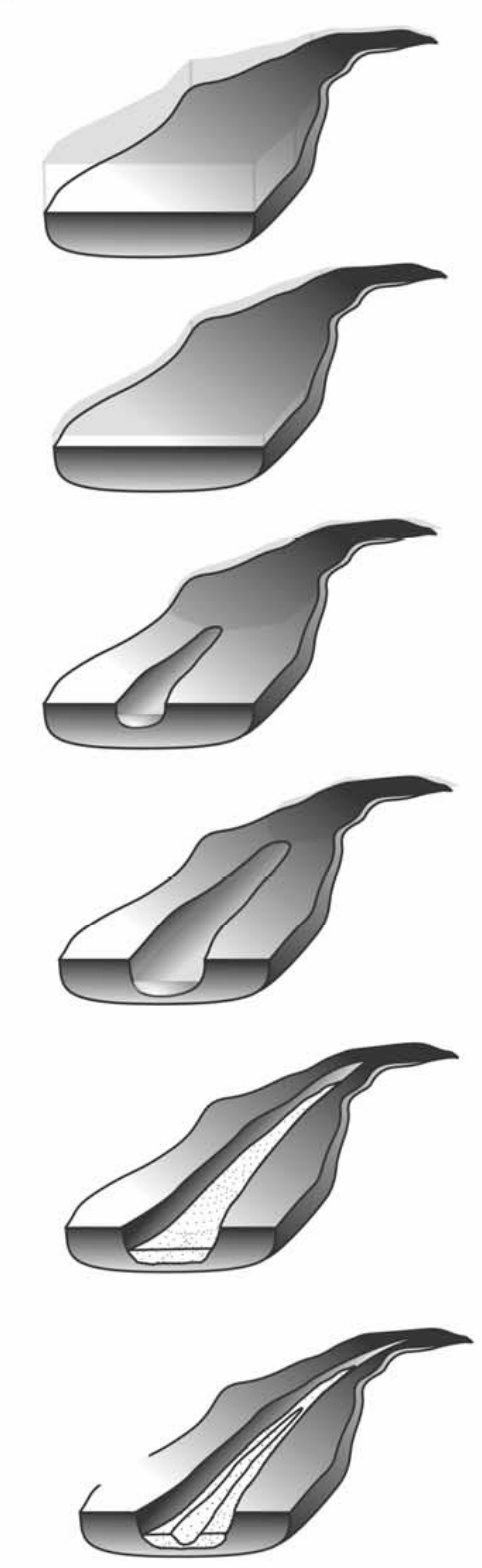

(b)

STAGE A

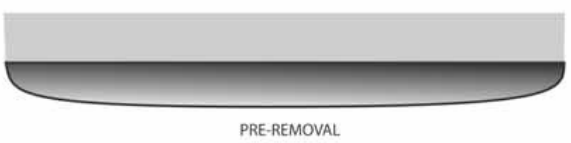

PRE-REMOVAL,

STAGE B

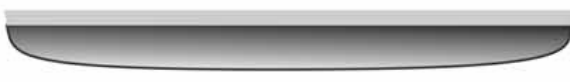

LOWERED WATER SURFACE

STAGE C

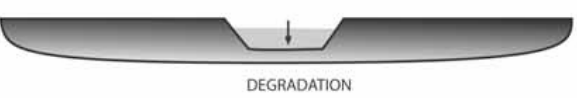

STAGE D

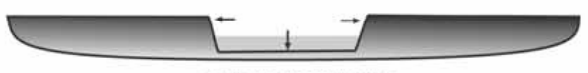

DEGRADATION \& WIDENING

STAGE E

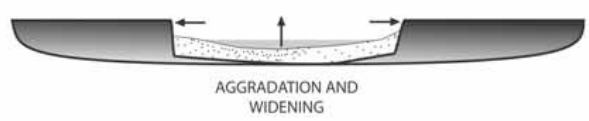

STAGE F

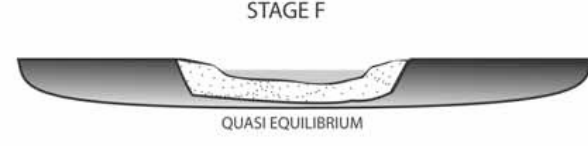

(c)

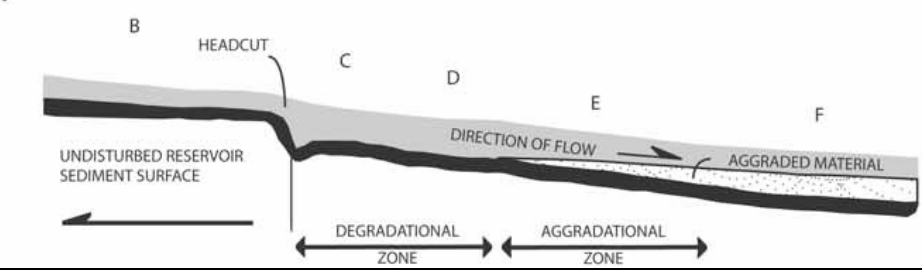

FIGURE 37 - (a) 3-Dimensional, (b) Cross-Sectional, and (c) Longitudinal Views of Typical Channel Evolution after the Removal of a Small Dam (Doyle et al., 2003); Stages C or D are Similar to Observations at Reclaimed Sediment Ponds 
(a)

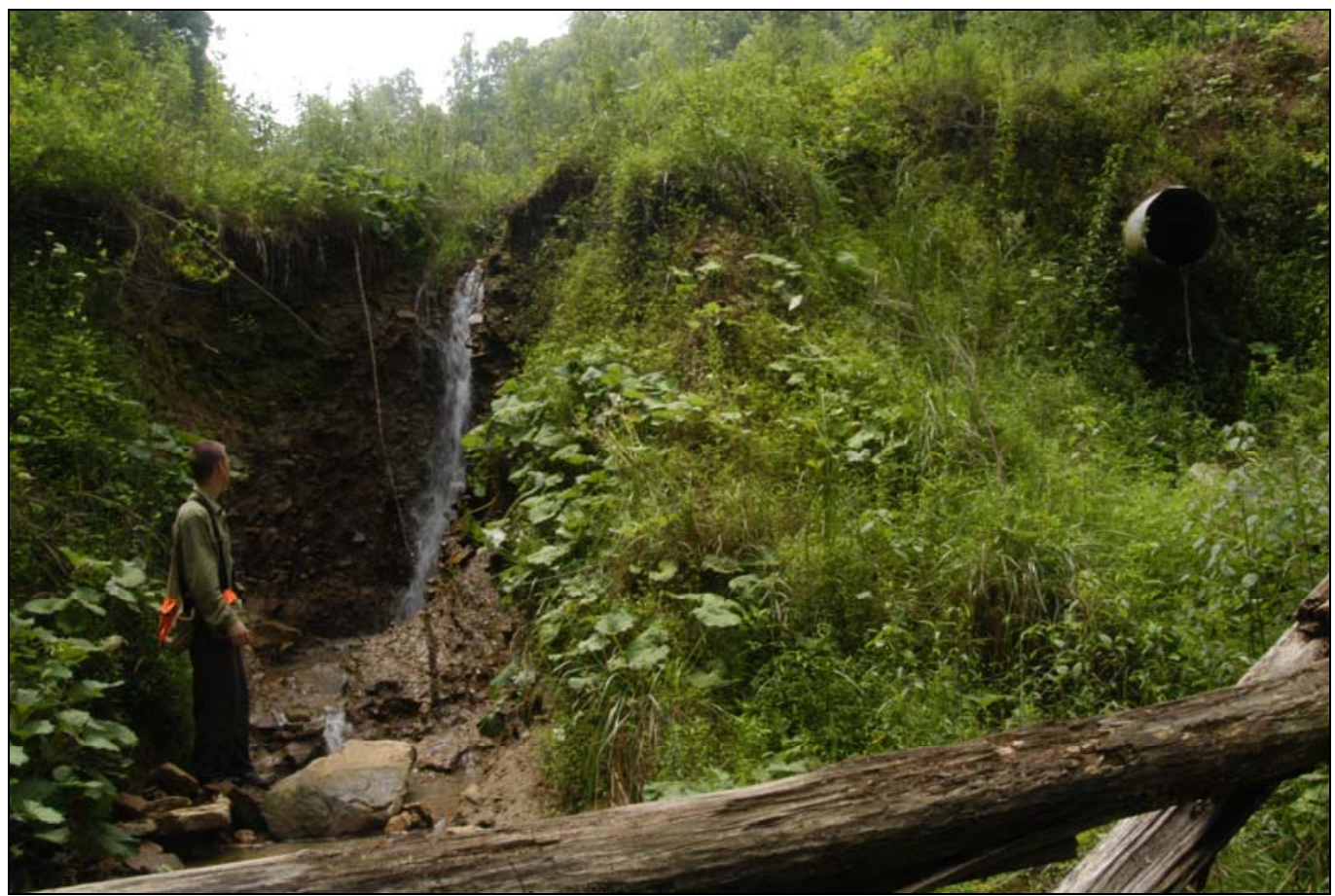

(b)

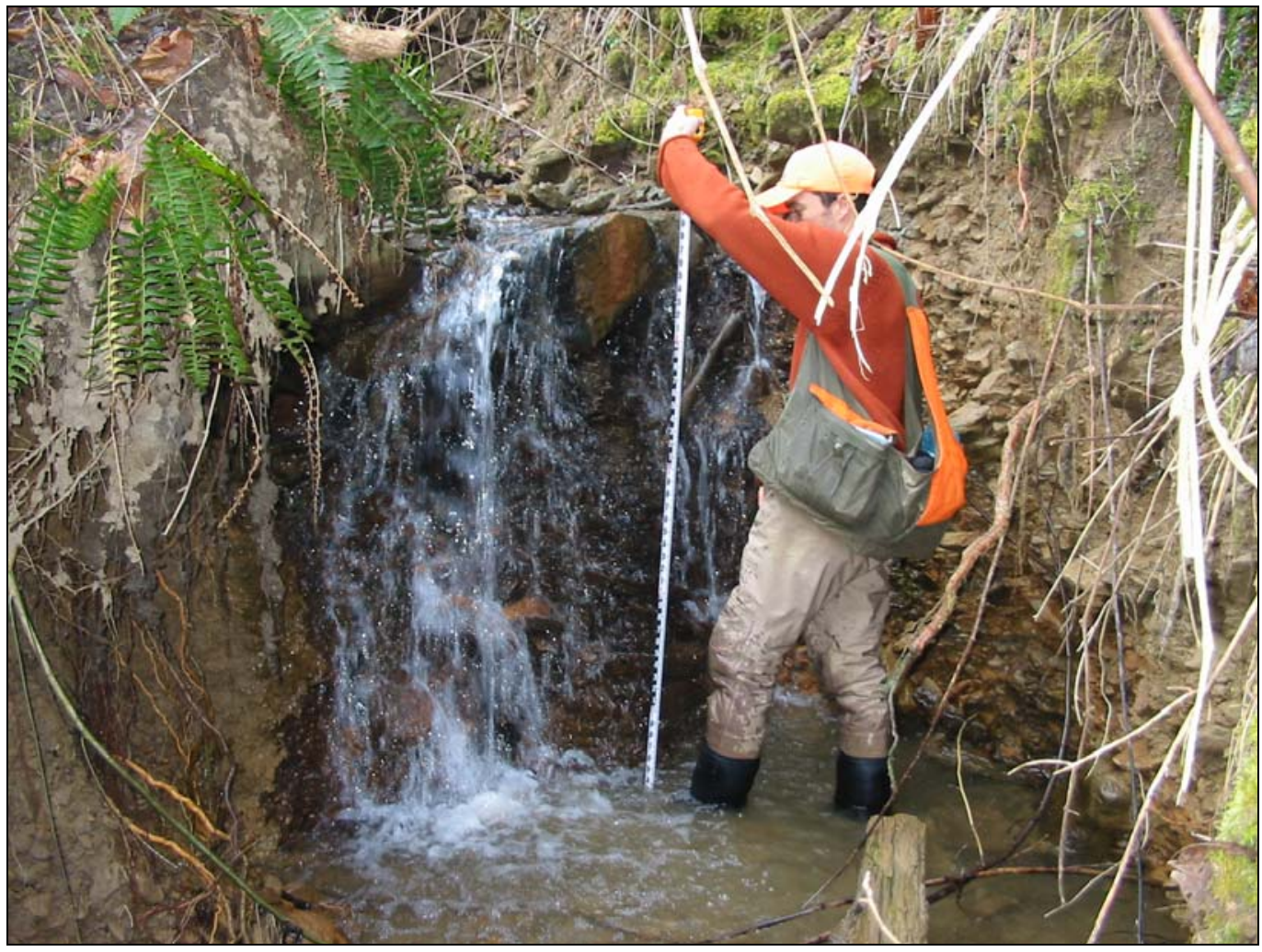

FIGURE 38 - (a) A Dramatic Example of a Vertical Headcut at Sediment Pond Downstream of HF 4 and HF 9: Headcut Represented by an Approximately 10-foot Vertical Face;

(b) Vertical Face of Headcut in Material of Supplementary Sediment Pond (HF 11) 
(a)

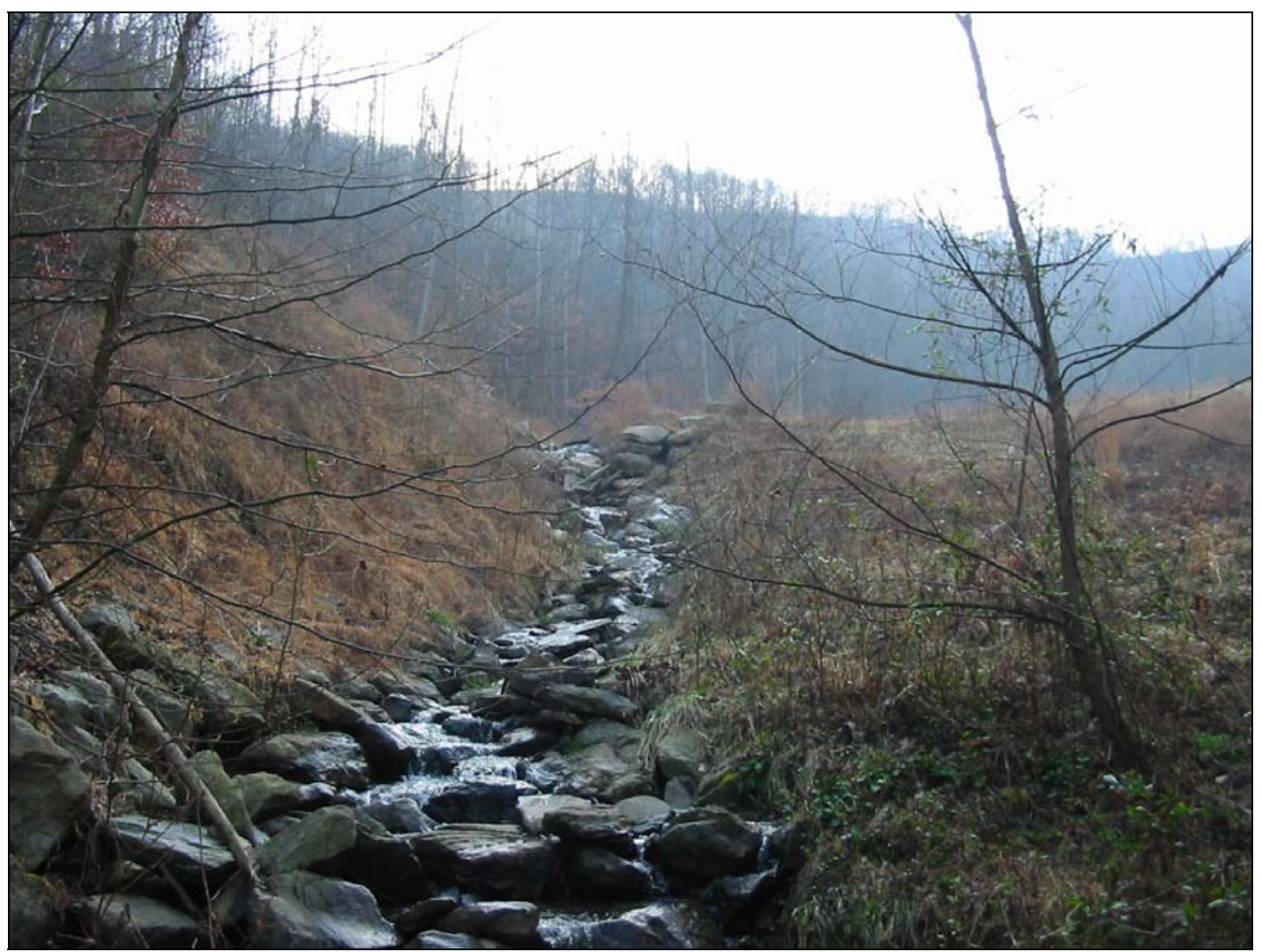

(b)

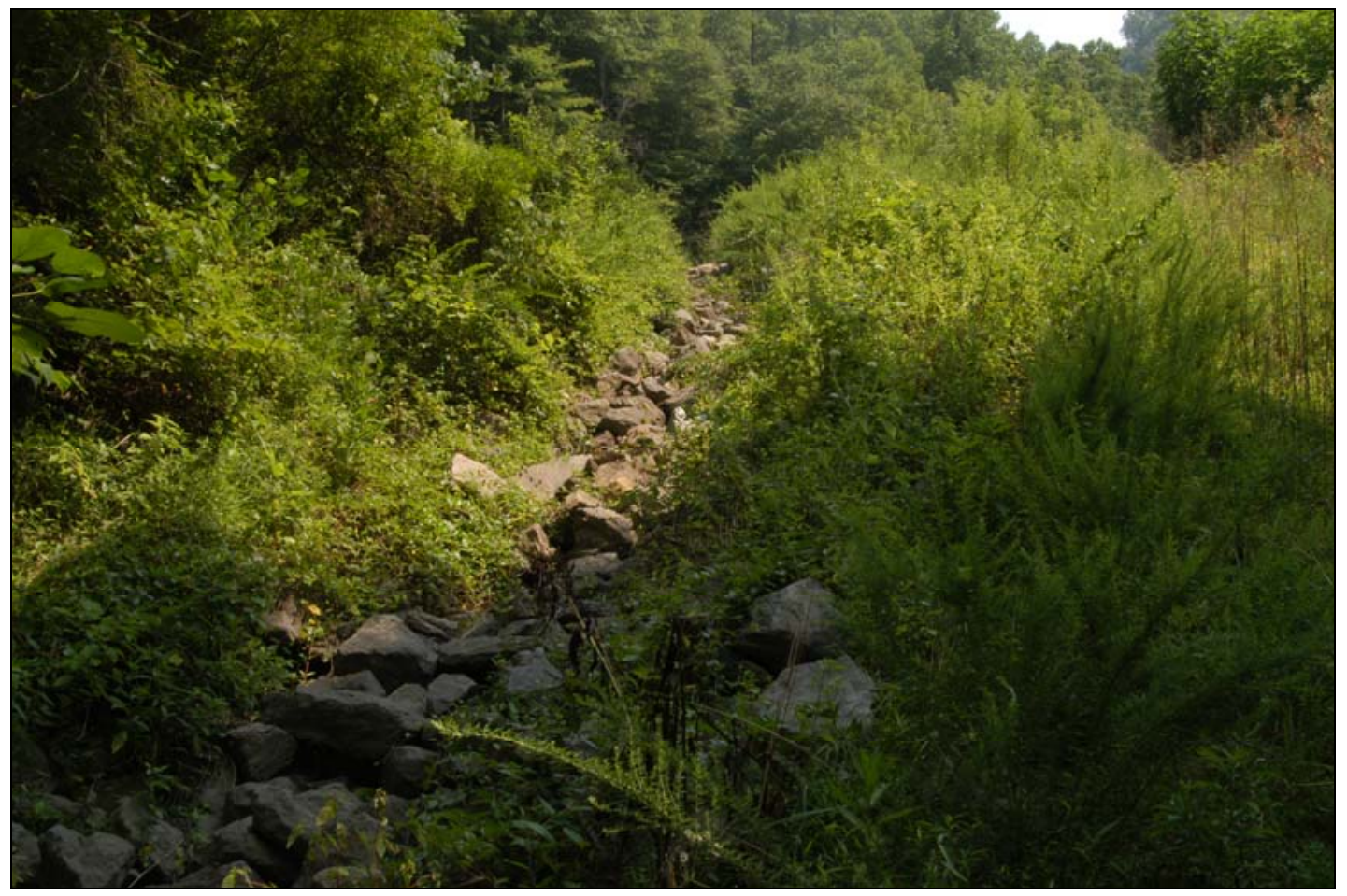

FIGURE 39 - Reconstructed Channels on Sediment Pond Embankments Downstream of (a) HF 11 and (b) HF 2 
may create a condition of geotechnical bank instability in which the shear strength of bank material is overcome. Mass wasting by gravity of this material may result (Figure 40). Unstable banks flanking the rock structure of Figure 41 and bordering the stream of Figure 42 provide evidence of channel degradation after passage of a headcut. Similar bank instability was observed within groin ditches.

The upstream limit of headcut propagation may be a function of the crosssectional geometry of the incising stream. Lowering of the bed elevation during stream incision creates relatively higher banks that contain a flow formerly allowed to dissipate energy across a wider, shallower cross section (perhaps including a floodplain). Thus, for the same flood flow rate, the incising channel would have a greater flow depth (hydraulic

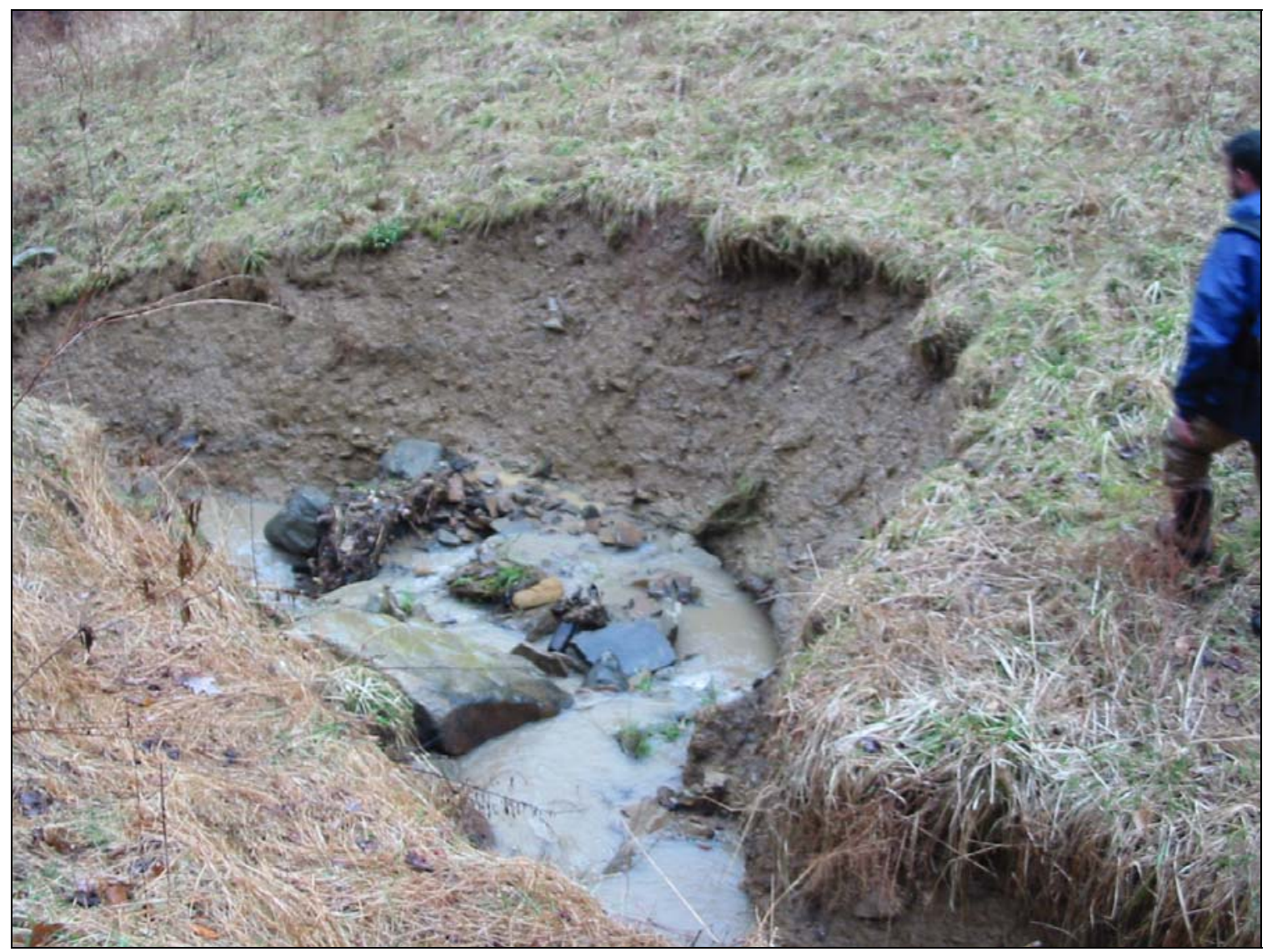

FIGURE 40 - Evidence of Mass Wasting and Bank Instability during Bed Degradation of Reconstructed Stream Reach Across Reclaimed Sediment Pond Area (HF 10) 
(a)

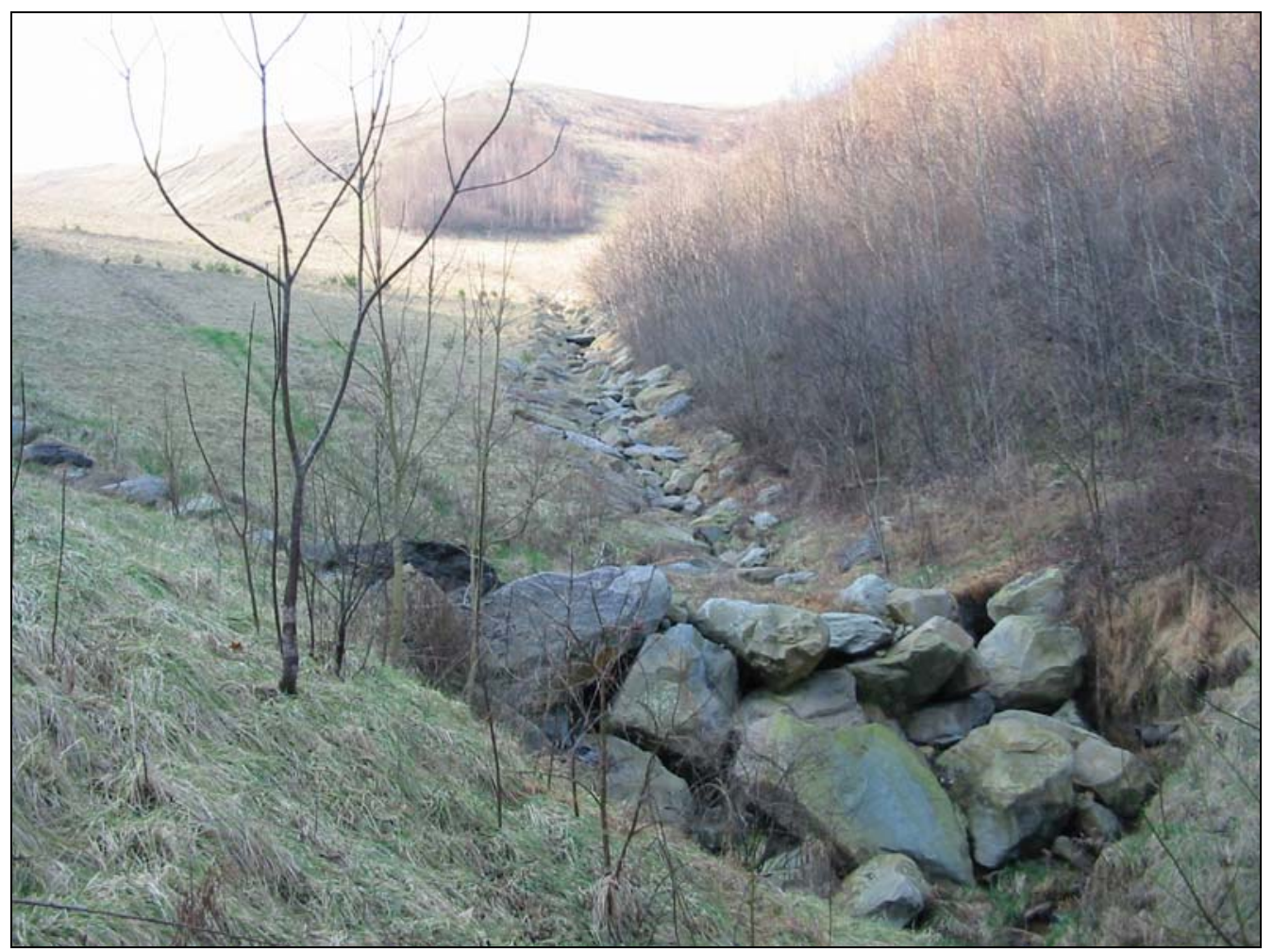

(b)

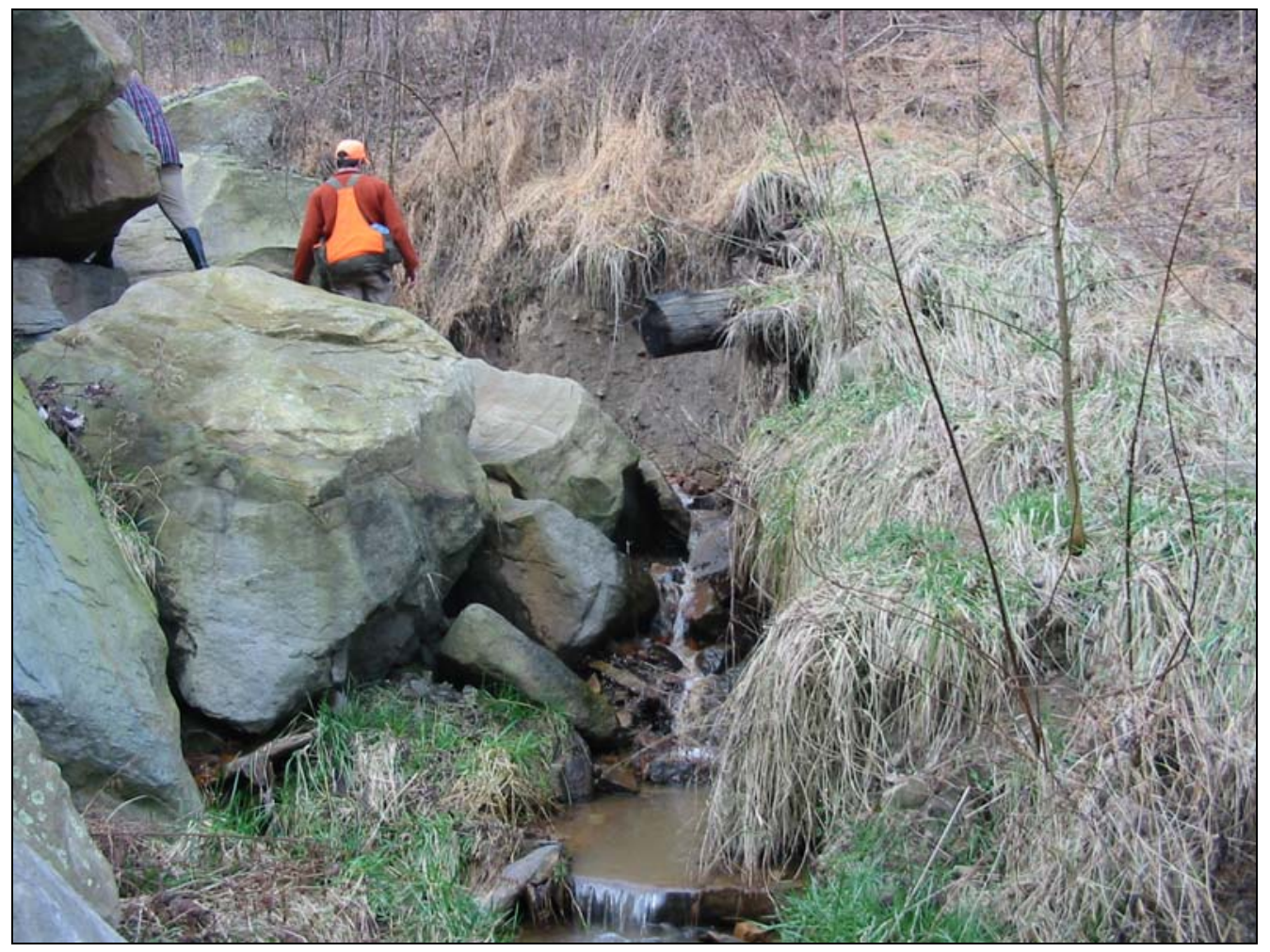

FIGURE 41 - High, Actively Eroding Bank Flanking Rock Check Dam Indicating Bed Degradation Possibly After the Initiation and Passage of a Headcut (HF 11); (a) Perspective View, (b) Close-up View 
(a)

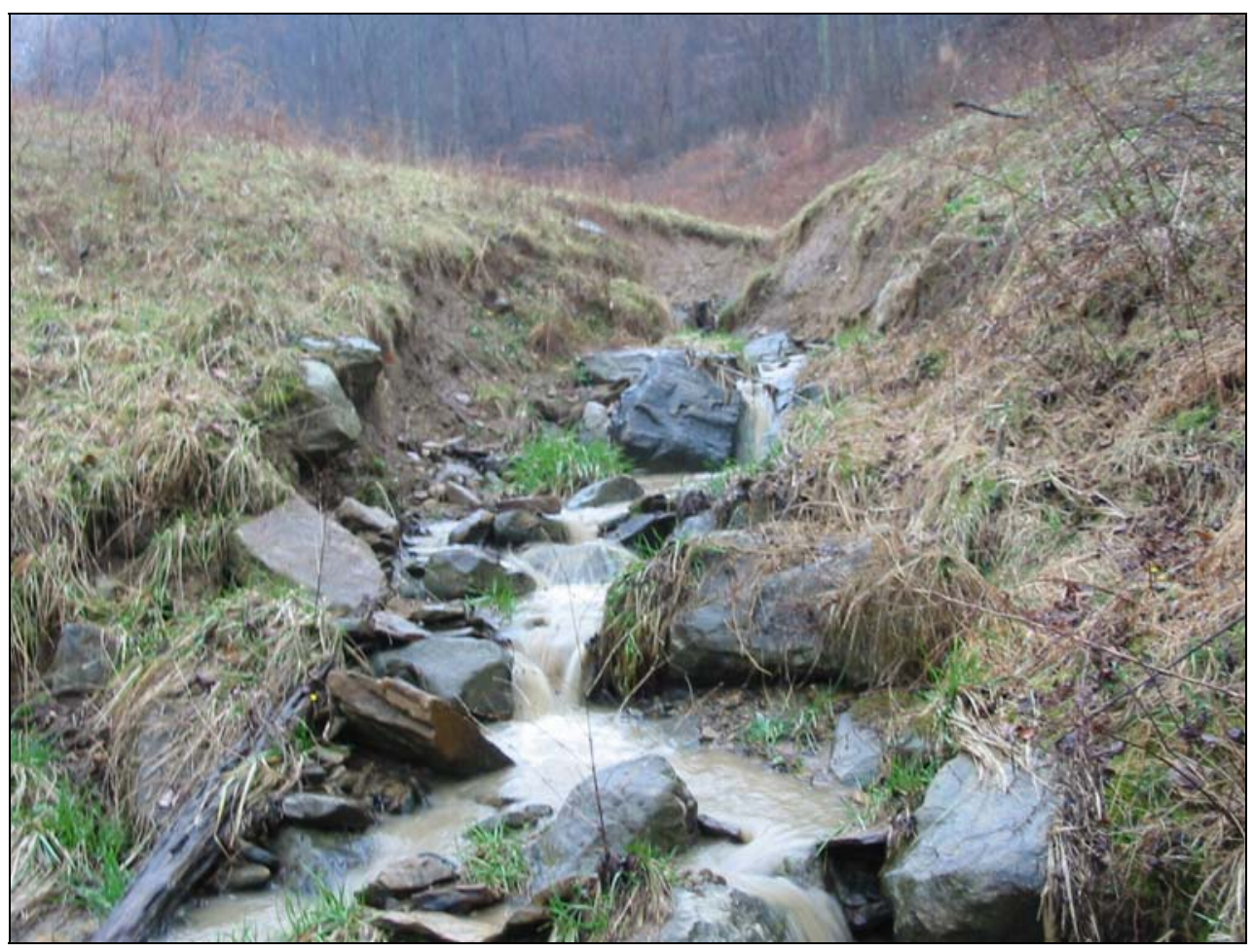

(b)

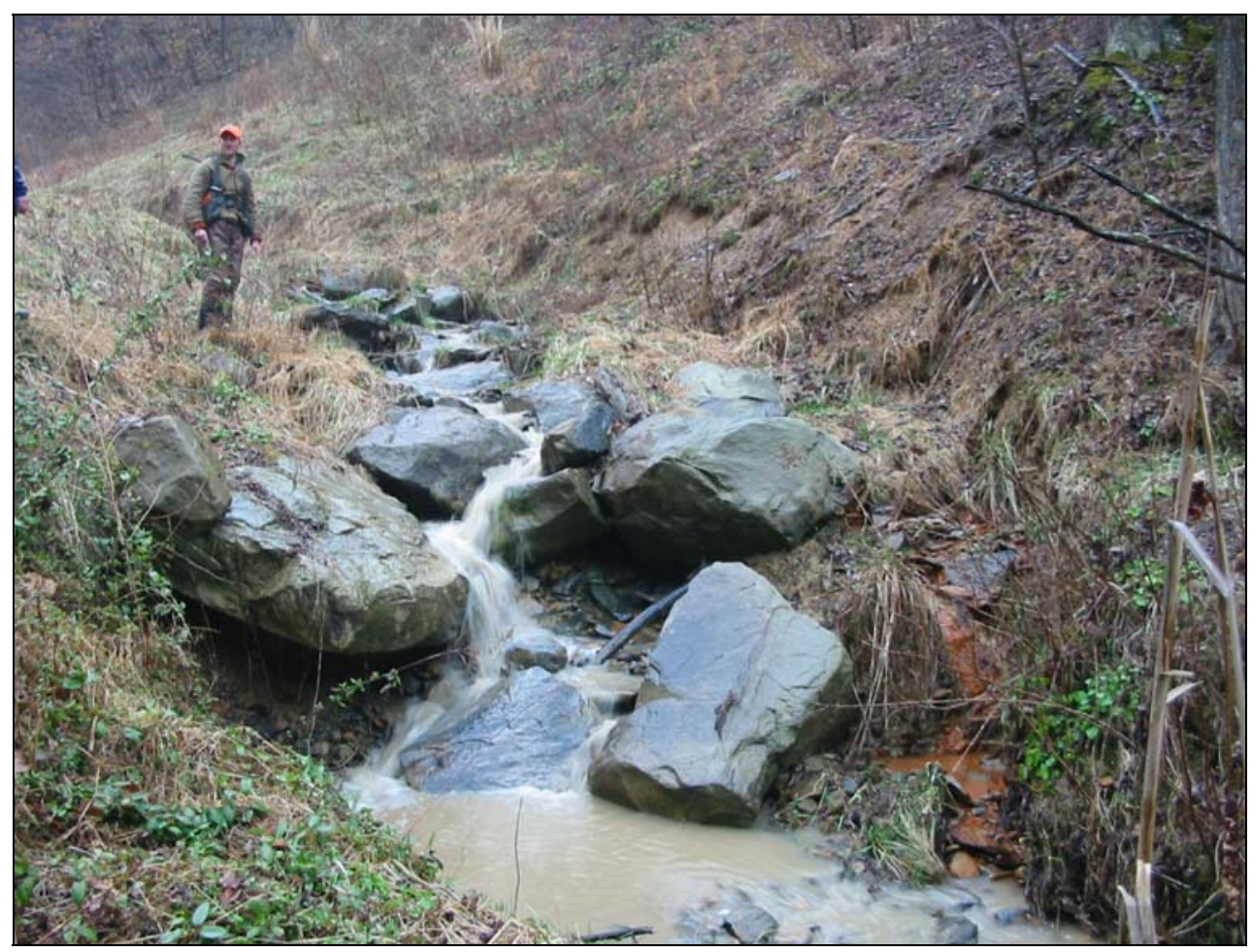

FIGURE 42 - Unstable Banks and Displaced Rip-Rap Indicating Failure of Large Rip-Rap Armoring to Prevent Bed Degradation at a Reconstructed Reach Across a Reclaimed Sediment Pond Area (HF 10) 
radius). Boundary shear stress, which is directly related to hydraulic radius, would correspondingly increase along with the stream's sediment transport capacity. A positive feedback loop would therefore be initiated, leading to the possibility of degradation beyond the original stream bed elevation. Implications of this advanced drop in bed level may include the headward progression of incision beyond the pond area. At rock check dams, headcuts may propagate upstream into groin ditches.

Even though the banks of groin ditches are also armored by large rip-rap, the underlying material may be similarly subjected to erosion. Field observations indicate that in some instances, rip-rap boulders failed to protect the finer-grained material of the fill or adjacent hillside from erosion and may have exacerbated the condition. During periods of runoff, flow may be concentrated within the interstices of the large boulders due to low submergence of the relatively large clasts and lack of void-filling intermediate particle sizes. Depending on the arrangement of the boulders, flow may be directed around or beneath these large rocks toward the potentially mobile material they were intended to protect. Evidence of the resulting undermining and side-mining was observed (Figure 43) and may co-exist with vertical degradation of the groin ditch channel resulting from headward-propagating instability.

Downstream from the eroding groin ditches, sediment deposition was observed at the head of reclaimed pond areas. Like the steep slope of the embankment, the lowgradient imposed by the impounded sediment wedge may induce geomorphic activity through alteration of the equilibrium sediment transport capacity. Vertical instability in the form of aggradation occurs in response to a decreased sediment transport capacity within this reach of decreased slope. This condition may be exacerbated if the postmining cross-sectional geometry of the channel creates a condition of wider, shallower 
(a)

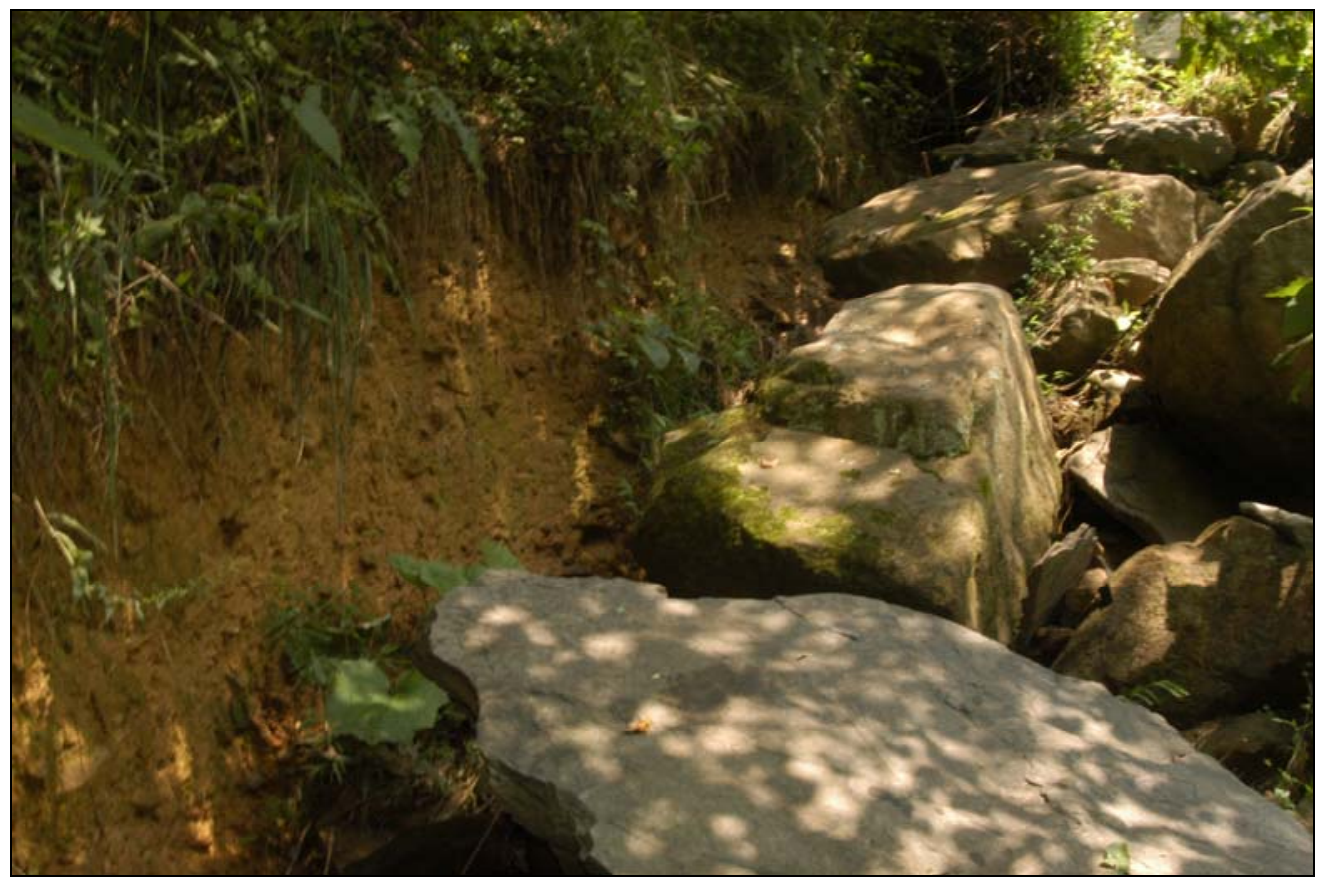

(b)

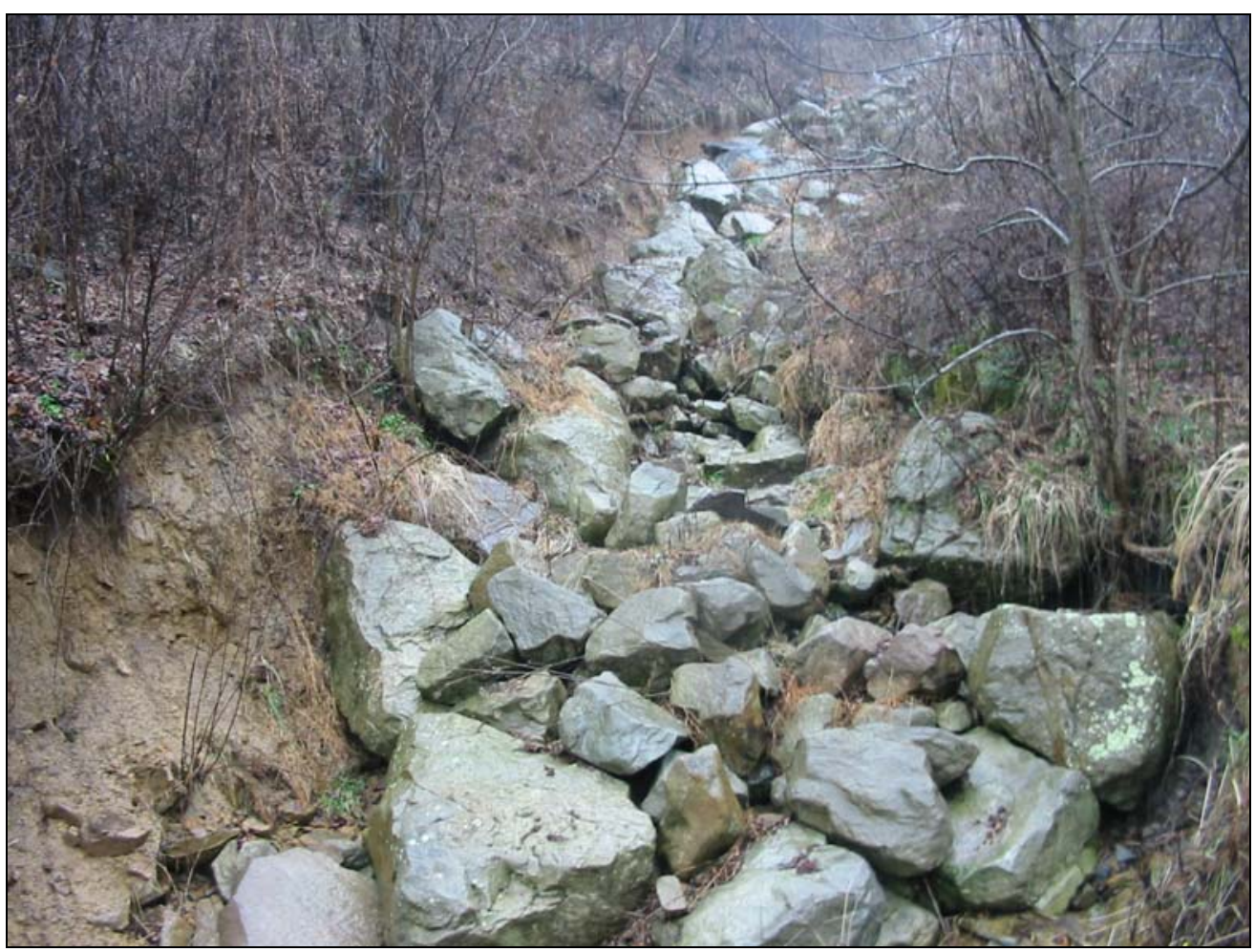

FIGURE 43 - Evidence of Undermining and Bank Instability Along Groin Ditches of (a) HF 2 and (b) HF 10 
flow. Sediment that would normally be conveyed by the former, steeper stream was observed to be deposited in a fan-like splay of silt, sand, and small gravel. At this location, stream morphology was evolving into small, meandering channels amongst large depositional features (Figure 44). Additionally, the riparian zone resembled a possibly emerging wetland (Figure 45).

b. Hillslope Processes. Erosional hillslope processes and fill subsidence were observed to be acting simultaneously with the fluvial processes of post-mining stream channels. Observed evidence of erosional processes took the form of episodic mass movement debris and rills on disturbed slopes. At select sites, the occurrence of fill subsidence was inferred through observed alterations to preferential surface water flow paths and discernable changes to hollow fill configuration.

The natural mass movement of material on hillslopes may continue to occur in the presence of hollow fill impacts. In some instances mining-related impacts may increase the frequency of such events through the removal of vegetation, increasing of slope loading, under-cutting of natural slopes, or alteration to surface or groundwater flow (USEPA, 2003). Evidence of mass movement by landsliding was observed on a natural hillslope adjacent to HF 11 (Figure 46).

The persistence of natural mass movement events such as episodic landsliding is accompanied by continued interaction of the hillslopes with the fluvial system in the form of sediment supply. Adjacent to hollow fills, episodic processes may play a significant role as a sediment source to groin ditches. The recent landslide shown in Figure 46 introduced a large volume of soil and rock to the base level groin ditch, as can be seen in Figure 47. 
(a)

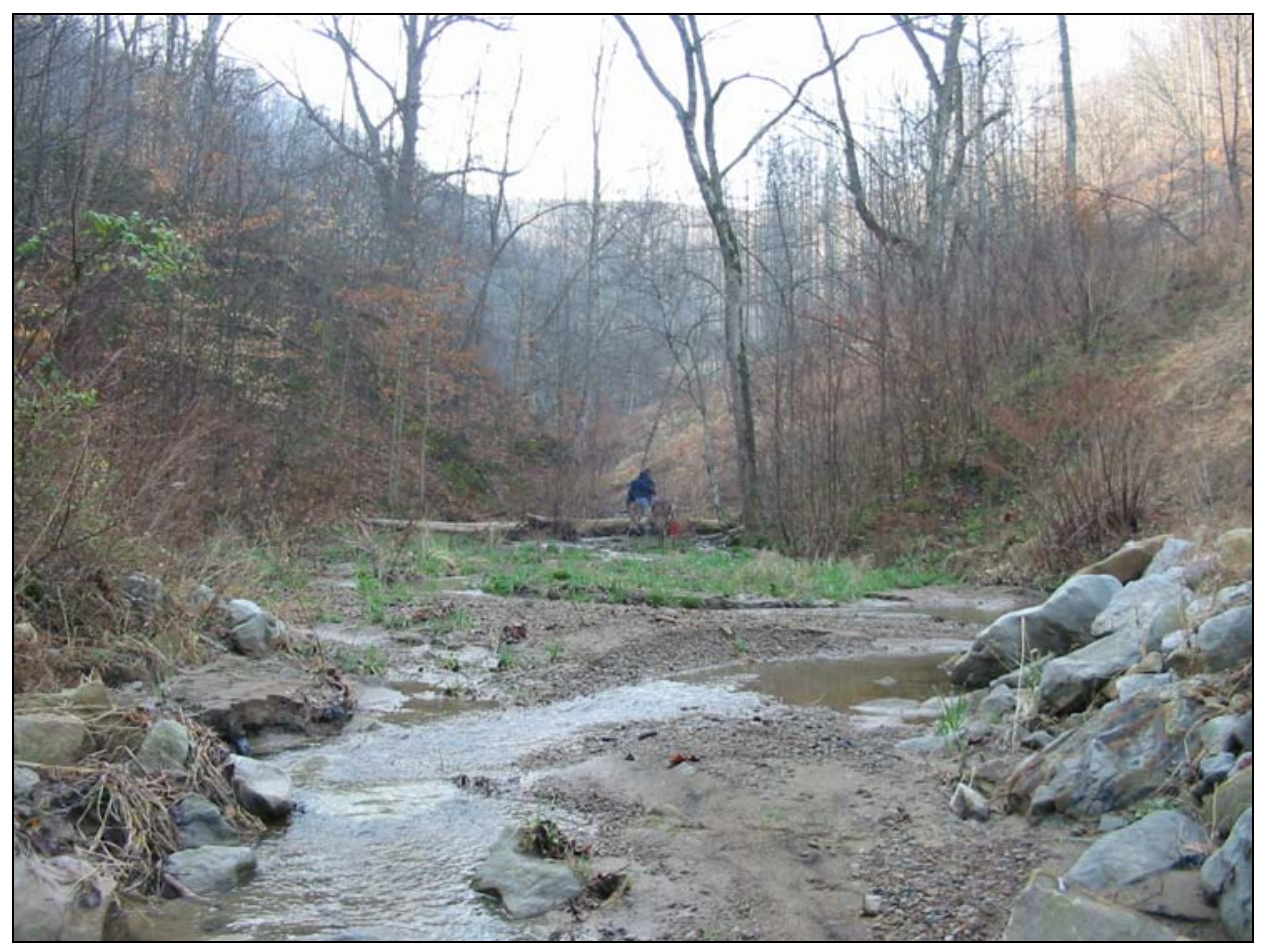

(b)

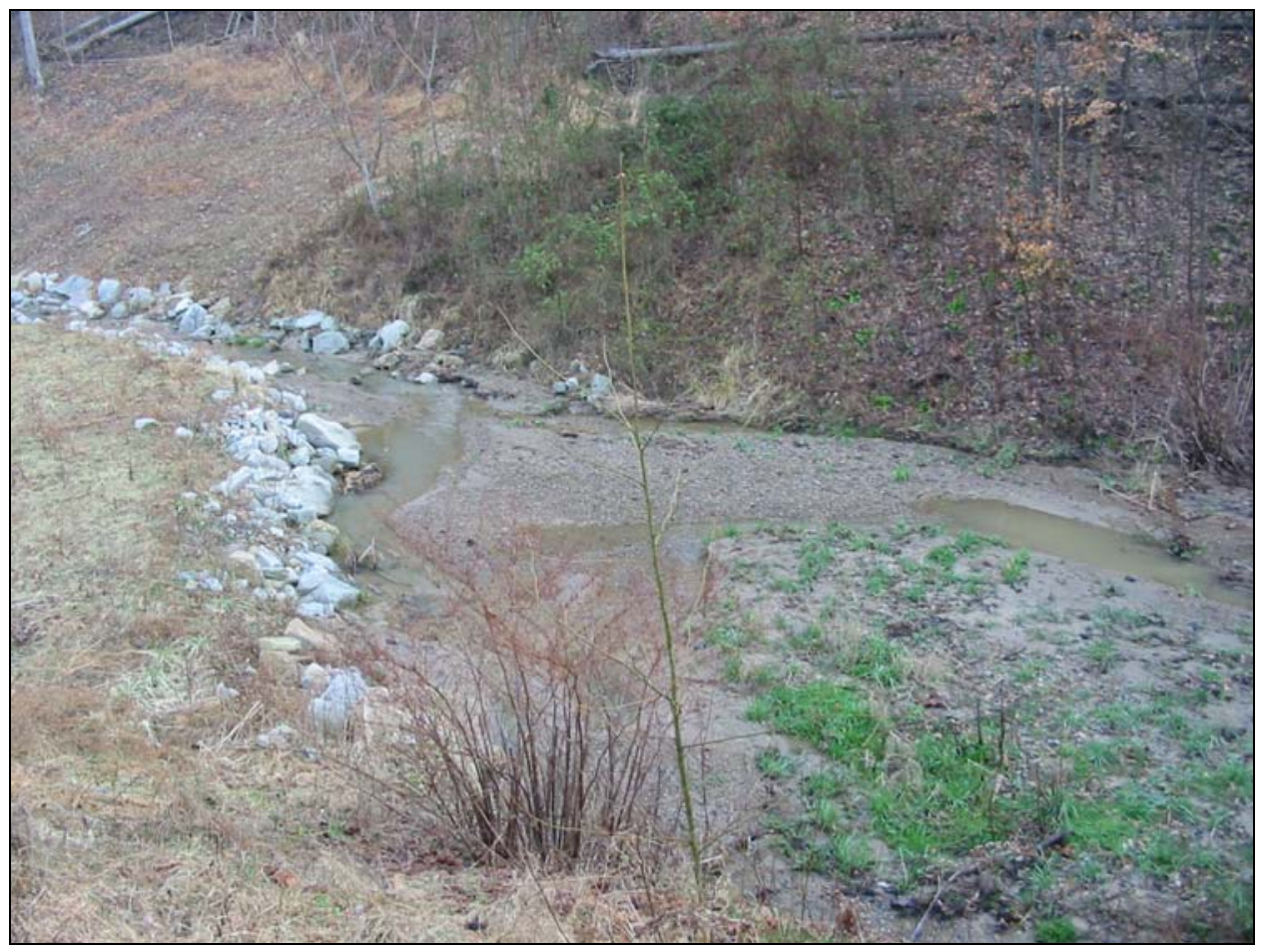

FIGURE 44 - Fine-Grained Sediment Deposit at Low-Gradient Reach of Reclaimed Sediment Pond Area Looking (a) Upstream and (b) Downstream from Head of Reconstructed Channel (HF 11) 
(a)

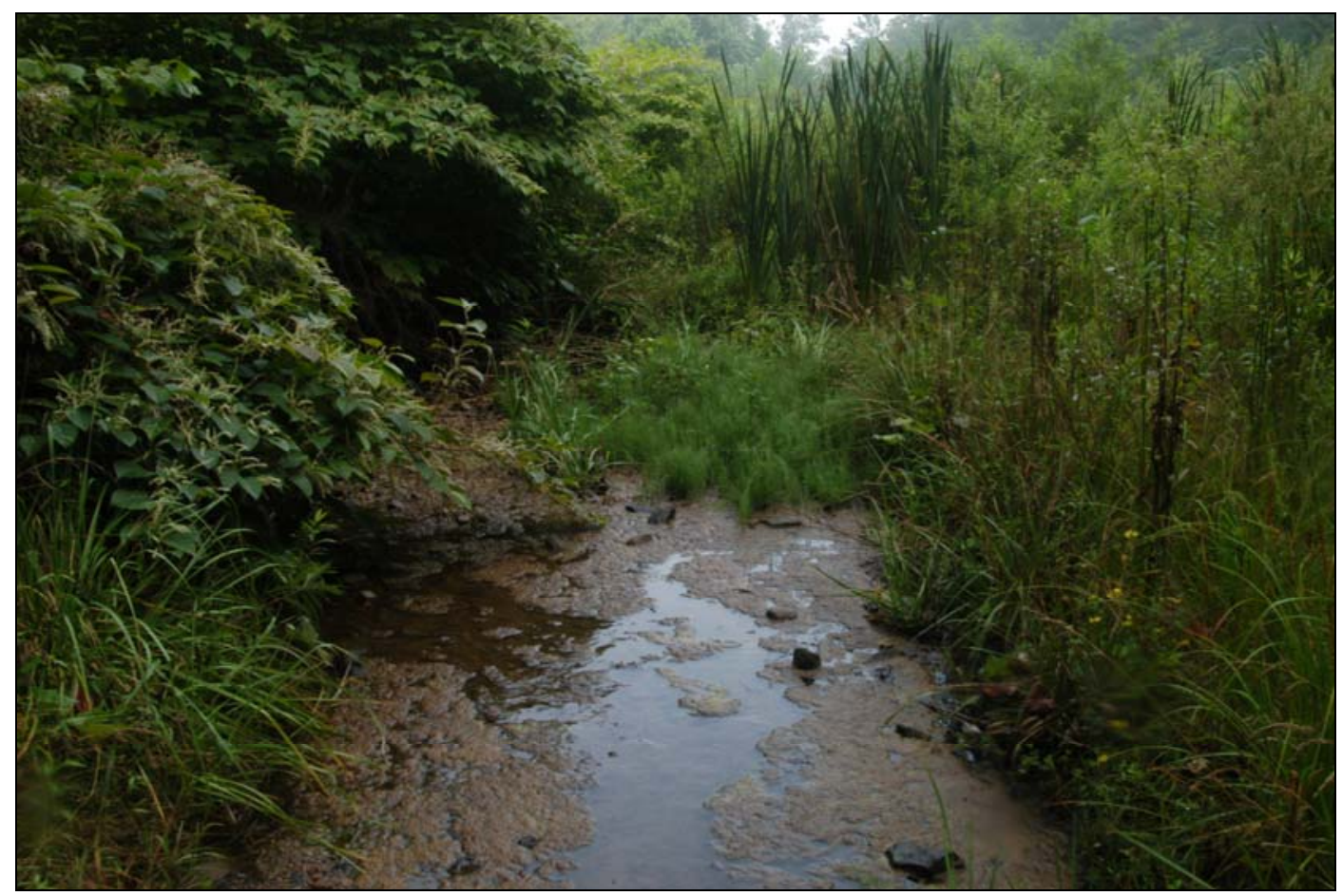

(b)

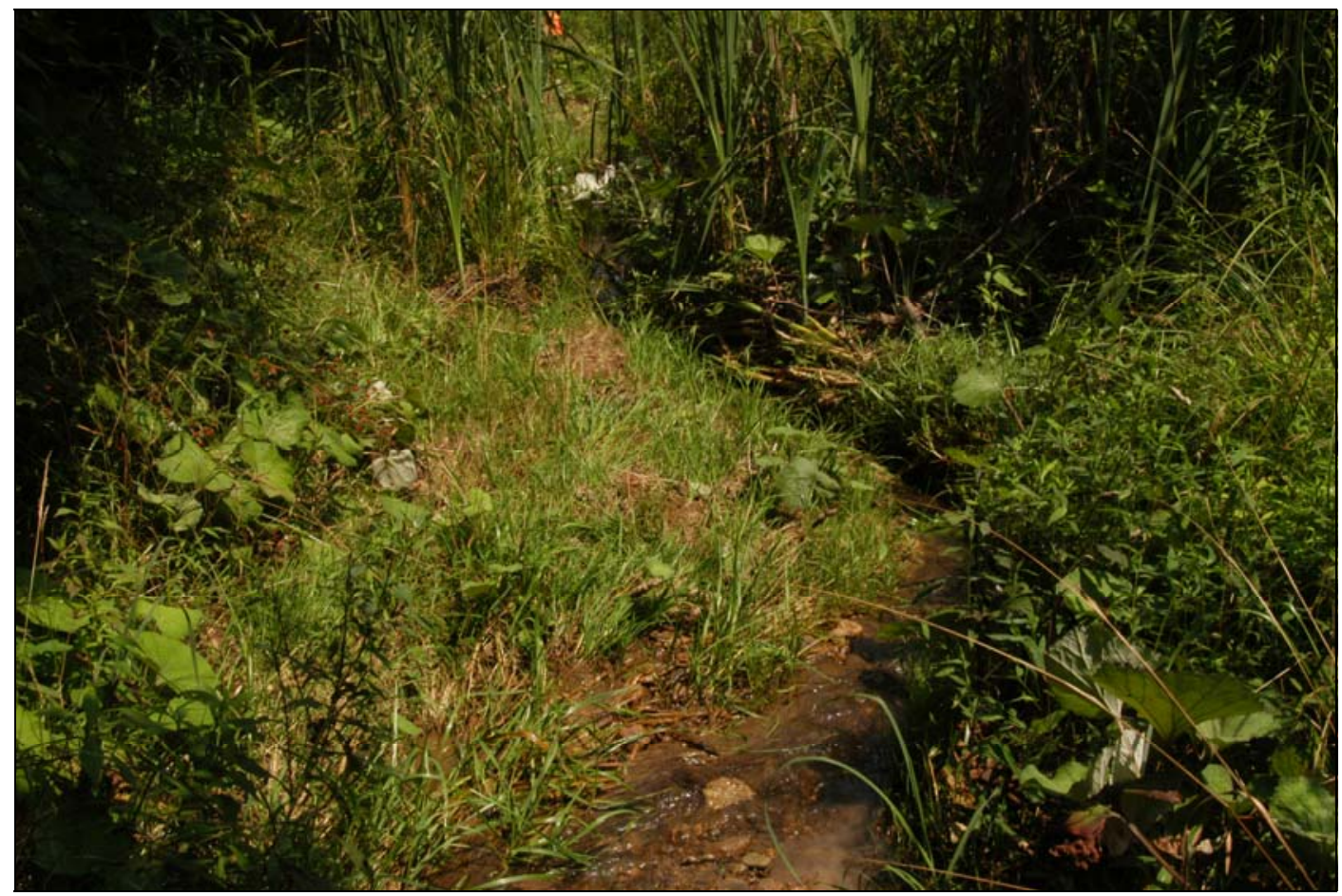

FIGURE 45 - (a) Newly Evolving Morphology at Head of Reclaimed Sediment Pond Resembling Wetlands and (b) a Small Meandering Channel Looking Downstream (HF 4,HF 9); Note That Figure 45a Represents the Morphology of Figure 44a Looking Upstream After the Passage of Approximately 3 Years 


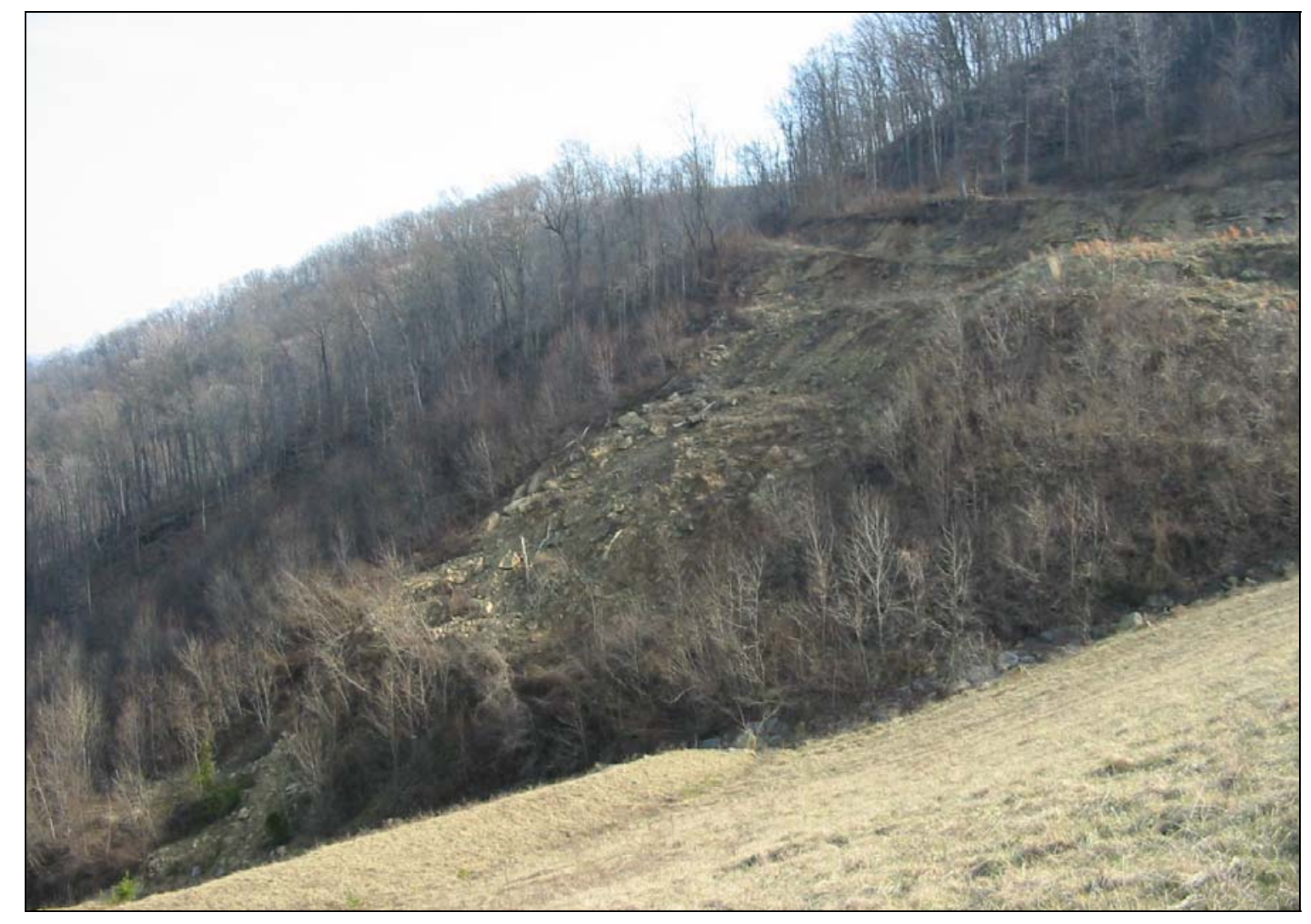

FIGURE 46 - Disturbed and Displaced Debris Indicating a Recent Landslide on a Hillside Adjacent to HF 11

Co-existing with landsliding and also contributing sediment was the less episodic process of rill erosion on disturbed hillslides and backfilled slopes (Figure 48). As defined by Knighton (1998), rills are non-permanent microchannels, typically 2 to 12 inches in width and up to 12 inches deep, evolving from concentrated overland flow. Slopes disturbed by mountaintop mining and hollow fill construction operations on slopes of backfilled areas may initially be left with little or no vegetal cover, increasing material erodibility through a lack of root reinforcement and flow erosivity through a lack of retardance or interception. Rill erosion on such slopes may contribute $50 \%$ to $90 \%$ of the total sediment removal (Knighton, 1998). Rill development may also be 
(a)

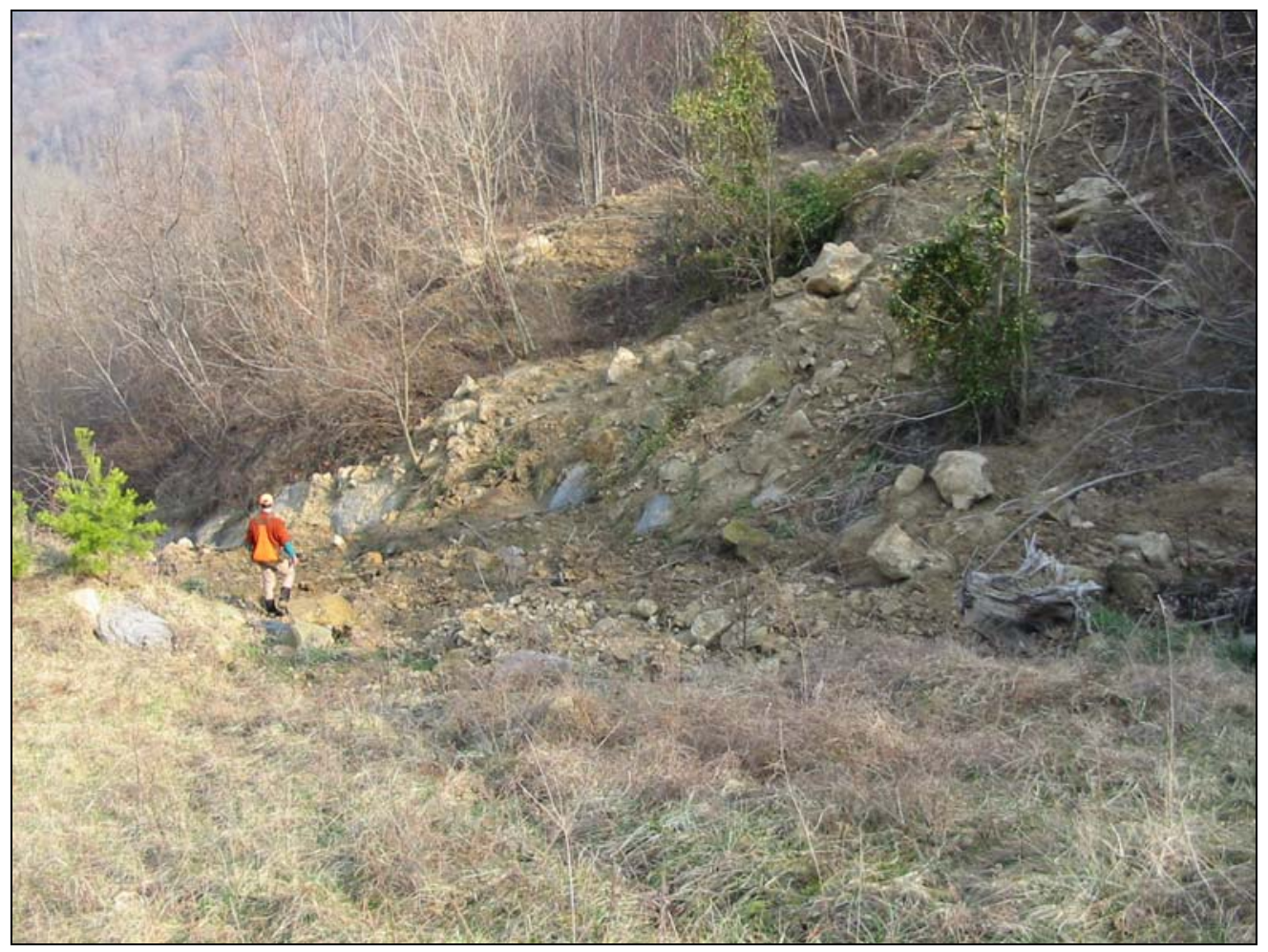

(b)

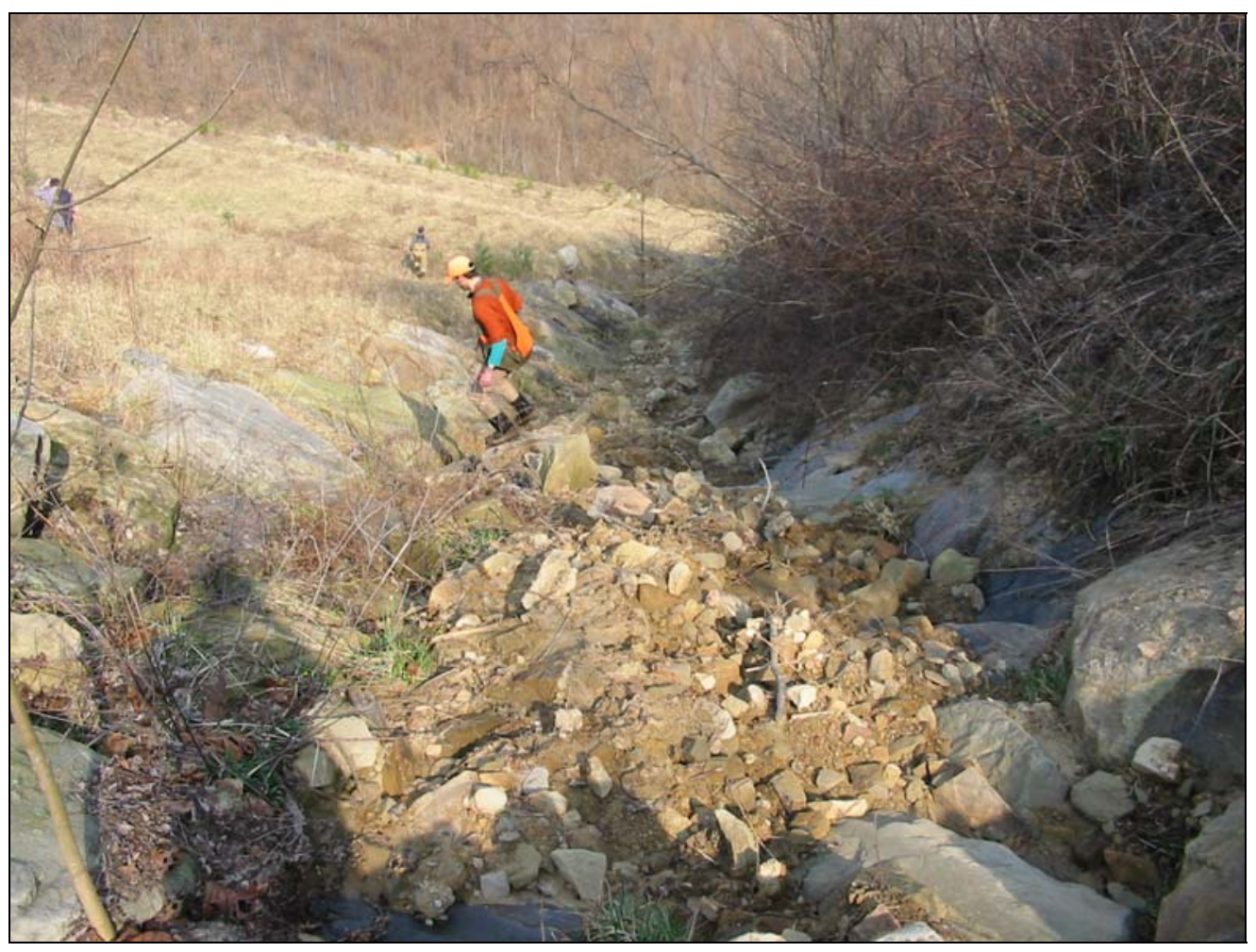

FIGURE 47 - Slope Debris (Soil and Rock) Introduced to the Adjacent Groin Ditch as a Result of the Landslide Indicated in Figure 46 


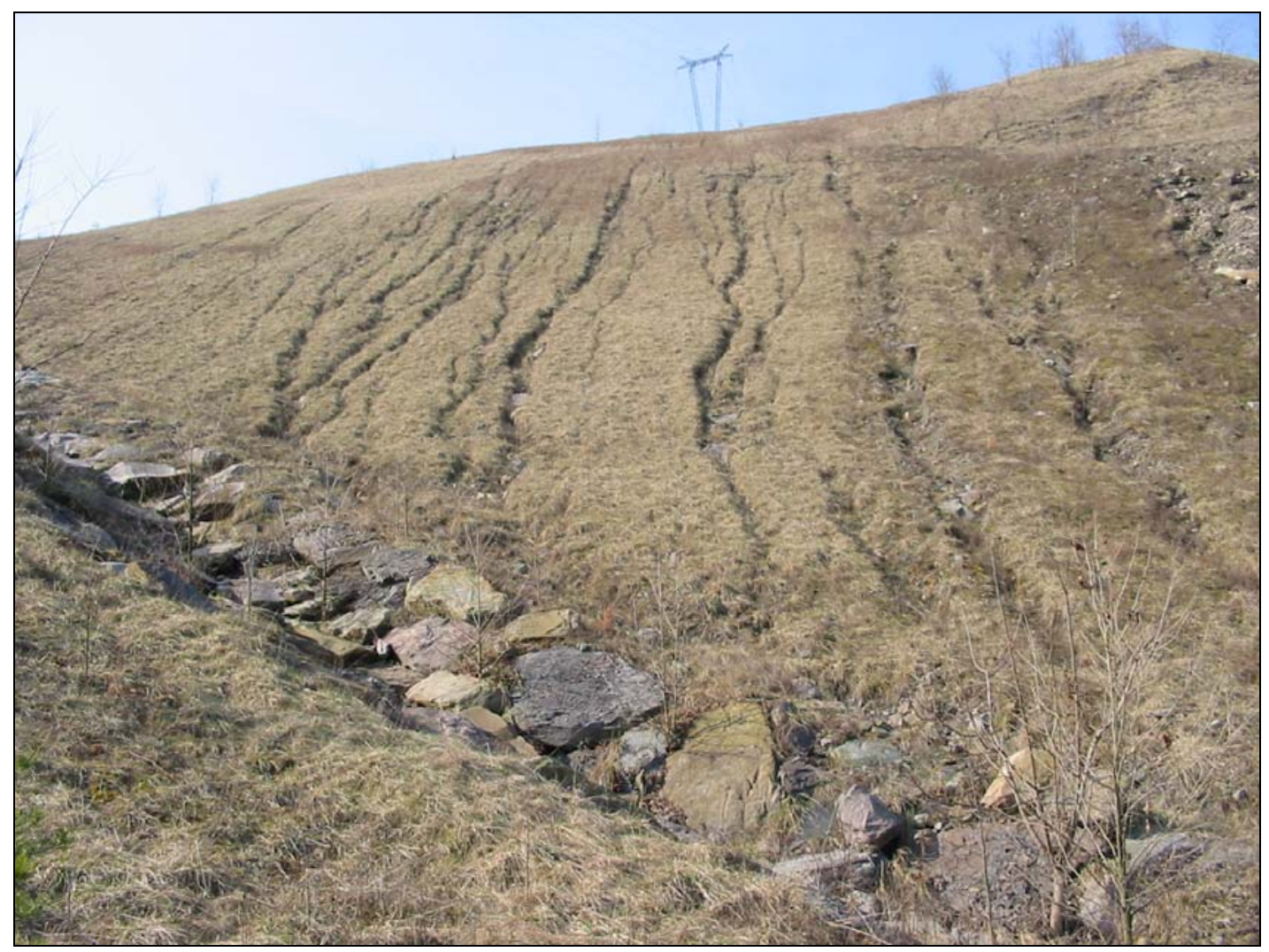

FIGURE 48 - Evidence of Rill Erosion on a Backfilled Slope Adjacent to HF 11

accelerated due to lowered hillslope base levels created by groin ditch construction or vertical degradation.

While not a specific mechanism of sediment transport as are landsliding or rilling, settlement of the hollow fill material also alters the topography of the post-mining headwater system. This altered topography may be of geomorphic relevance due to its influence on preferential surface water flow paths. Specifically, groin ditch alignment based on a pre-settlement fill configuration may no longer represent the path of highest down-valley gradient most likely followed by surface water flow. Flow may consequently avulse from the groin ditch as was observed on Arches 2 (Figure 49a). Settlement was also inferred in observation of localized fill depressions (Figure 49b). 
(a)

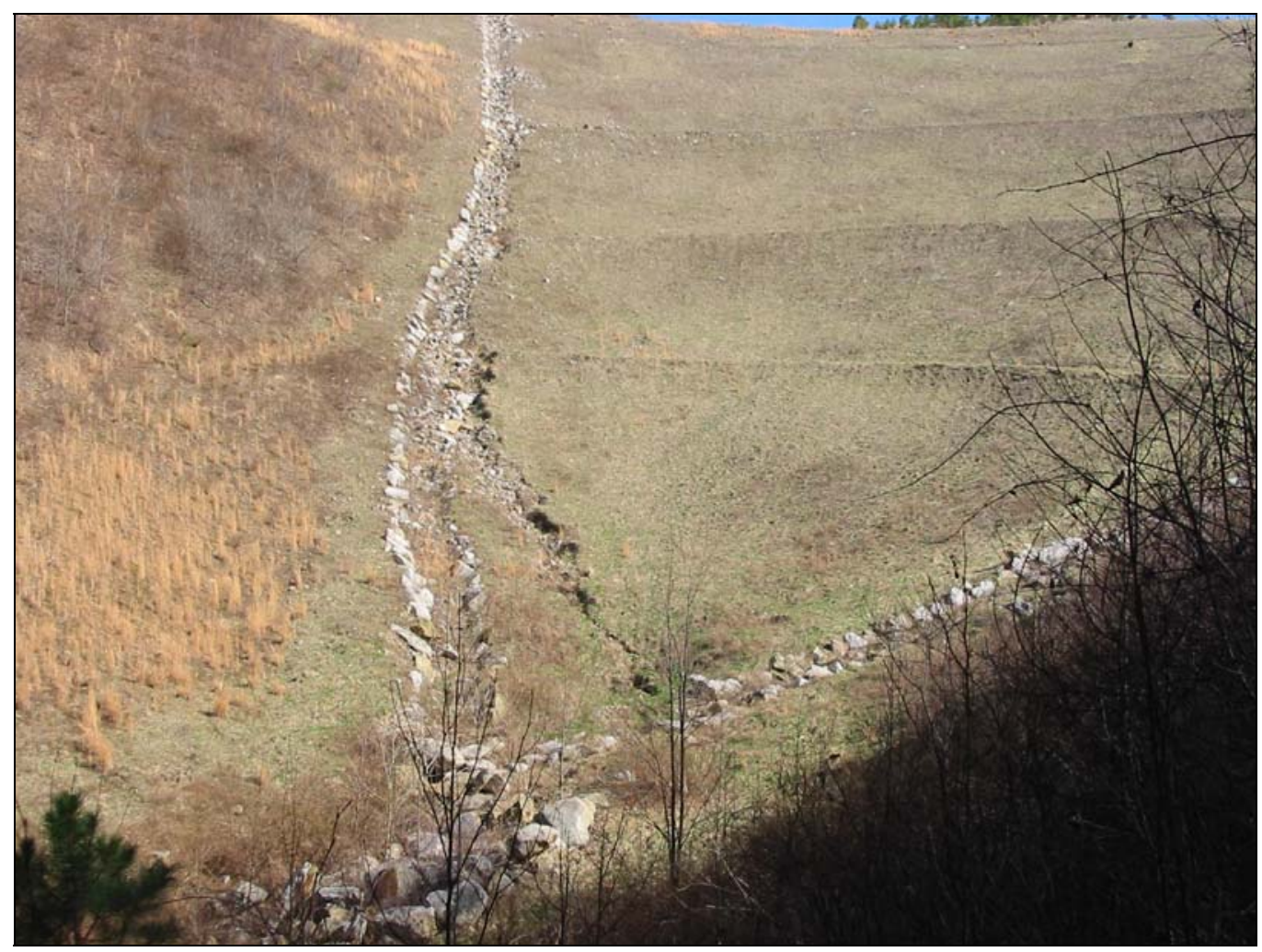

(b)

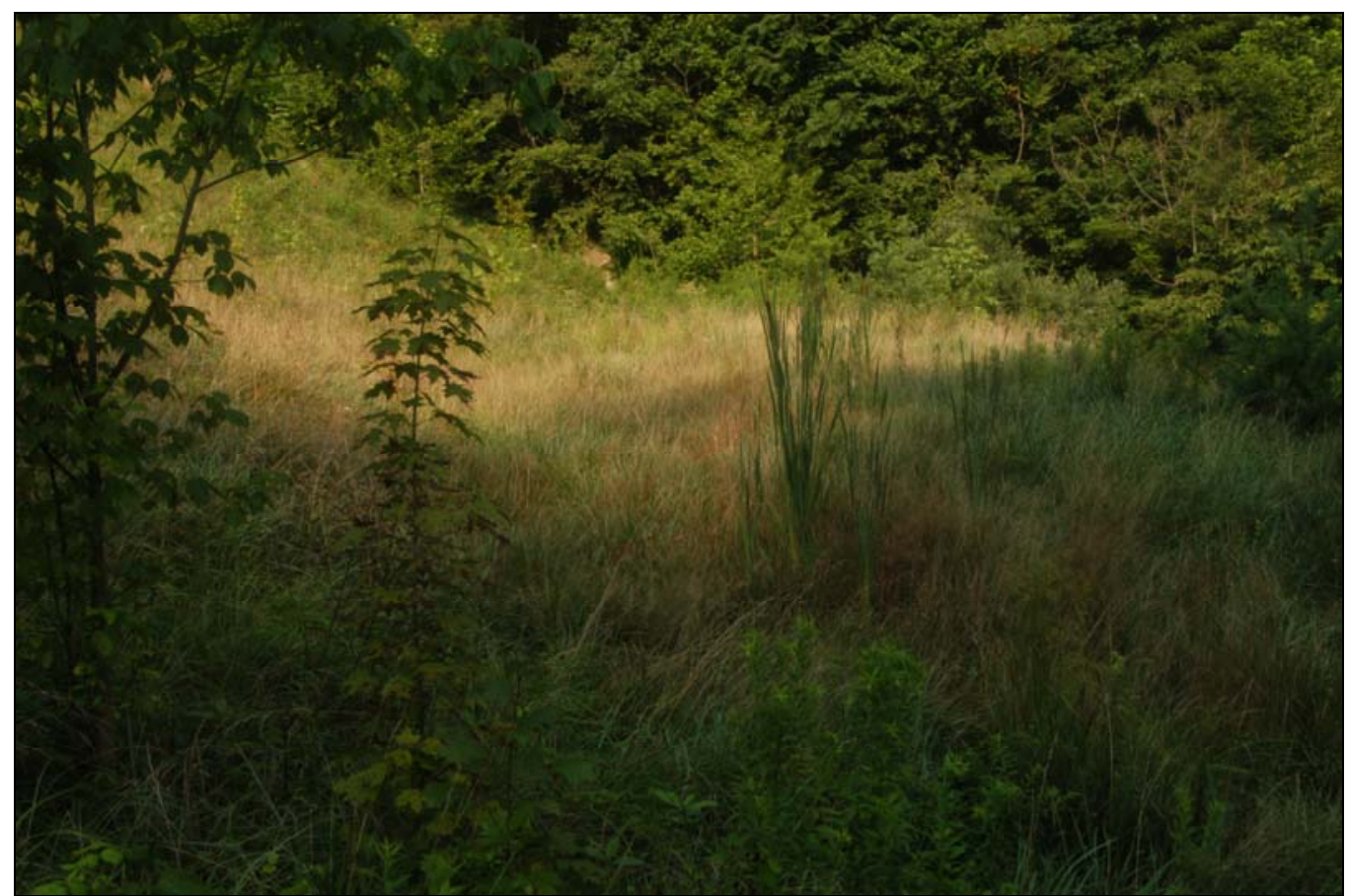

FIGURE 49 - (a) Avulsion from Groin Ditch Channel of Arches 2 and (b) Local Depression Capable of Supporting Cattails on HF 11, Indicating Possible Differential Fill Settlement 
The weight of deep masses of spoil is significant, leading to self-consolidation through mechanisms such as rock crushing at points of contact and creep settlement (Krebs and Zipper, 1997). In addition to creating a condition of significant self-loading, the large depths typical of hollow fills may induce significant settlement simply due to the fact that a greater amount of material is available to settle. Differential settlement of a hollow fill may be possible due to the steep valley hillslopes on which most fills are founded. The magnitude of potential settlement may vary across the surface of the fill with maximum settlement occurring at the centerline of the fill.

Additional factors influencing fill settlement may be the presence of non-durable rock, water within the fill, and the method of material placement. The presence of either non-durable rock, although limited to less than $20 \%$ by state law (405 KAR 1:141), or subsurface water may reduce the structural integrity of rock within the fill, thus leading to excessive intergranular crushing (Krebs and Zipper, 1997). The magnitude of fill settlement may also depend on the method of material placement. When material is placed in individually compacted lifts, compaction effectiveness decreases with lift thickness. Increased settlement may be a possibility when fills are constructed with fewer and thicker lifts. Durable rock fills constructed with a single lift may be particularly prone to settlement.

Material subjected to the observed mechanisms of sediment transport may be that of natural or disturbed hillsides, or it may originate from newly exposed blasted overburden. Forces driving the weathering of hillside material act upon sandstone and shale of the overburden formerly protected from such forces. Subsequently accelerated sediment production may result as natural sediment supply is augmented by the rapid 
breakdown of this freshly exposed rock. Particularly prone to rapid weathering is nondurable shale. While predominantly composed of durable sandstone boulders, groin ditch rip-rap included shale boulders. Such boulders were observed to be rapidly deteriorating and contributing to the apparently fluvially-mobile sediment found filling the interstices of the boulder lining and collected in backwater areas created by boulders (Figure 50).

\section{Considerations of Driving Factors}

Observed geomorphic processes are constituent mechanisms of the overall process of morphologic evolution occurring within filled headwater valleys. While previously occurring naturally, this evolutionary process has been reset by the alteration of driving factors, including catchment hydrology, channel substrate, sediment supply, and, most obviously, landscape morphology.

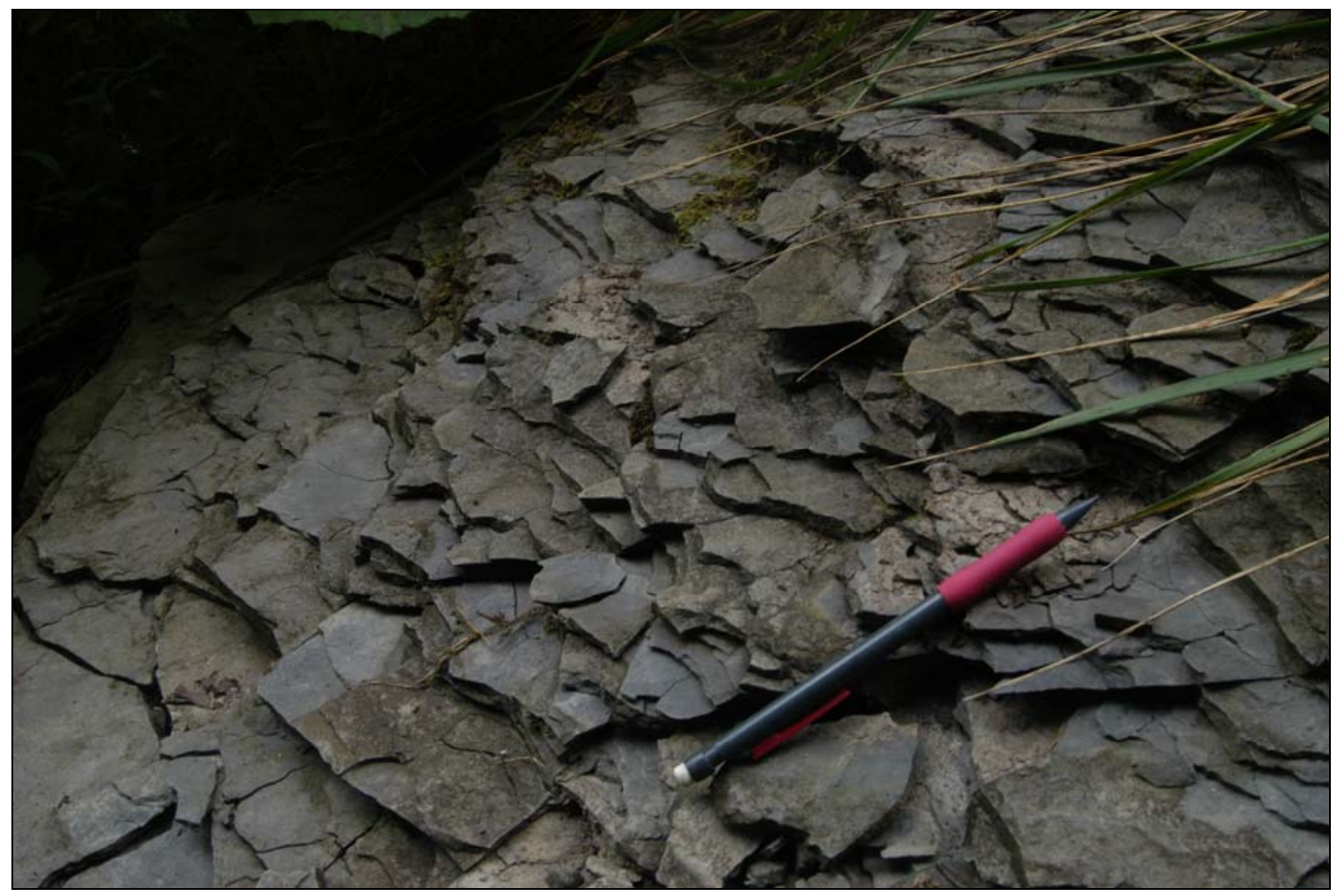

FIGURE 50 - Weathering Shale Boulder Lining a Groin Ditch of HF 2 and Slaking to Produce Fluvially-Mobile Sediment 
Within drainage-ways, directly altered channel form was observed to be evolving in response to fluvial erosional forces. On hollow fills and the adjacent hillsides, observed geomorphic evolution was in response to gravity and the shear force of overland flow. Examples of evolving, directly altered channel morphology include: constructed knickpoints at reclaimed sediment pond embankments and rock check dams, reconstructed stream reaches across the reclaimed sediment pond areas, and groin ditches replacing buried stream reaches. Altered hillslope morphology includes anthropogenically-imposed landforms in the form of hollow fills and changes to slope base levels.

The potential for geomorphic activity associated with altered morphology and sculpting forces has been addressed to some extent in hollow fill construction practice. Observed evidence of measures taken to prevent fluvial erosion include: reconstructed channels armored with durable, relatively immobile rock and lessened gradients of former sediment pond embankments after apparent re-grading. Measures to prevent altered evolution of hillslopes and the hollow fills themselves were observed to include re-vegetation of disturbed areas, re-vegetation of the hollow fills and backfilled areas, and permitted plans including analyses of hollow fill structural stability. Such measures were implemented under regulations contemporary to the date in which the hollow fills were permitted (Table II) and may not be representative of current techniques. Current techniques and future stream restoration efforts should continue to account for the geomorphic implication of these direct morphologic alterations and improve upon techniques that were observed to be insufficient at the visited study sites. 


\section{Consideration of Observed Processes}

Consideration for the factors driving geomorphic processes logically stems from concern for the implication of these processes. Implications possibly avoided or lessened in severity by stream restoration efforts include those detrimental to the aquatic ecosystem or hollow fill stability. Such undesirable impacts may be consequences of fluvial or hillslope-related geomorphic processes.

While the observed fluvial processes were likely instigated by direct alterations to headwater stream morphology, other factors may be responsible and warrant consideration. For example, increased runoff from areas disturbed by mining may increase sediment transport rates and subsequent degradation in downstream reaches. Additionally, alternative factors may be of non-mining origin, such as the downstream straightening of streams to facilitate road construction or residential or agricultural development. As described by Knighton (1998), channel straightening increases gradient and subsequently leads to the headward migration of a knickpoint. Natural processes such as the introduction of landslide debris into the channelway may also initiate channel incision (Rodolfo, as cited in Schumm, 1999).

\section{Fluvial Processes}

Specific detrimental impacts that may potentially result from the observed fluvial processes are those characteristic of bed degradation or channel incision. Ecologic implications may include the loss of habitat diversity and lowered water quality. The diversity of stream morphology and that of the habitat it provides are reduced during

channel degradation. High shear stress within the incised channel results in the loss of small gravel and the bed forms it creates, and bank failure diminishes marginal habitat. 
This simplification of channel form reduces the variety of ecologic niches required for a biologically diverse aquatic ecosystem. Further ecologic impacts may occur downstream. Fine-grained sediment from the degrading bed and failing banks of the incising reach may be transported as suspended load, decreasing downstream water quality and filling the interstitial spaces of gravel required for macro-invertebrate communities and spawning fish populations (Brookes, as cited in Simon and Darby, 1999). If channel degradation occurs within the reclaimed sediment pond reach, the impounded sediment wedge may erode and serve only as a temporary storage site for the constituent finegrained sediment.

The erosive nature of observed fluvial processes may also jeopardize hollow fill structural stability. Bed degradation propagating into groin ditches may result in the mass movement of spoil material after groin ditch bank failure. Slope stability of the hollow fill may be compromised due to the resulting alteration of fill geometry.

\section{Hillslope Processes}

The observed hillslope processes also merit consideration by the stream restorer for ecologic and structural reasons. Ecologic reasons stem primarily from the increased sediment load supplied to downstream reaches. Rilling on disturbed hillsides and accelerated landsliding may make large amounts of sediment available for fluvial transport. Downstream deposition of this sediment may result in the loss or alteration of aquatic habitat.

Structural reasons for considering the observed hillslope processes stem from their interrelationship with the fluvial processes of groin ditches. Landslides naturally occurring on the steep hillsides, or perhaps instigated by mining practices, may introduce 
flow-obstructing debris, causing avulsion of surface flow onto the face of the hollow fill. Erosion of fill material may occur as a new channel is formed through incision into the face of the hollow fill. Additionally, the presence of surface water on the face of the fill after flow avulsion may lead to increased infiltration of water into the fill. Infiltrated subsurface water may compromise fill stability due its deleterious effect on fill material shear strength. Fill subsidence may have a similar effect on the preferential flow path of surface water.

\section{E. Restoring Natural Morphology}

The threats to ecological stability or hollow fill structural integrity posed by geomorphic processes may be ameliorated by stream restoration efforts. Such efforts may entail redesigning the morphology characteristic of the observed groin ditches and reconstructed stream reaches in favor of forms more representative of natural channel morphology. More natural channel morphology would be more likely to evolve in such a way as to remain supportive of the pre-mining ecosystem and preserve the structural integrity of hollow fills. Observed aspects of groin ditch morphology differing from those of the original stream (see Figure 51) included substrate comprised of large, uniform riprap and triangular or trapezoidal cross-sectional geometry. This substrate and the associated cross-sectional geometric configuration are designed to apply uniformly for the entire length of channel rather than replicating the downstream continuum of morphological transition typical of natural headwater streams. If a desire exists to abandon typical groin ditch design in favor of that which more accurately re-creates viable headwater stream reaches on hollow fills, consideration should be given to premining morphology and its longitudinal variation. 
(a)

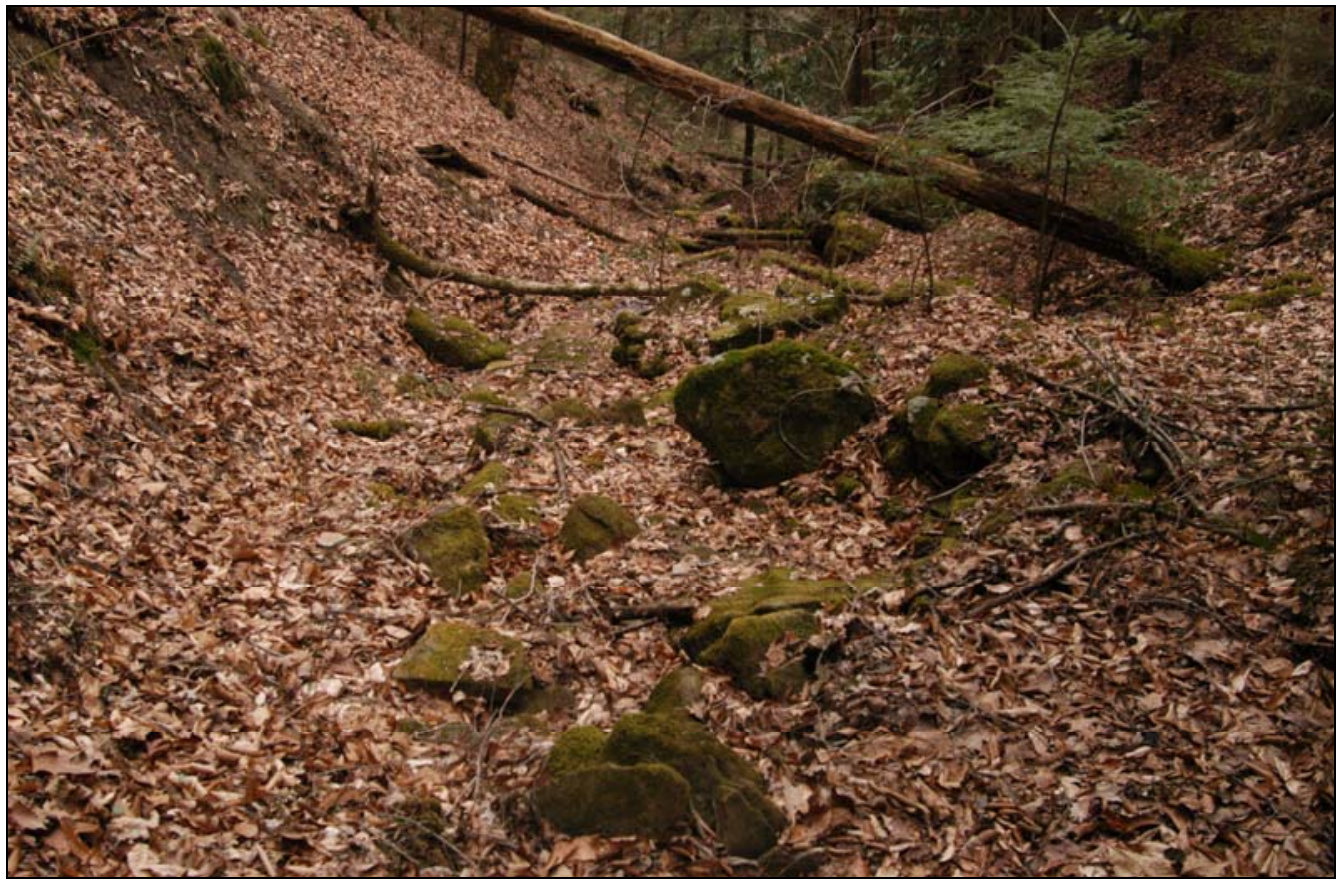

(b)

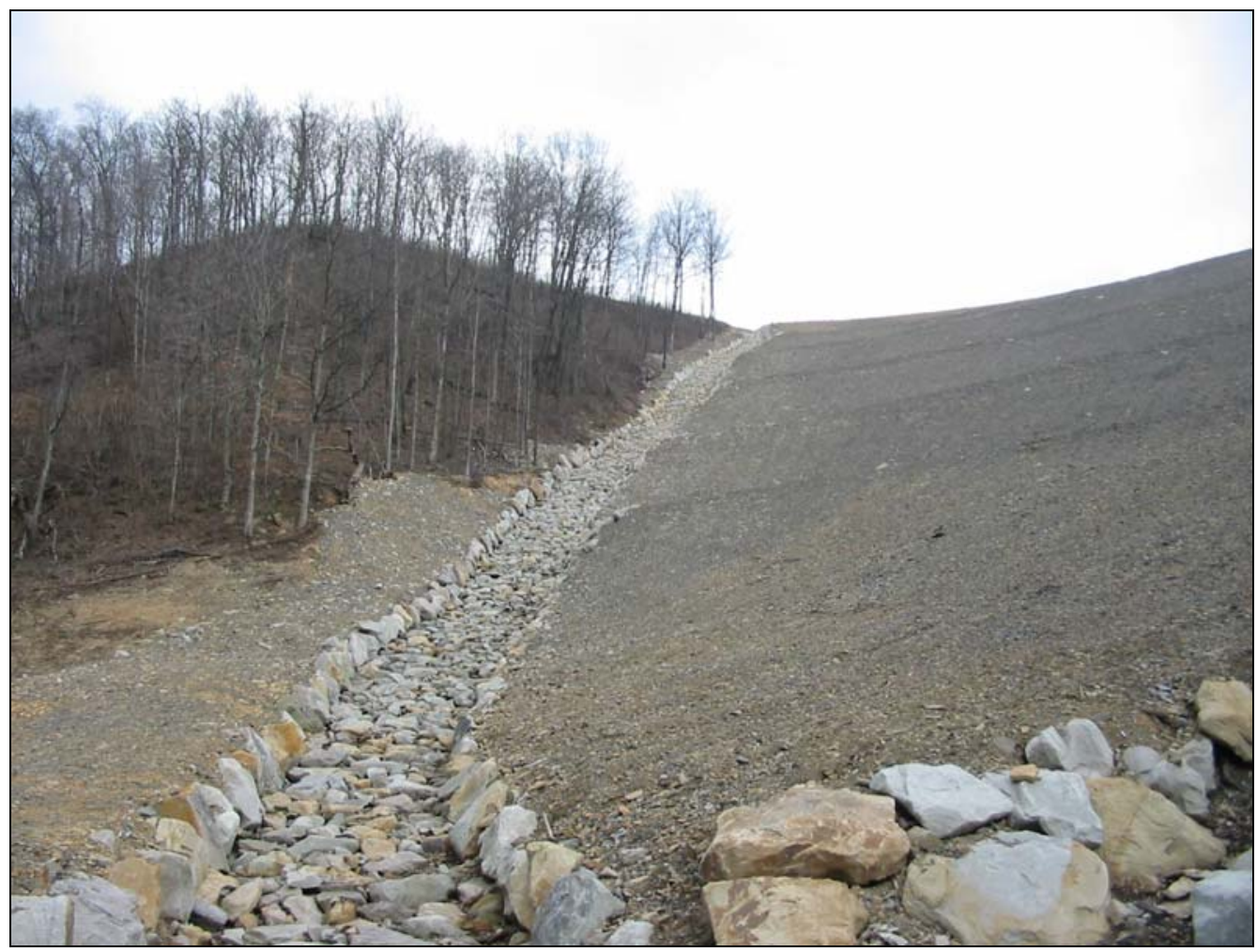

Figure 51 - Comparison of (a) Colluvial and (b) Groin Ditch Morphologies; (a) Represents a Stream Within the Lilley Cornett Woods of Letcher County, Kentucky, at a Drainage Area of Approximately 19 Acres and an Approximate Slope of $30 \%$, Both Measurements Similar to Those of the Downstream Section of the Groin Ditch of a Hollow Fill Near Study Sites (Permit No. 898-0349) 
The longitudinal variation in morphology is largely dependent on channelforming discharge and channel gradient (Montgomery and Buffington, 1997), two factors differing from their pre-mining states along constructed groin ditches. Topographic alterations, changes to land surface conditions, and subdivision of drainage area by two channels may alter channel forming discharge, and current hollow fill configurations are necessarily associated with channel gradients shown to differ from those previously existing. Given such alterations, or assuming such alterations will persist in future mountaintop mining practice, re-construction of the exact pre-existing morphology may not be appropriate. However, a more natural, stable morphology may still feasible for the altered conditions.

A regional analysis of morphological correlation to channel gradient and factors governing discharge for unimpacted headwater streams may aid in the selection of naturally stable alternative morphology for the altered conditions. In addition, such efforts must not overlook the correlation of morphology with locally varying factors outside of channel gradient and discharge such as valley-wall confinement, riparian vegetation, and large woody debris loading (Montgomery and Buffington, 1997). These factors may have a drastically altered influence within the impacted headwater system.

Using drainage area as a surrogate measure for discharge, Montgomery and Buffington (1997) performed such a regional analysis in their classification of reach-scale morphologies for a watershed in the state of Washington (in this context, "reach" is defined as a stream segment with uniform morphology at least several channel widths in length). Although pertaining to a different geographic location, this study may be useful as a template for a similar analysis within the regions prone to mountaintop mining and 
hollow fill construction. Montgomery and Buffington's results, represented here as Figure 52a, give an approximate quantitative measure of the correlation between reachscale morphologies, slope, and drainage area. From these results, an idealized longitudinal profile was developed showing the general distribution of morphologies from hillslopes downstream through the channel network (Figure 52b).

This method of characterizing reach-scale channel types based on bedform morphology is of particular relevance to the current study in that it relates stream morphology to geomorphic processes. Characterizing reaches on such a basis may allow their sensitivity to alteration of these processes (as with mountaintop mining and hollow fill construction) to be predicted. Montgomery and Buffington's channel types generally vary with gradient, reflecting the general trend of increasing organization and fining of channel substrate in the downstream direction. Upstream reaches are most often classified as colluvial reaches due to the domination of channel substrate by material input under the action of gravity and slope wash from adjacent hillslopes. As slope decreases in the downstream direction, geomorphic processes organize supplied sediment into cascade, step-pool, plane-bed, pool-riffle, and finally, dune-ripple reach types. Bedforms characteristic of these reach types provide the hydraulic roughness necessary to balance effective sediment transport capacity with sediment supply (Montgomery and Buffington, 1997).

Also included in this classification scheme are bedrock reaches developed in response to localized changes in the relationship between sediment supply and transport capacity. Bedrock reaches may occur at the outcropping of a resistant layer in the stratigraphy or develop after recent scouring by catastrophic events (Montgomery and 
(a)

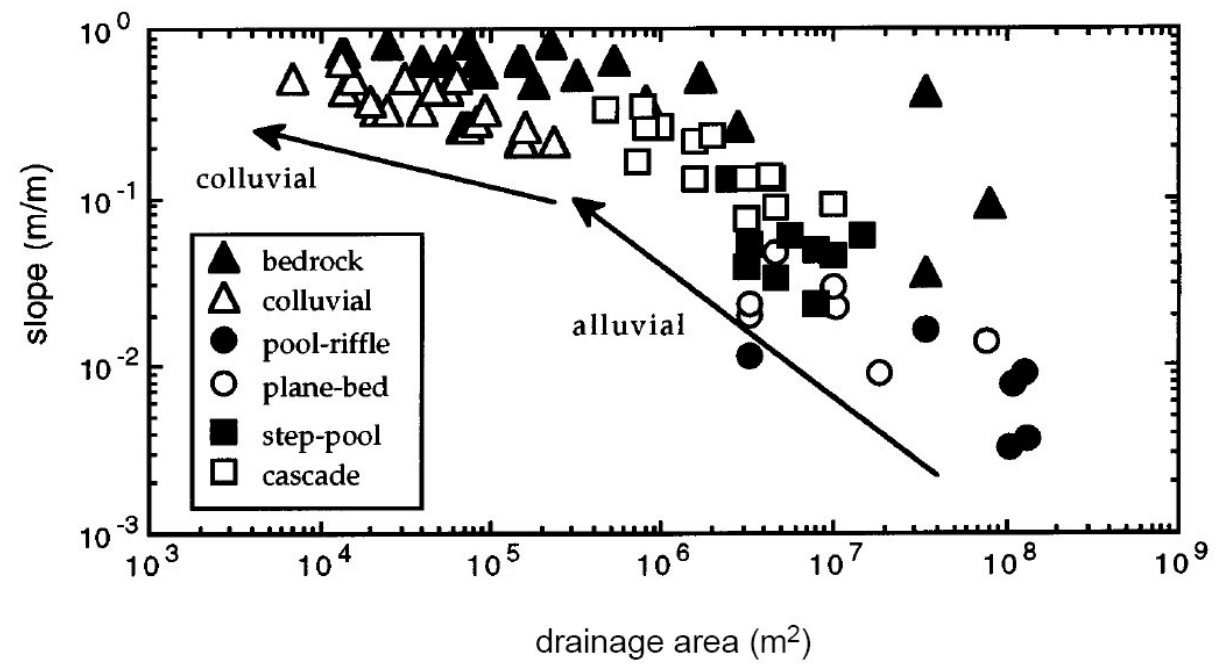

(b)

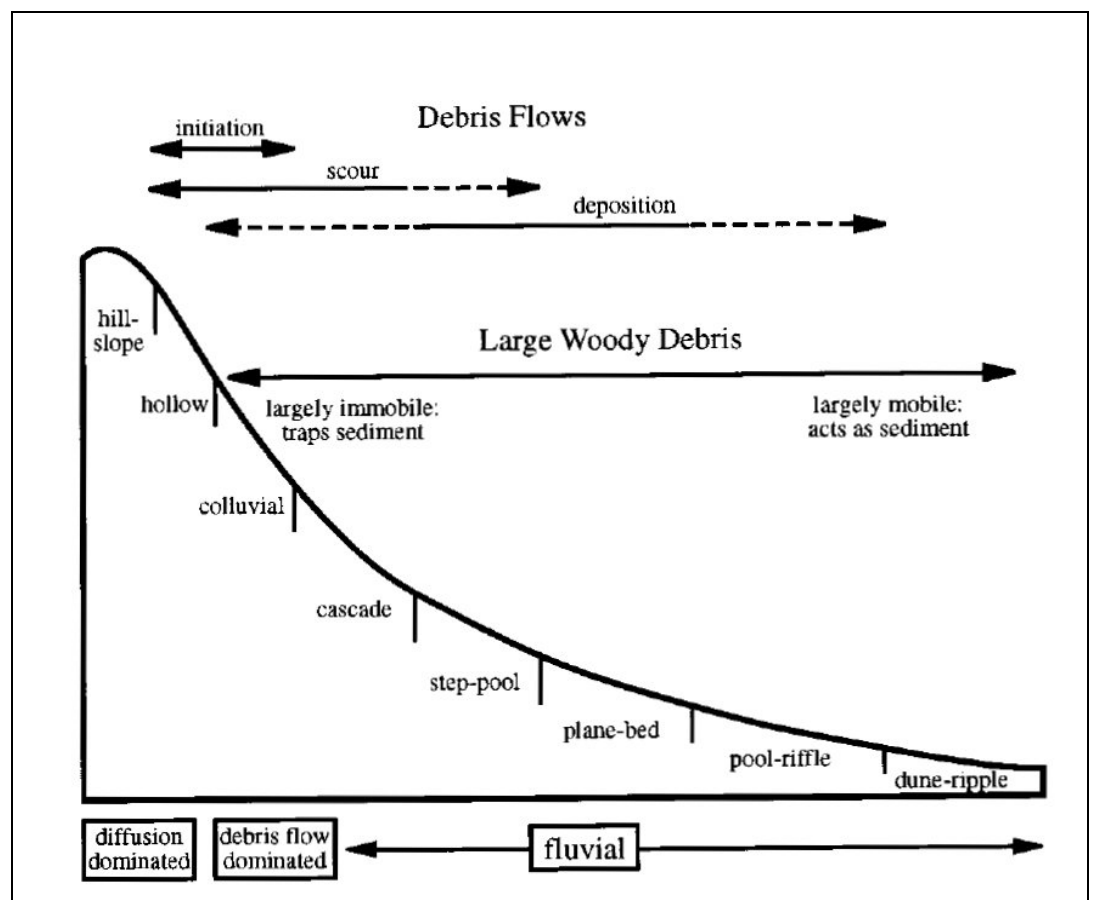

FIGURE 52 - (a) Drainage Area vs. Reach Slope for Channels in a Washington State Watershed; the Inflection Between Colluvial and Alluvial Morphologies may Reflect a Difference in Geomorphic Processes; (b) Idealized Longitudinal Profile from Hillslopes and Unchanneled Hollows Downslope through the Channel Network Showing the General Spatial Variation of Channel Types and Controls on Channel Processes in Mountain Streams (from Montgomery and Buffington, 1997, pp. 603-604) 
Buffington, 1997). Another localized reach type identified by the authors was forced morphologies. Like bedrock reaches, channel segments with forced morphologies are the result of localized deviations from the down-gradient trend in reach type. This localized deviation may come in the form of in-channel large woody debris. Of particular importance in forested watersheds, the presence of such debris may obstruct flow and subsequently cause local deposition or scour. Forced morphologies often take the form of step-pools or riffle-pool sequences.

While the reach types identified by Montgomery and Buffington may very well exist within the region considered by the current study, the classification scheme was developed and tested in reference to montane streams of the Pacific Northwest. Differences in regional relief, climate, geology, or geomorphic history may lead to deviation from Montgomery and Buffington's classification in the context of eastern Kentucky's Appalachian streams.

As with groin ditches, recognition of pre-mining morphology and its controlling factors may aid in improving restoration efforts of streams in areas of reclaimed sediment ponds (Figure 53). Unlike the drastically altered slope and convexity of hollow fill groin ditches, channels constructed in the vicinity of sediment ponds may be returned to their approximate original state, depending on adequate removal of impounded sediment, thereby allowing for restoration of the native morphology. 
(a)

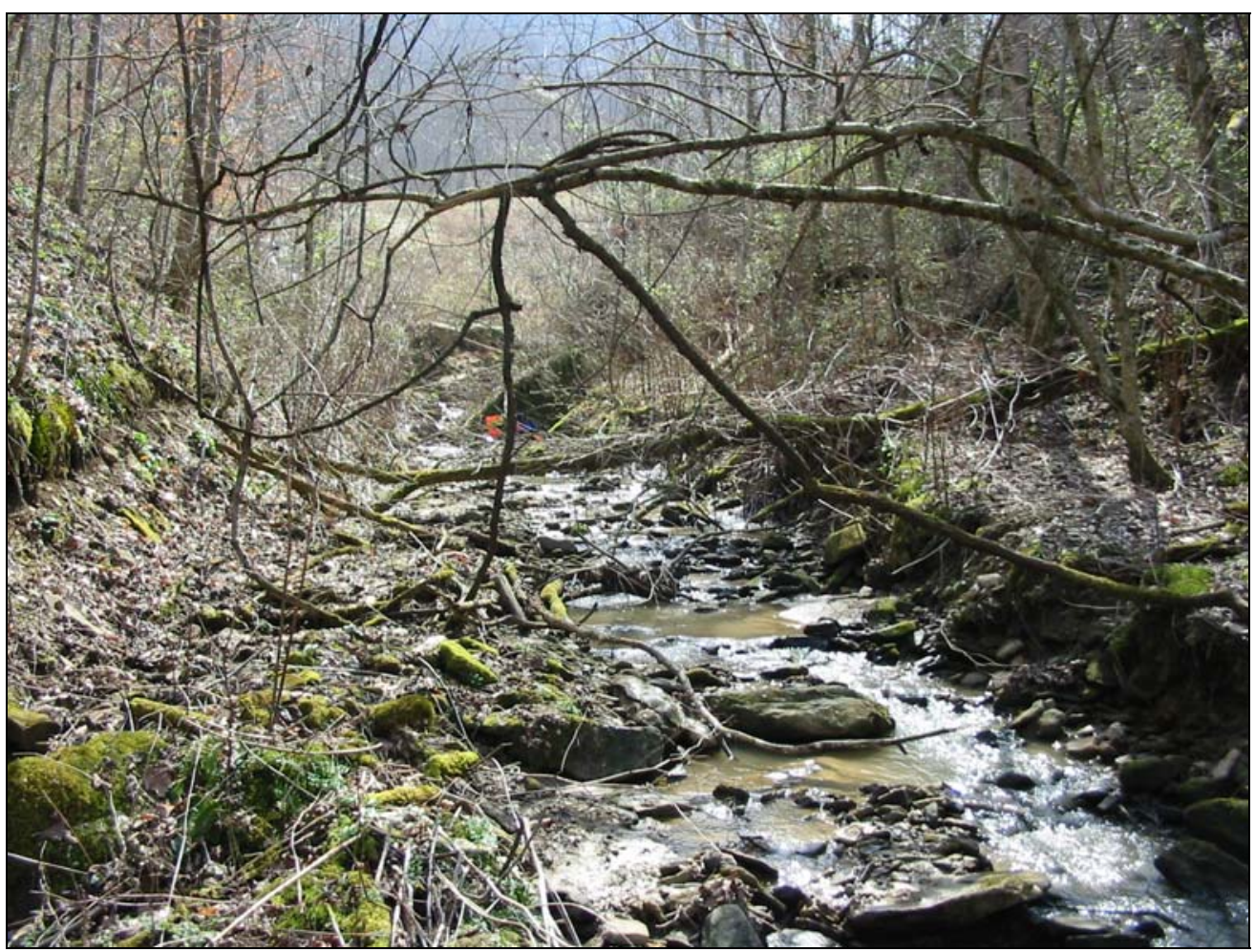

(b)

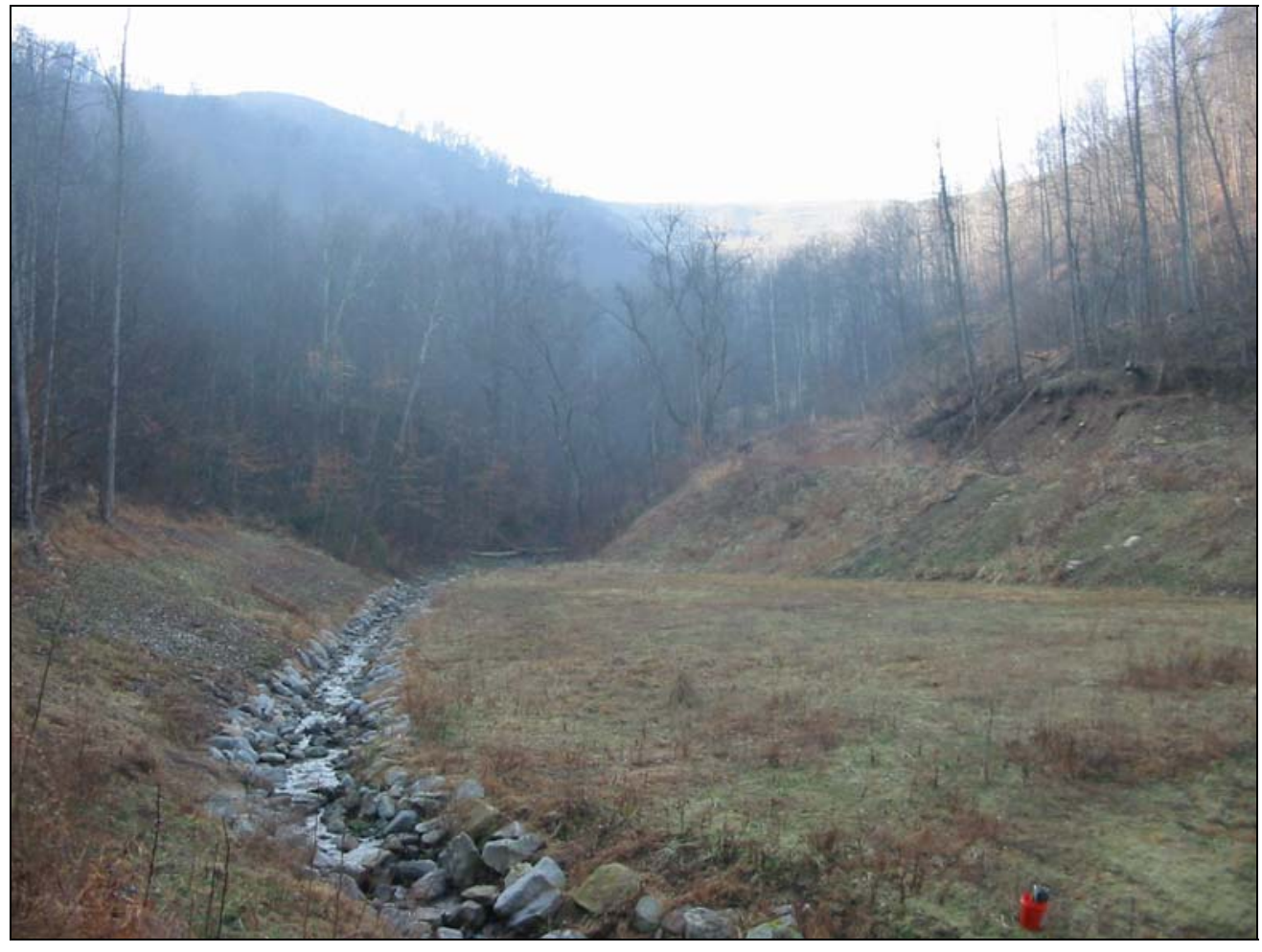

FIGURE 53 - Comparison of (a) Plane-Bed and (b) Reconstructed Channel Morphology (Looking Upstream) Observed Directly Downstream (a) and Across (b) the Reclaimed Sediment Pond of HF 11 


\section{CONCLUSIONS AND RECOMMENDATIONS}

Within the Appalachian hills of eastern Kentucky, large-scale coal mining operations are directly altering the headwater landscape through the construction of hollow fills. These man-made landforms and their associated in-stream structures disrupt a long-term, continuous morphologic evolution driven by the natural interaction of erosive forces and material of the earth's surface; the altered physical form of the filled valley is no longer a product of geomorphic processes. Repercussions of this disruption manifest as post-mining channel morphology, hillslopes, and hollow fills actively evolving in response to continued erosive forces. Aquatic functionality and hollow fill stability may be jeopardized by this condition, yet may be preserved through efforts to restore or re-create channel morphology more representative of the natural headwater stream.

The success of such stream restoration efforts depends largely on the incorporation of geomorphic considerations. Fluvial and hillslope geomorphic processes and their interaction are inevitable and must be accommodated in restoration design. Through an analysis of longitudinal stream profiles, the current study has presented practical geomorphic considerations regarding discrepancies between permitted hollow fill plans and as-built hollow fills. Additionally, pre- and post-mining longitudinal profiles were compared to generally investigate the physical differences that may instigate morphologic evolution. A field investigation of select headwaters impacted by hollow fill construction revealed active post-mining morphologic evolution of streams 
and the interrelated hillslopes driven by discernable geomorphic processes. The examined hollow fills were constructed under regulations which pre-date those currently in place; nevertheless, the observations and considerations derived from them may be useful in the development of stream restoration practices in mined areas.

Coarse estimates of average groin ditch slopes, assumed to be linear, were calculated using profile endpoints for both the permitted design and as-built hollow fill configurations. Comparison of these two representations revealed that overall average slopes of plan profiles were similar to those constructed. However, an overall average slope comparison overlooks local longitudinal variations between the design and the constructed fill. Therefore, local slopes were calculated using a two-segment moving average technique. This analysis revealed that, in comparison to local slopes of plan profiles, as-built local slopes demonstrate less longitudinal uniformity. While over $50 \%$ of the local as-built slope measurements fell within $5 \%$ (absolute) of local plan slopes, the range of local variations was large.

These local variations of channel slope may or may not be correlated with longitudinal position. An example of correlation between characteristic variation and longitudinal position may be the possible toe concavity and headward convexity indicated by as-built slope plots. The size of the current data set precludes speculation on the reasons for this trend or the presence of those not identified here. The current study does, however, serve as a first step in determining the potential range in constructed slopes to be expected by the stream restorer in designing stable channel morphology. Further investigation of this potential range may be aided by topographic surveys that 
avoid error associated with the method of using aerial photographs to generate as-built profiles.

A general comparison of longitudinal profiles of hollow fill groin ditches and premining headwater streams reveals drastic differences in concavity. Slopes of pre-mining profiles characteristically increase in the upstream direction producing generally concave profiles. As-built profiles, on the other hand, are relatively uniform, and slopes seem to fluctuate randomly. Unlike the pre-mining profiles, as-built profiles do not reflect the presence of geomorphic processes, and groin ditches may consequently undergo some form of morphologic evolution. Such an evolution would, however, depend on other physical factors such as bed substrate and cross-sectional geometry. Field observations corroborated the findings of the longitudinal profile analysis and revealed additional physical characteristics potentially capable of instigating morphologic evolution.

Through field observation, the current study has identified several geomorphic processes that are occurring or may occur within headwater settings impacted by hollow fill construction. Fluvial processes were observed to be associated with bed degradation and channel incision. Unstable stream and groin ditch banks indicated the tendency for this morphologic instability to propagate upstream through the processes of headcutting. Headcuts were observed to have initiated at locations of high channel gradient and inferably high shear stress, such as the faces of former sediment pond embankments and abrupt drops at rock check dams. Rip-rap lining these high-gradient reaches was observed to have failed in preventing erosion of underlying fine-grained sediment and subsequent bed degradation. 
During stream restoration, removal of profile convexities imposed by mining practices may prevent headcut initiation and subsequent impacts to stream ecology and hollow fill stability. This may entail complete removal of the sediment wedge and former embankment of reclaimed sediment ponds. At rock check dams, impounded sediment should be similarly removed, and groin ditch construction should ensure that ditch base level does not coincide with elevation of an impounded sediment wedge but rather that of the original stream or bedrock.

Observed hillslope geomorphic processes included mass movement of slope debris via landsliding, rill erosion on hollow fills and backfilled areas, fill subsidence, and weathering of non-durable rock. Of prominent importance to stream restoration are those processes that may result in direct alteration of groin ditch morphology: landsliding and fill subsidence. Landsliding on hillsides occurs naturally and may persist in the presence of hollow fills. Due to the natural occurrence of this form of mass movement, efforts to altogether prevent landsliding may be of short-term success and possibly economically or ecologically costly. Alternative hollow fill designs that make allowances for this geomorphic process may be necessary to avoid flow obstruction and subsequent avulsion from groin ditches. Prevention of flow avulsion may lead to more enduring fill stability.

A conceptual alternative design might incorporate increased lateral confinement of groin ditches. While the original headwater stream would have been laterally confined by steep valley walls, the groin ditch lacks such confinement due to the adjacent, relatively flat face of the fill. Confinement may be achieved by shaping the hollow fill into a form that provides each groin ditch with its own small hollow. Such a 
configuration may involve an exaggerated ridge along the centerline of the fill with transverse sideslopes that are greater than the current $1 \%$ to $5 \%$ and that mimic those of the original hillside. The elevated center ridge of such a configuration may also prevent flow avulsion due to differential settlement.

Observed fill subsidence may also have the potential to cause flow avulsion. Composed of a single deep lift of spoil material, durable rock fills are a form of hollow fill particularly prone to differential settlement. During restoration efforts associated with groin ditches, fill type may be a consideration in assessing the risk of flow avulsion.

An intimate interrelationship exists between the physical form and sculpting forces of the headwater setting: hillslope and channel morphology influence and are shaped by erosional forces acting on hillsides and within headwater streams. Findings of the current study identify the presence of such an interrelationship within headwater settings morphologically altered by the construction of hollow fills. Observed postmining geomorphic processes associated with this persisting interrelationship may lead to morphologic conditions potentially detrimental to aquatic ecology and hollow fill stability. Stream restoration efforts that restore natural channel morphology may aid in lessening the severity of these conditions through consideration of geomorphic processes and influencing factors. 


\section{REFERENCES CITED}

Benda, L. and Dunne, T. 1987. Sediment Routing by Debris Flow. Erosion and Sedimentation in the Pacific Rim (Proceedings of the Corvallis Symposium). IAHS Publication 165: 213-223.

Benda, L., Hassan, M.A., Church, M., and May, C.L. 2005. Geomorphology of Steepland Headwaters: The Transition from Hillslopes to Channels. Journal of the American Water Resources Association 41:835-851.

Chow, V.T. 1959. Open Channel Hydraulics. McGraw-Hill Book Company, Inc.: New York, NY.

Davis, D.H. 1924. The Geography of the Mountains of Eastern Kentucky. Kentucky Geologic Survey: Frankfort, KY.

Dietrich, W. E. and Dunne, T. 1993. The Channel Head, in Beven, K., and Kirkby, M.J., eds., Channel Network Hydrology. John Wiley and Sons Ltd: Chichester, England.

Dietrich, W.E., Dunne, T., Humphrey, N.F., and Reid, L.M. 1982. Construction of Sediment Budgets for Drainage Basins, in Swanson, F.J., Janda, R.J., Dunne, T., and Swanston, D.N., eds., Sediment Budgets and Routing in Forested Drainage Basins: Portland Oregon, Pacific Northwest Forest and Range Experiment Station. U.S. Department of Agriculture, Forest Service Technical Report PNW141:2-23.

Doyle, M.W., Stanley, E.H., and Harbor, J.M. 2003. Channel Adjustments Following Two Dam Removals in Wisconsin. Water Resources Research 39(1).

Eller, R.D. 1995. Miners, Millhands, and Mountaineers: Industrialization of the Appalachian South, 1880-1930. University of Tennessee Press: Knoxville, TN.

Gomi, T., Sidle, R.C., and Richardson, J.S. 2002. Understanding Processes and Downstream Linkages of Headwater Systems. BioScience 52(10):905-916.

Hack, J.T and Goodlett, J.C. 1960. Geomorphology and Forest Ecology of a Mountain Region in the Central Appalachians. U.S. Geological Survey Professional Paper 347.

Henderson, F.M. 1966. Open Channel Flow. Macmillan Publishing Co., Inc: New York, NY. 
Hobba, W.A., Jr. 1987. Ground-water Study 5, in Richards, D.B., ed., Ground-Water Information Manual: Coal mine permit applications: U.S. Office of Surface Mining Reclamation and Enforcement Vol. 2, pp. 147-187. Available at http://www.ott.wrcc.osmre.gov/library/hbmanual/grdh20infovol2.htm, accessed October 2006.

Horne, J.C., Ferm, J.C., Caruccio, F.T., and Baganz, B.P. 1978. Depositional Models in Coal Exploration and Mine Planning in Appalachian Region. The American Association of Petrolium Geologists Bulletin 62 (12).

KAR (Kentucky Administrative Regulations). 2006. Available at http://www.lrc.ky.gov/ kar/titles.htm, accessed October 2006.

Knighton, D. 1998. Fluvial Forms and Processes: A New Perspective. Oxford University Press, Inc.: New York, NY.

Krebs, R.D. and Zipper, C.E. 1997. Foundations for Housing on Reclaimed Mined Lands. Powell River Project-Virginia Cooperative Extension Publication 460-115.

KYDF (Kentucky Division of Forestry). 2006. The Kentucky Forest Conservation Act. Available at http://www.forestry.ky.gov/programs/masterlogger/The+Kentucky+ Forest+Conservation+Act.htm, accessed October 2006.

KYDMP (Kentucky Division of Mine Permits). 2006. Kentucky Surface Mining Information System. Available at http://www.minepermits.ky.gov/sminformationsystem, accessed October 2006.

KYDMP (Kentucky Division of Mine Permits). 2006. Reclamation Advisory Memorandums (RAMs). Available at http://www.minepermits.ky.gov/statutesregs/RAMs.htm, accessed October 2006.

Leopold, L.B., Wolman, M.G., and Miller, J.P. 1992. Fluvial Processes in Geomorphology. Dover Publications, Inc.: New York, NY.

Lisle, T.E. 1987. Overview: Channel Morphology and Sediment Transport in Steepland Streams. Erosion and Sedimentation in the Pacific Rim (Proceedings of the Corvallis Symposium). IAHS Publication 165: 287-295.

Meikle, T. and Fincham, K. Jr. 1999. Truck/Shovel Spread-Design and Economic Criteria for Surface Mining. Proceedings of the Mining Reclamation Symposium (Morgantown, WV).

Montgomery, D.R. and Buffington, J.M. 1997. Channel-Reach Morphology in Mountain Drainage Basins. Geological Society of America Bulletin 109(5):596-611.

NOAA (National Oceanic and Atmospheric Administration) 2005. National Climatic Data Center. Available at http://www.ncdc.noaa.gov, accessed October 2006. 
Outerbridge, W.F. 1987. The Logan Plateau, a Young Physiographic Region in West Virginia, Kentucky, Virginia, and Tennessee. U.S. Geological Survey Bulletin 1620 .

Parker, G. 2006. 1 D Sediment Transport Morphodynamics with Applications to Rivers and Turbidity Currents. Available at: http://cee.uiuc.edu/people/parkerg/ powerpoint lectures.htm, accessed October 2006.

Paybins, K.S. 2003. Flow origin, drainage area, and hydrologic characteristics for headwater streams in the mountaintop coal-mining region of southern West Virginia, 2000-01. U.S. Water-Resources Investigations Report 02-4300.

Ponce, V.M. 1984. Engineering Hydrology: Principles and Practices. Prentice-Hall: Englewood Cliffs, NJ.

Price, K. and Leigh, D.S. 2006. Morphological and Sedimentological Responses of Streams to Human Impact in the Southern Blue Ridge Mountains, USA. Geomorphology 78:142-160.

Raitz, K.B. and Ulack, R. 1984. Appalachia: A Regional Geography: Land, People, and Development. Westview Press, Inc.: Boulder, CO.

Schumm, S.A. 1999. Causes and Controls of Channel Incision, in Simon, A. and Darby, S.E., eds., Incised River Channels: Processes, Forms, Engineering and Management. John Wiley and Sons Ltd: Chichester, England.

Simon, A. and Darby, S.E. 1999. The Nature and Significance of Incised River Channels, in Simon, A. and Darby, S.E., eds., Incised River Channels: Processes, Forms, Engineering and Management. John Wiley and Sons Ltd: Chichester, England.

Sinha, S.K. and Parker, G. 1996. Causes of Concavity in Longitudinal Profiles of Rivers. Water Resources Research 32(5):1417-1428.

Tsukamoto, Y. and Minematsu, H. 1987. Hydrogeomorphical Characteristics of a ZeroOrder Basin. Erosion and Sedimentation in the Pacific Rim (Proceedings of the Corvallis Symposium). IAHS Publication 165: 61-70.

USDA (U.S. Department of Agriculture). 1990. Soil Survey of Pike County, Kentucky. Soil Conservation Service.

USDA (U.S. Department of Agriculture). 1992. Soil Survey of Bell and Harlan Counties, Kentucky. Soil Conservation Service.

USEPA (U.S. Environmental Protection Agency). 2003. Draft Programmatic Environmental Impact Statement. U.S. Army Corps of Engineers, U.S. Environmental Protection Agency, U.S. Fish and Wildlife Service, U.S. Office of Surface Mining, and West Virginia Department of Environmental Protection. Available at: http://www.epa.gov/region3/mtntop/, accessed October 2006. 
Wiley, J.B., Evaldi, R.D., Eychaner, J.H., and Chambers, D.B. 2001. Reconnaissance of Stream Geomorphology, Low Streamflow, and Stream Temperature in the Mountaintop Coal-Mining Region, Southern West Virginia, 1999-2000. WaterResources Investigations Report 01-4092.

Wohl, E.E. 2000. Mountain Rivers. American Geophysical Union: Washington, DC. 
APPENDIX I. PERMIT INFORMATION 
TABLE V

GENERAL PERMITTING INFORMATION

\begin{tabular}{|c|c|c|}
\hline & \multicolumn{2}{|c|}{ Permit No. } \\
\hline & $898-0349$ & $897-0365$ \\
\hline Applicant & Holston Mining, Inc. & $\begin{array}{l}\text { Nally and Hamilton } \\
\text { Enterprises, Inc. }\end{array}$ \\
\hline Original Issue Date ${ }^{1}$ & 2/3/1992 & 12/22/1994 \\
\hline Original Expiration Date ${ }^{2}$ & 9/29/1998 & 12/22/1999 \\
\hline Effective Date $^{3}$ & $6 / 8 / 2000$ & $5 / 28 / 1997$ \\
\hline Latest Inspection Date & $6 / 24 / 2005$ & $8 / 20 / 2002$ \\
\hline Current Site Status ${ }^{4}(8 / 2006)$ & $\begin{array}{c}\text { Permits Completely } \\
\text { Released }\end{array}$ & $\begin{array}{c}\text { Permits Completely } \\
\text { Released }\end{array}$ \\
\hline Contemporaneous Inspection Date ${ }^{5}$ & $2 / 6 / 2002$ & $12 / 12 / 2001$ \\
\hline Date of Aerial Photographs ${ }^{6}$ & $3 / 6 / 2002$ & $2 / 14 / 2002$ \\
\hline Contemporaneous Site Status ${ }^{7}$ & Phase 1 Bond Release & Phase 1 Bond Release \\
\hline Primary Mine Type & Surface & Surface \\
\hline County & Pike & Leslie, Harlan \\
\hline Latitude & $37^{\circ} 33^{\prime} 72^{\prime \prime}$ & $37^{\circ} 01^{\prime} 04^{\prime \prime}$ \\
\hline Longitude & $82^{\circ} 15^{\prime} 70^{\prime \prime}$ & $83^{\circ} 10^{\prime} 16^{\prime \prime}$ \\
\hline Nearest Community & McAndrews, KY & Leatherwood, KY \\
\hline Post-Mining Land Use & $\begin{array}{c}\text { Forest Land/Fish and } \\
\text { Wildlife Habitat }\end{array}$ & $\begin{array}{l}\text { Forest Land/Fish and } \\
\text { Wildlife Habitat }\end{array}$ \\
\hline
\end{tabular}

1. Date on which initial permit application was approved by KYDMP

2. Date on which the original permit expires; 5 years from original issue date; however, permits may be renewed in 5-year increments

3. Date on which the latest revision to the permit was approved; Most recently designed hollow fills are permitted under regulation contemporary with this date.

4. Site status as of latest DMP inspection date; Both sites were with bonds completely released at the time of site investigation of the current study (8/3/2006), indicating observed hollow fills were in their final configuration.

5. Inspection date most recent to, but predating, that of aerial photography

6. Aerial photograph dates were compared to inspection dates to determine contemporary site status; Sites in the phases of bond release or with bonds completely released were assumed to have completely constructed hollow fills

7. Site status contemporary with aerial photography; As-built longitudinal profile generated for the current study represent Hollow Fills that have been completed, but not fully released from bonding. 


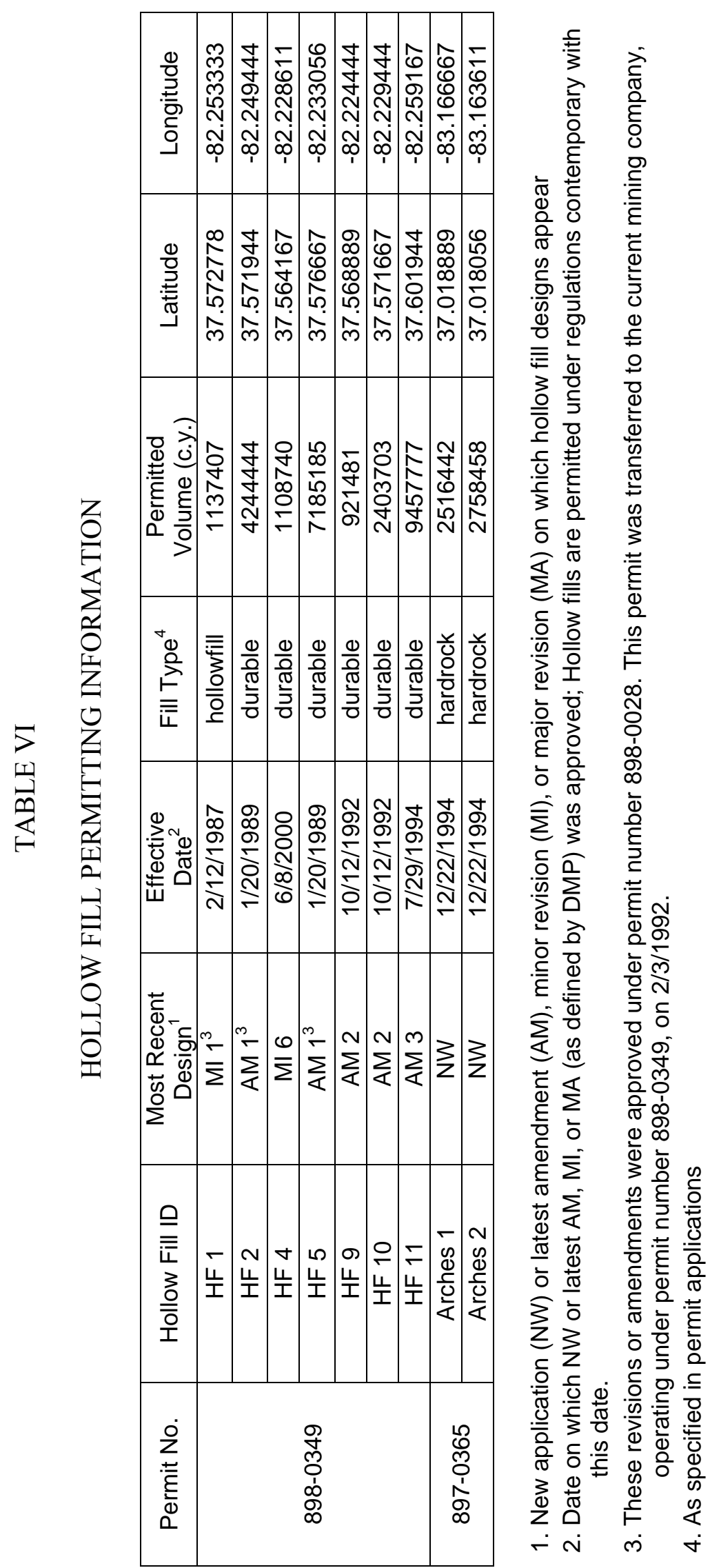




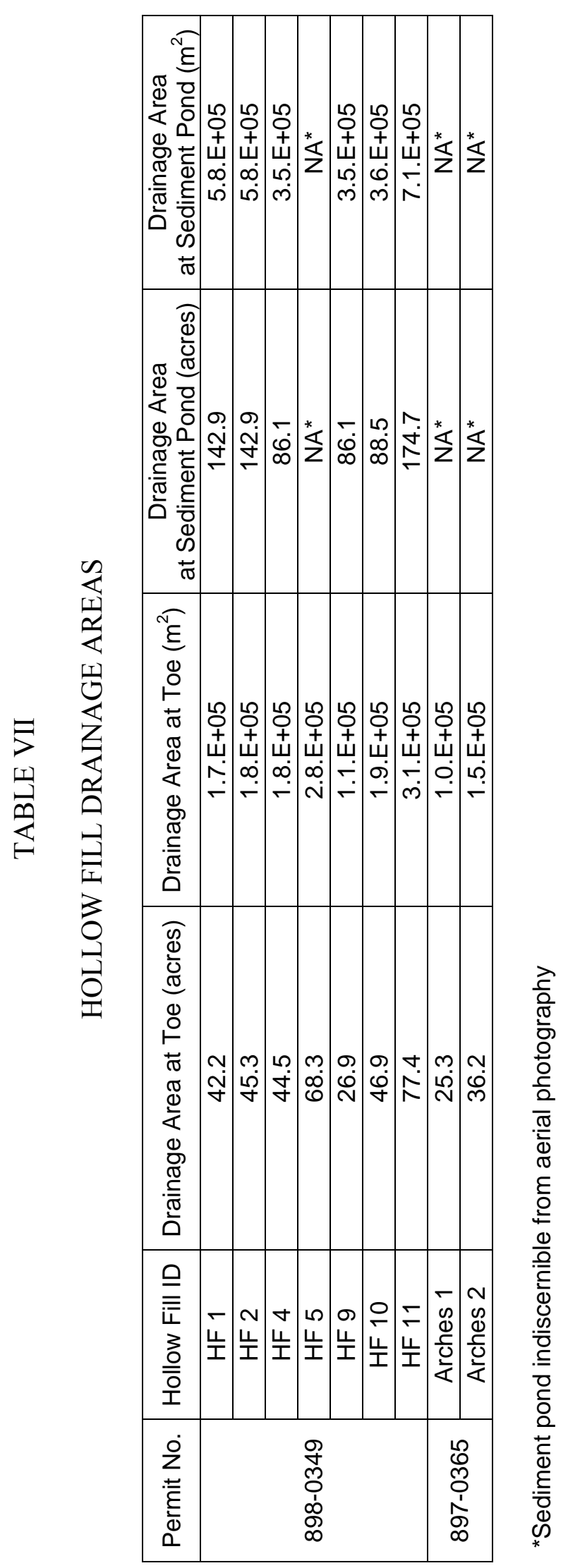


APPENDIX II. AERIAL PHOTOGRAPHY 


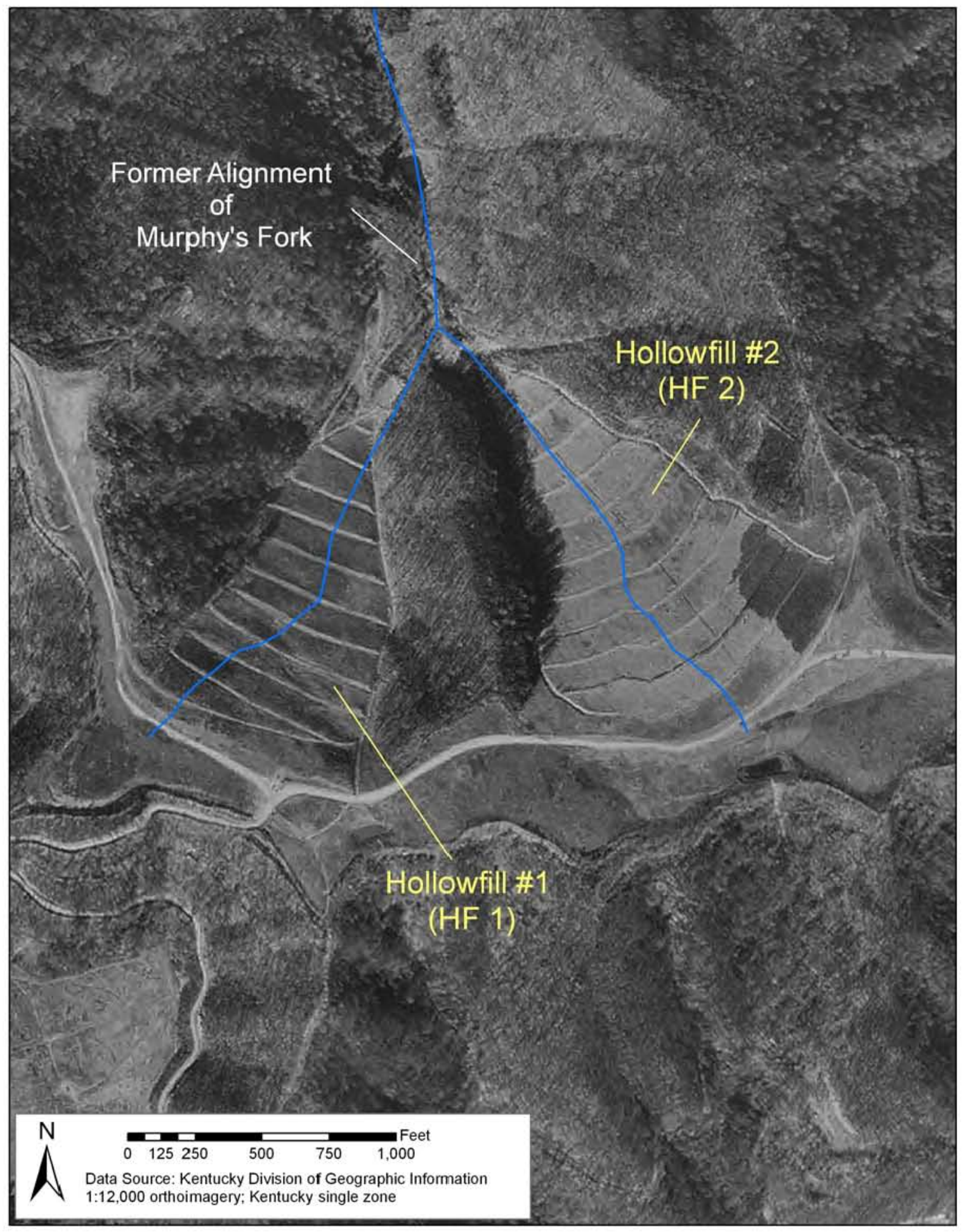

FIGURE 54 - Aerial Photograph of HF 1 and HF 2 (Permit No. 898-0349) 


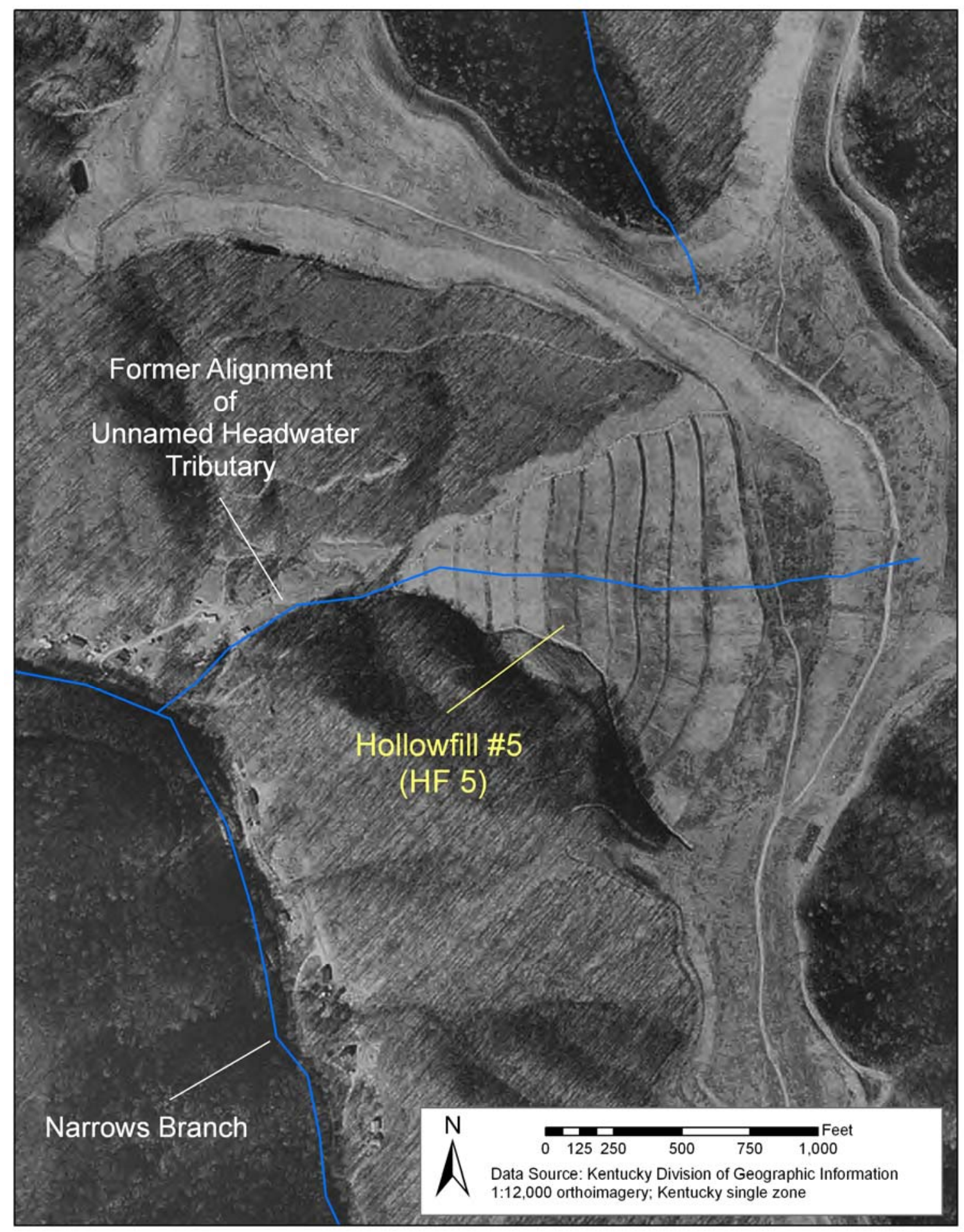

FIGURE 55 - Aerial Photograph of HF 5 (Permit No. 898-0349) 


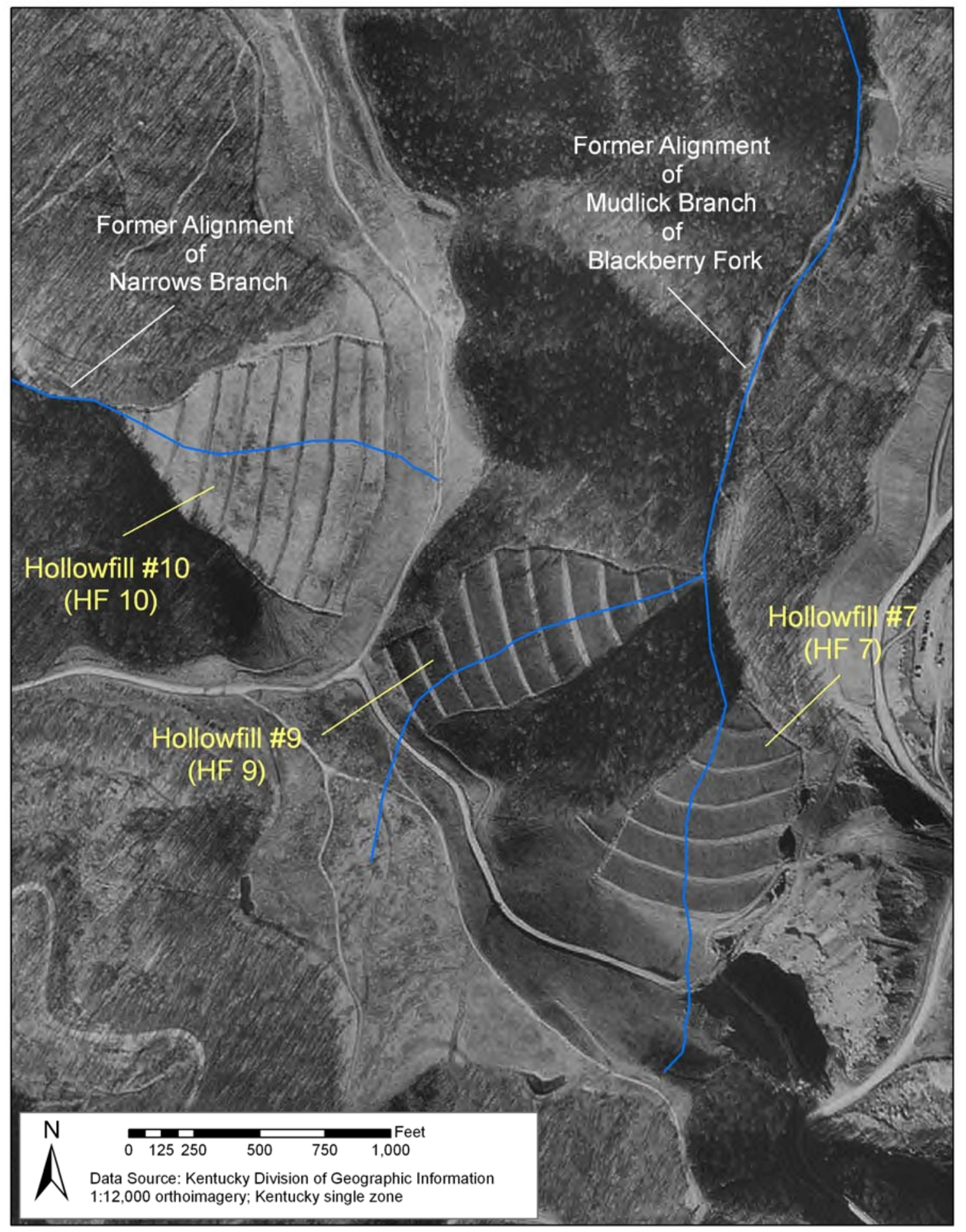

FIGURE 56 - Aerial Photograph of HF 4, 9, and 10 (Permit No. 898-0349) 


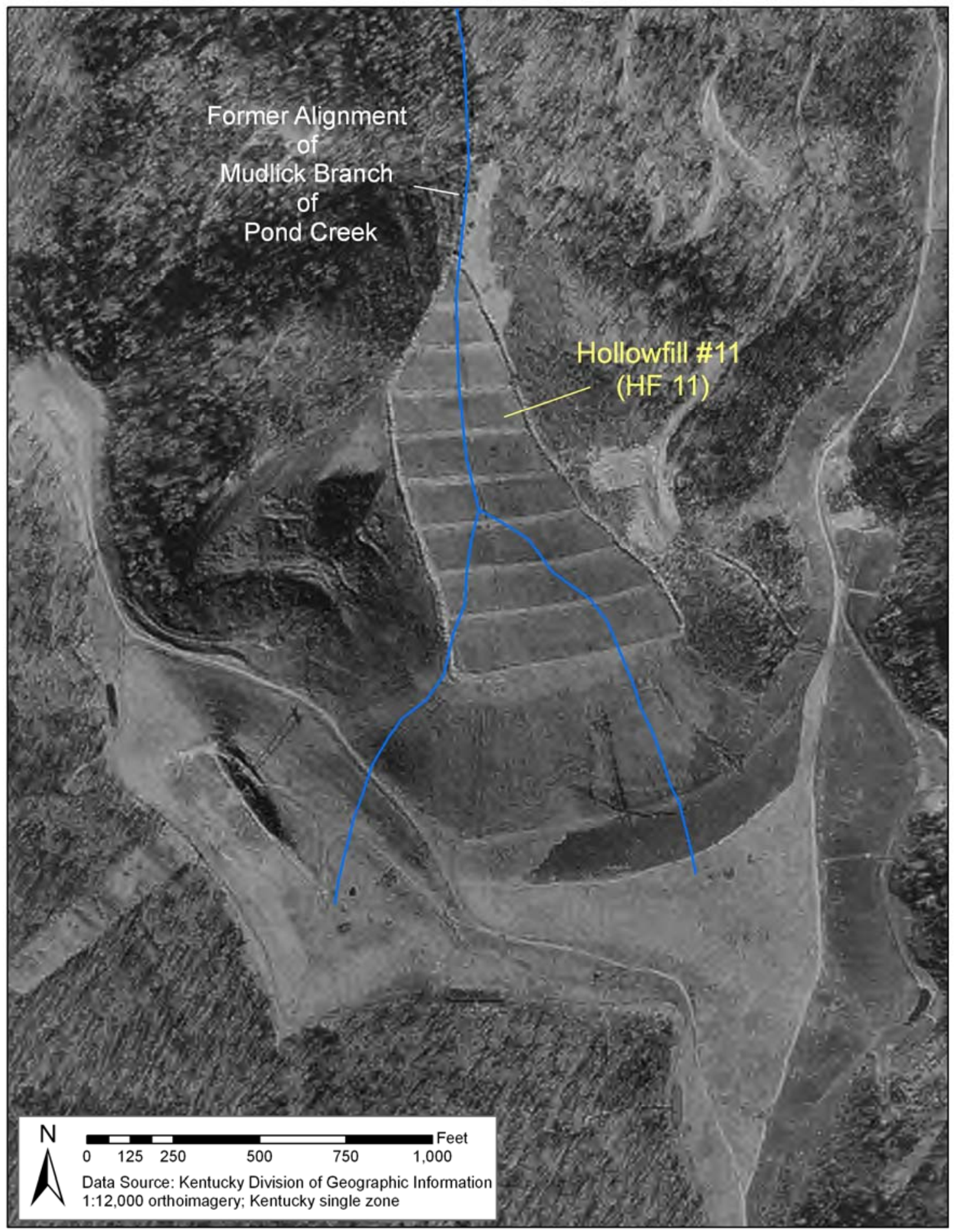

FIGURE 57 - Aerial Photograph of HF 11 


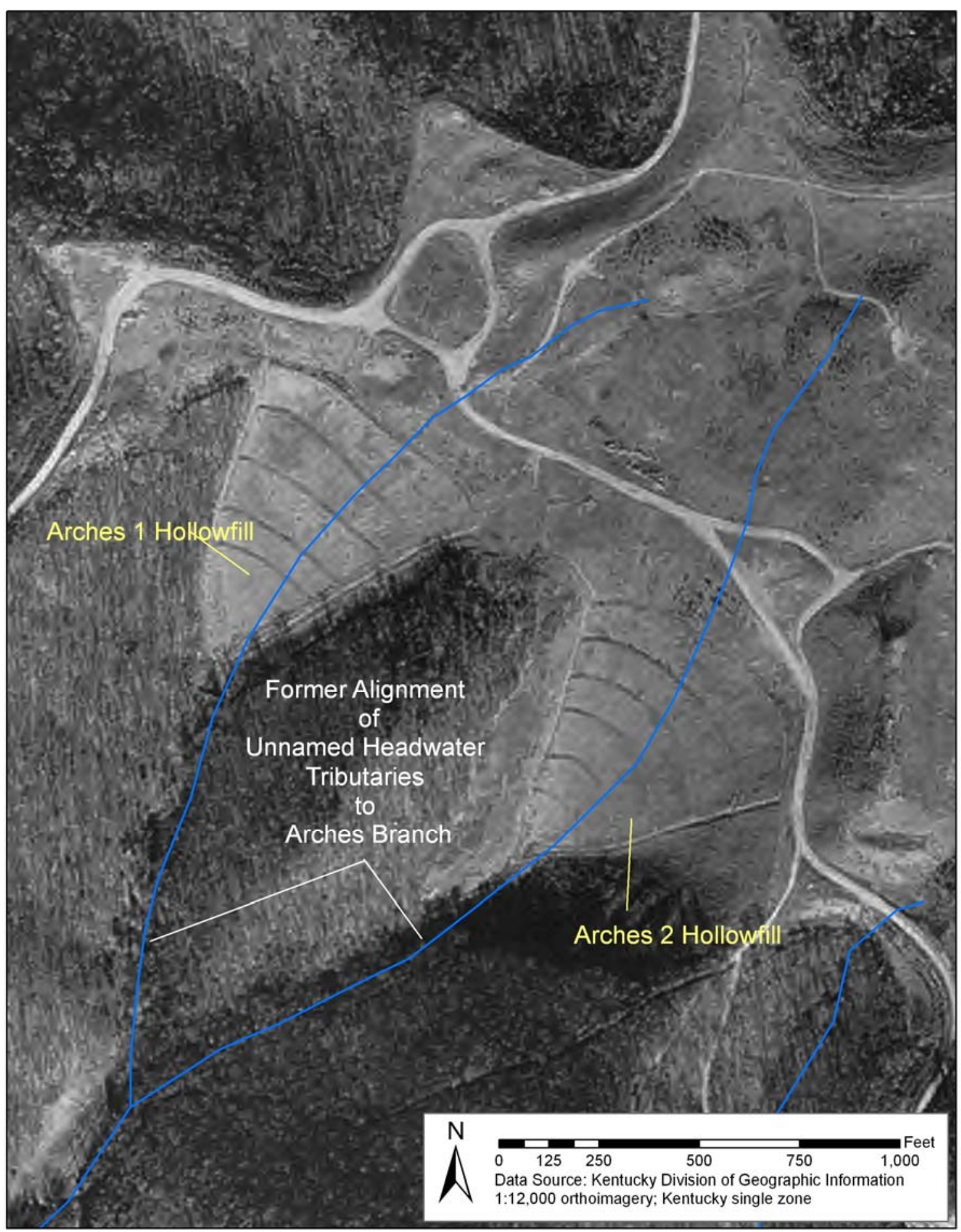

FIGURE 58 - Aerial Photograph of Arches 1 and Arches 2 (Permit No. 897-0365) 
APPENDIX III. HOLLOW FILL PLAN OVERLAYS 


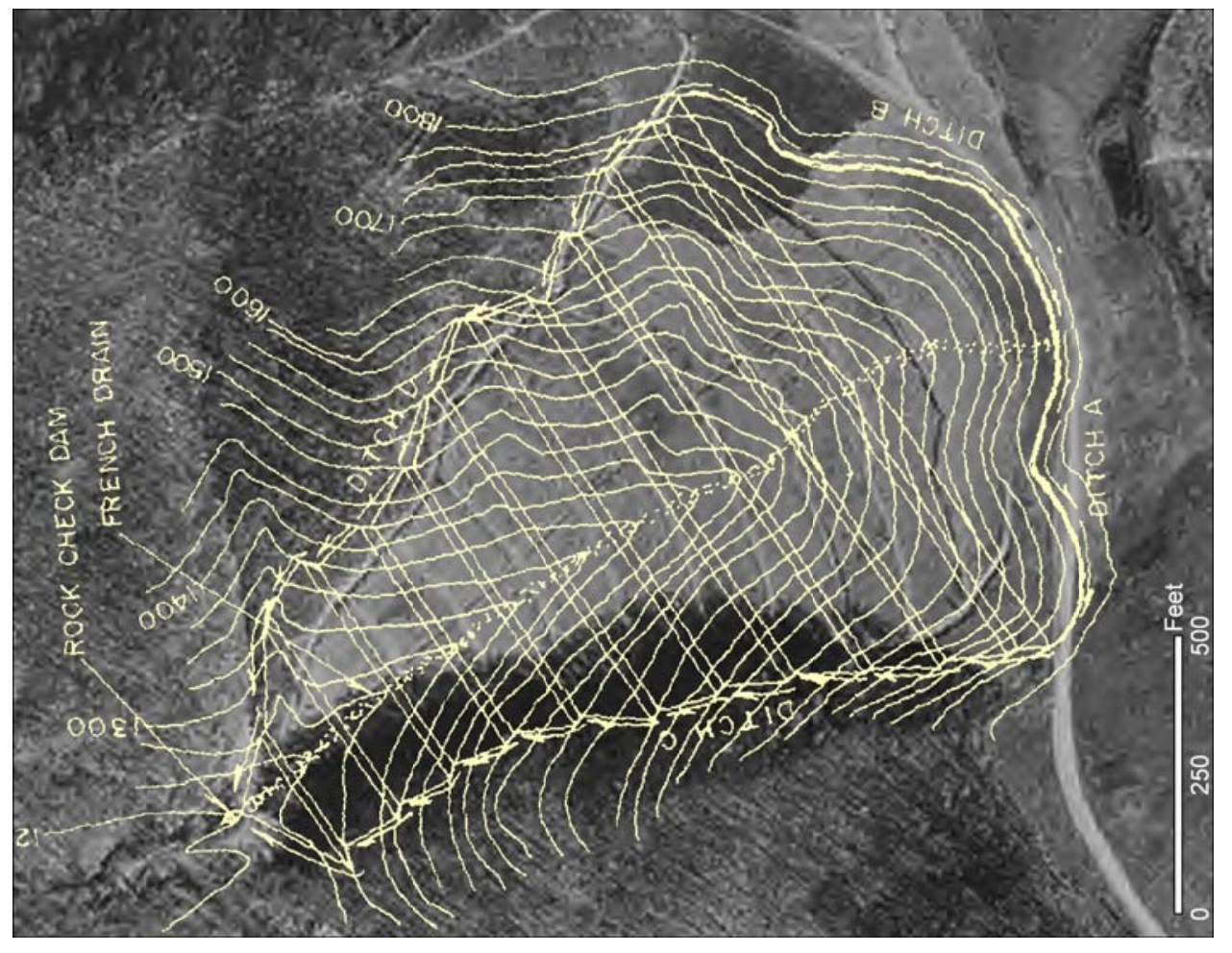

a

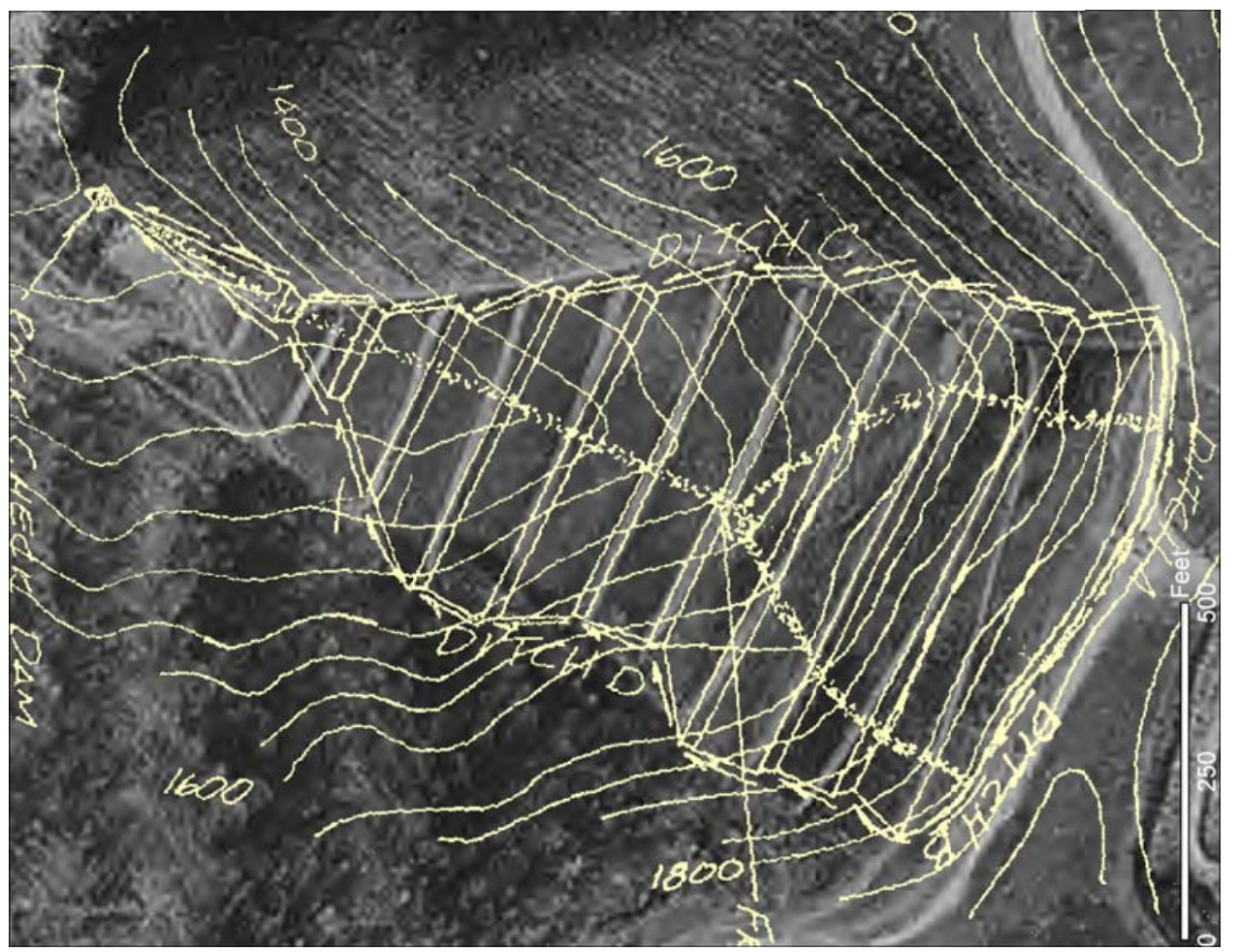

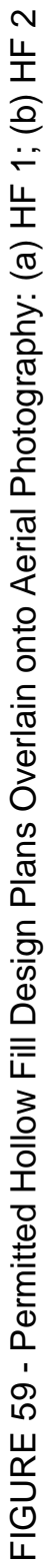

(ర) 


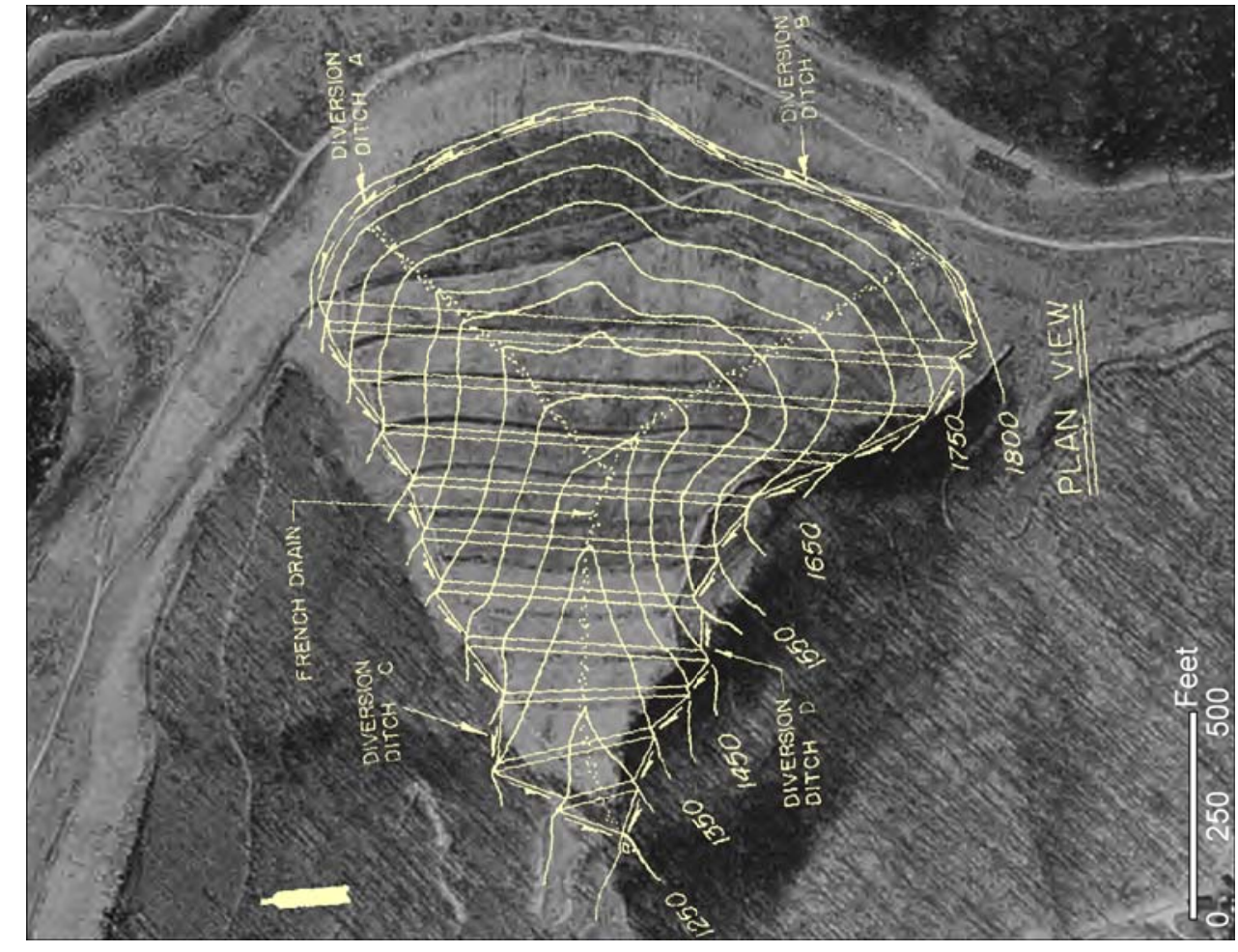

a

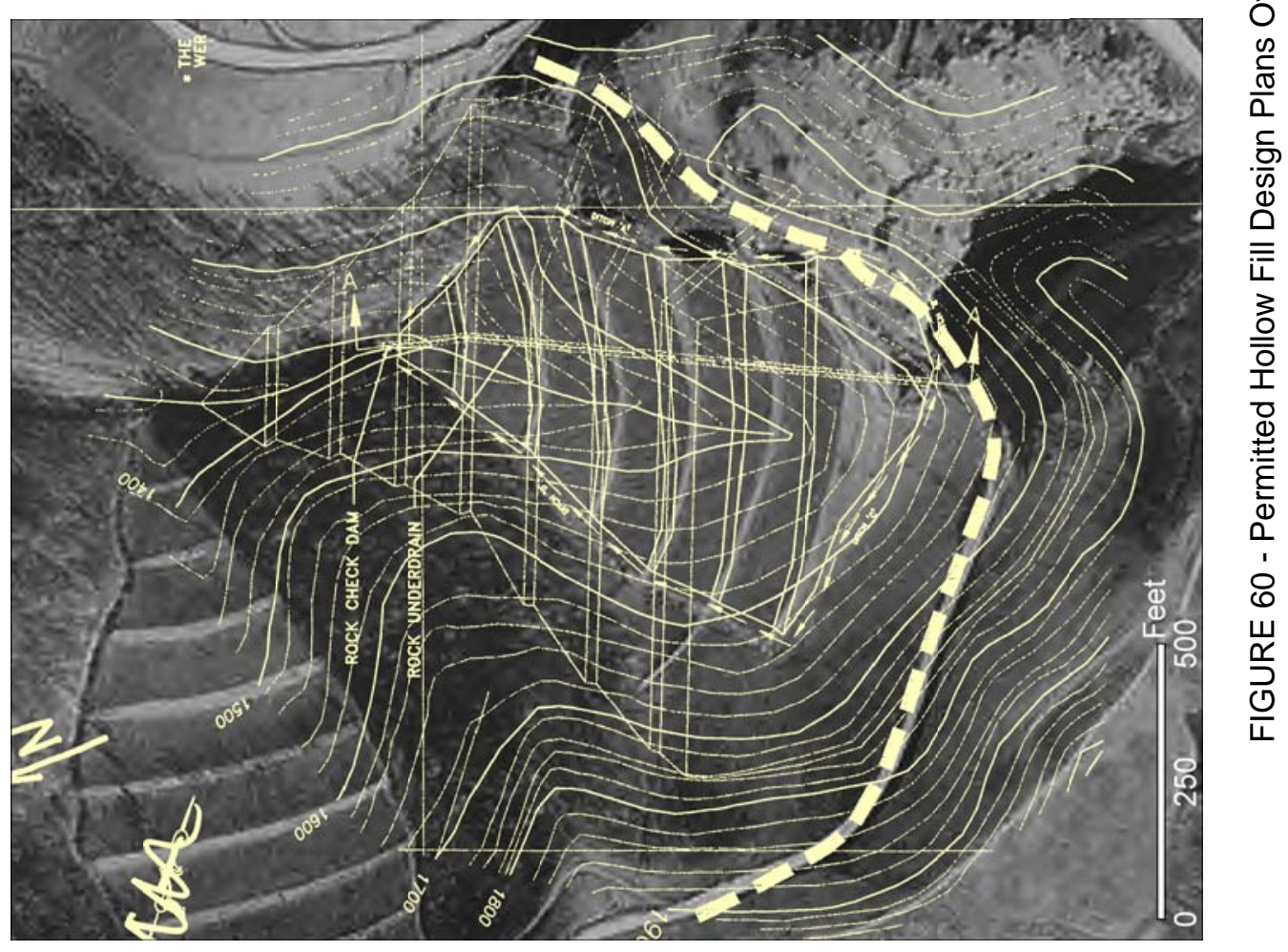

๔ 


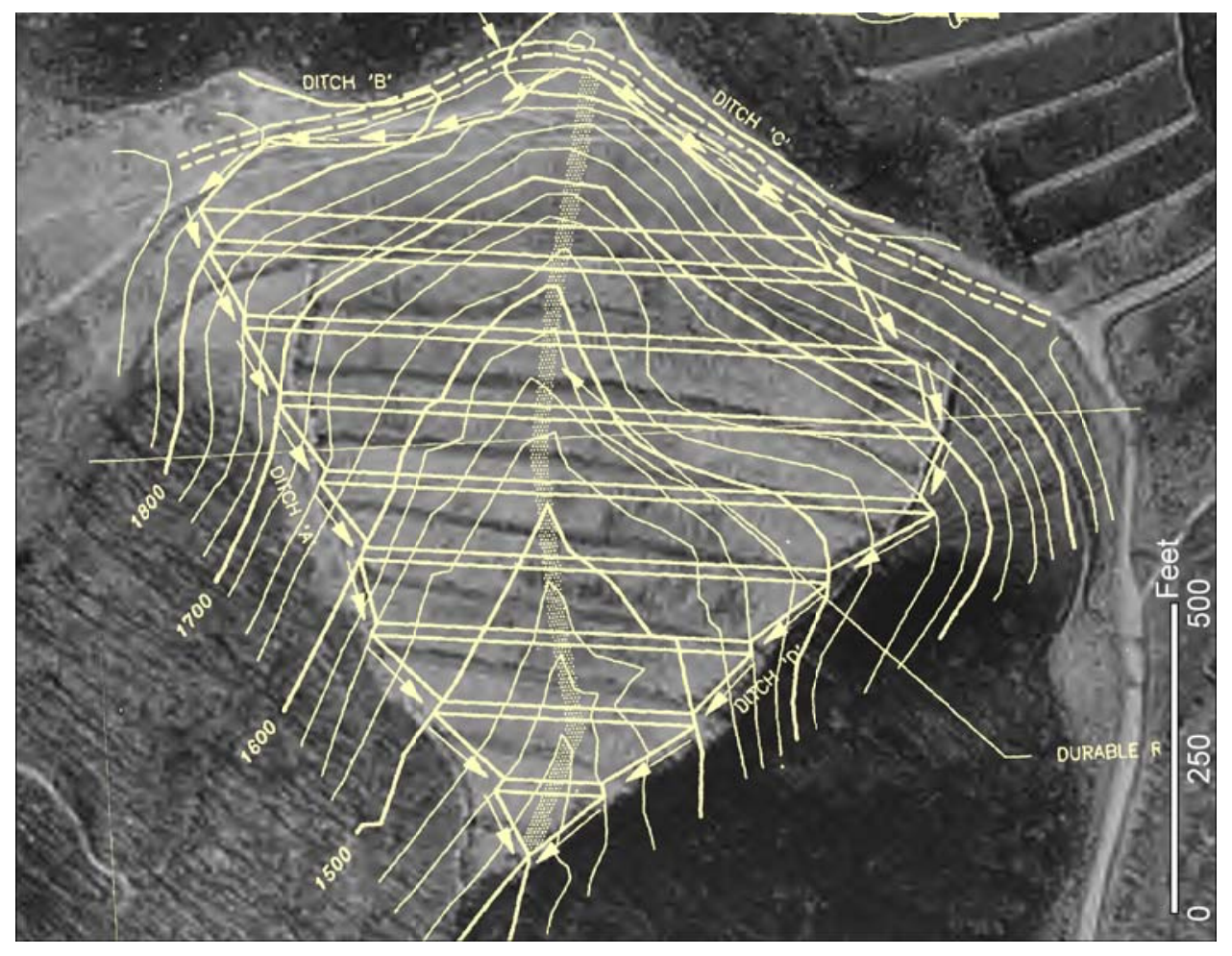

a

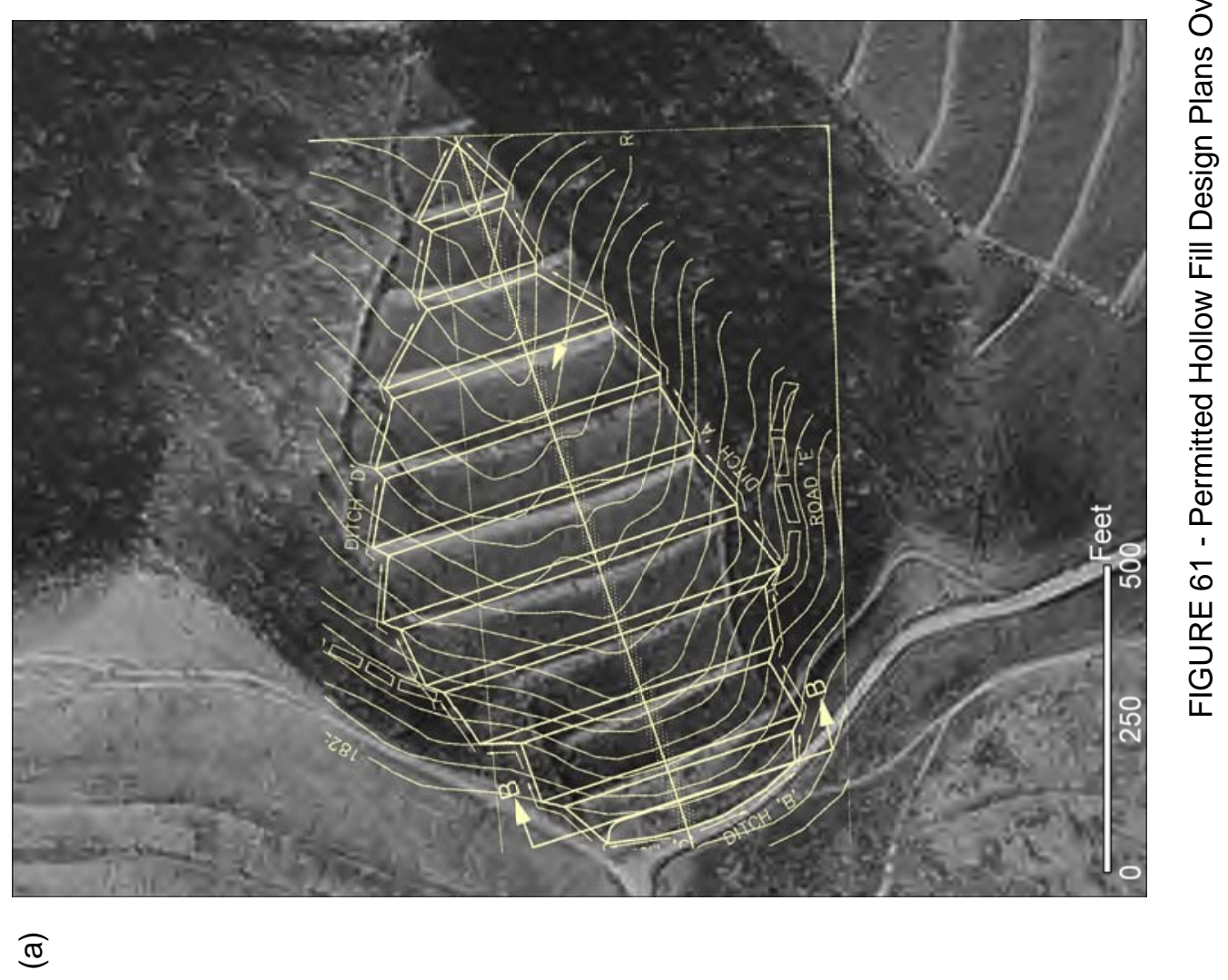




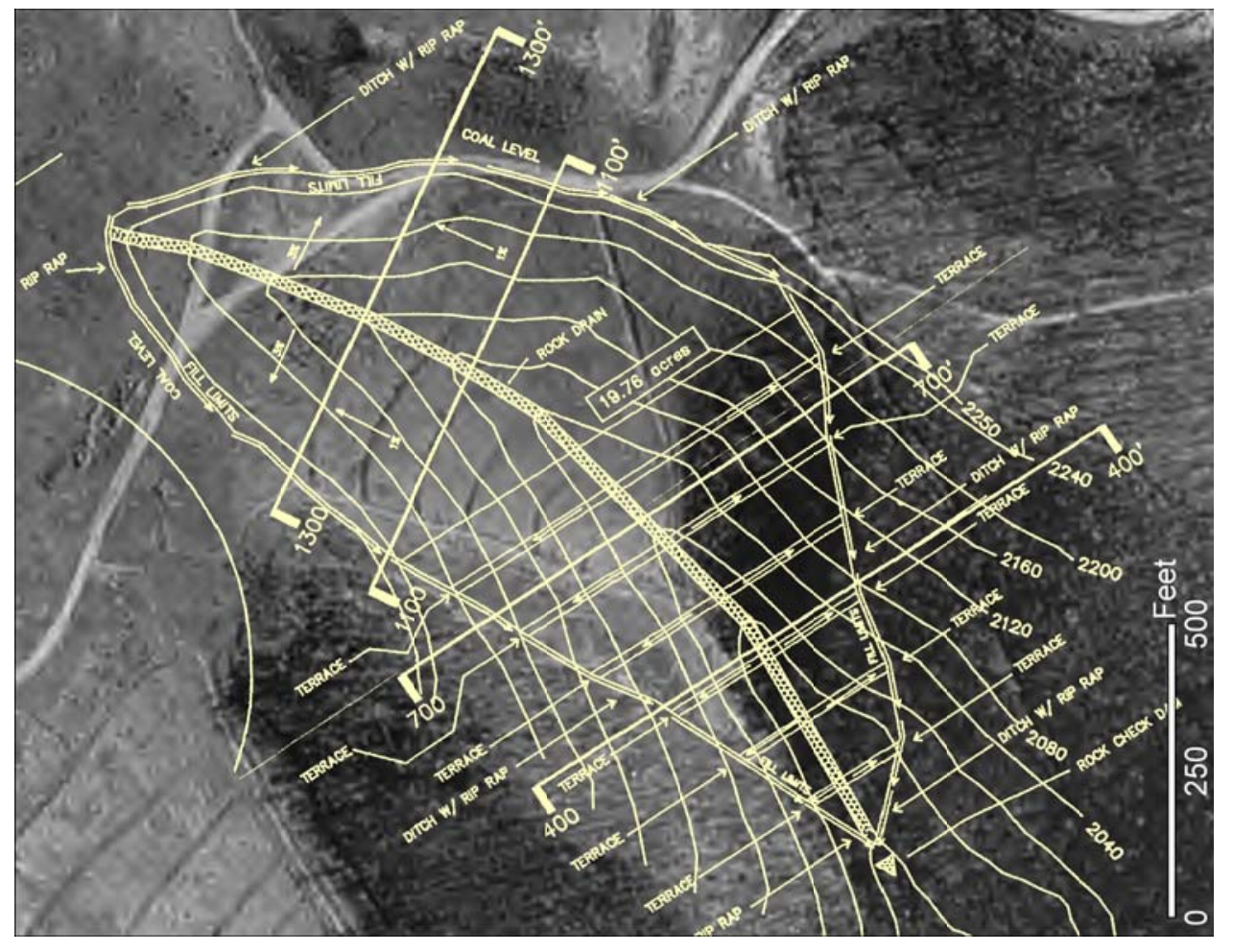

a

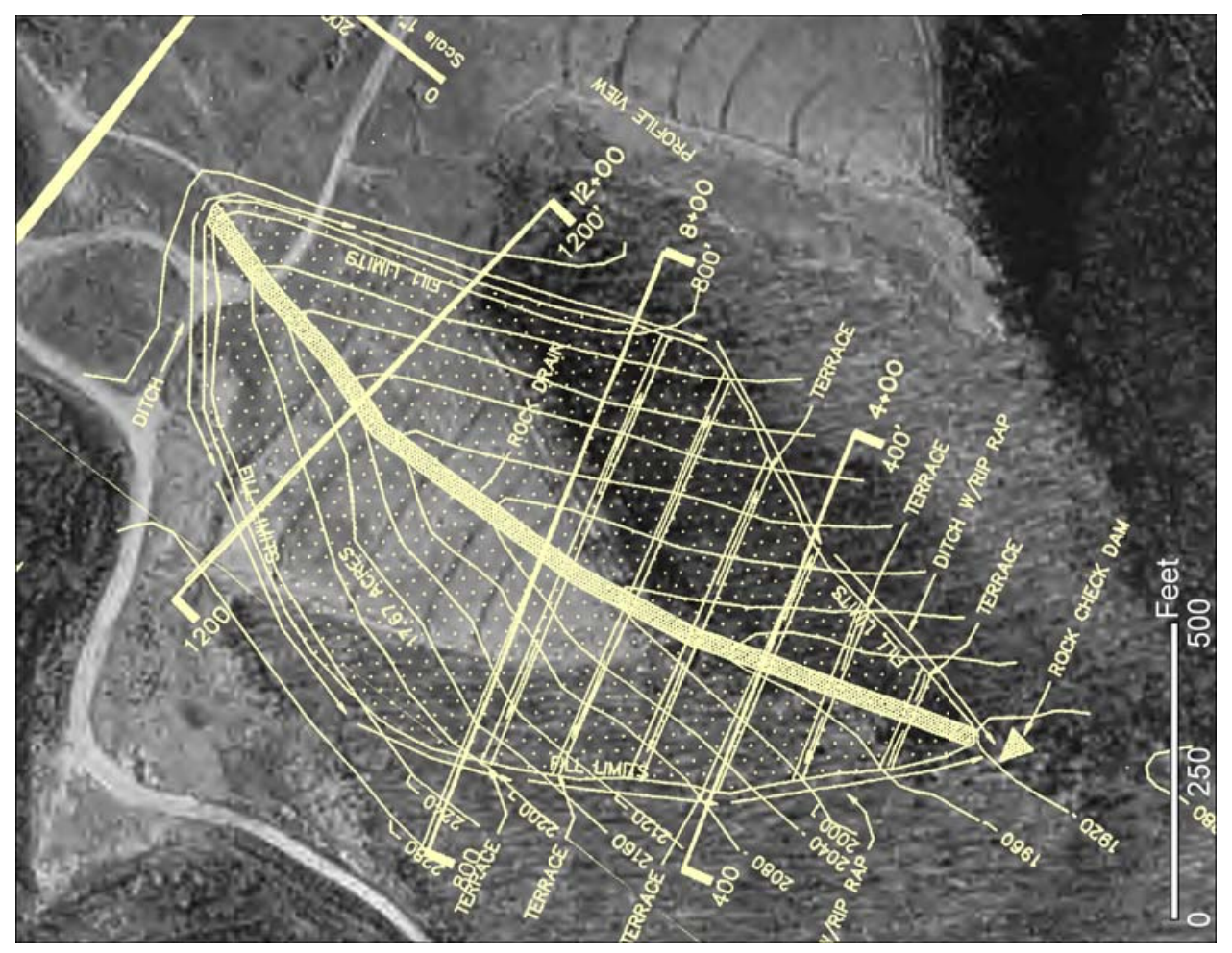

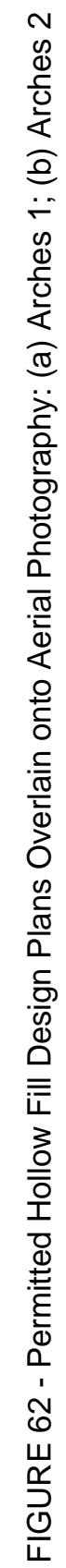

త్ర 
APPENDIX IV. LONGITUDINAL PROFILES 


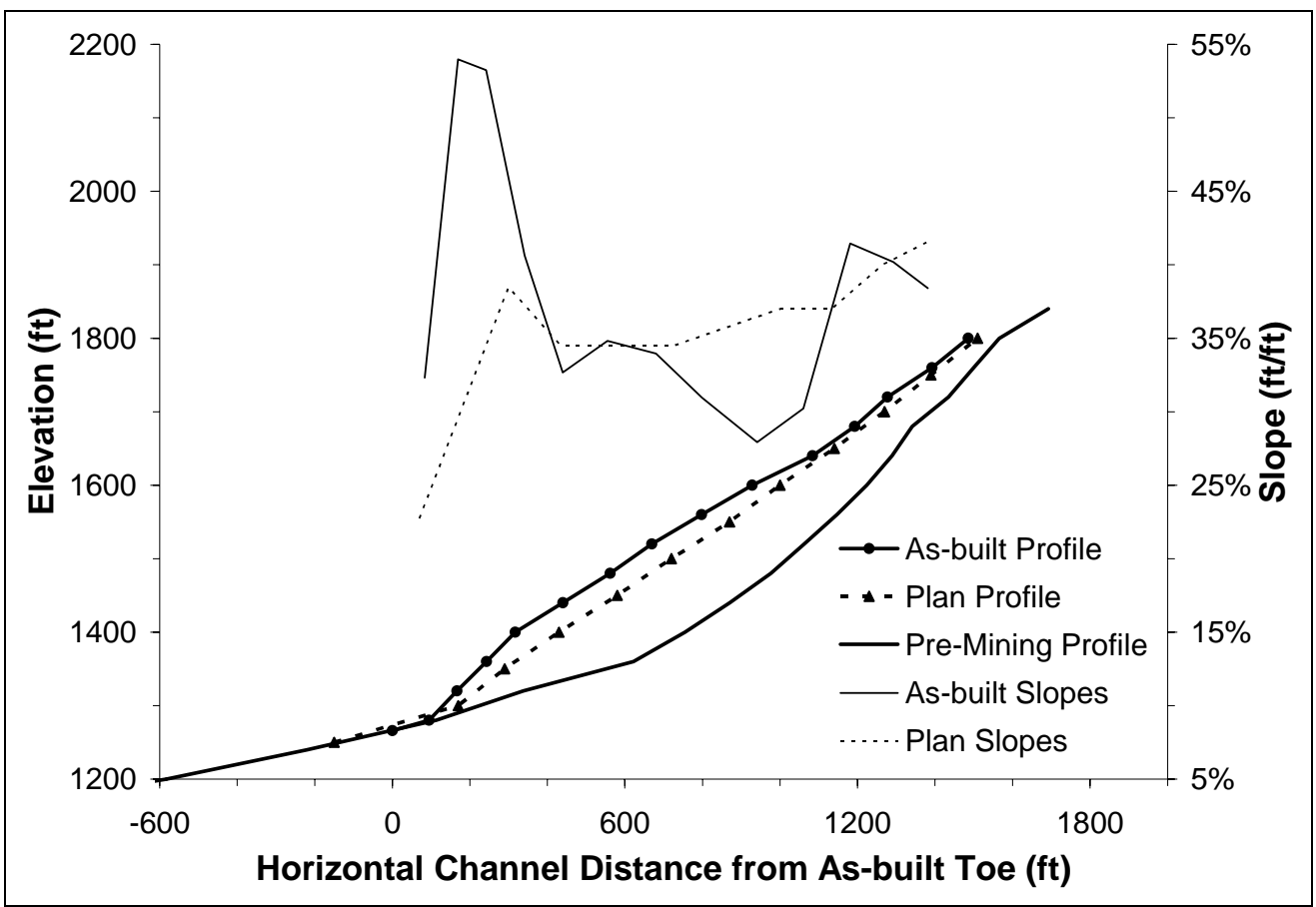

FIGURE 63 - Comparison of Plan and As-Built Longitudinal Groin Ditch Profiles for the East Groin Ditch of HF 1

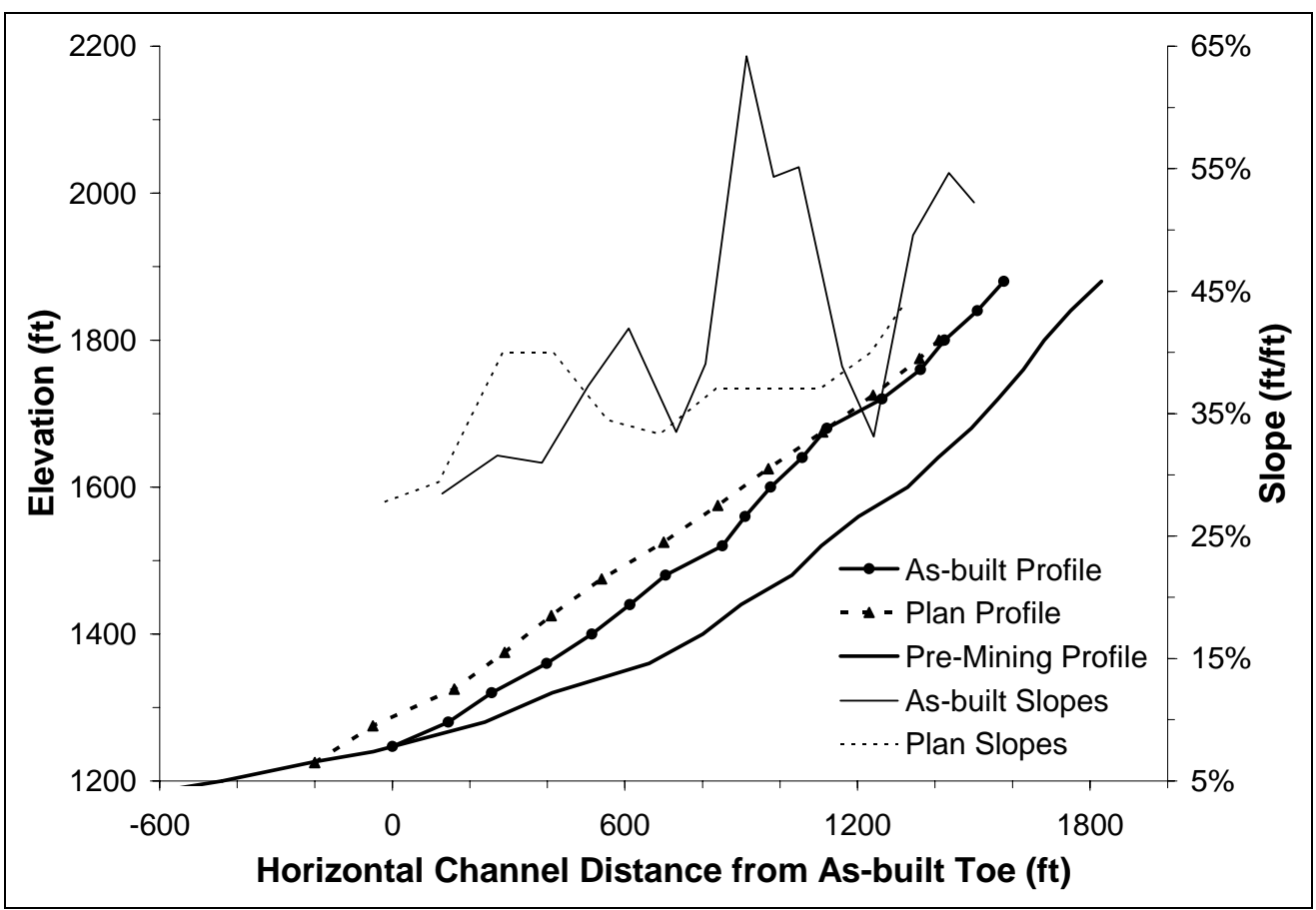

FIGURE 64 - Comparison of Plan and As-Built Longitudinal Groin Ditch Profiles for the East Groin Ditch of HF 2 


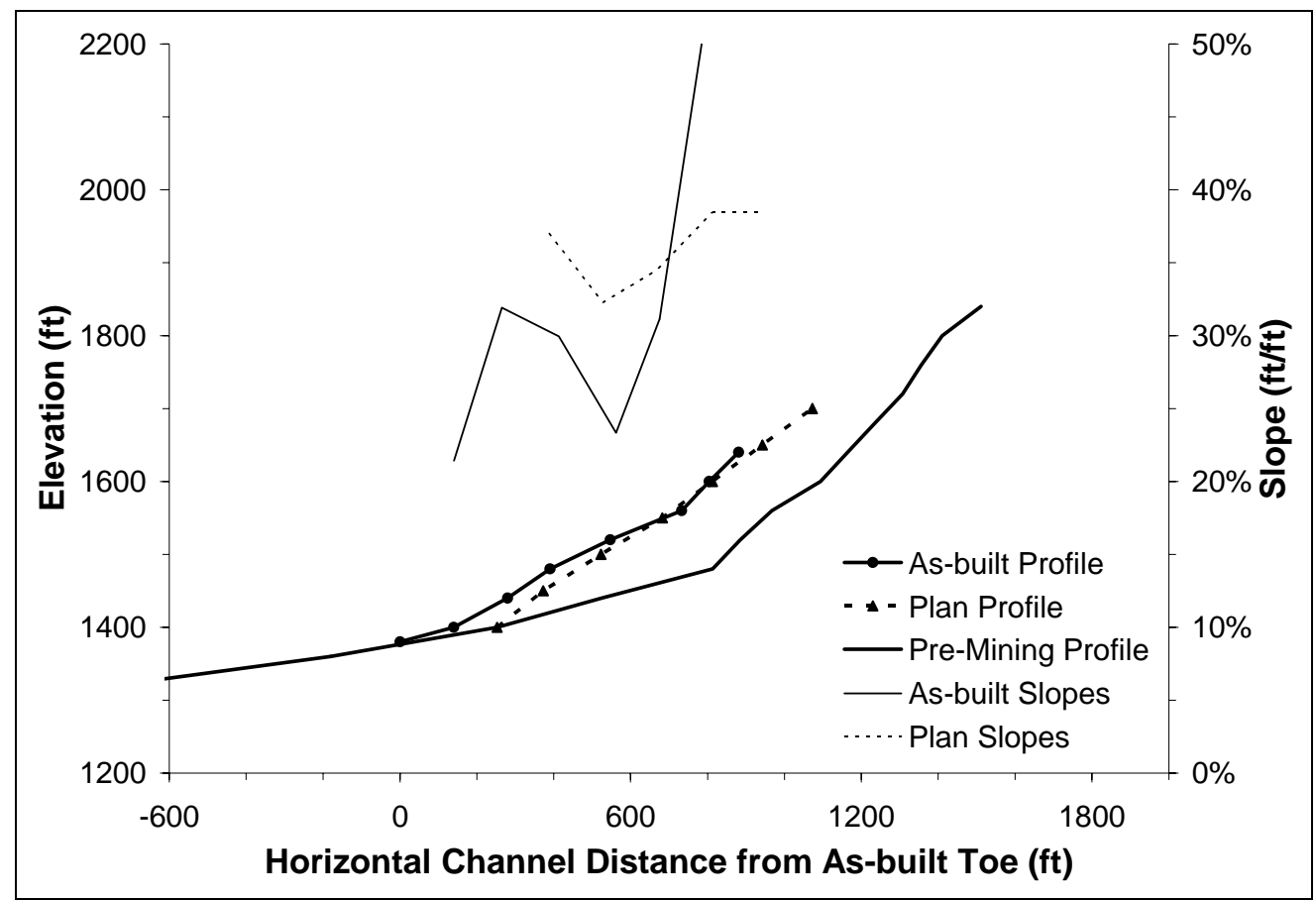

FIGURE 65 - Comparison of Plan and As-Built Longitudinal Groin Ditch Profiles for the West Groin Ditch of HF 4 
(a)

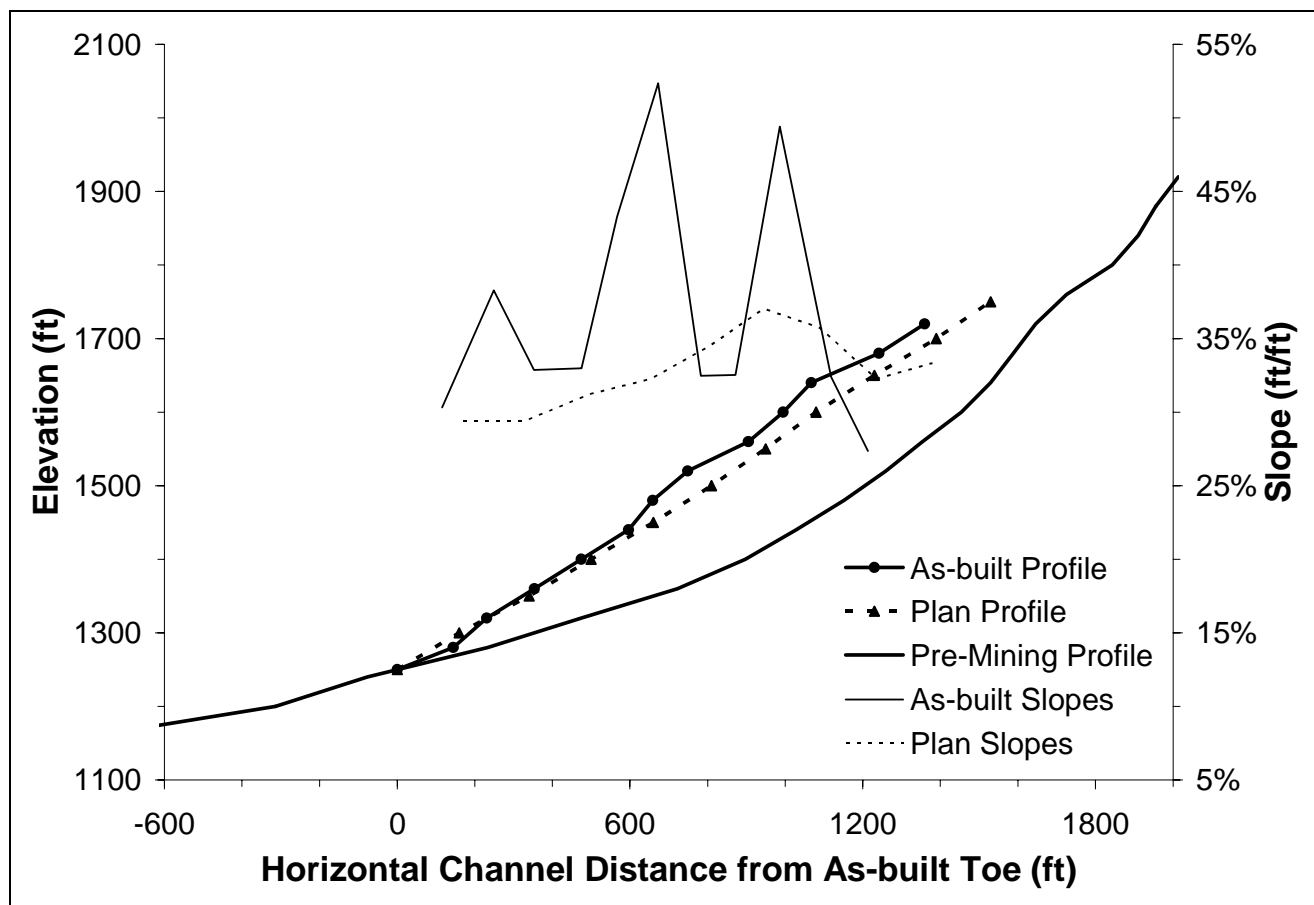

(b)

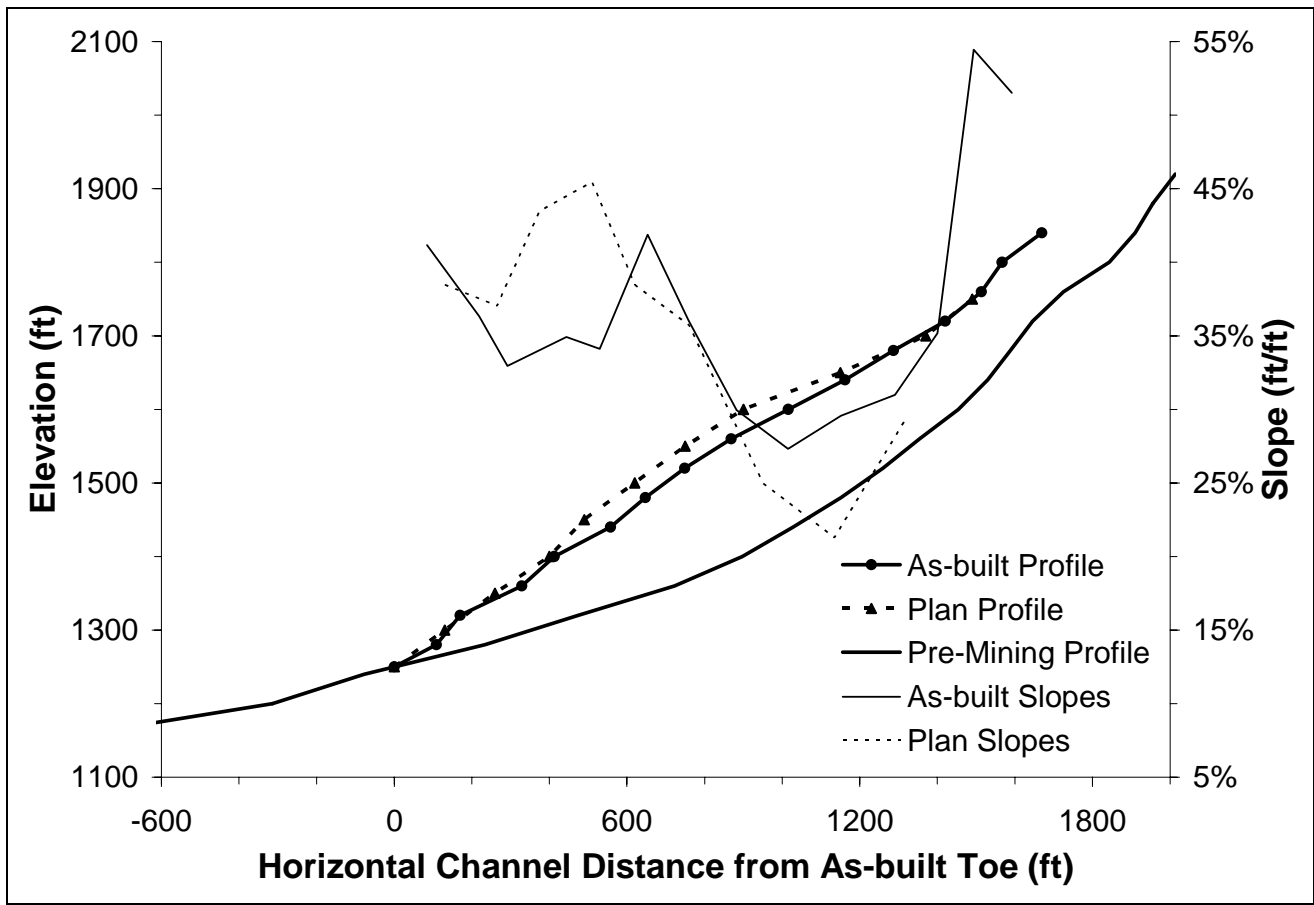

FIGURE 66 - Comparison of Plan and As-Built Longitudinal Groin Ditch Profiles for (a) North and (b) South Groin Ditches of HF 5 
(a)

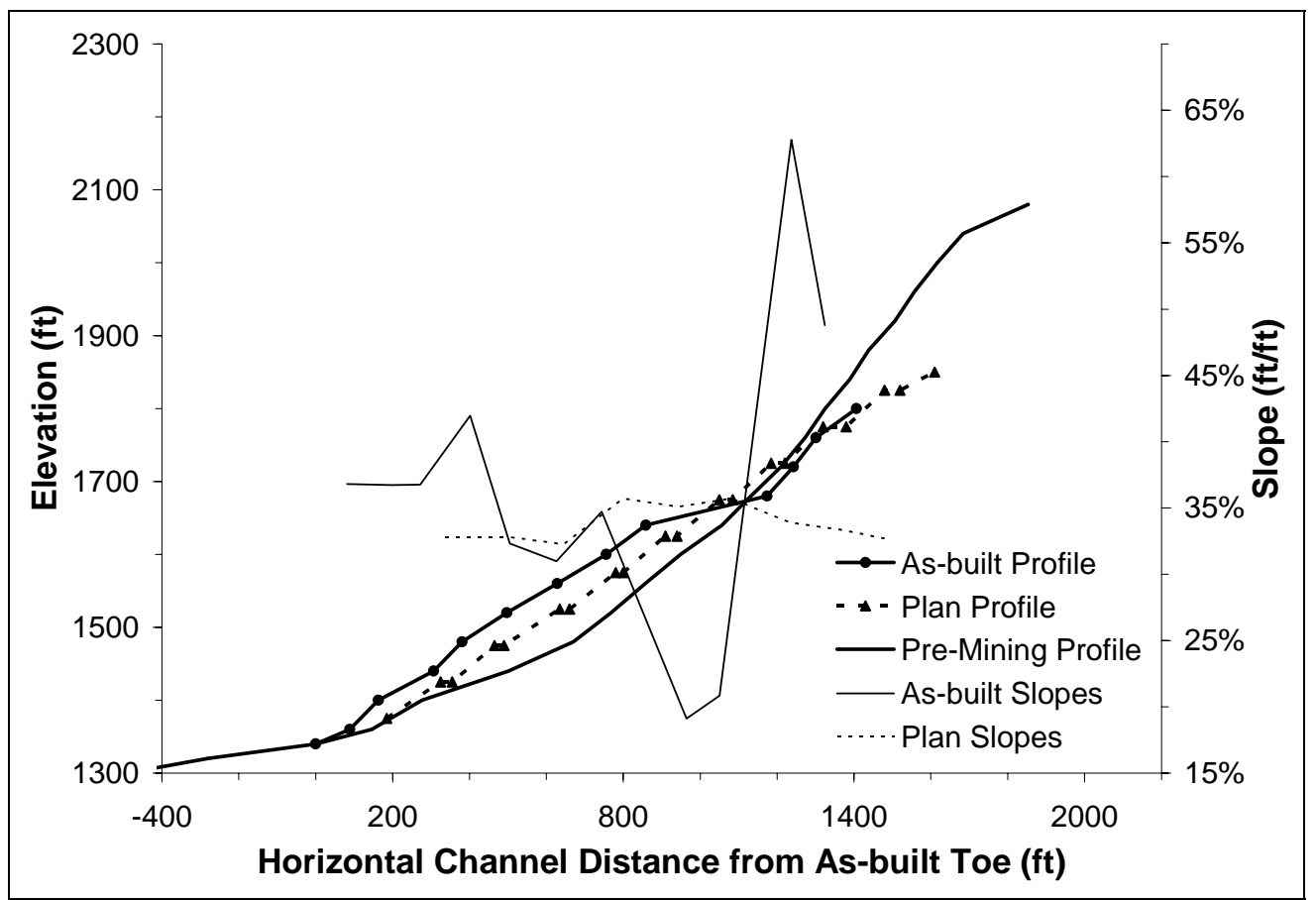

(b)

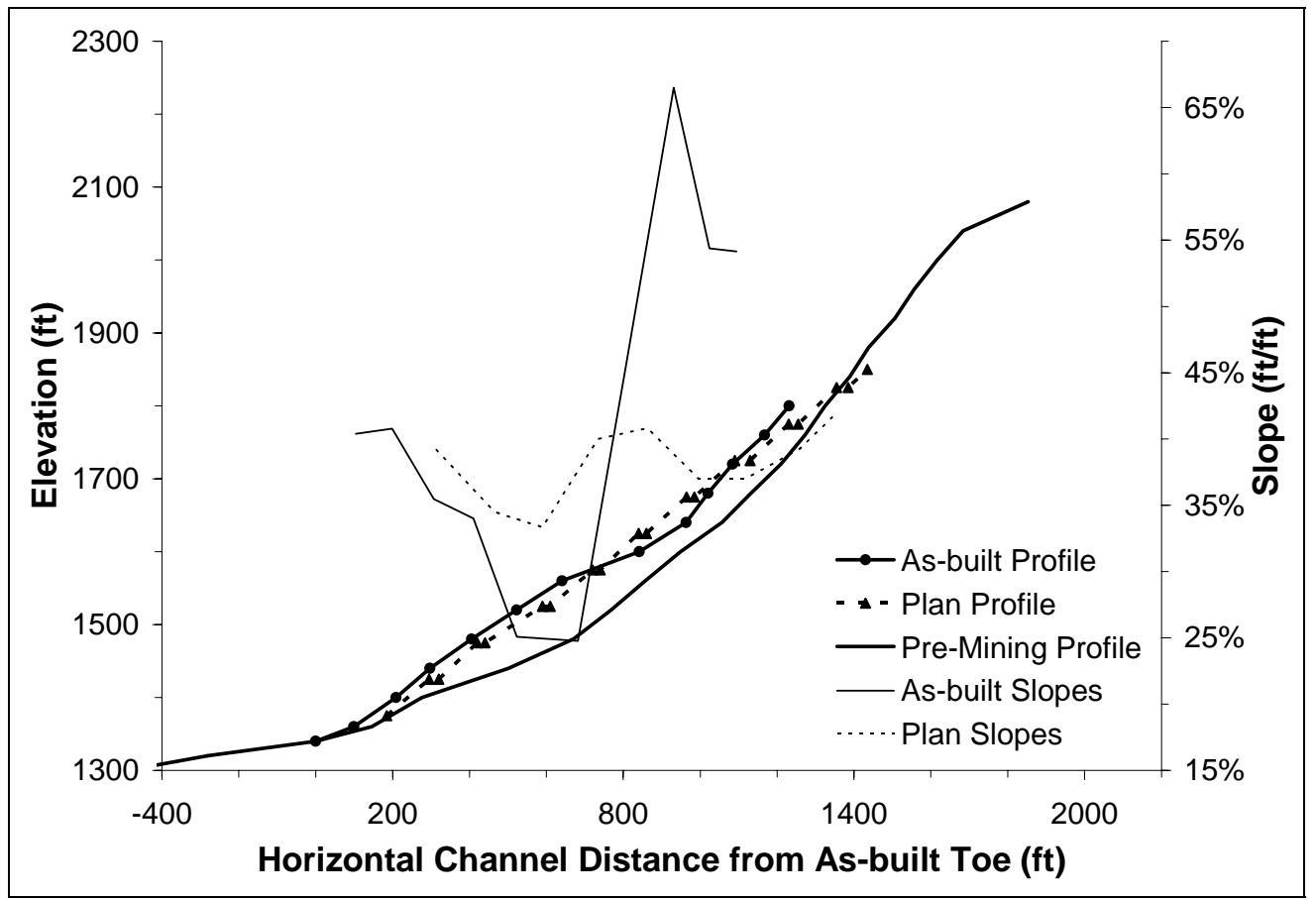

FIGURE 67 - Comparison of Plan and As-Built Longitudinal Groin Ditch Profiles for (a) North and (b) South Groin Ditches of HF 9 
(a)

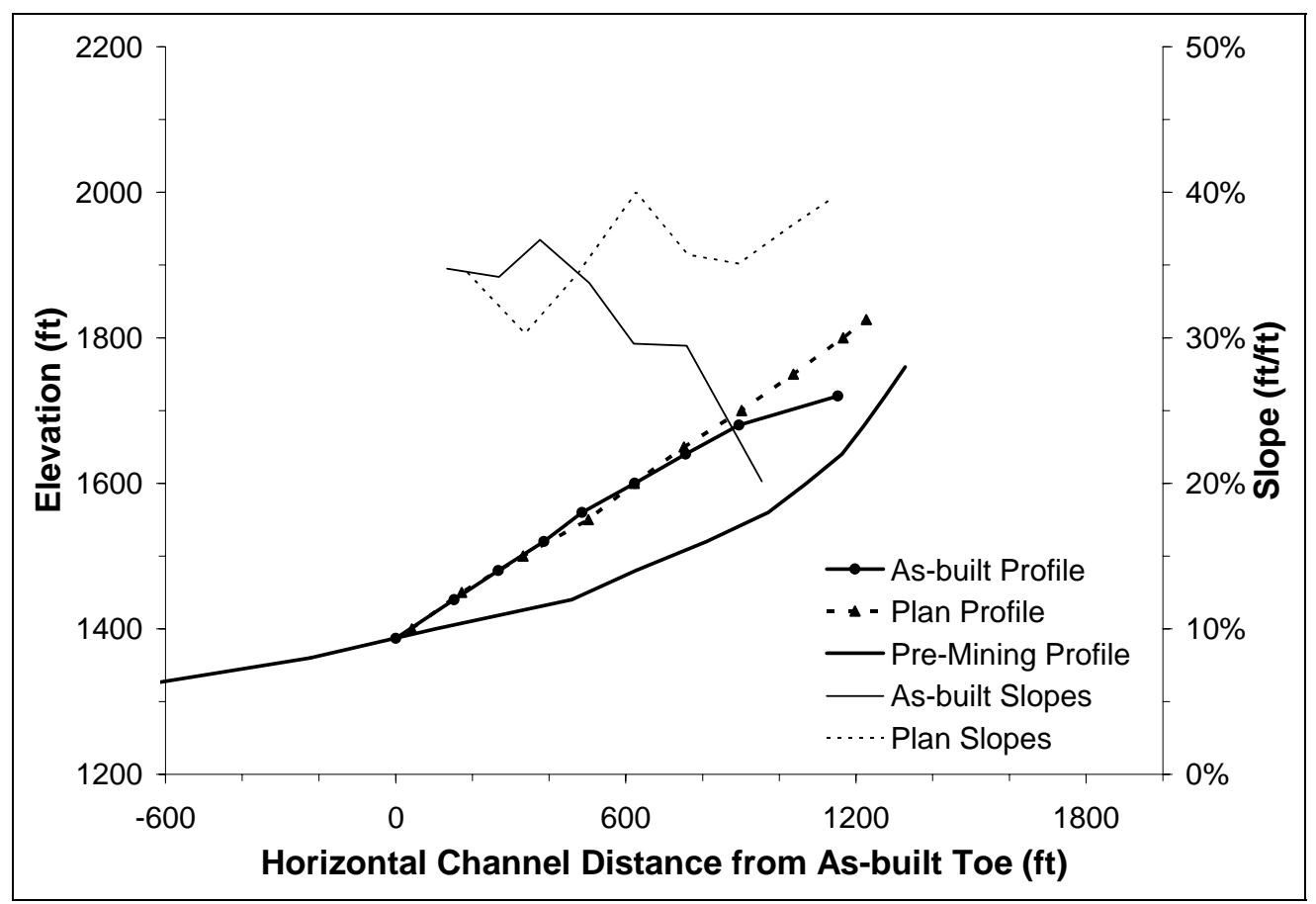

(b)

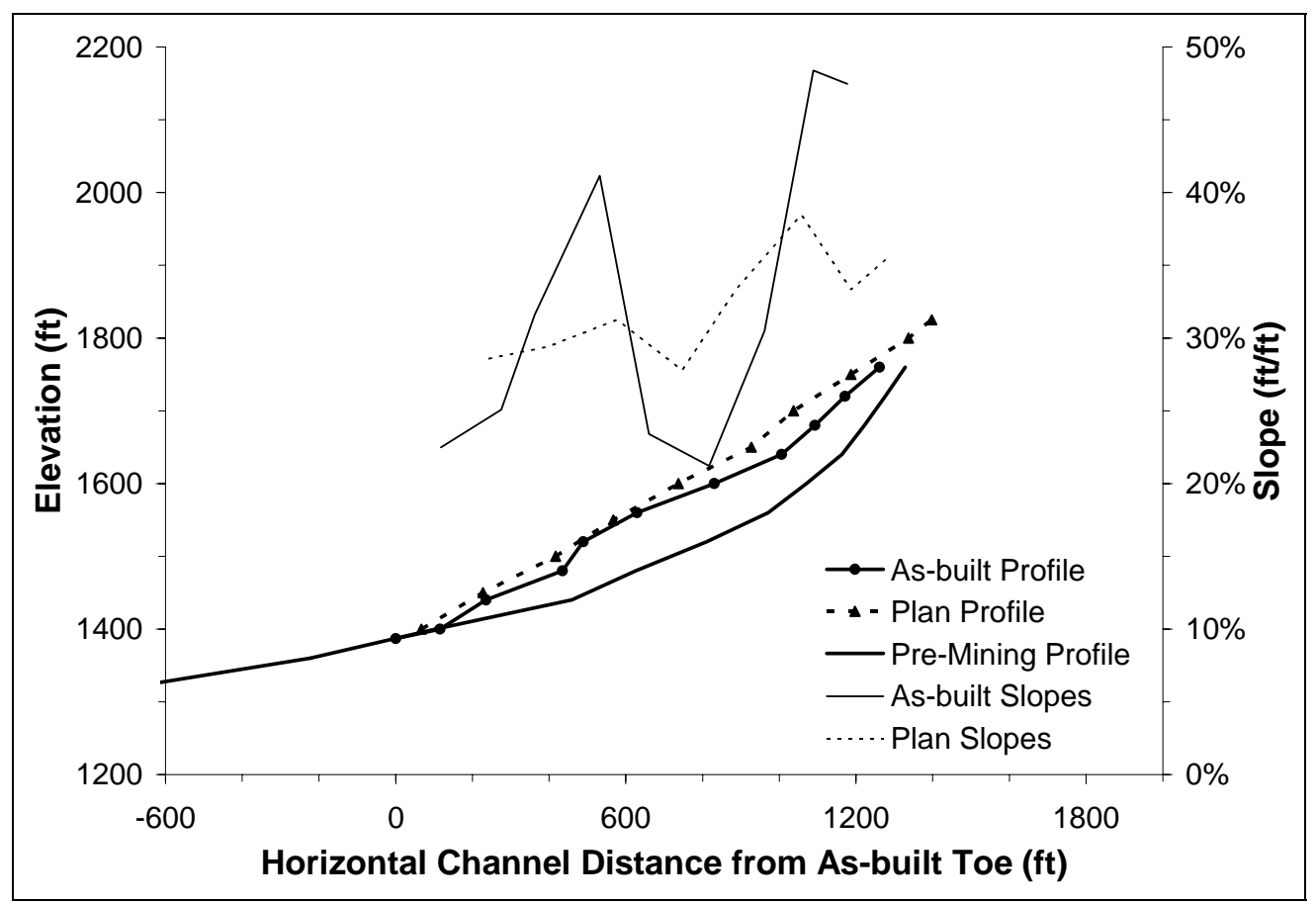

FIGURE 68 - Comparison of Plan and As-Built Longitudinal Groin Ditch Profiles for (a) North and (b) South Groin Ditches of HF 10 
(a)

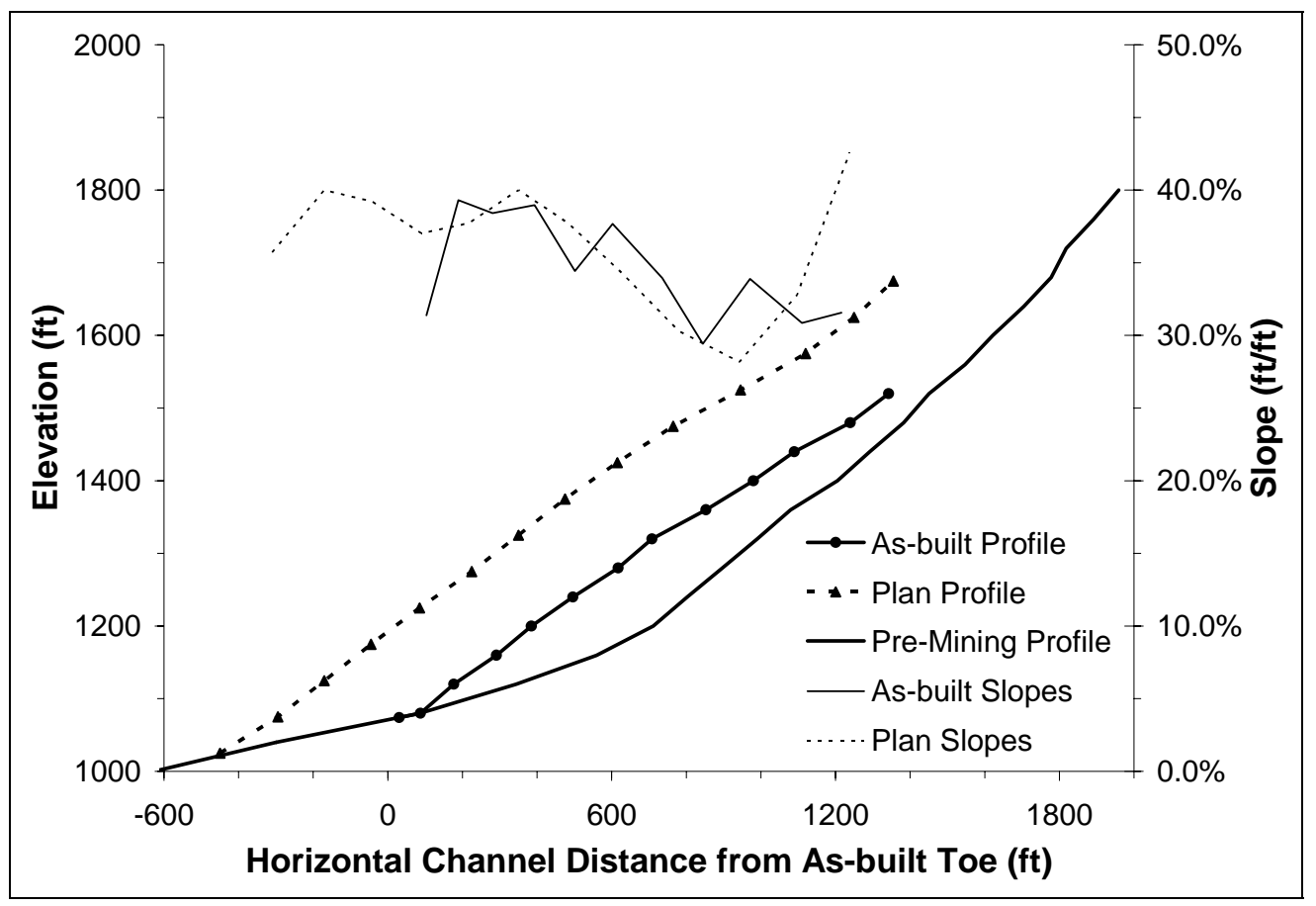

(b)

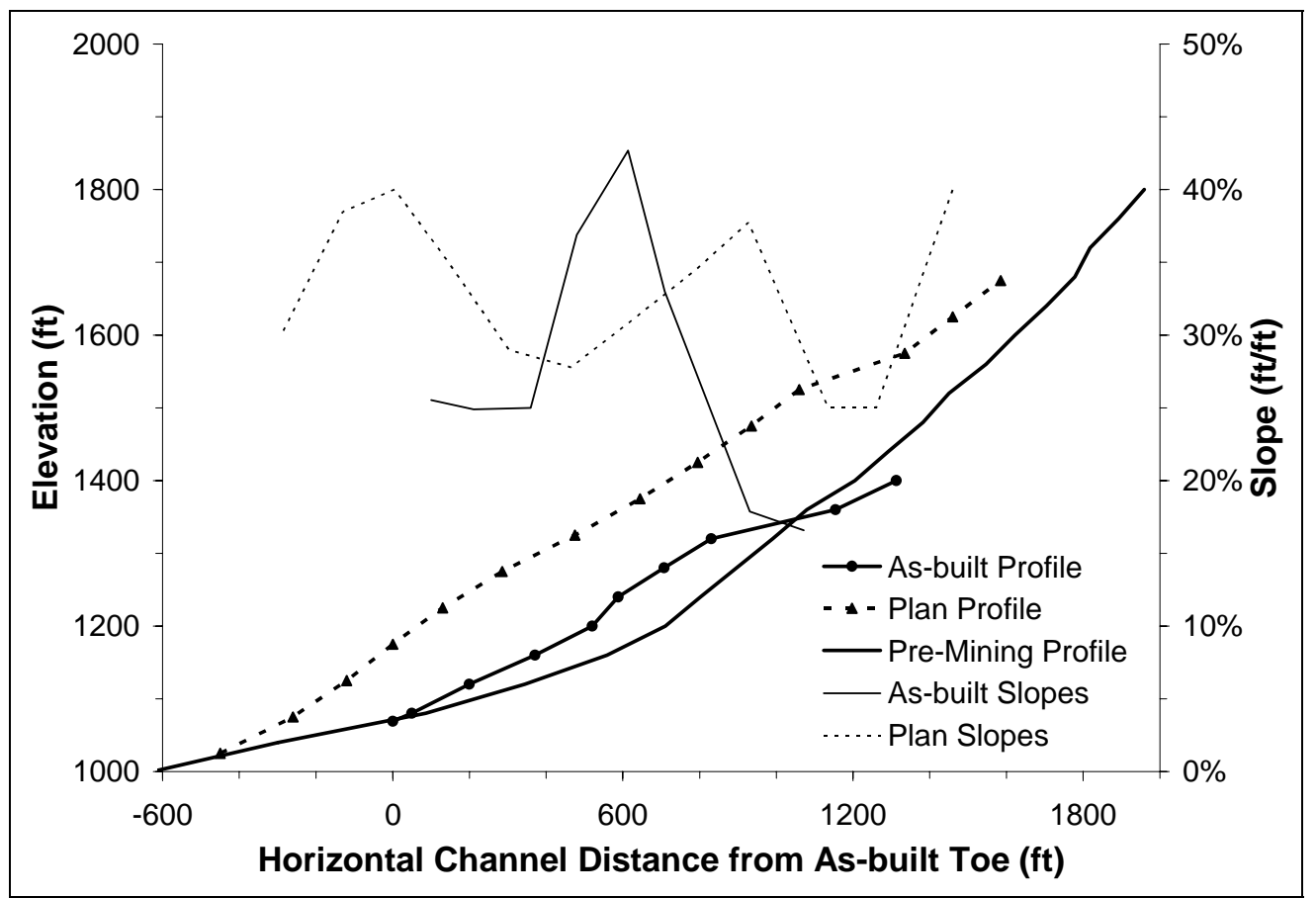

FIGURE 69 - Comparison of Plan and As-Built Groin Ditch and Pre-Mining Stream Longitudinal Profiles for (a) East and (b) West Groin Ditches of HF 11 
(a)

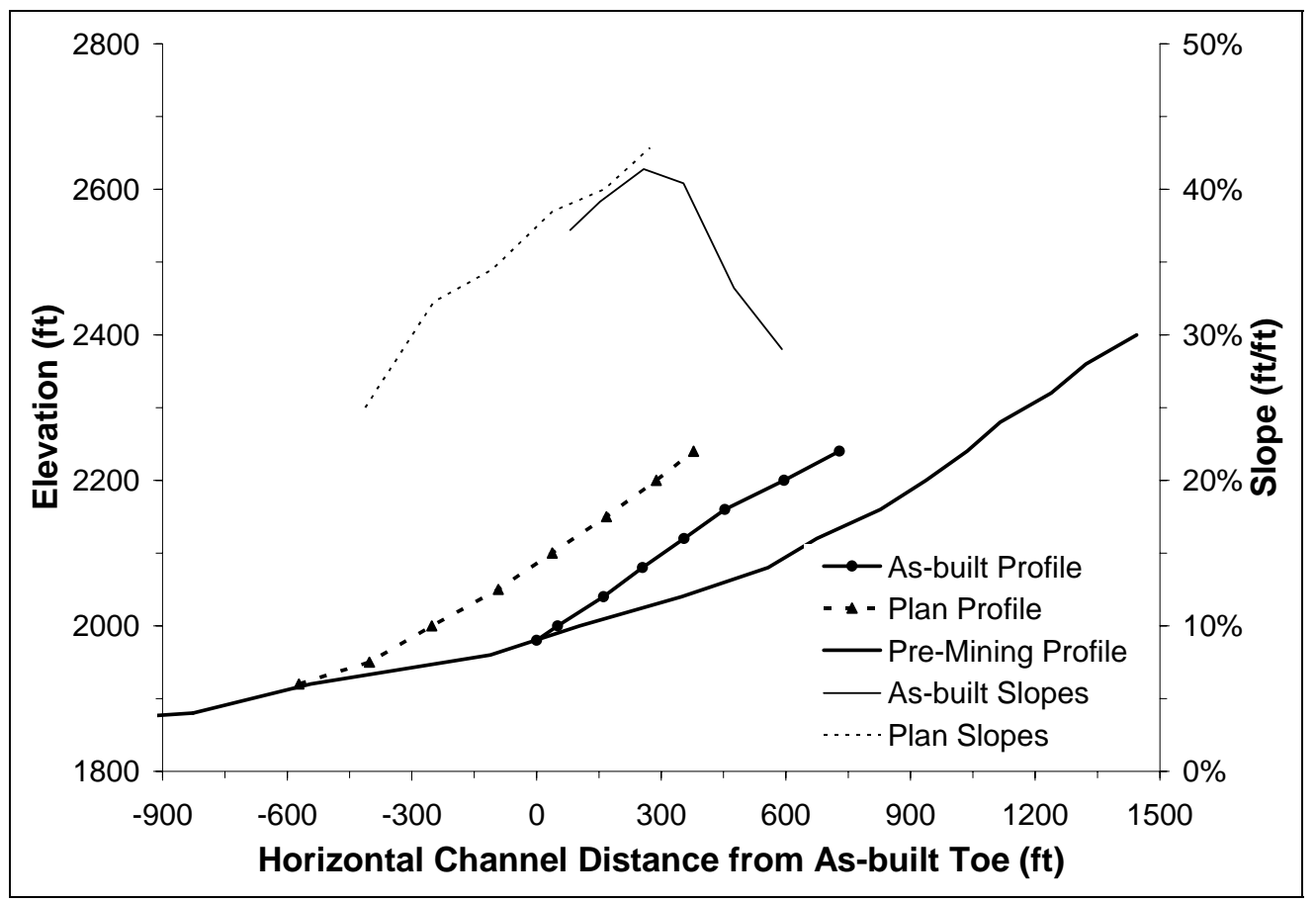

(b)

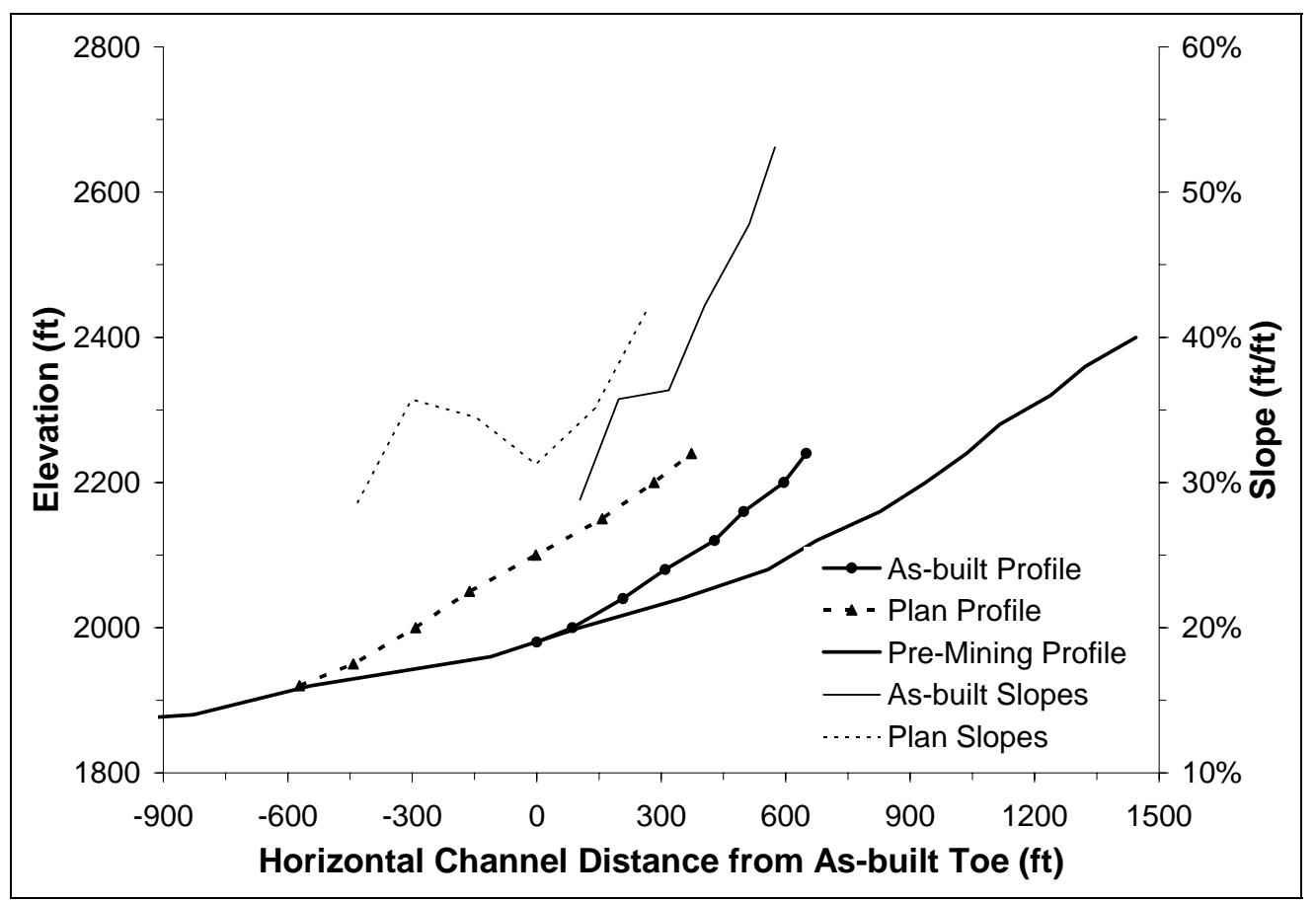

FIGURE 70 - Comparison of Plan and As-Built Longitudinal Groin Ditch Profiles for (a) North and (b) South Groin Ditches of Arches 1 
(a)

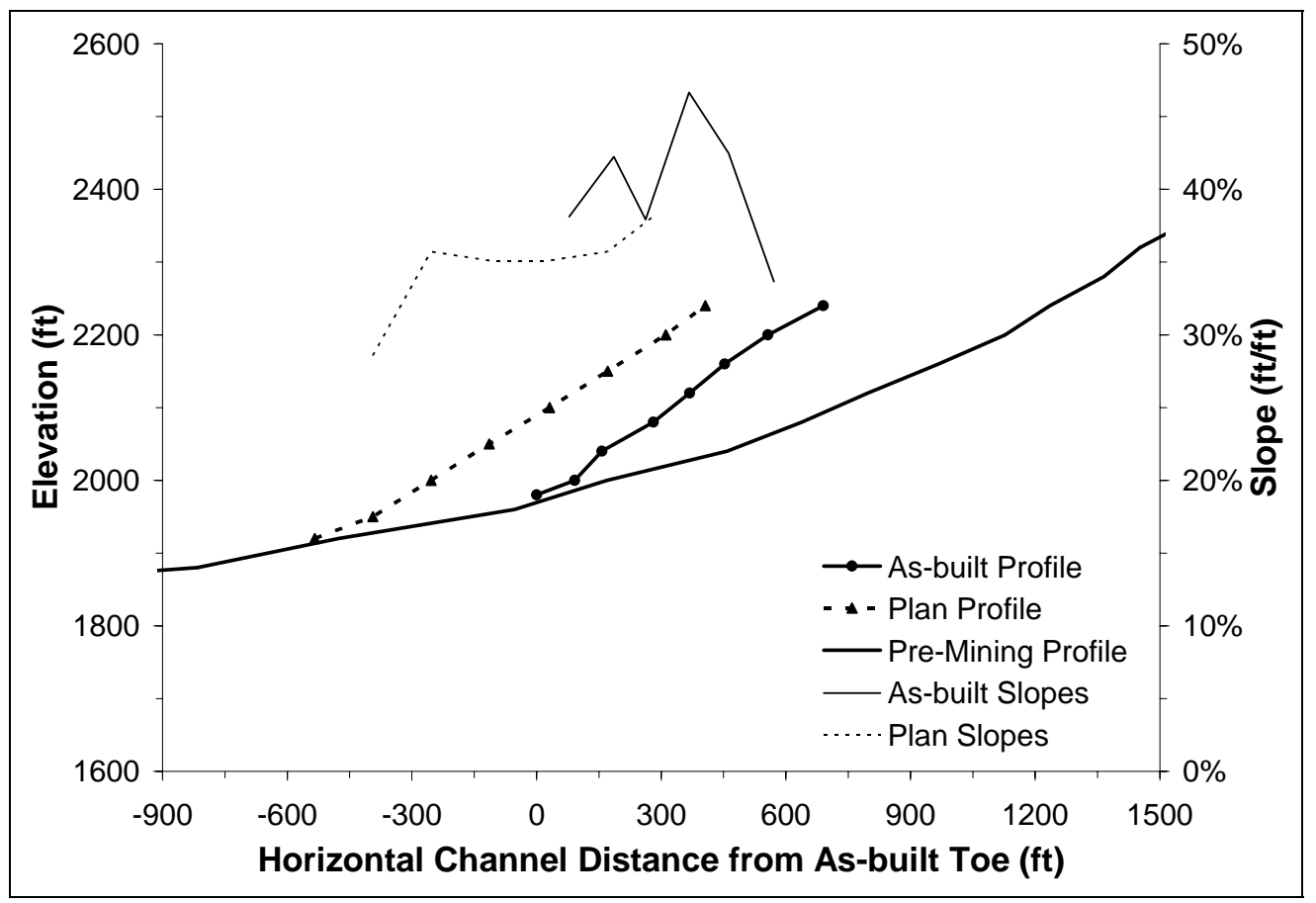

(b)

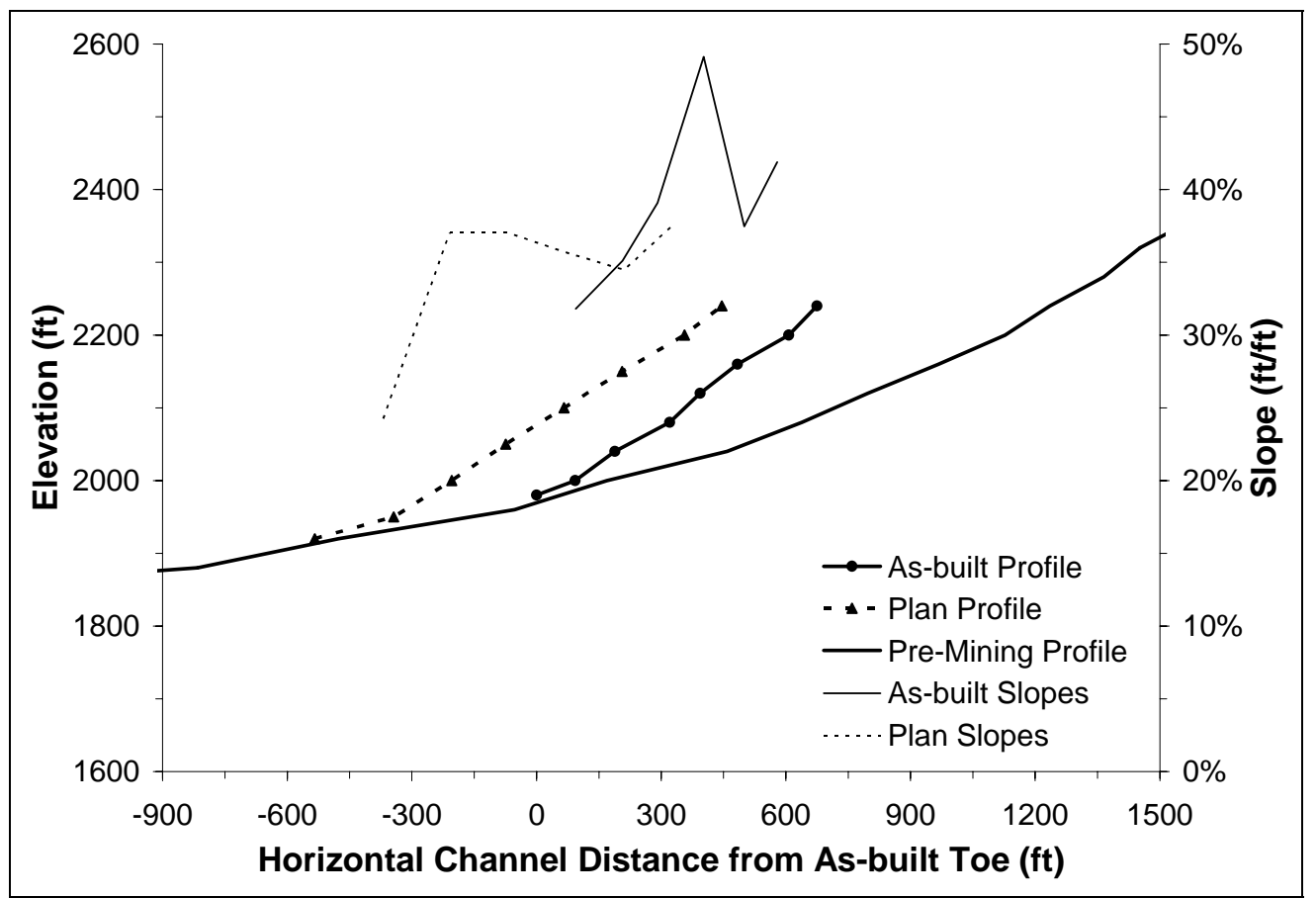

FIGURE 71 - Comparison of Plan and As-Built Longitudinal Groin Ditch Profiles for (a) North and (b) South Groin Ditches of Arches 2 


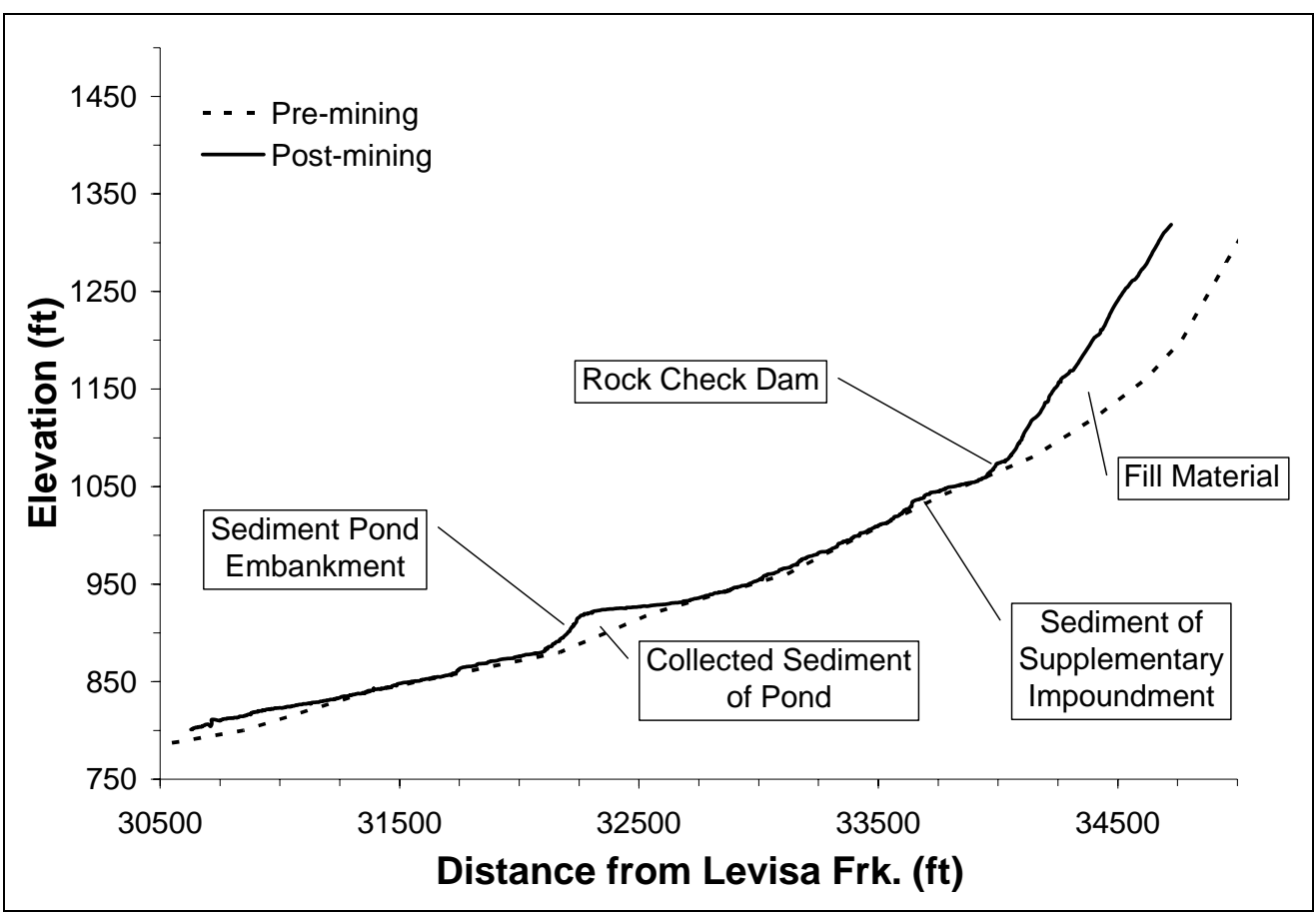

FIGURE 72 - Extent of Post-Mining Longitudinal Stream Survey for HF 11

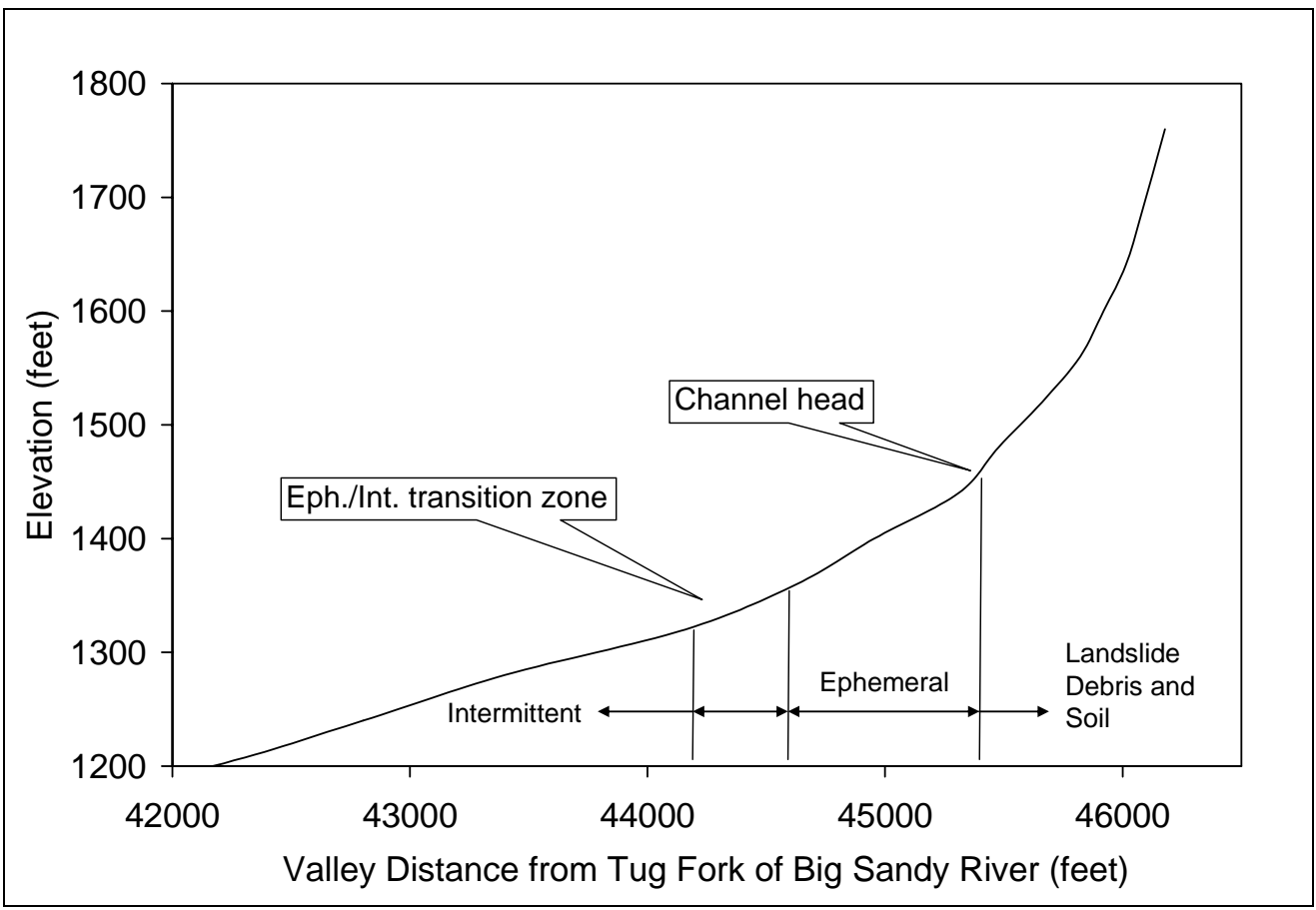

FIGURE 73 - Typical Flow Regime Hydrology of an Appalachian Headwater Stream; Longitudinal Profile from Narrows Branch of Blackberry Fork 
The author, Benjamin David Mater, was born in Louisville, Kentucky on September 3, 1982 and lived in Georgetown, Indiana before attending the University of Louisville. He graduated from Floyd Central High School in May of 2001 and subsequently enrolled in the University of Louisville's Speed School of Engineering in August of the same year.

While attending the Speed School of Engineering, Ben completed all cooperative internship requirements at Fuller, Mossbarger, Scott, and May Engineers, Inc. in addition to the coursework required for Bachelor of Science and Master of Engineering degrees in Civil and Environmental Engireering. Ben graduated from the University of Louisville in December of 2006. 